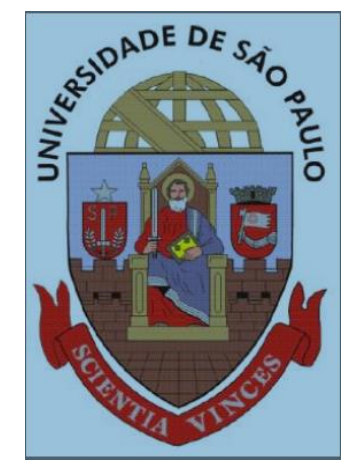

UNIVERSIDADE DE SÃO PAULO

FACULDADE DE FILOSOFIA, LETRAS E CIÊNCIAS HUMANAS DEPARTAMENTO DE LETRAS MODERNAS

PROGRAMA DE PÓS-GRADUAÇÃO EM ESTUDOS LINGUÍSTICOS E LITERÁRIOS EM INGLÊS

Célia Luiza Andrade Prado

A TRADUÇÃO NA ERA VARGAS DE 1930 A 1940

O TARZAN BRASILEIRO DE MANUEL BANDEIRA, MONTEIRO LOBATO E GODOFREDO RANGEL 
UNIVERSIDADE DE SÃO PAULO

FACULDADE DE FILOSOFIA, LETRAS E CIÊNCIAS HUMANAS

DEPARTAMENTO DE LETRAS MODERNAS

PROGRAMA DE PÓS-GRADUAÇÃO EM ESTUDOS LINGUÍSTICOS E

LITERÁRIOS EM INGLÊS

\title{
A TRADUÇÃO NA ERA VARGAS DE 1930 A 1940 \\ O TARZAN BRASILEIRO DE MANUEL BANDEIRA, MONTEIRO \\ LOBATO E GODOFREDO RANGEL
}

Célia Luiza Andrade Prado

\begin{abstract}
Tese apresentada ao Programa de PósGraduação em Estudos Estilísticos e Literários em Inglês, do Departamento de Letras Modernas da Faculdade de Filosofia, Letras e Ciências Humanas da Universidade de São Paulo, para obtenção do título de Doutor em Letras.
\end{abstract}

Orientadora: Prof ${ }^{\mathrm{a}}$ Dr$^{\mathrm{a}}$ Lenita Maria Rimoli Esteves 
PRADO, Célia L. A. A tradução na era Vargas de 1930 a 1940: o Tarzan brasileiro de Manuel Bandeira, Monteiro Lobato e Godofredo Rangel. p. 257. Tese (Doutorado em Estudos Linguísticos e Literários em Inglês) Faculdade de Filosofia, Letras e Ciências Humanas da Universidade de São Paulo.

Área de concentração: Estudos Linguísticos e Literários em Inglês 
Aprovada em:

\section{Banca Examinadora}

Prof $^{a}$ Dr $^{a}$ Lenita Maria Rimoli Esteves (Presidente)

Insituição: Universidade de São Paulo

Julgamento:

Assinatura:

Prof $^{a}$ Dr $^{\mathrm{a}}$ Alzira Leite Vieira Allegro

Instituição: Pontifícia Universidade Católica

Julgamento:

Assinatura:

Prof. Dr. José Garcez Ghiradi

Instituição: Fundação Adminstração Getulio Vargas

Julgamento:

Assinatura:

Prof. Dr. Elias Thomé Saliba

Instituição: Universidade de São Paulo

Assinatura:

Prof. Dr. João Azenha Junior

Insituição: Universidade de São Paulo

Julgamento:

Assinatura: 
Para as meninas que tanto alegram a minha vida, Lela, Lelê e Loli. 


\section{AGRADEÇO}

Muitas pessoas - familiares, amigos, colegas e professores - contribuíram direta e indiretamente para que eu levasse este trabalho a termo. Como a lista é longa, pois longo também é o tempo para se chegar até aqui, citarei aqueles que tiveram ligação direta com ele.

À Prof ${ }^{a}$ Dr ${ }^{a}$ Alzira Leite Vieira Allegro que no século passado, na sala de professores da Cultura Inglesa, me incentivou a enveredar pela carreira acadêmica.

À minha orientadora Prof ${ }^{a} \operatorname{Dr}^{a}$ Lenita Maria Rimoli Esteves que durante uma década, desde meu ingresso no programa de mestrado, sempre se mostrou disponível e pronta a atender aos pedidos de socorro, incentivando, sugerindo e corrigindo com muito humor, carinho e amizade.

Aos Profs. Dr. José Garcez Ghiradi e Dr. João Azenha pela leitura crítica e pelas sugestões no Exame de Qualificação.

Aos colegas desta jornada acadêmica pelas alegrias, solidariedade e ajuda: Dircilene Gonçalves, Zsuzsanna Spiry, Kátia Hanna, Vera Lúcia Ramos, Marly Tooge, Claudia Santana Martins, Ana Julia Perroti-Garcia, Yuri Caribé, Thaís Casson, Lara Souto Santana e em especial Solange Carvalho, consultora de assuntos aleatórios. 
Resumo: Este trabalho tem como objetivo estabelecer o nexo entre a tradução do romance de aventura e o seu contexto, transcendendo o texto e seu valor estético. A tradução envolve uma relação dinâmica entre várias instâncias de práticas culturais. Tais relações demonstram que as obras não acontecem em um vazio e não se pode dissociá-las de seu contexto de produção e recepção. A adoção de obras de literatura de entretenimento como corpus deste estudo, concorda com a abertura às novas temáticas adotadas pela história cultural e revela seu valor para o enriquecimento do discurso historiográfico. Partindo da hipótese de que na prosa as condições de recepção e o momento histórico são fatores decisivos no resultado da tradução e do pressuposto que o gênero literário, além da questão da língua, restringe o caráter autoral e criativo da atividade, o estudo analisou três traduções da série Tarzan, publicadas pela Companhia Editora Nacional na primeira década de 1930: O tesouro de Tarzan, por Manuel Bandeira, Tarzan, o terrível, por Monteiro Lobato e Tarzan, o rei da jângal, por Godofredo Rangel. A partir desse cotejamento se organiza a discussão sobre como o tradutor negocia as condicionantes impostas pelo gênero e pelo contexto e até que ponto a "voz" dos tradutores se manifesta, tendo como arcabouço teórico a história cultural e os estudos da tradução com base, principalmente, a teoria dos polissistemas de Itamar Even-Zohar e a abordagem descritivista da tradução de Gideon Toury, e ainda as discussões de Mona Baker e Theo Hermans sobre a presença do tradutor no texto, buscando suporte também nos paratextos e na palavra dos agentes envolvidos no processo de produção e divulgação do livro a fim de se construir um contínuo entre a tradução e o entorno.

Palavras-chave: tradução, literatura de entretenimento, mercado editorial, formação de público leitor.

\begin{abstract}
The aim of this work is to establish the link between adventure novel translation, in the 1930s, and its production context, going beyond the text and its aesthetic value. Translations involve a dynamic relationship between several frameworks of cultural practices. These relationships show that the works do not take place in a vacuum, and cannot be dissociated from their production and reception contexts. The use of entertaining literature to make the corpus of this study is in accordance to the acceptance of new themes by cultural history and shows its value in the enrichment of historiographical discourse. Starting from the hypothesis that, in prose, reception conditions, and the historical moment are more decisive factors to the resulting translation, and the literary genre imposes constraints that tend to limit the copyright and creative character of the activity, this study analyzed three translations of the Tarzan series, published by Companhia Editora Nacional, during the first decade of 1930: O tesouro de Tarzan, translated by Manuel Bandeira, Tarzan, o terrível, by Monteiro Lobato and Tarzan, o rei da jângal, by Godofredo Rangel. The comparison of these works heads the discussion about how the translator negotiates the constraints imposed by the genre, and by the context, and to what extent the "voice" of the translators is heard. Cultural history and translations studies, primarily, the polysystem theory of Itamar Even-Zohar and the descriptive approach to translation of Gideon Toury, in addition to discussions on the presence of a translator's voice proposed by Mona Baker and Theo Hermans, make up the theoretical framework of this study. The strategies and resources used in the selected translations supported in paratexts and in the word of the agents involved in the production and promotion processes of the book, is considered in order to build a continuum between these translations and their environment.
\end{abstract}

Key words: translation, mass literature, publishing market, new public reader. 


\section{LISTA DE TABELAS}

\section{PÁGINA}

1. Títulos de Tarzan publicados pela Cia. Editora Nacional........................................101

2. Traduções realizadas por Bandeira entre 1930-1940..................................................114

3. Traduções realizadas por Lobato entre 1930-1940..................................................121

4. Traduções realizadas pr Rangel entre 1930-1940...................................................134

5. Quadro comparativo do número de palavras entre originais e tradução ....................164

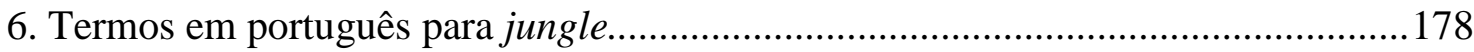

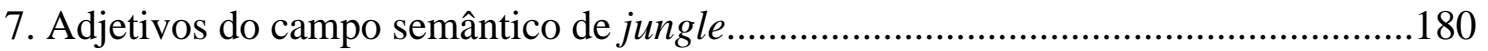

8. Adjetivos em português para o campo semântico de selva.........................................180

9. Termos no TF do campo semântico da fauna.................................................................184

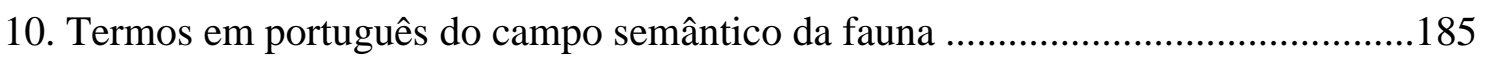

\section{LISTA DE ILUSTRAÇÕES}

FIGURA

PÁGINA

1. Página de um livro de história, publicado pela editora Noite.....................................35

2. Capa de As aventuras maravilhosas de Cap. Corcoran............................................49

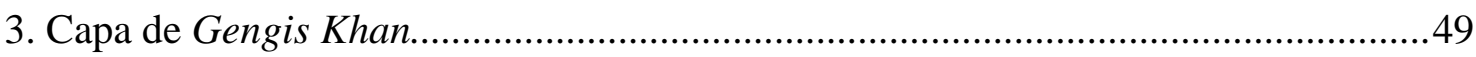

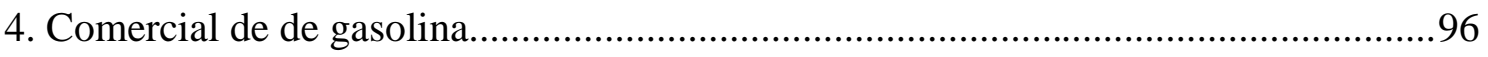




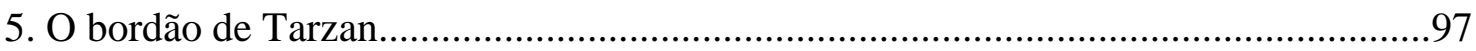

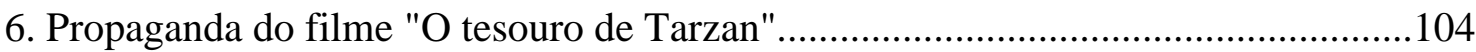

7. Catálogo da Coleção Terramarear de 1934.................................................................139

8. Capas de algumas publicaões da Coleção Terramarear.............................................142

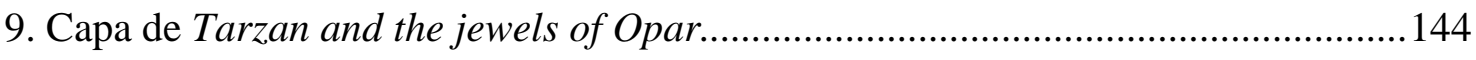

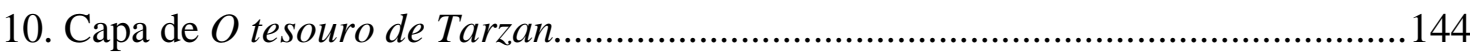

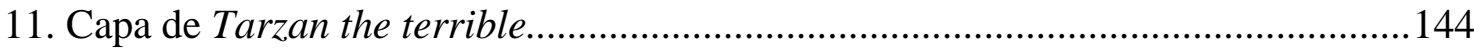

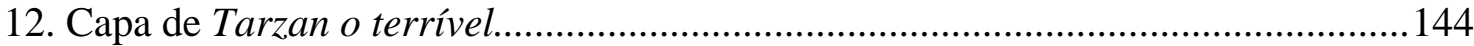

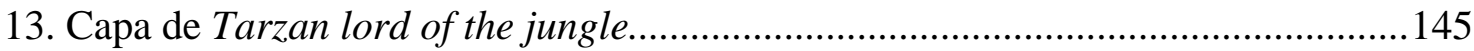

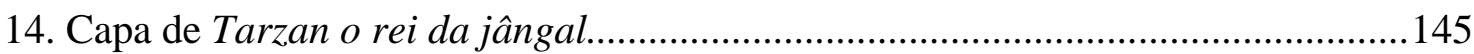

15. Foto de estátua de Hércules e Cacus.........................................................................147

16. Foto de estátua de Hércules e o leão de Neméia.......................................................147

17. Foto de estátua de Hércules e o leão de Neméia.........................................................147

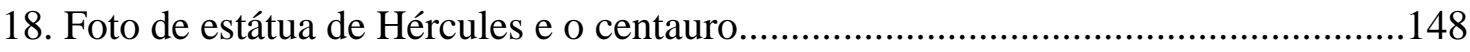

19. Foto de estátua de Hércules e a hidra de Lerna........................................................148

20. Foto de estátua de Hércules e a hidra de Lerna.......................................................148

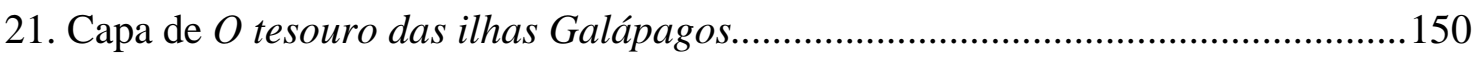

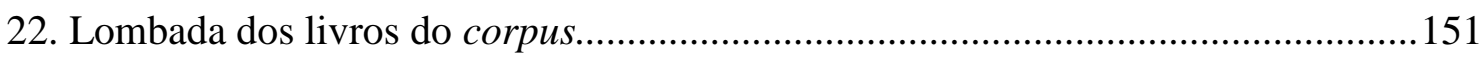

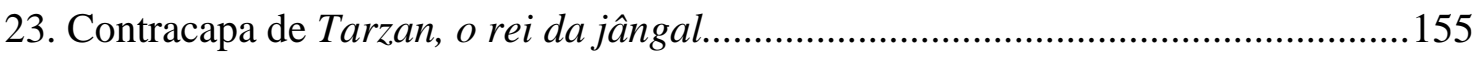

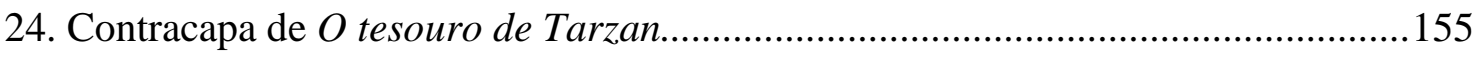

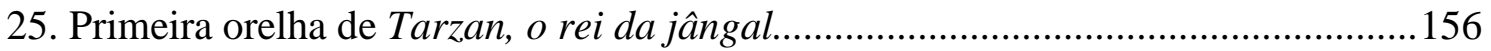

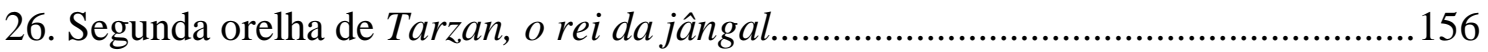

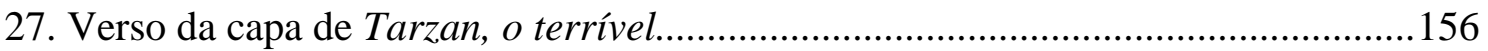

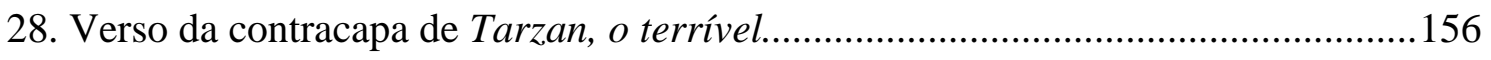

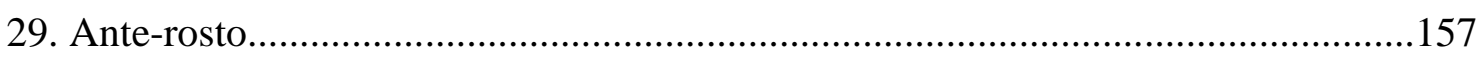

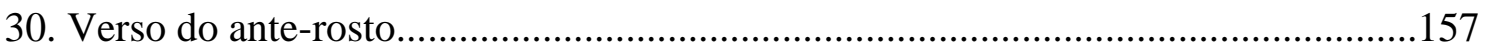

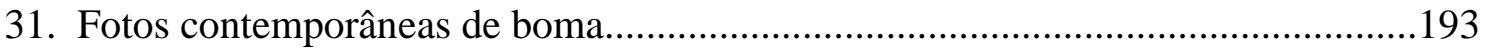

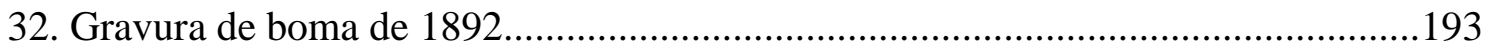

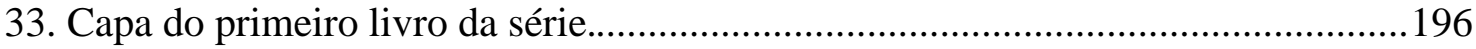

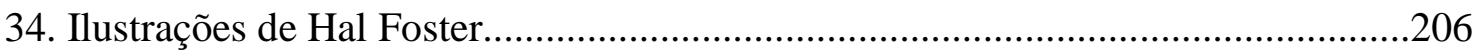




\section{SUMÁRIO}

INTRODUÇÃ

1. O AMBIENTE LITERÁRIO NA ERA VARGAS...............................20

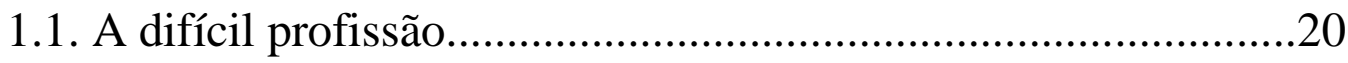

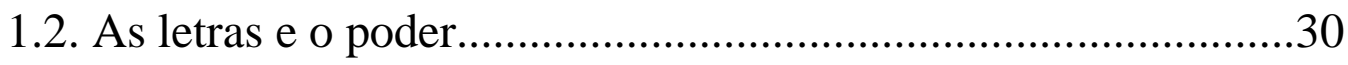

1.3. Identidade cultural e formação da pátria.....................................33

2. A PRODUÇÃO LITERÁRIA NA ERA VARGAS...............................41

2.1. Censura e a indústria livreira....................................................

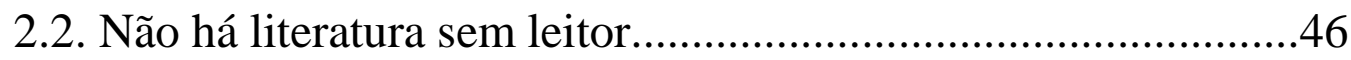

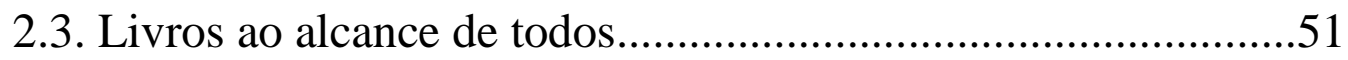

2.4. O mercado da tradução literária..................................................55

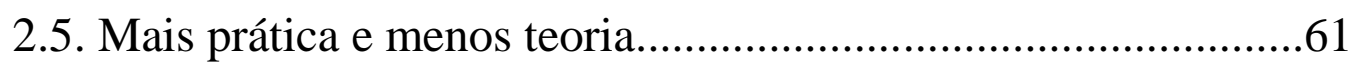

3. PROLEGÔMENO DE CONCEITOS E MÉTODO...............................67

3.1. Romance de aventura e literatura infanto-juvenil.....................67

3.2. Literatura canônica versus literatura de entretenimento.............73

3.3. Texto e contexto na reflexão sobre tradução................................77

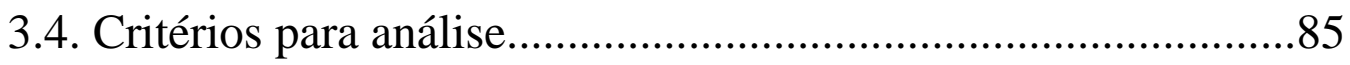


4. O HOMEM-MACACO DE GALHO EM GALHO................................93

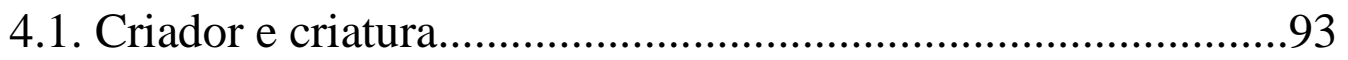

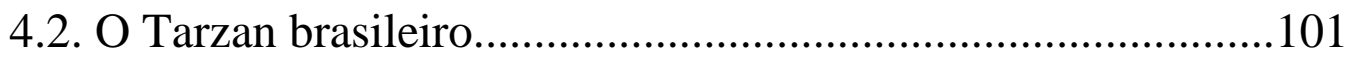

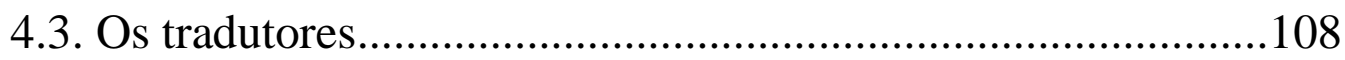

4.3.1. Manuel Bandeira: um tradutor à sombra do poeta..........108

4.3.2. Monteiro Lobato: factótum das letras.............................118

4.3.3. Godofredo Rangel: o amigo escrito.................................128

5. ANÁLISE E DISCUSSÃO DE DADOS.............................................136

5.1. Os epitextos e peritextos...........................................................138

5.1.1. O revestimento do livro...............................................140

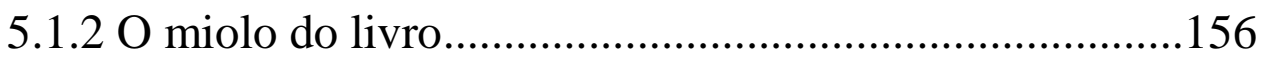

5.1.3. Os intertítulos: anunciadores da narrativa.....................159

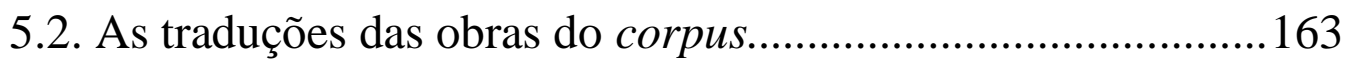

5.2.1. Um trabalho de editoração.............................................163

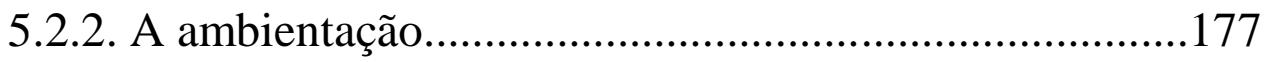

5.2.3. A descrição da ação.....................................................206

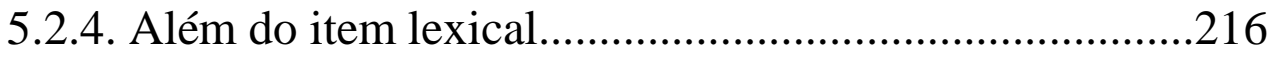

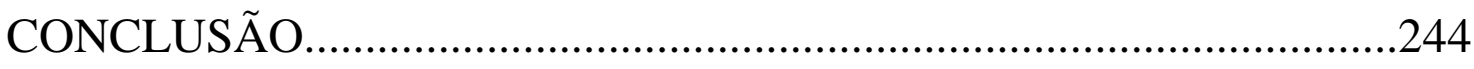

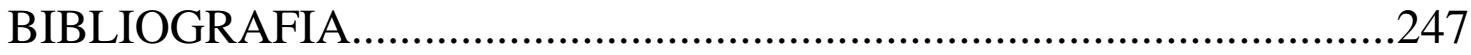




\section{INTRODUÇÃO}

Para o historiógrafo da tradução,

não há uma história, mas

histórias, várias e diversas, da tradução.

Adriana Pagano

Nos anos 1930, a tradução literária era um campo em que poetas, escritores, diplomatas atuavam, tanto por diletantismo como para complementação de renda. Ainda frequente nos dias de hoje, a tradução como atividade paralela era prática comum no passado quando não havia profissionalização na área. Não obstante a contribuição que esses intelectuais deram ao ambiente literário brasileiro por intermédio da tradução, a pesquisa sobre os escritores/tradutores modernistas é pouco contemplada pela academia. A maioria dos estudos esmiúça a atividade de autor desprezando a de tradutor à exceção de trabalhos sobre autores como Érico Veríssimo, Guilherme de Almeida e Monteiro Lobato.

Outros literatos do período, como Manuel Bandeira, Raquel de Queiroz, Carlos Drummond de Andrade e Godofredo Rangel, exerceram o ofício de tradutor, não somente de poesia, mas também de prosa. O levantamento das obras em prosa traduzidas na década de 1930 revelou um panorama instigante: biografias, epistolografia, ensaios e uma profusão de obras de "literatura ligeira": ficção científica, aventura, livros "água-com-açúcar", policiais e de autoajuda. O fato de poetas e escritores prestigiados traduzirem literatura não canônica é intrigante. Qual o motivo que os levava a traduzir esse tipo de literatura? A razão financeira, certamente, concorre para o fato, pois salvo os tradutores diletantes, aqueles que não tiram da tradução seu sustento, os tradutores "profissionais" não têm grande poder de escolha e vários fatores contribuem para a seleção dos títulos: políticas editoriais e mercadológicas, afinidades com as obras e prestígio do tradutor, entre outros. Entretanto, esta seria uma resposta 
muito simplista num período marcado por grandes mudanças que demandam uma investigação mais abrangente.

Assim como a literatura, a tradução envolve uma relação dinâmica entre várias instâncias de práticas culturais. Tais relações demonstram que as obras não acontecem em um vazio e não se pode dissociá-las de seu contexto de produção e recepção. Dessa maneira, transcender o texto e seu valor estético e examinar o nexo entre a produção literária, no caso a traduzida, e a sociedade vai nortear esse questionamento.

Mas, o que para mim revela-se um interessante objeto de estudos, para outros é preterido em detrimento de outras visadas: para a crítica literária parece que com relação a Manuel Bandeira somente sua poética é merecedora de atenção, apesar de o poeta também ter sido cronista competente. Além disso, há restrição quanto ao corpus, pois alega-se que seria uma perda de tempo pesquisar tradução de uma literatura "menor", uma vez que as obras de valor literário, a dramaturgia e a poesia é que seriam dignas de estudo. Isso porque, ainda, perdura uma visão consensual de uma historiografia literária monumental "fortemente valorativa, em que só figuram as grandes obras" (PERRONE-MOISÉS, 1998, p. 23). Os livros de literatura "menor" são renegados pela crítica com argumento de não terem valor estético ou refinamento intelectual. Contudo, mesmo não apresentando valor literário, essas obras interessam por sua dimensão simbólica. O governo de exceção dos anos 1930, reprimindo a produção literária local e implementando um projeto cultural e educacional, acabou por incentivar a publicação de literatura de entretenimento traduzida, o que ocasionou o desenvolvimento da indústria editorial.

Os grandes acontecimentos são marcadores de períodos e mudanças, mas não se mostram suficientes para desvelar elementos que, como em um quebra-cabeça, se juntam para formar o quadro. No Brasil, por exemplo, a maior parte da crítica literária e de arte nasce colada ao Modernismo criando uma espécie de hegemonia, cujo modelo irá se estender pelas décadas seguintes. A Semana de 22 é como um farol que, lançando uma luz tão forte, deixa outros acontecimentos nas sombras. Trata-se do chamado "evento-monstro" ${ }^{1}$, momento catalisador de vários projetos que marca toda uma periodização. O resultado é a geração de uma imagem homogênea do Modernismo, mas que pode ser desmistificada por uma análise da heterogeneidade que se reflete na produção literária e nos papeis assumidos por seus produtores no momento político. É

\footnotetext{
${ }^{1}$ Termo cunhado pelo historiador francês Pierre Nora, na década de 70.
} 
perscrutando a penumbra que se desnuda os aspectos reducionistas da narrativa nacional. A importância da Semana de 22 é inegável, tanto pelos seus aspectos de ruptura com os paradigmas estéticos como pelo seu valor político e social, conforme ressaltados nos compêndios de crítica e história da literatura. Contudo, o modernismo não se resume a ela.

Assim, seguindo o caminho apontado por Lynn Hunt (1989) em A nova história cultural, a pesquisa de certas produções como a troca de correspondência, pelo seu caráter privado e intimista, revela-se uma fonte valiosa para este trabalho que busca indícios fora das "grandes narrativas". Ao recompor os acontecimentos fragmentados do cotidiano, para apreender como estes se expressam no momento histórico, a história cultural deixa de lado as aspirações totalizantes e adota a interpretação de todos os atos humanos, através dos quais se constroem sentidos e identidades. O período histórico das grandes narrativas segue pari passu com a reflexão sobre tradução construída sobre um cânone e ignorando a produção literária considerada menor, ou seja, aquela considerada pela crítica de baixo valor estético e cuja finalidade é o entretenimento.

A adoção de obras de literatura de entretenimento como corpus deste estudo concorda com a abertura às novas temáticas adotadas pela história cultural e revela seu valor para o enriquecimento do discurso historiográfico. Uma vez que "as grandes obras ocorrem tendo como chão e húmus uma cadeia ininterrupta de obras menores" (PERRONE-MOISÉS, 1998, p. 23), essas obras ficcionais não podem ser descartadas. A renovação da historiografia expande o campo disciplinar em uma interação produtiva da qual também se beneficiará a tradução.

A partir dos anos 1990, os Estudos da Tradução sofrem grande influência da teoria cultural. A cultura torna-se a unidade operacional da tradução, deixa de ser a palavra ou o texto, como preconizavam as correntes linguísticas e estruturalistas. Com seu reconhecimento como disciplina, novos métodos, estudos de casos e relações interdisciplinares coerem-se à pesquisa em tradução como recursos importantes na avaliação da maneira como a ideologia influencia diretamente certas estratégias tradutórias. Susan Bassnett e André Lefevère estão entre os primeiros a sugerir a adoção de uma perspectiva cultural na reflexão dos Estudos da Tradução. Esses autores denominaram essa mudança de "virada cultural na tradução" (cultural turn in translation) e sugeriram que o estudo do processo tradutório, combinado com a práxis, poderia oferecer uma maneira de entender a complexidade dessa atividade. Também, 
para esses teóricos, deve-se levar em conta os critérios para avaliar as estratégias utilizadas pelos tradutores e a recepção do texto na cultura alvo.

A "virada cultural" representou uma mudança de paradigma, passando do caráter formalista de estratégia, avaliação e análise do processo tradutório para uma forma mais abrangente de considerá-lo levando em conta questões de ideologia, contexto e história. Com grande capacidade de forjar o desenvolvimento da cultura, a tradução é um complexo processo manipulativo que ocorre em diversos níveis: desde a seleção do texto até questões editorais e de publicação, e é uma forma óbvia de construir imagens e representações.

Assim como a história cultural tem a capacidade de juntar o particular com a totalidade, uma tendência nas pesquisas em tradução é buscar subsídios na microhistória, que é responsável não somente por "uma revisão das questões relacionadas às fontes e aos arquivos, mas também pela redefinição da relação com o passado enquanto diálogo fragmentado" (ADAMO, 2006, p. 82) ${ }^{2}$. A proposição metodológica da microhistória para a tradução baseia-se no recorte temático em um assunto bastante específico, levando ao abandono da certeza na "verdade histórica". Essa maneira de pensar a tradução orientará toda a minha pesquisa.

Muitos dos grandes acontecimentos definem períodos históricos de maneira estanque, contudo, eles não acontecem em um vácuo e a sobreposição de eventos menores faz com que suas fronteiras sejam fluídas e se definam numa relação de causa e efeito. Mesmo ciente dessa arbitrariedade da periodização histórica, fez-se necessário um recorte temático/temporal no trabalho. Assim, para fins de pesquisa, foi definida a década entre 1930 e 1940 como o período no Brasil a ser estudado, pois é fortemente marcado por mudanças políticas, sociais e culturais, coincidindo com o Estado Novo, quando há tanto repressão e censura como uma interdependência produtiva entre a inteligência e o poder.

Trata-se, talvez, do momento mais importante para a cultura brasileira, deflagrado pelo Modernismo, quando "as obras literárias esclarecem, tanto ou mais do que os discursos políticos, como são construídos os conceitos de nação e de identidade nacional" (PERRONE-MOISÉS, 2007, p. 18) e singularizado pela ascensão ao governo por Getúlio Vargas, que rompendo a hegemonia da Velha República, conduz o país por novos caminhos, por bem e por mal. Dentre os escritores/tradutores, alguns são mais

\footnotetext{
${ }^{2}$ A rethinking of issues regarding sources and archives, but also a redefinition of the relationship with the past as a fragmentary dialogue.
} 
engajados na política que outros, no entanto, todos são representantes importantes da intelectualidade da época.

Apesar do impressionante volume de obras em prosa traduzida, os comentários, resenhas e críticas da época se debruçam sobre a tradução lírica. Também, contemporaneamente, os trabalhos enfatizam a tradução de poesia, o que não surpreende, sendo os poetas modernistas consagrados e donos de uma produção poética admirável. Um exemplo é a tese de doutoramento de Jorge Wanderley, A tradução do poema entre poetas do Modernismo: Bandeira, Guilherme de Almeida, Abgar Renault, PUC-RJ (1988) que segundo o resumo, tem como objetivo "procurar a partir da atividade dos poetas enquanto tradutores, novos subsídios para o delineamento de seus perfis, seus grupos, sua época, as relações existentes entre todos esses elementos". Alguns teorizam sobre um movimento de influência recíproca entre a lírica dos poetas e as obras por eles traduzidas, como faz Alfredo Bosi (2002) com relação a Manuel Bandeira.

Talvez isso se deva ao fato de que na tradução de poesia alguns aspectos específicos da poética se evidenciam muito devido à congenialidade das duas atividades, que envolve criação e recriação. Na prosa, o gênero literário, as condições de recepção e produção, e o momento histórico concorrem para o resultado da tradução. Há, na área dos estudos da tradução, algumas abordagens que buscam o estilo do tradutor, muitas vezes recorrendo à linguística de corpus. Mona Baker (2000), por exemplo, considerando a tradução como ato criativo, acredita que o tradutor não estaria simplesmente "reproduzindo" o que está no texto fonte e que forçosamente deixará sua "impressão digital" (thumb-print) no decorrer do texto. Mas, considerando que o ato tradutório não se limita à simples transposição de um sistema linguístico a outro e está relacionado a demais fatores como as condições de produção e publicação da obra, o gênero, a ideologia tanto do autor quanto do tradutor, evidencia-se a necessidade de uma metodologia de análise que transcenda as vertentes clássicas da linguística e da estilística, que muitas vezes resulta em dicotomias de juízo de valor como fiel/infiel, literal/livre, original/cópia, remetendo à sacralização do original.

Partindo dessa perspectiva, deixa-se de priorizar o referencial do original e surge a necessidade de transcender o texto por meio de uma reflexão historicista apontada por Bassnett e Lefevere (1990, p. 26), "A língua não é problema, ideologia e poética sim; 
como também o são os elementos culturais que não são imediatamente perceptíveis [...]" 3

A consideração do livro como um ato de fala impresso, como defende Bakhtin, impõe uma nova apreensão do fato literário no qual, segundo Dominique Maingueneau (2005, p. 7): "o dito e o dizer, o texto e o contexto, são indissociáveis". Na Análise do Discurso, estilo adquire uma dimensão textual e discursiva, estando relacionado ao gênero, à dicção e ao contexto de produção. Os gêneros da prosa são contaminações de formas pluriestilísticas (paródia, estilização, heteroglossia), contrariando uma certa noção de purismo da tipologia tradicional. A tradução potencializa o caráter dialógico da prosa, conferindo ao discurso uma forma enunciativa que depende muito mais do contexto comunicativo e da cultura do que da própria palavra (MACHADO, 2005, p. 158). Nessa perspectiva, o tradutor estará mais sujeito a imposições do "contexto comunicativo", do momento histórico e da cultura, do que da sujeição à língua. No entanto, isso não quer dizer que a obra traduzida seja totalmente determinada pelo momento histórico, sendo antes o resultado da combinação entre fatores contextuais e da estética criativa do autor/tradutor. Na tradução estão em jogo a voz do autor e a voz do tradutor, informadas pelos seus respectivos contextos.

Para Gideon Toury (2003, p. 200-02), também, a tradução literária é uma atividade de "dimensão sociocultural”, pois envolve duas línguas, duas culturas e duas tradições literárias. Toury advoga que a sociedade é regida por várias normas, que podem até mesmo ser conflitantes, mas estão interrelacionadas. Tais normas operam em todos os estágios do processo tradutório. Elas são o conceito-chave e o foco para se determinar a relevância social de uma atividade, porque são os fatores principais de estabelecimento e manutenção da ordem social. Toury fornece não somente a definição de normas, mas, também, uma metodologia para a avaliação da tradução.

Partindo desses pressupostos, o trabalho se propõe a examinar, à luz da teoria de Toury sobre as normas e das discussões de Mona Baker e Theo Hermans sobre a presença da voz do tradutor, as estratégias e os recursos utilizados nas traduções selecionadas, buscando suporte também nos paratextos, na palavra dos agentes envolvidos no processo de produção e divulgação do livro a fim de se construir um contínuo entre a tradução e o seu entorno. Pois, como observa Adriana Pagano (2001,

\footnotetext{
${ }^{3}$ Language is not a problem. Ideology and poetics are, as are the cultural elements that are not immediately clear [...]
} 
p.120), a historiografia da tradução é "o estudo histórico e crítico da tradução sob a perspectiva de sua historicidade, isto é, de sua inserção num contexto histórico".

Seguindo o pensamento de Lieven D'Hulst (2001), Jenny Williams e Andrew Chesterman (2002), a historiografia não se limita a compilar dados, o estudo requer que eles sejam submetidos a um questionamento e a uma reflexão que apontem para mais de um caminho a ser percorrido, buscando tradutores e obras esquecidas, evitando reduções. Para John Milton (2002, p. 14), "existe uma grande lacuna no Brasil, nessa área, um país onde há grande disposição para se adotarem modelos estrangeiros, mas pouca vontade e interesse para se fazer o trabalho básico de pesquisar arquivos". Um dos motivos pode advir da dificuldade na pesquisa.

Parece ser consenso entre autores brasileiros que os trabalhos historiográficos da tradução são incipientes por três fatores principais: 1) a falta de organização, 2) a escassez de documentação e 3) o desprestígio que goza a atividade tradutória no Brasil, que ainda hoje carrega o estigma da inferioridade e da invisibilidade do tradutor. Paes (1990, p. 9) afirma que "quem se propuser algum dia a escrever a história da tradução literária no Brasil terá certamente de enfrentar as mesmas dificuldades encontradas pelos demais pesquisadores do nosso passado ou do nosso presente menos imediato". As dificuldades ele credita ao pequeno número de bibliotecas, ao acervo reduzido e à deficiência na sua catalogação.

Wyler (2003, p. 24) relata sua experiência:

Quando me dispus a estudar a história da tradução no Brasil impressionou-me de imediato a escassa biografia existente sobre o assunto nos bancos de dados do $\mathrm{CNPq}$ e nos fichários das bibliotecas. Encontrei páginas e páginas sobre o desenvolvimento da tradução na Europa [...] mas praticamente nenhuma informação sobre o que ocorre ou ocorreu em nosso país.

A esse problema acrescente-se que mesmo fontes fidedignas cometem deslizes. Por exemplo, na página oficial da Fundação Casa de Rui Barbosa consta que Bandeira traduziu o poema Mireille, mas atribui a autoria a Gabriela Mistral. Na realidade, tratase de um longo poema provençal do prêmio Nobel Frédéric Mistral, editado pela Delta, em 1962. Bandeira traduziu sim a poetisa chilena, mas são dois sonetos incluídos no volume Poemas traduzidos: "O pensador de Rodin" e "Primeiro soneto da morte". Outro deslize dessa fundação é atribuir a autoria de Minha cama não foi de rosas a Orson Wells, quando, na realidade, se trata de um diário de uma prostituta anônima identificada pelas iniciais O.W. e compilado por Marjorie E. Smith. John Milton (2002, 
p.93), em $O$ clube do livro e a tradução relata que foi na década de 1950 que a Companhia Editora Nacional lançou as coleções Terramarear e Paratodos, mas foram localizados exemplares dessas coleções datados da década de 30. Wanderley (1988, p. 24) afirma que "cabe lembrar que o poeta traduziu cerca de cinquenta ${ }^{4}$ livros em prosa, para editoras diversas" não fornecendo uma lista dos títulos. Contrariando Wanderley, a pesquisa localizou um total de trinta e oito títulos entre prosa, poesia e dramaturgia, enquanto que a Casa de Rui Barbosa relaciona somente catorze.

Milton (1993, p. 174) observa que "muito pouco foi escrito em termos de uma abordagem histórica ou descritiva da tradução literária no Brasil” e José Paulo Paes (1990, p. 9), também, reitera a “escassa atenção à atividade dos tradutores". Para Wanderley (1988, p. 2), "uma hipotética história da tradução de poesia no Brasil a partir do modernismo, começa, pois, por algum espontaneísmo, a experiência de amador, o caráter dominical e menor da poética", prenunciando as dificuldades que o pesquisador poderá encontrar pela falta de comentários e registros sobre a atividade. Considerando essa lacuna, este trabalho se justifica na medida em que vários autores assinalam a carência de pesquisa na área de historiografia da tradução no Brasil.

Além de se tornar oportuno porque a partir do mapeamento da atividade tradutória de literatura ligeira poderemos resgatar o papel da tradução em sua relação com o momento histórico, o estudo demonstra como qualquer tipo de obra literária, pelo seu papel na formação de um novo público leitor, concorrendo para redimensionar o papel dos escritores/tradutores brasileiros. Vale, oportunamente, ressaltar que a definição de literatura é motivo de debate, pois muitos são os fatores que privilegiam as obras, variando conforme o momento histórico. A crítica literária, ao eleger falar de certos escritores em detrimento de outros, "estabelece sua própria tradição e, de certa maneira, reescreve a história literária" (PERRONE-MOISÉS, 1998, p.11). Contudo, não se pode desprezar a importância de certas publicações dirigidas a uma ampla gama de leitores, representados por um público consumidor não elitizado, principalmente nos centros urbanos. Ciente da arbitrariedade da categorização, o presente trabalho adota o termo "literatura ligeira" e "literatura de entretenimento" para aquelas obras que buscavam atingir um público menos letrado, mas que nem por isso são menos reveladoras de um período.

\footnotetext{
${ }^{4}$ Grifo meu.
} 
O corpus do estudo é composto de três livros da série Tarzan em português. apesar de o gênero ser desconsiderado pela crítica, seus tradutores eram escritores, poetas, enfim, intelectuais de renome. Um volume da série foi traduzido por Manuel Bandeira e dois outros, um Monteiro Lobato e outro por Godofredo Rangel, todos publicados nos anos 1930.

Segundo algumas vertentes da crítica literária, as obras de literatura ligeira, aqui analisadas, não poderiam ser consideradas isoladamente, como um produto literário per se por não apresentar um valor estético. No entanto, são obras representativas de um momento histórico e foram importantes na formação de um público leitor e, por isso, são merecedoras de atenção. As considerações de Alessandra El Far sobre a literatura direcionada "a uma massa irrestrita de leitores", no século 19, continuam valendo para o século seguinte:

Como parte integrante de um quadro cultural bem mais amplo, esse conjunto de textos pode ser melhor compreendido diante do cenário de sua produção. Ao intercalar "texto" e "contexto" [...] o que até então parecia estranho, exótico ou despropositado passa a exibir um conjunto viável de significados e explicações (EL FAR, 2004, p. 18).

Inegavelmente, o primeiro governo de Getúlio Vargas foi um período paradoxal, marcado por grandes mudanças políticas, econômicas, sociais, tanto positivas quanto negativas, que resiste à análise simplista e reducionista. Dentre os vários fatores que contribuíram para a expansão do mercado editorial nos anos 1930, destacam-se a reforma educacional, a censura e a configuração de uma sociedade mais urbana, criando a necessidade de publicar obras direcionadas a um público fora do círculo das elites. Apesar de o desenvolvimento editorial, principalmente na capital, ter se iniciado no final do Segundo Império, impulsionado pela imigração, consolidação da imprensa e pela abolição, é nos anos 1930 que se consolida a indústria livreira, com a modernização das editoras e melhoria na distribuição e busca da ampliação do público leitor.

Este trabalho pretende contribuir para a história da tradução no Brasil e levar a uma reflexão sobre o papel da tradução no século passado e sua intersecção entre o momento político, o cultural e o literário, considerando-os aspectos definidores no desenvolvimento da tradução literária. O resgate das traduções de literatura ligeira, no período Vargas, poderá lançar uma nova luz sobre os estudos da tradução no Brasil e sobre escritores/tradutores negligenciados pela historiografia. Com relação à estrutura do trabalho, ele parte do âmbito geral, o contexto, e vai se estreitando gradativamente 
até o específico, as análises das traduções, sem perder de vista a relação entre os tradutores e o seu meio e seu tempo, relação esta confirmada pelas palavras de Manuel Bandeira:

Ora, estou convencido de que homem nenhum pode ser inatual, por mais força que faça. O vocabulário, a sintaxe podem ser inatuais: as formas de sentir e pensar, não. Somos duplamente prisioneiros: de nós mesmos e do tempo em que vivemos (BANDEIRA, 1966, p. 120).

$\mathrm{Na}$ confluência do momento histórico com a tradução, este estudo leva em conta as práticas culturais, com foco no meio literário, considerando a literatura enquanto produção e recepção. Pois, conforme defende Wyler:

A historiografia da tradução é uma área do conhecimento híbrida, dado que não aborda apenas as traduções em si, mas as circunstâncias que cercaram sua produção em cada período e em cada país, todas muito diferentes entre si. Disso decorre que, se quisermos realizar pesquisas confiáveis, teremos de nos voltar para o conhecimento da história de nosso país e para a aquisição da metodologia que é própria dessa ciência. Sem esse instrumental, corremos o risco de ficar nos repetindo uns aos outros ou de cairmos em ciladas evitáveis (WYLER, 2005, p. 109).

É à luz dessa percepção que o Capítulo 1 examinará o ambiente literário durante o período denominado Era Vargas e a relação dos intelectuais da época com a política de Estado. Também verificará de que maneira o Modernismo concorreu com a ideologia de Estado na construção da identidade nacional. O Capítulo 2 discutirá a produção literária na Era Vargas e a extensão da influência da censura na indústria livreira, com foco na Companhia Editora Nacional, para quem Manuel Bandeira mais traduziu. O fenômeno editorial de lançamento das coleções e séries, em sua maioria de obras traduzidas, será discutido com relação à formação de um novo público leitor e sua relevância para o momento histórico. Esse capítulo, também, pretende apresentar um panorama sobre a tradução nesse período e os conceitos vigentes que regem o processo tradutório tendo nas correspondências, crônicas e paratextos as fontes principais, uma vez que não foi localizada nenhuma teorização sistemática a esse respeito realizada pelos tradutores dessa época. Tendo sido estabelecido o quadro contextual, no capítulo 3 serão discutidas as teorias que embasam o estudo e a metodologia utilizada no desenvolvimento da tese. O capítulo 4 fará uma breve introdução sobre a criação de Tarzan e seu autor, Edgar Rice Burroughs, e apresentará os tradutores, Manuel Bandeira, Monteiro Lobato e Godofredo Rangel. 
Partindo da hipótese de que na prosa as condições de recepção e o momento histórico são fatores influenciam o resultado da tradução e de que o gênero literário impõe condicionantes que tendem a limitar o caráter autoral e criativo da atividade, o capítulo 5 analisará três traduções da série Tarzan, publicadas pela Companhia Editora Nacional na primeira década de 1930: O tesouro de Tarzan, por Manuel Bandeira, Tarzan, o terrível, por Monteiro Lobato e Tarzan, o rei da jângal, por Godofredo Rangel sempre tendo os originais como referência. A partir desse cotejamento se organizará a discussão sobre como o tradutor negocia as condicionantes impostas pelo gênero, e pelo contexto, e até que ponto a "voz" dos tradutores se manifesta.

Por fim, a conclusão e a bibliografia fazem o fechamento do estudo. Vale ressaltar que as citações em inglês são traduções minhas. Com relação às citações em português, decidiu-se por não atualizar a ortografia original, buscando refletir a transitoriedade cultural da década de 1930 marcada por diversas mudanças ortográficas. 


\title{
1. O AMBIENTE LITERÁRIO NA ERA VARGAS
}

\author{
A partir da revolução de 1930 \\ começou a chamada Era Vargas, \\ assim conhecida por ser o tempo \\ de construção e consolidação da \\ figura de sua liderança máxima, \\ Getúlio Vargas. \\ Angela de Castro Gomes ${ }^{5}$
}

\subsection{A difícil profissão}

O Modernismo no Brasil, que teve na Semana de 22 o seu evento inaugural, apresentou uma abrangência e uma importância que influenciou todas as artes. $\mathrm{O}$ termo modernismo engloba três aspectos: um movimento, uma estética e um período, o qual pode ser estabelecido de maneira geral entre 1922 e 1945 (CANDIDO; CASTELLO, 2006, p. 9). O período apresenta um quadro de rarefação cultural com um público consumidor restrito de cultura elitista herdado das décadas anteriores, sendo o analfabetismo um fator de grande pertinência nesse cenário. Se no século 19 o número de não alfabetizados passava dos $70 \%$ da população, quase na metade do século 20 essa taxa, apesar de decrescer, ainda aponta para uma maioria de analfabetos, chegando a $57 \%$ (WYLER, 2003, p.110) ${ }^{6}$.

Acrescente-se ao problema do número de iletrados, as precárias condições de produção e de distribuição de livros, o difícil acesso às livrarias, as quais se restringiam quase exclusivamente aos grandes centros, principalmente, Rio de Janeiro e São Paulo, tudo isso contribuindo para o pequeno número de consumidores de literatura. $\mathrm{Na}$

\footnotetext{
${ }^{5}$ In: "As marcas do período". http://historia.fundacionmapfre.org/historia/pt/images/BRA 04_CLAVES tcm245-32473.pdf

${ }^{6}$ No censo de 1872, a população do Rio de Janeiro era de 522 mil hab. com 57,0\% dos homens e 43,8\% das mulheres alfabetizados. Em 1906, numa população de 811.443, avalia-se que 400 mil sabiam ler (EL FAR, 2004, p. 13).
} 
primeira década do século 20, o país contava com um máximo de 40 livrarias. Em São Paulo havia "uma meia dúzia de livrarias mal arrumadas e desertas", conforme relata Monteiro Lobato ${ }^{7}$. Na década de 1930, não só a taxa de anafalbetismo era de aproximadamente de $70 \%$, como em torno de $20 \%$ a $25 \%$ dos alfabetizados não tinham o hábito da leitura e nem liam jornais (DUTRA, 2013, P. 230).

As mudanças nesse panorama cultural foram lentas, conforme observa Hélio de Seixas Guimarães (2004, p. 67): "As pequenas tiragens, a lentidão do consumo dos livros e as limitações do público leitor não são, no Brasil, exclusividade do século 19 e, em proporções diferentes, mantém-se ainda hoje". Mas, apesar de a difusão da leitura nos nossos dias ainda deixar a desejar, há fatores que contribuíram para a mudança do quadro, cujo primeiro impulso se deu no governo Vargas - a profissionalização de trabalhadores, a tecnologia, os meios de difusão e distribuição e o aumento do público leitor decorrente da universalização do ensino -, e que são elementos distintivos da época contemporânea.

Ainda com relação ao século 19, Lajolo (2004, p. 99) observa que "naqueles idos [século 19], mecenato e mercado coexistiam como alternativas para o escritor", sendo tempos especialmente difíceis para o escritor desconhecido. Mesmo aqueles já renomados sofriam nas mãos dos editores. Louis Garnier, conhecido livreiro carioca, por exemplo, só publicava aqueles autores já consagrados, como Machado de Assis, e "em diversos relatos de época, encontram-se menções ao caráter metódico e sovina do editor, aos contratos injustos fechados com os literatos, e até à sua mania de tudo economizar" (EL FAR, 2004, p. 39).

No início do século 20, a crescente urbanização, que se iniciou com a República, resultaria em um cenário promissor para o Rio de Janeiro, transformando a capital no maior centro comercial do país. Animados com os novos tempos, os livreiros viam o potencial de expansão da atividade. No entanto, a realidade não correspondia à expectativa e o desenvolvimento do mercado editorial não era generalizado nem linear, alternando momentos de retração e crescimento. Fato comum eram os "empreendimentos financiados pelos próprios autores ou por seus mecenas", observa Sérgio Miceli (2001, p. 97) e cita como exemplos a primeira edição do Juca Mulato, de Menotti Del Picchia, a primeira edição de oitocentos exemplares de Losango Cáqui, de

\footnotetext{
${ }^{7}$ Entrevista para Vamos Ler, RJ, 30/09/1943. p. 26-27 (Apud LIMA, 1985, p. 45).
} 
Mário de Andrade e a edição parisiense de Pau-brasil, de Oswald de Andrade, todas financiadas pelos seus autores.

Diante da dificuldade de publicação, muitos dos jovens intelectuais recorriam às revistas para ter a sua obra divulgada, sendo que alguns deles participaram da fundação delas. A importância desse meio impresso é observada por Yone Soares de Lima (1985, p. 19):

Assim, da mesma forma que a revista da época despertava para uma consciência intelectual, vinha suprir do que mais se ressentia a literatura emergente, isto é, de uma editoração nacional acessível, fato que só se tornou realidade com a atuação pioneira de Monteiro Lobato.

Após a Semana de Arte Moderna, os modernistas, criam a revista Klaxon, que além de veículo de propagação do movimento, publicava excertos de obras e anunciavam o seu lançamento pela "Editora Klaxon", que na realidade não era um empreendimento estruturado nos moldes de editora, mas somente um selo que chancelava publicações bancadas pelos próprios autores.

Nos anos 1930, o custeio da edição de obras pelos autores diminui devido às transformações no plano econômico, social, político e cultural e à expansão da rede de instituições culturais públicas, mesmo assim ainda persiste. Hallewell (1985, p. 250) relata:

O fato de haver no livro o nome de um editor não exclui a possibilidade de que o próprio autor tenha assumido os custos da edição. Manuel Bandeira, por exemplo, pagou todas as edições de seus poemas até 1940. Alguns nomes de editoras chegavam a ser fictícios, inventados pelo autor para aumentar as chances de venda de seu livro, como Edições Pindorama, cujo nome era utilizado por diversos poetas de Belo Horizonte.

A melhoria do mercado editorial apresentou-se insuficiente e a situação continuou desfavorável para a maioria dos escritores nacionais. O leitor que consumia literatura pertencia à própria elite intelectual que a produzia, ou seja, um pequeno mercado consumidor. Graciliano Ramos, em entrevista a Ernesto Luiz Maia, reproduzida em recente matéria sobre o autor, ensaia uma explicação:

Acho que as massas, as camadas populares, não foram atingidas e que nossos escritores só alcançaram o pequeno burguês. Por quê? Porque a massa é muito nebulosa, é difícil interpretá-la, saber de que ela gosta. [...] Talvez seja isso 
mesmo: talvez porque um escritor não sente os problemas como o povo, este não o deixe penetrar nele. ${ }^{8}$

Um trecho de uma carta de Manuel Bandeira a Mário de Andrade mostra como as obras circulavam dentro do círculo literário: "Você me pergunta quais os seus livros que não tenho em minhas estantes. São os que emprestei ao Vignale: Cáqui e Clã do jabuti. [...] Falta também Macunaíma, mas esse está emprestado ao Rodrigo" 9 . A prática corrente de se emprestar obras subtraía do autor o provento vindo das vendas, que já não era significativa devido ao público leitor restrito e ao fato de a maior porcentagem da renda caber ao editor.

A disputa pelo reconhecimento da crítica e pela aceitação por parte de um público maior levava à formação de cotteries, gerando conflitos que alimentavam ainda mais o elitismo. O momento de grande polarização política alimentava as divergências:

Enquanto os escritores vinculados ao perrepismo ${ }^{10}$ buscaram colocar suas obras a serviço de uma ideologia "nacionalista" da qual poderiam utilizar os grupos dirigentes, [...] o grupo de intelectuais "democráticos" sob a liderança de Mário de Andrade se empenhou em não deixar que suas tomadas de posição no terreno político-partidário pudessem comprometer o conteúdo de sua produção literária e estética (MICELI, 2001, p. 103).

Exemplos de cisão entre os intelectuais com o acirramento da polarização ideológica se encontram na correspondência entre Manuel Bandeira e Mário de Andrade. De certa feita, Bandeira assim critica o escritor e jornalista sergipano Genolino Amado: "O que me irrita neste momento é que quando um sujeito de esquerda não simpatiza com outro diz que ele é fascista ou pelo menos indiferente ou torre de marfim, etc". ${ }^{11}$ Com relação ao policiamento político de Plínio Salgado, Bandeira é mais contundente e critica a atividade literária do grupo integralista, a seu ver engajada e sem estilo:

O trabalho de material de escrever o artigo não é grande, em duas horas o faço e ao correr da pena, mas enquanto não escreveo os nervos trabalham, fico apreensivo de dizer bobagens: já se foi o tempo em que se podia alinhar frases bonitas ou bestialógicos no gênero da Legião Revolucionária Paulista ${ }^{12}$ (que merda! porque esse P.S. ${ }^{13}$ não vai para a puta que o pariu?). ${ }^{14}$

\footnotetext{
${ }^{8}$ Entrevista reproduzida em O Estado de São Paulo, S5, 20/10/2012.

${ }^{9}$ Carta de MB a MA de 23/12/1931

${ }^{10}$ Partido Republicano Paulista.

11 Carta de MB a MA de 12/01/1044

${ }^{12}$ Manifesto "revolucionário" lançado, em 12 de novembro de 1930, por um aeroplano sobre a cidade de São Paulo e assinado pelos chefes revolucionários Miguel Costa, João Alberto e Mendonça Lima. O
} 
A necessidade de pagar pela própria edição e o agrupamento de escritores quer seja por afinidade literária, quer seja por amizade, favoreceram à formação de uma cooperativa em Minas Gerais, entretanto, de vida efêmera:

Liderada por Eduardo Frieiro entre 1931-1937, em Belo Horizonte. Literatos candidatos à publicação de livros como Carlos Drummond de Andrade, Ciro dos Anjos, Milton Campos, Aníbal Machado, dentre outros, formaram uma sociedade co-editora. Cedo os candidatos a escritores se desentenderam e apenas cinco livros foram feitos sob os cuidados da sociedade editora com a marca "Amigos do Livro" (1982, p. 151).

Se uns eram hostilizados, outros eram motivo de afeto e consideração. Era prática comum um escritor, ou poeta, enviar sua obra para seus pares, cuja opinião, mesmo se fruto de afeição pessoal, era aceita inconteste, conforme ilustra este trecho de outra carta de Bandeira a Mário:

Só quem sabia do meu segredo era Prudentinho ${ }^{15}$, a cujo juízo submeti todo o livro. Mas o nosso adorável amigo em vez de fazer uma leitura crítica, pega e me escreve uma declaração de amor, de um respeito, de uma ternura que me botou no sétimo céu da mais pura amizade. Por isso vou avisando que se houver alguma besteira grossa no livro, a culpa é do Prudentinho ${ }^{16}$.

Além disso, contendas comerciais vêm à tona. Monteiro Lobato declarava que acolhia os escritores contemporâneos, mas não teve boas relações com muitos. Lobato não gozava da simpatia de Manuel Bandeira. "Estive aqui com Monteiro Lobato que me prometeu muito meter agora a prelo o meu livro. Estou à espera", escreve Bandeira a Mário ${ }^{17}$, para depois de uns meses reclamar:

O Lobato acaba de roer a corda, comunicando-me que não editará mais os meus versos, para a publicação dos quais ele se comprometera formalmente há mais de um ano, compromisso esse várias vezes renovado, sendo que o último não data ainda de um mês. É um canalha, cuja palavra não merece fé. ${ }^{18}$

Mário de Andrade não era dado à bajulação e por não ser amigo de Lobato não conseguiu que este lhe publicasse os livros e teve de editar, à sua custa, a maioria dos livros que publicou antes de sua morte. A opinião que Mário tem de Lobato vai ao encontro daquela do amigo poeta: "Quanto ao Monteiro Lobato, quase já tirei a limpo

manifesto conclama o povo paulista a participar da "regeneração nacional" como estratégia continuada da ação revolucionária.

${ }_{13}^{13}$ Nota do editor: Plínio Salgado.

${ }^{14}$ Carta de MB a MA de 06/03/1931

${ }^{15}$ Prudente de Morais Neto.

${ }^{16}$ Carta de MB a MA de 23/05/1930.

17 Carta de MB a MA de 27/6/1923

${ }^{18}$ Carta de MB a MA de 24/09/1923 
que o caso dele foi só me prender e mais uma vez provar que é um f.-d.-p. muito grande". ${ }^{19}$ A antipatia por Lobato entre os modernistas não é nova e já tinha se manifestado na década de 20 por ocasião das críticas por ele feitas a Anita Malfatti, no artigo "Paranóia ou mistificação", injustamente na opinião de Edgard Cavalheiro:

Mesmo espíritos superiores, como Mário de Andrade e Manuel Bandeira, jamais perdoaram a Monteiro Lobato o artigo sôbre Anita Malfatti. E cometeram contra o escritor clamorosas injustiças. Bandeira, por exemplo, em "Noções de História das Literaturas" (Cia. Editôra Nacional, São Paulo, 1942) nem sequer o menciona [...]. (CAVALHEIRO, 1955, p. 711).

Edgar Cavalheiro (idem) ainda relata que Mário de Andrade, na conferência "O Movimento Modernista" menciona o autor de "Urupês" como sendo "pintor" e com e classifica o artigo sôbre a pintora de "um chorrilho de tolices que sacudiu uma população e modificou uma vida". O sarcasmo de Mário de Andrade ao referir-se a Lobato como "pintor" pode ser entendido assim: enquanto pintor Lobato escrevia bem. Ou seja, não tinha competência artística para julgar a pintura de Anita Malfatti, mas sobrava habilidade com a pena para criticá-la ferinamente. Mas, a manifesta implicância com Lobato por parte de muitos de seus contemporâneos pode ir além do episódio com Malfatti. Monteiro Lobato considera escrever um ofício e o livro uma mercadoria; sempre pensando no leitor, quebra o paradigma do escritor elitista que escreve para seus pares. Para Marisa Lajolo (2014, p. 18), Lobato "percebeu mais cedo do que muitos de seus contemporâneos (e até mesmo que alguns contemporâneos nossos) a completa pluralidade de papéis que espreitava a figura que já havia sido chamada de homem de letras na transição para a modernidade".

Ainda para Lajolo (idem), o polêmico Lobato sempre externou suas opiniões, frequentemente destemidas e "até hoje, ele e sua obra pagam o preço alto de um discurso móvel, dinâmico, muitas vezes incômodo". Não obstante essas desavenças entre os autores e o editor com relação à publicação de suas obras, é inegável o fato de Lobato ter impulsionado a indústria livreira e de ter sido um dos poucos autores a ter uma venda significativa de sua obra para adultos, Urupês, e para crianças com as histórias de Narizinho:

Monteiro Lobato foi o maior best-seller de 1937, com 1,2 milhões de exemplares de livros e traduções sob sua responsabilidade, ou seja, mais da metade dos 2,3 milhões de exemplares impressos pela Companhia Editora Nacional e sua

${ }^{19}$ Carta de MA a MB de 12/12/1930 
sucursal, a Editora Civilização Brasileira. Tal cifra corresponde a praticamente um terço da produção total brasileira nesse ano (MICELI, 2001, p. 146).

Apesar do desenvolvimento da atividade gráfica e editorial iniciada por Lobato, grande parte da elite literária dos anos 1930, assim como na década de 20, não só não conseguia se sustentar à custa da venda dos livros, como muitas vezes pagava do próprio bolso a edição de suas obras, conforme relatou Manuel Bandeira (1966, p. 87): "Em 1930, publiquei a minha quarta coleção de poemas: Libertinagem. Edição de 500 exemplares, impressa em Paulo, Pongetti \& Cia., mas custeada por mim". A articulação entre o sistema de produção, a circulação e a difusão, parece ainda não estar definida nem consolidada nesse período. Autores lançavam mão de uma teia de relações pessoais e políticas para conseguir editar suas obras e muitas vezes, os escritores buscavam entre seus pares, algum mecenas que se dispusesse a ajudá-los. O desabafo de Bandeira ilustra a situação dos muitos favores pedidos:

Em 1936, aos cinquent'anos de idade, pois, não tinha eu ainda público que me proporcionasse editor para os meus versos. A Estrela da Manhã saiu a lume em papel doado por meu amigo Luís Camillo de Oliveira Neto, e a sua impressão foi custeada por subscritores. Declarou-se uma tiragem de 57 exemplares, mas a verdade é que o papel só deu para 50 (BANDEIRA, 1966, p. 105).

A desorganização da atividade livreira nesse período, que prejudicava tanto editores quanto escritores, é ressaltada em estudo de Lajolo e Zilberman: "Em muitos escritores fica difícil separar o papel de vítimas das regras do sistema vigente do papel de coniventes com ela [falta de regras], ao editarem e venderem livros por conta própria, renunciarem aos direitos autorais, aceitarem pagamento simbólicos por sua produção" (LAJOLO; ZILBERMAN, 1996, p. 69). Essa situação pode ser mapeada em vários momentos na correspondência entre Bandeira e Mário. Frequentemente, o próprio autor se encarregava de distribuir suas obras às livrarias, ou pedia isso a amigos quando se tratava de outra cidade. Escreveu Bandeira a Mário: "Em julho mandar-lhe-ei algumas dezenas de exemplares para você me fazer o favor de colocar nas livrarias" e ainda: "Recebi [...] o exemplar de Macunaíma do Dante que deixei na Livraria Católica" ${ }^{20}$. Acrescente-se a esse cenário de precária remuneração do escritor, o fato de que eram frequentes as reedições clandestinas para burlar a lei dos direitos autorais. (EL FAR, 2004, p. 95).

\footnotetext{
${ }^{20}$ Carta de MB a MA de 26/07/1930.
} 
Para superar o problema, os escritores se promovem mutuamente, frequentemente através dos jornais, veículo de maior penetração naquele momento. A propósito de Libertinagem, comentou Bandeira: "Meu livrinho por aqui vai tendo pouca saída. Noticiário bem fraquinho. Agradeço-lhe o artigo do Diário". ${ }^{21}$ Nessa crônica, Puro e sem Mistura, Mário promoveu o novo livro de Bandeira qualificando-o, assim como a Drummond, de poetas individualistas, cujos poemas Mário considera "puros e sem mistura". 22

A incompatibilidade entre o caráter econômico/financeiro e o artístico nas produções culturais, "acompanha a concepção da irrelevância da materialidade econômica nos estudos da literatura, a imagem de despreparo do escritor para com os aspectos práticos da vida" (LAJOLO; ZILBERMAN, 2001, p. 71) e é consenso, mesmo entre os intelectuais. As cartas de Bandeira, no entanto, mostram o poeta atento aos assuntos financeiros e controlador minucioso de seus proventos da escrita. Em diversas ocasiões, Bandeira pediu a intermediação de Mário de Andrade, em São Paulo, para a cobrança de artigos vendidos aos Diários:

Agora um favorzinho que lhe peço. O Diário Nacional quando me fez o primeiro pagamento mandou-me essa nota da gerência onde não está inscrita a minha primeira colaboração [...]. Reclamei em carta ao Paulito que até hoje não me respondeu. [...] O cobre de julho ainda não veio. Você pode me ver isso na gerência? Desculpe apelar para você, não há outro jeito. Desde já obrigado. ${ }^{23}$

A ajuda mútua entre os escritores refletia a desorganização no mercado literário, com relação à edição e também à distribuição, divulgação e pagamentos. No que concerne aos últimos, mais uma vez, Bandeira recorria a Mário:

Tenho de recorrer a você, seu Mário: agüente a caceteação por amor do irmãozinho. Não posso deixar de recorrer a você porque da outra vez escrevi diretamente à redação e nem me responderam, e ainda com a sua intervenção não cumpriram o prometido, pois ainda nesta última remessa não me mandaram o dinheiro daquela famigerada crônica sobre o Graça! ${ }^{24}$

Dentre as mudanças que iriam afetar a definição social do trabalho intelectual na conjuntura das décadas de 1930 e 1940, a mais importante delas se refere à possibilidade que encontraram alguns escritores de se poder se dedicar à produção literária como sua principal atividade profissional. Dentre os poucos escritores que

\footnotetext{
${ }^{21}$ Carta de MB a MA de 26/07/1930.

${ }^{22}$ Cf. Marcos Antonio de MORAIS, 2000, p. 455, notas.

${ }^{23}$ Carta de MB a MA de 28/08/1930

${ }^{24}$ Carta de MB a MA de 24/11/1930
} 
puderam se dar ao luxo de em tempo integral viver de literatura estão Jorge Amado e José Lins do Rego (MICELI, 2001, p.187). Todavia, se levarmos em conta os problemas que Bandeira enfrentou com relação às publicações e aos pagamentos, conclui-se que a conduta dos editores na década de 30 não favorecia a maioria deles.

A falta de profissionalização e da infraestrutura necessária para a produção literária rentável levava muitos escritores ao jornal como solução para o problema financeiro, o que muitas vezes podia representar o primeiro passo para divulgação e venda das suas obras. Os escritores também buscavam no funcionalismo público a segurança financeira, paradoxalmente assumindo posições dentro de um governo que condenavam. Esta declaração de Carlos Drummond de Andrade, simpatizante da ideologia comunista, mas que viria a ser assessor do Ministro Gustavo Capanema confirma o fato:

O emprego do Estado concede com que viver, de ordinário sem folga, e essa é condição ideal para bom número de espíritos: certa mediania que elimina os cuidados imediatos, porém não abre perspectivas de ócio absoluto. [...] Observe-se que quase toda a literatura brasileira, no passado como no presente, é uma literatura de funcionários públicos. (Apud MICELI, 2001, p. 196).

A partir de uma visão simplista do momento histórico, John Milton aponta a ideologia do estado como o motivo que levou os intelectuais ao funcionalismo público: "Seja como for, o nacionalismo de Vargas atraiu um grande número de intelectuais brasileiros" (MILTON, 2002, p.26) e cita o cargo que Carlos Drummond de Andrade exercia como assessor do Ministro Capanema. Todavia, Antonio Candido, no prefácio de Intelectuais à brasileira, de Sérgio Miceli, ressalta que apesar de Carlos Drummond de Andrade "servir" o Estado Novo como funcionário público, "não alienou por isso a menor parcela de sua dignidade ou autonomia mental" (MICELI, 2001, p, 74). Drummond servia o Estado, mas não se engajou na sua ideologia e suas ideias contrárias ao regime eram conhecidas de todos. Ainda enquanto membro do gabinete do Ministro Capanema publicou os poemas políticos de Sentimento do Mundo e Rosa do Povo, que acrescentam o desencanto e o pessimismo ao tema social, como nos primeiros versos de A Flor e a Náusea:

Preso à minha classe e a algumas roupas, vou de branco pela rua cinzenta. Melancolias, mercadorias espreitam-me.

Devo seguir até o enjôo?

Posso, sem armas, revoltar-me? 
Observa-se que o cerceamento da liberdade intelectual e a sujeição à ideologia de estado não podem ser aplicados de maneira generalizada. De fato, parece que o governo "tolerava" divergências ideológicas desde que convenientes. A cooptação dos intelectuais para o serviço público seguia uma agenda política bastante pragmática, ao preencher cargos de confiança com nomes como Abgar Renault, Carlos Drummond e Augusto Meyer. A intenção era de limitar a autonomia das oligarquias políticas anteriores, conforme analisa Miceli (2001, p. 231). Dessa forma o governo ampliaria seu poder centralizador ao granjear a cultura em favor da política. Parece não interessar ao governo a qual corrente ideológica se filiava o intelectual, contanto que este fosse instrumento na construção de uma nova ordem político-social. Gustavo Capanema, o segundo Ministro da Educação e Saúde Pública, valendo-se da proposta modernista de busca de "brasilidade" e, ao mesmo tempo, da precária profissionalização da área, vai buscar dentre os escritores cooperação para seus projetos:

A gestão de Capanema erigiu uma espécie de território livre refratário às salvaguardas ideológicas do regime, operando como paradigma de um círculo de intelectuais subsidiados para produção de uma cultura oficial. À frente do Ministério da Educação e Saúde Pública desde 1934, convocou seus conterrâneos de geração que haviam participado do surto modernista em Minas Gerais, mobilizou figuras ilustres que haviam se destacado nos movimentos de renovação literária e artística da década de 1920, no Rio Grande do Sul, na Bahia, no Pará etc., acatando os representantes que a Igreja designava e cercando-se de um grupo de poetas, arquitetos, artistas plásticos, e de alguns médicos fascinados pela atividade literária (MICELI, 2001, p.218).

Um exemplo da atuação contraditória do regime com relação aos intelectuais é o caso de Graciliano Ramos, que exerce a diretoria da Instrução Pública de Alagoas, de 1933 a 1936. A seguir vem a prisão em 1936, sob a acusação de comunismo, sendo que somente em 1945 o escritor se filiaria ao PCB. A repressão, no entanto, não obstrui a publicação de Angústia, lançado durante o período de detenção. Nos anos 1940, Graciliano voltaria a trabalhar para o governo como revisor da revista Cultura Política, sob responsabilidade do Departamento de Imprensa e Propaganda (DIP).

Também Mário de Andrade e Manuel Bandeira tiraram grande parte do seu sustento de cargos públicos. O primeiro como diretor do conservatório artístico de São Paulo e o segundo como professor do Colégio Pedro II. Como tantos outros escritores do período, Bandeira engajou-se em projetos culturais do governo, principalmente os do então Ministro Capanema, como a elaboração de antologias poéticas para uso escolar. 
Em 1935, em documento assinado por Capanema e Getúlio Vargas, e lavrado em 14 de janeiro, Bandeira foi nomeado inspetor "interino e em comissão" de estabelecimentos de ensino secundário do Distrito Federal. O poeta apoiava a política cultural e educacional do governo e envolveu Mário em alguns dos projetos:

Confidencialmente: o Capanema tem idéias de mandar publicar pelo Ministério uma série de pequenos volumes sobre artes plásticas, música, etc. Biografias ilustradas e documentadas. Pediu-me que organizasse uma lista de nomes. Em matéria de música pensei logo em você [...]. Obra de valor instrutivo ${ }^{25}$.

Capanema também iria encomendar a Bandeira uma antologia dos parnasianos, dos simbolistas e pós-parnasianos, mas diante da incerteza política o poeta escreveu nessa mesma carta: "Acabei a minha antologia dos parnasianos. Se o Capa não ficar, terei perdido os meus três meses de trabalho". A política cultural da primeira década do governo Vargas foi assim de responsabilidade dos escritores, mas sempre ligados ao projeto do Estado. Dessa feita, "os intelectuais recrutados pelo regime Vargas assumiram as diversas tarefas políticas e ideológicas determinadas pela crescente intervenção do Estado nos mais diferentes domínios da atividade" (MICELI, 2001, p. 199). Entretanto, para Lajolo e Zilberman a interferência estatal revelou-se não só perniciosa aos intelectuais, mas também ao bom funcionamento da máquina governamental, uma vez que para alguns o cargo era mais um "cabide de emprego":

A nomeação de escritores para cargos públicos consistia, de um lado, na confissão de sua impotência institucional; de outro, na tentativa de remendar a impotência de forma canhestra, mutilando simultaneamente a instituição literária, por não reconhecê-la enquanto tal e o serviço público, no qual postulava a existência do ócio necessário à criação (LAJOLO, ZILBERMAN, 1996, p. 71).

Seja como for, o Estado foi o maior provedor de segurança material da qual os intelectuais necessitavam para poderem se dedicar à sua vocação primeira. De certa forma, o Estado assumiu o papel de mecenas ao incorporar os projetos dos intelectuais, que por um lado gozavam de um certo grau de autonomia adquirido no campo cultural fornecido e, por outro censurava sua produção.

\subsection{As letras e o poder}

\footnotetext{
${ }^{25}$ Carta de MB a MA de 19/03/1936
} 
Não se pode, todavia, generalizar a posição dos intelectuais com relação à ideologia do governo. É certo que muitos se engajaram na política, tanto com tendências de esquerda quanto de direita, conforme anota Pécaut (1998, p. 60): "Tornaram-se, mais do que nunca, politicamente engajados em sua maioria, mas segundo modalidades muito diversas e, às vezes, em campos opostos". Uma maioria tentava se manter independente, mas muitos atuavam como arautos da ideologia autoritária e colocavam o talento artístico a serviço da política oficial, como, por exemplo, o "Grupo Anta", liderado por Plínio Salgado, que se transforma na Associação Integralista Brasileira, de tendência fascista, com mais de um milhão de afiliados.

Esse grupo, porém, não conseguiu a aceitação pretendida no governo e tampouco a simpatia de alguns outros modernistas. Talvez porque "os verde-amarelistas entabularam um diálogo ambíguo com a tradição cultural", conforme analisa Elias Thomé Saliba, e enveredou por um "desdobramento do lado irracional do modernismo, aquele que eclipsou a razão, turvou as mentes e forjou mitos de mobilização política, conduzindo a desdobramentos políticos nefastos" (SALIBA, 2012, p. 281). A carta de Mário de Andrade ao amigo Bandeira é testemunho da rejeição: "Como vamos de regime novo? Aqui o pasmo é grande. Mas o nojo do integralismo era tão grande, que houve um verdadeiro desafogo de ver que eles não levam vantagem da situação". ${ }^{26}$ Pertencentes ao mesmo grupo literário inicial, o "Anta", Cassiano Ricardo e Menotti del Picchia fundam o grupo "Bandeira", que se alinhava mais à proposta getulista de "democracia social".

Com uma ideologia de direita, havia também membros da intelligentsia nacional que atuavam como defensores da moral cristã, ligados à Igreja, como Tristão de Athayde, nome literário de Alceu Amoroso Lima, que em 1932 fundou o Instituto Católico de Estudos Superiores. Dentre os escritores ligados à ideologia de esquerda achavam-se os regionalistas Jorge Amado, Graciliano Ramos e Rachel de Queiroz, esta responsável por apresentá-los ao PCB. Com a polarização ideológica, os escritores se colocavam politicamente, muitas vezes, por meio da literatura:

Num período de intensa concorrência ideológica e intelectual entre diversas organizações políticas (integralismo, Igreja, forças de esquerda), o romance converteu-se em móvel importante da luta em torno da imposição de uma interpretação do mundo social a um público emergente: os grupos de esquerda classificavam as obras dos romancistas identificados com a Igreja de romances "introspectivos" ou "psicológicos", os críticos de direita ou de tendências

${ }^{26}$ Idem 13/11/1937 
espiritualistas rotulavam as obras dos militantes de esquerda de romances políticos em sentido pejorativo, ou seja, como obras de propaganda e proselitismo (MICELI, 2001, p. 159).

Mas as tomadas de posição estavam sujeitas a mudanças. Mesmo aqueles que aprovaram o governo Vargas no início, mais tarde repudiariam o Estado Novo. Mário de Andrade, inicialmente, se demonstra entusiasmado com a revolução de 30 e declara no Diário Nacional (no artigo "Peneirando", em 2 de nov.): "O melhor é deixar que as paixões nos divulguem: viver. Viver apaixonadamente, participar, berrar, Getúlio! Getúlio! [...]". Mas, no ano seguinte, em carta de 27 de abril reclamou a Câmara Cascudo: "São Paulo está dominado agora por um pernambucano e um gringo ${ }^{27}$ [...] Onde vamos?", completando: "O separatismo grassa intenso". ${ }^{28}$ Mesmo assim, o desencanto com o governo varguista não impediu o escritor de assumir a diretoria do Departamento de Cultura de São Paulo, em 1934. O âmbito de aplicação do recémcriado Departamento de Cultura foi bastante amplo: da investigação cultural e demográfica à construção de parques e lugares para recreações, além de publicações culturais como aquelas encomendadas a Bandeira. Diferentemente de Mário de Andrade, Manuel Bandeira se mostrou, em vários momentos, mais moderado com relação ao engajamento em movimentos literários e políticos. Em primeiro lugar, não se considerava membro do movimento modernista. Em 1922, por ocasião da Semana de Arte Moderna, não quis ir a São Paulo participar, mas enviou à revista Klaxon (a primeira do movimento modernista), a pedido de Mário, o poema "Bonheur lyrique" e isso bastou para que fosse rotulado de modernista, conforme relatou: "Foi assim que me vi associado a uma geração que, em verdade, não era minha. [...]” (BANDEIRA, 1966, p. 70). Também, o poema "Os Sapos" lido na semana de 22, foi responsável pela inserção de Bandeira no modernismo. Contudo, como o próprio poeta afirma, a intenção foi mais uma crítica "contra certos ridículos do post-parnasianismo", parodiando Olavo Bilac em "Profissão de Fé". Mesmo não se considerando parte do movimento, foi por intermédio dele que o poeta conheceu a vanguarda brasileira.

Com relação à política, Bandeira iria compartilhar com Mário o júbilo primeiro por ocasião da revolução de 30: "Antes de mais nada, um abraço pela vitória da

\footnotetext{
${ }^{27}$ O então interventor de São Paulo João Alberto, o "tenente" do Nordeste, e Getúlio Vargas.

${ }^{28}$ Cf. Marco Antonio de MORAES. Correspondência: Mário de Andrade e Manuel Bandeira.2000, p.465 notas.
} 
revolução" ${ }^{29}$. Entretanto, na revolução de 32, iria reconhecer que o "sentimento era muito complicado e misturado" e que simpatizava com os paulistas "não-políticos", mas que não concordava com a revolução e "com a gente com que foi feita" ${ }^{30}$. Mas, Bandeira não tornou pública a sua opinião política nas crônicas que escrevia para os jornais como fez Mário de Andrade, atendo-se a pequenos comentários em âmbito privado. Apesar de diferentes visões de cunho estético e de caminhos ideológicos divergentes, é inegável a importância social alcançada pelos intelectuais e reconhecida por Bandeira em resposta a um questionamento de Mário de Andrade:

E a respeito das suas dúvidas e perplexidades: se a gente soubesse calcular sempre o alcance social do que faz, muito que bem e você teria em parte razão. Digo em parte porque o meu sentimento é que todo artista genuíno tem ação socializante mesmo quando pensa estar batendo a punhetinha mais pessoal na famosa Torre. Arte, como você disse na Escrava, é também comunicação e toda comunicação é socializante. ${ }^{31}$

Não obstante a situação ambivalente dos intelectuais que serviam o Estado, mas não compartilhavam com sua ideologia, estes se viam como responsáveis pela formação da cultura nacional. Nesse contexto, desenvolve-se uma inter-relação produtiva entre os projetos modernistas de cultura brasileira e a formação de nacionalismo de estado. Todavia, se por um lado o governo de Vargas representou avanço com relação a alguns projetos, por outro o modelo ditatorial foi um retrocesso.

\subsection{Identidade cultural e a formação da pátria}

Com a ascensão de Vargas ao governo, inicia-se a formação de um estado que é marcado pela transitoriedade e pela coexistência de formas novas e velhas. Não se pretende, neste estudo, uma na'lise profunda da história do período, pois como observa Edgar Carone (1978, p. 5) "neste momento de transição as questões são complexas e exigem análise acurada no geral e no particular". Assim sendo, vamos abordar apenas

\footnotetext{
${ }^{29}$ Carta de MB a MA de 29/10/1930.

${ }^{30}$ Idem 30/11/1932.

${ }^{31}$ Carta de MB a MA de 06/08/2012.
} 
algumas questões que possam estabelecer o contexto em que as traduções de Tarzan foram realizadas.

Mesmo com as ações governamentais de incentivo à industrialização, urbanização, consolidação, e profissionalização, do trabalho e expansão da rede de instituições culturais, a economia ainda é dominada pela agricultura, a ação do proletariado e da classe média continua limitada, muito em razão da atuação das classes tradicionais (apesar do o interregno do tenentismo) e a taxa de analfabetismo mantémse alta (CARONE, 1978, p. 5). De maneira geral, a mudança na conjuntura sóciopolítica influenciaria o povo, que, no entender de Vargas, carecia de valores pátrios e necessitava tutela. Portanto, o projeto do governo Vargas para a construção de uma identidade nacional tinha como método operacional a propaganda e a repressão, pois "o autoritarismo era uma resposta a uma demanda tácita do povo, desejoso de que lhe dessem uma imagem de sua unidade" (PÉCAUT, 1998, p. 56). Tal imagem foi promovida tanto pela ação do estado quanto pela dos intelectuais, coincidindo em alguns aspectos.

O Estado inicia em 1930 a marcar presença na vida cultural brasileira através de instituições como o Instituto Nacional do Cinema Educativo e o Serviço do Patrimônio Histórico e Artístico Nacional e de órgãos de propaganda com a criação do Departamento de Propaganda e Difusão Cultural, em 1934. A propaganda utilizava vários meios de veiculação, livro, cinema e rádio, sendo que a escola apresentava-se como o lugar ideal para a divulgação do que seriam os "valores pátrios". Uma página de um livro de história, publicado pela editora Noite, em 1943, ilustra bem a ideologia ufanista do estado. Com o título sugestivo de "Formação da Pátria", apresenta figuras representativas do progresso, da família e das forças armadas ao redor de um mapa do Brasil e encimadas pelo retrato de Getúlio Vargas. 


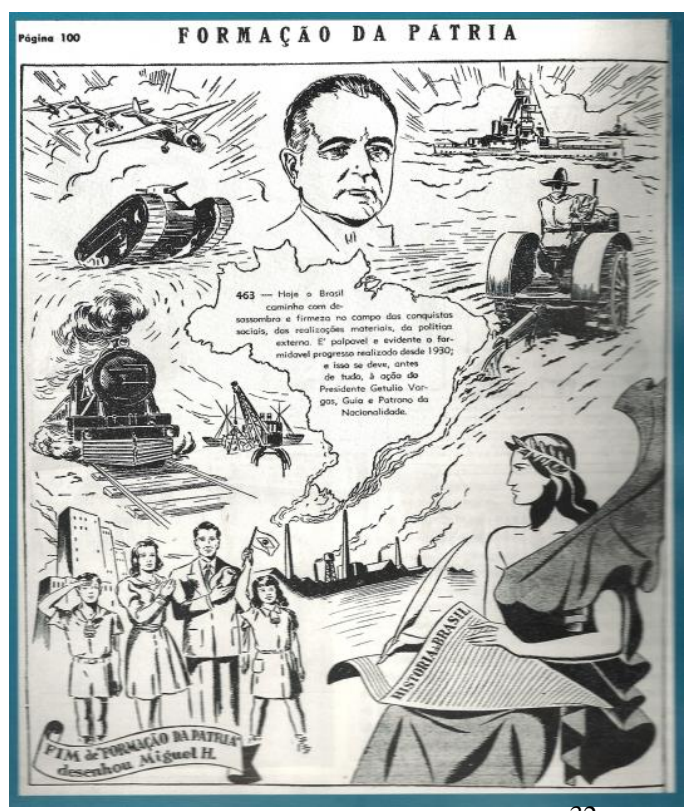

Figura 1: Formação da Pátria ${ }^{32}$

Nessa página temos a valorização quase hagiográfica da imagem de Vargas, uma das características de governos populistas, e a difusão da ideia de desenvolvimento e progresso, associando o líder a sua obra. A ideia de valorização da "brasilidade" fundese com o projeto político e passa a "evidenciar a paternal preocupação do dirigente com a cultura de seu país" (HALLEWELLL, 1985, p. 313).

Uma das providências para a o estabelecimento e manutenção desse status foi a criação do Departamento da Imprensa e Propaganda (DIP), em 1939, consolidando um processo que já se iniciara anos antes. Substituindo o antigo DEOPS (Departamento Estadual da Ordem Pública e Social), de 1927, o órgão tinha a dupla função de controlar qualquer produção cultural, funcionando por intermédio da censura como instrumento moralizador, e ainda de suscitar o patriotismo por meio de propaganda, em ambos os casos colaborando para a construção de uma imagem positiva do governo. A construção da identidade nacional vai passar por essas mediações, obliterando tudo que não se conforma aos "parâmetros simbólicos" - língua comum, heróis, folclore - eleitos pelo governo, "que funcionam como 'provas' da existência desse Estado, e que determinam sua originalidade" (FIGUEIREDO, 2005, p. 192). O nacionalismo programático do governo Vargas iria no correr da década resultar em radicalismo ideológico com consequente "caça às bruxas". Mesmo assim, os intelectuais perseguidos pelo governo

\footnotetext{
${ }^{32}$ Fonte: Momentos do livro no Brasil. São Paulo: Ática, 1997. Edição comemorativa. p. 100.
} 
contribuíram, ainda que não deliberadamente, com o projeto governista paraa cultura, como, por exemplo, o caso já citado de Graciliano Ramos. Isso porque, "O Estado, apresentando-se como responsável pela identidade cultural brasileira, desejava realizar a unidade orgânica da nação e recorria aos intelectuais para alcançá-la" (PÉCAUT, 1998, p. 59), mas não sem antes circunscrever a atividade ao âmbito "oficial" e intervir em todos os setores de produção e difusão da cultura.

A confluência da consciência criadora dos homens de letras com as ações de política cultural do estado resulta num período fecundo para a literatura brasileira que se estrutura a partir da nova realidade cultural, social e política. Para Wilson Martins, a ruptura mental que a revolução de 1930 representou para as gerações contemporâneas foi "tão completa com o passado que não seria extravagante vê-la como fenômeno histórico e social que assegurou a vitória do Modernismo". Ainda para esse autor, o Modernismo, a partir de 1930, "conclui a metamorfose para o moderno e assume as suas opções sociais em lugar da gratuidade estética de que até então tinha vivido" (MARTINS, 1978, p. 497).

Com frequência confunde-se a Semana de 22 com modernismo. A importância desse evento é inegável, mas o modernismo não se resume a ele. Segundo Bosi (1994, p. 303), "O que a crítica nacional chama de Modernismo está condicionado por um acontecimento, isto é, por algo datado, público e clamoroso, que se impôs à atenção da nossa inteligência como um divisor de águas". Mais do que um evento, o modernismo foi um movimento em direção à construção de uma identidade brasileira.

No Modernismo, o ponto de ancoragem de uma identidade achava-se na busca de raízes culturais e na discussão sobre a língua "brasileira", refletindo, como em nenhum outro período "os movimentos da alma nacional" (CANDIDO e CASTELLO, 2006, p. 11). "Todos buscavam uma síntese que incluísse, filtrasse e integrasse, como num caleidoscópio cubista, elementos históricos, populares, modernos e nacionais", ressalta Saliba (20012, p. 278). Contudo, muitas vezes em grupos e outras individualmente os "homens das letras" escolheram caminhos e formas diferentes nessa busca. Assim, muitas vezes sem perceber, os intelectuais acolheram projetos culturais oficiais de cunho nacionalista:

Dando sequência à postura inaugurada pelos modernistas, esses intelectuais cooptados se autodefinem como porta-vozes do conjunto da sociedade, passando a empregar como crivos de avaliação de suas obras os indicadores capazes de atestar 
a voltagem de seus laços com as primícias da nacionalidade (MICELI, 2001, p.216).

Por conseguinte, Vargas enquanto "guia e patrono da nacionalidade" buscava subsídios no projeto modernista para a construção da identidade nacional. $\mathrm{O}$ fato de que "o Modernismo revelou, no seu ritmo histórico, uma adesão profunda aos problemas da nossa terra e da nossa história contemporânea" (CANDIDO; CASTELLO, 2006, p. 11) demonstra que as propostas modernistas de renovação estética, e de rejeição de modelos importados e os projetos do governo Vargas imbricavam-se em alguns pontos. "É nesse contexto, sem dúvida, que tomou corpo a concepção de "cultura brasileira" sob cuja chancela, desde então, se constituiu uma rede de instâncias de produção, distribuição e consagração de bens simbólicos às custas das dotações oficiais" (MICELI, 2001, p. 216).

A busca dos modernistas por uma identidade cultural levou à pesquisa do folclore na "certeza de que as raízes brasileiras, em particular, indígenas e negras, solicitavam um tratamento estético, necessariamente primitivista" (BOSI, 1994, p. 341). Iniciada por Mário de Andrade, na década de 20, a pesquisa se tornou oficial em 1938, quando o Departamento de Cultura de São Paulo, chefiado pelo escritor, financia a Missão de Pesquisas Folclóricas. Outro exemplo, ainda na esteira da construção de uma identidade brasileira, foi o projeto de elaboração de uma Enciclopédia Brasileira, do Instituto Nacional do Livro, sob responsabilidade de Mário de Andrade, mas que não foi levado a termo, tendo sido cancelado logo no início.

A subversão dos modernistas aos padrões literários importados abrangeu não somente a busca de uma temática "brasileira", mas também à língua. "Do ponto de vista estilístico, pregavam a rejeição dos padrões portugueses, buscando uma expressão mais coloquial, próxima do falar brasileiro" (CANDIDO; CASTELLO, 2006, p.12), mais adequada para exprimir a vida diária, condizente com a civilização moderna, tão caros aos novos temas literários. Entretanto, nem mesmo entre os próprios escritores havia um consenso quanto ao grau de transgressão linguística que deveria ser adotado, como se pode notar em vários momentos na correspondência entre Mário de Andrade e Manuel Bandeira. Por exemplo, Bandeira condenaria Mário pelos "brasileirismos indiscretos, propositais, colocações de pronomes acintosas", ao que Mário o acusaria de "um 
enquizilamento constante reacionário" ${ }^{33}$. Bandeira assim explicou seu conservadorismo linguístico a Mário de Andrade:

Quando você escreve "sube" e "intaliano", ninguém sente o seu desejo de comunhão nem o seu sacrifício, mas a sua personalidade indiscreta e tirânica querendo impor na linguagem literária escrita formas da linguagem popular ou culta falada que agradam à sua sensibilidade de grande escritor ${ }^{34}$.

Passados os anos de radicalismo estético, Mário de Andrade confessaria ao amigo Bandeira: "É engraçado, mas eu trago, não propriamente da minha geração, mas pelo menos de duas que antecederam a minha, um desejinho secreto de falar bem o português e escrevê-lo sem erro" ${ }^{35}$.

A busca de uma língua brasileira lançada no modernismo se realiza, no nível governamental, em sucessivas mudanças ortográficas. A necessidade de se adequar o sistema ortográfico às peculiaridades da língua "brasileira" é debate constante. Apesar de ter sido objeto de discussão desde o século XVIII, a polêmica ganha força nos anos 1930 com a afirmação de um nacionalismo linguístico. Além do aspecto ideológico, o crescimento do mercado editorial fez com que a reforma se torne indispensável.

Em 1931, o Decreto 20.108, estabeleceu o primeiro acordo ortográfico entre Brasil e Portugal, proposto pela Academia Brasileira e a Portuguesa, e que visava suprimir as diferenças, unificar e simplificar a língua. Vargas, numa atitude de cunho nacionalista se colocou contra essa unificação, que considerava ser subserviente a Portugal. Com a promulgação da constituição Federal, em 1934, Vargas revogou esse acordo, voltando ao sistema ortográfico anterior. A intromissão do governo em questões que a sociedade considerava do âmbito acadêmico gerou protestos e debates. Mesmo assim, o governo não cessou de legislar sobre a língua e promulgou uma série de decretos sobre a questão ortográfica. Essa constante mudança com relação à ortografia somou-se aos tantos problemas já enfrentados pelas editoras, como a escassez de matéria prima e as reformas no ensino, que atingiriam a publicação dos livros didáticos.

Na prática as duas ortografias coexistiam. Apesar de a Constituição de 1934 ordenar a adoção da ortografia "antiga" nos livros didáticos, muitos estados optavam por uma ou por outra. Essa situação criou um grande problema para a indústria editorial, conforme relata Monteiro Lobato:

\footnotetext{
${ }^{33}$ Cartas de MB a MA de 17/06/1929 e 1/07/1929.

34 Idem 06/08/1931.

${ }^{35}$ Carta MB a MA de 2601/35.
} 
A Cia. Editora Nacional, por exemplo, que é onde dito meus livros, tem estoque de 800.000 coisas escolares, metade na nova, metade na velha... E se agora a nova ortografia é adotada nas escolas, essa benemérita empresa sofrerá grande perda, com inevitável encalhe dos 400 mil volumes que depois de 34 teve de editar na velha. Na mesma situação se acham as demais casas editoras que também exploram o livro didático (LOBATO, 1957e, p. 158).

Em 1936, o Departamento de Educação do Distrito Federal adotou a denominação língua brasileira nas publicações oficiais, assim justificada pelo ministro Francisco Campos, em citação de Wilson Martins (1996, p. 81): "E por que língua brasileira? - Língua brasileira porque povo brasileiro". O ministro advogava uma libertação dos padrões da língua culta portuguesa, valorizando aspectos que também se achavam na identidade brasileira que o estado pretendia construir: "língua fresca, viva e ágil; rebelde e amorosa; pitoresca e cheia de malícia".

O interesse pela questão da língua brasileira fomentou publicações como o Dicionário de verbos e regimes, de Francisco Fernandes e A ortografia simplificada ao alcance de todos, por Antenor Nascentes. O exagero nacionalista culminaria na obra bizarra do General Bertoldo Klinger, "que tendo malogrado, em 1932, na tarefa de reformar a vida política do país, desejava ao menos reformar-lhe o sistema de escrita, criando então a O.S.B. (Ortografia Simplificada Brazileira)" (MARTINS, 1996, p. 159). Em um compêndio de 64 páginas, lançado em 1940, Klinger apresentava suas propostas de grafia com aproximação fonética buscando uma uniformização, que segundo ele, facilitaria a alfabetização. Dentre as novas sugestões, citamos: exemplo - ezemplo; flexão - flecção; nasal - nazal. O militar ainda sugeriria a abolição do acento grave e do trema "por inúteis e desnecessários". Desse momento em diante, Klinger passaria a escrever tudo conforme a nova cartilha, assinando "Jeneral" Klinger.

Em 1942, o Ministro Capanema, em discurso na Academia Brasileira de Letras, apelaria para que os acadêmicos elaborassem um vocabulário ortográfico com modificações que respeitassem o falar brasileiro, revelando uma consonância entre o projeto de Vargas e o dos intelectuais:

O projeto do regime pretendia-se mais "cultural" do que mobilizador, e a definição do "cultural" confundia-se amplamente com a dos intelectuais. Trata-se de construir o "sentido da nacionalidade", de retornar às "raízes do Brasil" de forjar uma "unidade cultural" (PÉCAUT, 1995, p. 69).

Apesar de a temática e a linguagem do modernismo, geradas pela ânsia por uma "brasilidade", aproximarem-se do cotidiano brasileiro, a "cultura" pretendida pelos 
intelectuais não era, todavia, uma cultura para o uso do povo e sim continuava sendo uma cultura elitista mais afeita às renovações estéticas. Bandeira escreve a Mário:

A sua nobre tentativa de linguagem brasileira, feita no pensamento de nos unir mais os brasileiros, idéia portanto altamente socializante, se tem afirmado dessocializante: a maioria das pessoas simples que lêem você sentem dificuldade de compreendê-lo ${ }^{36}$.

$\mathrm{Na}$ "comunidade imaginada" de um novo Brasil persistia, apesar de todos os projetos oficiais, a dicotomia cultural, de um lado a elite e de outro a massa, que preferia ainda o folhetim e o rádio. Adriana Florent conclui: "De fato, apesar de uma tentativa de democratização cultural, a separação entre cultura popular e cultura erudita permanece ainda bem nítida, mesmo entre aqueles que mais contribuíram para combatêla, os escritores regionalistas" (FLORENT, 2011, p. 39). Assim, voltamos a uma questão já mencionada: o público leitor dos escritores era formado por seus pares e a população, que carecia de educação, voltava-se ao entretenimento de massa. Nesse quadro já bastante complexo ainda há a atuação da censura, que por um lado cerceando e amordaçando a cultura e as ações do governo estimulando projetos de construção identitária.

\footnotetext{
${ }^{36}$ Carta de MB a MA de 06/08/1931.
} 


\section{A PRODUÇÃO LITERÁRIA NA ERA VARGAS}

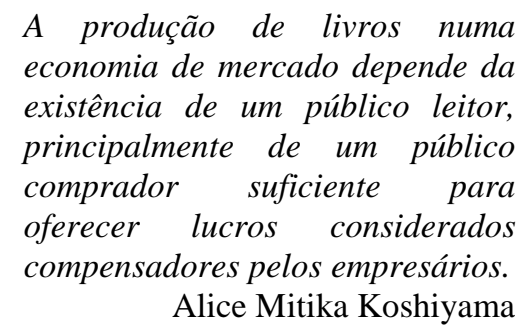

\subsection{Censura e a indústria livreira}

Desde os primórdios de nossa história a censura, exercida tanto pela Coroa quanto pela Igreja, controlava o que se podia falar, ler e escrever, visando calar as vozes dissonantes para garantir a manutenção de um status quo. A associação entre esses dois poderes se reflete na nomeação dos quatro primeiros censores no Brasil, em 1808, dos quais dois eram religiosos: frei Antonio da Arrábia e padre João Manzoni. Com a Proclamação da Independência a censura foi oficialmente abolida, mas oficiosamente continuava a existir com relação aos jornais que abraçavam os ideais da Revolução Francesa e, também, com relação à leitura para os jovens e mulheres.

Entretanto, a censura é uma prática que não se conforma com análises generalizadas, pois ocorre em diversos níveis e sob pretextos diversos, sendo dependente dos interesses da autoridade vigente. A julgar por casos documentados, a censura durante o período varguista parece ter sido marcada pela falta de lógica e pela improvisação. Sumárias rotulações começaram a ocorrer no início da década com a polarização entre direita e esquerda. Duas obras - $O$ esperado, de Plínio Salgado, e $O$ país do carnaval, de Jorge Amado - publicadas no mesmo ano de 1931, foram rotuladas pela censura: a primeira considerada anticomunista e a segunda comunista. Esse julgamento sumário, apontado por Wilson Martins, "desmente mais uma vez a lógica prévia das simplificações" (MARTINS, 1978, p. 513). Adversário político e ideológico 
de Plínio Salgado, a obra de Jorge Amado teve reconhecimento por parte do público e da academia. Tido como de esquerda, tomaria, em 1961, assento na Academia Brasileira de Letras, templo do conservadorismo, ao passo que Salgado seria preterido, não obstante ser escritor de "superiores recursos" (MARTINS, 1978, p. 513).

A atuação arbitrária da repressão do governo varguista desenvolveu-se em um crescendo. Com a ascensão de Getúlio Vargas ao governo, logo após a Revolução de Outubro, diante da perspectiva de grandes mudanças, acreditava-se na extinção da censura. Segundo Hallewell:

Acabar com a censura foi uma das metas declaradas da revolução de 1930, mas nunca efetivada, exceto durante a breve passagem de Maurício de Cardoso pelo Ministério da Justiça (de dezembro de 1931 a fevereiro de 1932); mas ele renunciou, envergonhado com sua incapacidade de controlar a ação dos interventores em cada um dos estados (HALLEWELL, 1985, p. 368).

Ocorreu exatamente o inverso: a censura não foi extinta, mas recrudesceu. Em 1934, com a promulgação da constituição e com a eclosão da "Intentona Comunista", foi decretado o estado de sítio: "Sob o pretexto de subjugar o 'polvo vermelho', o governo suprimiu todos os direitos que garantiam a liberdade dos cidadãos previstos pela lei" (FLORENT, 2011, p. 180).

A liberdade de expressão ficou restringida, as diversões públicas eram controladas e não se permitiam críticas ao governo e aos que dele faziam parte. A partir desse momento, deu-se a reestruturação dos órgãos censórios buscando maior eficácia. No dia 10 de novembro de 1937, Vargas anunciaria o Estado Novo, iniciando um período de ditadura no Brasil. Em 1939, é criado o DIP (Departamento de Imprensa e Propaganda), cujas atribuições eram centralizar e coordenar a propaganda nacional, promovendo ou patrocinando manifestações cívicas e de divulgação das atividades do governo, além de censurar todas as manifestações culturais e recreativas, teatro, cinema, literatura, eventos esportivos. Maria Lucia Tucci Carneiro expõe as razões que levaram a tal cerceamento:

O governo estadonovista buscava, como a maioria dos regimes autoritários, o singular, ou seja, a homogeneidade em todos os níveis, de forma a facilitar a dominação, o controle. E, nesta direção, múltiplos discursos foram articulados, oferecendo interpretações do mundo e da realidade brasileira, criando novos significados. A fim de superar a crise de legitimidade e interferir no imaginário político, o Estado procurou gerenciar o universo simbólico dos grupos subalternos mantendo-os, sempre que possível, alienados e conformados (CARNEIRO, 2002, p.31). 
Como frequentemente ocorre em regimes ditatoriais, a censura funcionava como instrumento que se pretendia "moralizador" e que contribuía na construção de uma imagem positiva do estado. Ao manipular a opinião pública através da propaganda, a repressão ganhava apoio da população, principalmente a partir de 1935. "Getúlio Vargas faz com que o medo da eventualidade de um 'terror vermelho' imposto pelos comunistas se espalhe em todo o país" (FLORENT, 2011, p. 279). Para esse governo, cuja tarefa era de "civilizar" e "enquadrar", sob o pretexto de defender a moral, os bons costumes, a justiça, a ordem e a segurança nacional, o medo era arma poderosa para ganhar apoio da sociedade e "o 'credo vermelho' transformou-se na nova heresia do século 20" (CARNEIRO, 2002, p. 109). Para essa "cruzada moralizadora" o governo contou ainda com o apoio das organizações religiosas.

O estado reconhecendo o poder da palavra promoveu buscas e queimas de livros considerados "nocivos à sociedade" e perseguiu os homens de letras - editores, escritores, intelectuais -, os suspeitos de sempre:

Vargas, consciente do papel representado pelos livros, sustentava como princípio o fato de que todo intelectual e seus escritos eram perigosos. [...]. Mas também, os professores, os médicos, os acadêmicos de direito, os judeus, especialmente aqueles de nacionalidade russa ou lituana, os operários, em grande parte imigrantes e alfabetizados, eram atentamente vigiados (CARNEIRO 2002, p. 155).

Todos os veículos de comunicação sofriam com a ação censória. Érico Veríssimo assim relata em suas memórias por que decidiu encerrar seu programa infantil na Rádio Farroupilha:

Quando em 1937 Getúlio Vargas instituiu o Estado Novo e o famigerado DIP começou a exercer rigorosa censura sobre a imprensa e as estações de rádio, fui notificado de que dali por diante o Amigo Velho teria de submeter previamente suas estórias ao Departamento de Censura, antes de contá-las aos seus pequenos ouvintes. (Como as ditaduras temem as palavras!) (VERÍSSIMO, 1973, p. 262).

O pretexto para a proibição ia desde aspectos morais, como atentado ao pudor e anti-clericalismo, a aspectos políticos, como retórica comunista, oposição ao governo, e, às vezes, ela era motivada por agenda pessoal do censor, "mas nem sempre o confisco se fazia com base em justificativas objetivas. As ordens de confisco chegavam a ser endossadas e cumpridas por todos os departamentos que, sequer, se interessavam em avaliar o conteúdo da referida obra" (CARNEIRO, 2002, p. 65). Vários fatores, aparentemente inócuos, concorreram para a proibição das obras, pois o censor seguia seus códigos particulares de julgamento. 
Da lista de livros "nocivos à sociedade", dentre os quais os de Jorge Amado, de José Lins do Rego, de Rachel de Queiroz, de Graciliano Ramos, de Gilberto Freyre, constavam também obras de literatura infantil:

As obras de Monteiro Lobato foram arbitrariamente queimadas e Aventuras de Tom Sawyer foi julgado tão perigosamente subversivo que, não satisfeito em confiscar a edição, o governo prendeu Cecília Meireles por tê-lo traduzido (HALLEWELL, 1985, p. 370).

A perseguição a Monteiro Lobato foi a que mais exemplifica a paranoia da censura. Peter Pan, A História do Menino que não Queria Crescer, Contada por Dona Benta sofreu ataques do Dr. Clóvis Kruel de Morais, conforme relata Carneiro:

Kruel via um confronto premeditado na parte que se referia às diferenças de vida entre crianças da Inglaterra e as do Brasil. Considerava o texto perigoso, pois este incutia às crianças brasileiras 'a nossa inferioridade, desde o ambiente em que são colocadas até os mimos que se lhe dão. Pront. $n^{\circ}$ 6575, José Bento Monteiro Lobato DEOPS/SP. AESP (CARNEIRO, 2002, p. 151).

Somada a essa crítica estava a do procurador Tupy Caldas, que no "prontuário $\mathrm{n}^{\circ}$ 6575, José Bento Monteiro Lobato DEOPS/SP. AESP" classificou as obras de Lobato em grupos distintos:

- História do mundo para crianças: onde domina o espírito materialista;

- Memórias da Emília: onde domina um espírito de troça das coisas sérias, além do mesmo sentimento materialista que traz à tona "as convicções íntimas do autor", concluindo que tais obras expõem as crianças "a doutrinas perigosas e a práticas deformadoras de caráter" (Apud CARNEIRO, 2002, p. 155).

Talvez a censura a Lobato se deva mais às suas opiniões provocativas que propriamente à sua produção literária. Mesmo assim, já neste século 21, Lobato foi alvo de "guardiões" do politicamente correto que queriam mutilar sua obra infantil extirpando os elementos considerados racista (o tratamento dado à tia Anastácia) e antiecológico (as caçadas de Pedrinho). Os tempos mudam, mas a estreiteza do pensamento censor não.

Assim como no caso da adaptação de Peter Pan, não somente os autores brasileiros eram censurados, mas também as traduções. A tradução de Point counterpoint, de Aldous Huxley, por Érico Veríssimo (1987, p. 256) “contou desde logo com a má vontade do clero católico, e [o livro] foi tão violentamente denunciado por certos críticos do centro e da direita" o que levou o tradutor a ser fichado como comunista, mesmo tendo sido condenado também pela esquerda. 
O caso mais bizarro foi o do livro de aventuras Tarzan, o Invencível. Quando Tarzan foi lançado no Brasil, a afinidade do governo Vargas com os regimes nacionalista e fascista revelava-se no antissemitismo, na eugenia e na repressão ao comunismo. A instauração do Estado Novo tem sua ideologia repercutida favoravelmente na Alemanha e na Itália, tanto assim que o presidente do senado italiano considera o golpe de Vargas uma herança da cultura italiana (Dulles, 1967, p.185). A exemplo desses países, o estado brasileiro concentra em um só "selvagem" todas as ideologias contrárias ao estado, elegendo-o como o inimigo que desejava combater:

As autoridades oficiais, influenciadas pela literatura antissemita nacional e internacional expressiva dos anos 1930 e de 1940 estigmatizavam aqueles que além de judeus eram também comunistas [...] Além de serem considerados elementos indesejáveis à composição da raça brasileira (idealizada como branca e católica), os judeus acumulavam outros estereótipos que os associavam à prostituição, ao tráfico de mulheres brancas, ao jogo e à trapaça (TUCCI, 2002, p. 267).

A paranoia anticomunista levou à apreensão de um dos livros do herói anglosaxão, tão aceito pelo público e aparentemente inócuo, pela polícia no Rio de Janeiro, um mês após o "auto de fé" baiano de 19 de novembro de 1937. Em Tarzan, o invencível, com tradução de Paulo de Freitas, os bandidos, por serem soviéticos, empregavam a expressão "camarada" considerada como representativa de uma retórica comunista. Paradoxalmente, nesse caso, os censores, não levaram em consideração a lição de moral com a consequente punição por parte de Tarzan dos malfeitores comunistas, segundo o maniqueísmo do gênero. Cada personagem tem papel bem definido no desenvolvimento da história.

As obras censuradas alegadamente iriam de encontro ao projeto do estado de formar uma juventude patriótica, saudável e cristã, nos moldes da juventude nacional socialista: "As iniciativas do Tribunal de Segurança Nacional apresentavam-se como parte do projeto político do Estado Novo voltado para a formação de uma juventude patriótica, continuadora da tradição cristã, unificadora da Pátria" (CARNEIRO, 2002, p. $155)$.

Apesar de a censura não ter sido uma ação homogênea e generalizada, ela exercia uma incômoda influência na vida das editoras. Segundo Érico Veríssimo (2005, p. 77), a Editora Globo foi acusada de ser "vermelha", pois entre seus tradutores havia comunistas confessos e suas publicações revelavam "nítidas tendências bolchevistas". Por outro lado, a mesma editora também era acusada pela esquerda de estar "a serviço 
de Wall Street". Apesar disso, o resultado foi que nenhuma sanção foi imposta à editora. José Olympio, cuja editora era famosa por promover escritores brasileiros, reconheceu naqueles tempos que: "O que tem causado um enfraquecimento do mercado é a apreensão de livros em todo o território nacional, sem que na maioria das vezes obedeça a um critério justificável" (OLYMPIO, 1939, p. 401). Para Carneiro, as consequências foram desastrosas:

O Estado, censor por excelência, foi responsável pela mutilação da cultura nacional, interferindo, negativamente, na construção do conceito de cidadania. O aparato policial, organizado durante décadas e que perseguiu os "homens de ideias", deve ser considerado como um dos promotores da barbárie, da violência, da segregação e da intolerância, marcas registradas do século 20 (CARNEIRO, 2002, p. 22).

Contudo, esse período tão conturbado rendeu alguns bons frutos. Se, por um lado, a busca de uma unidade ideológica por meio da repressão de vozes dissonantes no meio literário amordaçou a cultura, por outro fomentou o desenvolvimento da indústria livreira. A censura estadonovista que levaria escritores brasileiros à prisão, com a apreensão e destruição de obras, parece ter sido um dos fatores que contribuíram para o aumento de tradução de ficção estrangeira. A publicação de obras traduzidas, livros didáticos e de literatura infantil foi uma maneira encontrada pelas editoras e escritores não só para resolver a questão financeira, mas também para manter um vínculo com o incipiente público leitor, sem com isso se indispor com o estado censor.

\subsection{Não há literatura sem leitor}

Seria uma visão simplista, contudo, considerar a censura do Estado Novo como único responsável pelos novos rumos do mercado editorial. A necessidade de mudança já havia sido observada por Lobato em 1923, atestando que um fator mais determinante que a censura é a falta de público leitor. A necessidade de formação desse público é premente para uma atividade que envolve muitos setores:

Numa economia de mercado a produção de livros está vinculada à atividade dos seguintes elementos: empresários (editor, gráfico, livreiro); trabalhadores vinculados à empresa editora, gráfica e livreira; os trabalhadores intelectuais (escritores e tradutores de textos) os consumidores do produto livros (compradores e/ou leitores) (KOSHIYAMA, 1982, p. 8). 
Preocupado com o futuro da editora, o escritor taubateano escreve a seu amigo Rangel: "Estamos refreando as edições literárias para intensificação das escolares. O bom negócio é o didático" (LOBATO, 1957a, p. 260). Pelo que Márcia Cabral da Silva observa, o livro didático já era no final do século 19 "um tipo de impresso numeroso, o que apontava para fonte de lucros e vantagens", mesmo com o déficit de escolas em relação à demanda, e completa:

Foi assim com sucessivos livros de leitura idealizados por Abílio César Borges, o Barão de Macaúbas, ${ }^{37}$ e também com as primeiras cartilhas produzidas para o leitor brasileiro, voltadas para o ensino estrito da leitura e da escrita, que conheceram várias reedições (SILVA, 2009, p. 120).

Lajolo (2009, p. 96), compara os rendimentos de Machado de Assis com os de Fernando Pinheiro, "prolífico autor de obras escolares" do século 19, demonstrando que à época os didáticos eram mais rentáveis que literatura, num momento em que o Brasil estava então engatinhando rumo a um maior acesso à educação. No século seguinte, o romance-folhetim, publicado nos rodapés dos jornais, começou a ceder lugar aos romances em livro, "obras escritas ao sabor do grande público" no dizer de Alessandra El Far (2004, p. 24), que também era leitor do jornal impresso e dos almanaques. O processo de popularização da leitura iria ganhar fôlego com a mudança política nos anos 30, com a criação de um órgão específico para tratar da instrução e da cultura, o Ministério da Educação e Saúde. "De lá vieram novas medidas, a vida escolar se organizou, o livro didático, precisando responder às novas questões, deu outra forma ao ensino, sobretudo ao da leitura e literatura" (LAJOLO; ZILBERMAN, 1996, p. 156).

$\mathrm{Na}$ institucionalização de uma política de cultura, o livro seria um instrumento para "afirmar a civilização e a cultura nacionais" (DUTRA, 2013, p. 229). A reforma educacional empreendida pelo ministro Capanema, contudo, com um projeto sistematizado de ensino que visava à alfabetização, foi insuficiente na formação do público leitor. Com relação à geração adulta na época, esta era fruto do ensino precário do século anterior e de um mercado editorial pouco organizado e ineficiente, fatores que não favoreciam um ambiente de estímulo à leitura.

\footnotetext{
${ }^{37}$ Livros escolares de Abílio César Broges: Livro de leitura, ${ }^{\circ}$ 1, 2, 3, 4, 5; Livro do povo ou Syllabario brazileiro; Resumo da grammatica portuguesa; Epítome da grammatica franceza; Desenho linear ou Geometria prática popular; Luziadas de Camões (Edição escolar); Cantos escolares: compêndio de musica; Pequeno tratado de leitura em voz alta; Methodo para o ensino pratico da língua franceza. Fonte: SILVA p. 69.
} 
A questão da promoção da leitura não se resumia ao analfabetismo. Conforme concluem estudos contemporâneos, há uma diferença entre alfabetização e letramento: o primeiro se restringe à técnica do ler e escrever, enquanto o segundo é mais amplo, indo da decodificação de letras e fonemas à capacidade de "responder às demandas sociais, decorrentes das relações entre os indivíduos, em uma sociedade grafocêntrica" (SILVA, 2009, p. 105). O letramento tem papel fundamental para a formação do público leitor e para isso concorrem, além da alfabetização, aspectos ambientais e materiais relacionados à leitura. No âmbito privado, estudiosos apontam a relevância de um ambiente familiar letrado, "que propicie acesso a materiais de leitura diversificados, situações sociais de utilização da escrita e da leitura e mesmo a audição de histórias [...]" (Idem, p. 117). Na esfera pública, não só as escolas, mas as bibliotecas, as livrarias e os projetos editorais são instâncias que contribuem para o fomento da leitura.

Nos anos 1930, todavia, somente famílias abastadas e de centros urbanos como Rio e São Paulo podiam proporcionar às crianças esse cenário privilegiado. Presume-se que a maioria dos adultos fosse pouco proficiente na leitura e inapta para formar uma nova geração de leitores, posto que eram herdeiros de uma situação de rarefação de escolas e de um ensino que apresentava uma "grande distância entre o discurso pedagógico oficial e as condições de produção de conhecimento por parte daqueles que efetivamente ensinavam" (Idem, p. 115).

A leitura é também fortemente marcada pelo seu aspecto material: o livro, que enquanto objeto manipulável "pode influenciar na recepção da obra, na produção de significados, que variam no tempo e no espaço e acaba delineando o personagem para o qual se destina a obra - o leitor" (Idem, p. 66). Partindo dessa percepção de Silva, depreende-se que os editores não tinham em alta conta o público para o qual publicavam a literatura ligeira, pois os livros eram de baixa qualidade material. A impressão descuidada em papel ordinário apresenta muitos erros, como se pode ver em alguns exemplos pinçados em Gengis-Khan, da autoria de Hans Dominick e tradução de Manuel Bandeira ${ }^{38}$ :

Machnas [machinas] excelentes... Armamento insuperável (p.28)

Um repentino soavanco [solavanco] sacudiu a nave-patrulha (p.30)

Permaneceu immove [immovel] sentado (idem)

\footnotetext{
${ }^{38}$ Ortografia da época.
} 
Em Fisco [Frisco] o movimento operou-se de início com relativa calma. [...] Um calor abafado, sufocante, pesava sobre Frisco (p. 294).

Conforme ilustrado pelos trechos acima, o problema vai da falta à troca de letras, que, todavia, são falhas que não oferecem obstáculo para o entendimento da história. Ainda no livro Gengis-Kahn, o esquecimento de trechos do texto alvo no meio de um parágrafo em português é mais problemático, como ilustrado no trecho abaixo desprovido de sentido:

Um traidor o embaixador Tchung-Hu, abandonou o caro penhor [senhor] nas garras dos nossos inimigos... cajoled amid the Capuan delights of Livadia... ${ }^{39}$ (p. 194).

Vale ressaltar que a obra original foi escrita em alemão, mas esse exemplo leva a crer que Bandeira tenha utilizado uma versão inglesa. Essas falhas podem ter sido aceitas por se tratarem de obras sem importância, mas revela que não a revisão não era procedimento rotineiro. Aparentemente, os editores estavam mais preocupados com a aura de qualidade chancelada pelo prestígio do nome do tradutor que com o aspecto material da edição, que aparece em destaque nas capas chamativas, de apelo folhetinesco.

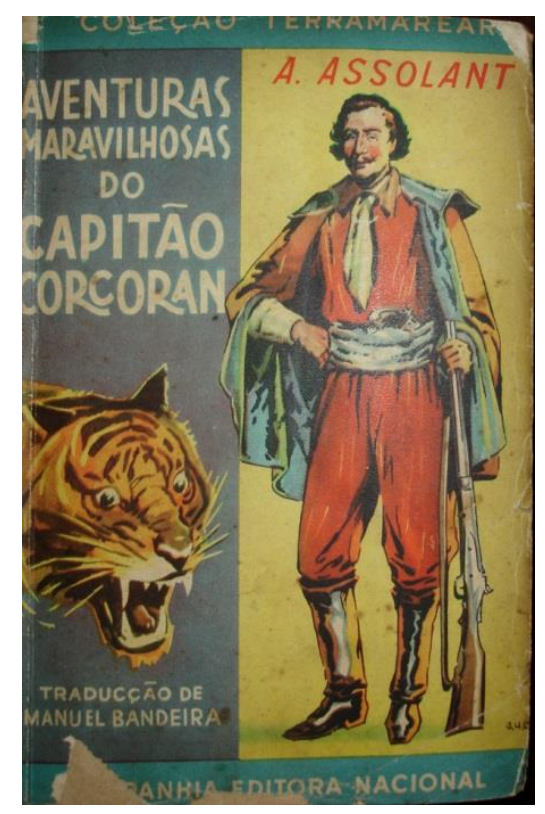

Figura 2: capa de livro

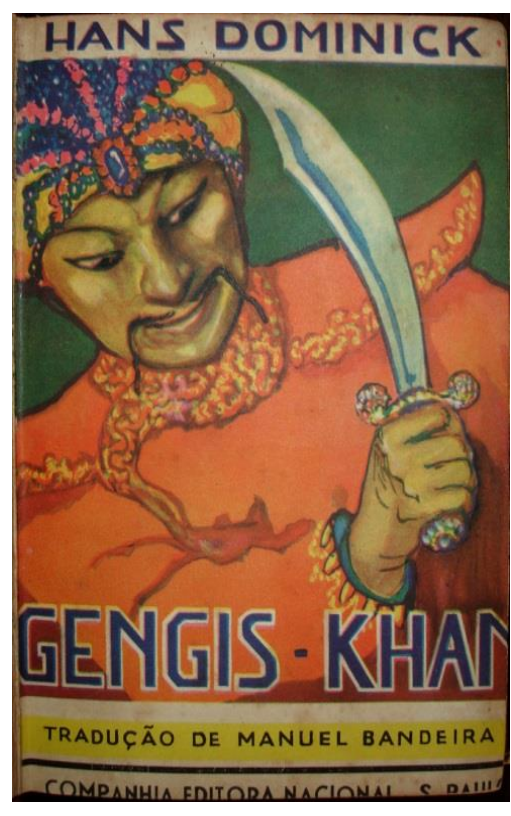

Figura 3: capa de livro ${ }^{40}$

\footnotetext{
${ }^{39}$ Grifo meu.

${ }^{40}$ Acervo particular.
} 
O recurso visual apela para o imaginário do leitor, prenunciando o tipo de história que está por vir e despertando sua curiosidade do leitor, como se pode observar nestas duas capas de livros da Companhia Editora Nacional, publicações de 1936, com tradução de Manuel Bandeira. O da esquerda, Aventuras Maravilhosas do Capitão Corcoran, é um romance de aventura de um original francês de 1867. O outro, Die Spur des Dschinges-Khan, é uma história de ficção científica alemã de 1922, mas a ilustração da capa e a redução do título podem levar o leitor a pensar que a obra se trata uma biografia do conquistador mongol.

Enquanto os escritores modernistas preconizavam uma literatura de caráter nacional, obras estrangeiras de diferentes gêneros vinham sendo traduzidas e publicadas, conquistando cada vez mais adeptos: romances de aventura, literatura infantil, suspense, romances água-com-açúcar. Muitos editores se renderam ao novo mercado: "É lamentável dizermos; porém o gênero policial é o que tem procura certa. Vamos, pois seguir a tendência, iniciando a nossa série policial ainda em princípios de 38", declara José Olympio (1939, p. 401), demonstrando desagrado em ter de abrir mão da literatura brasileira em favor da ficção estrangeira. Por sua vez, a estratégia de Henrique Bertaso, para o desenvolvimento da Editora Globo, era de fazer dinheiro com livros populares, para depois investi-lo na publicação de grandes obras: "Escrever, concluíamos, era um ato literário, artístico; publicar, um ato comercial ou industrial" (VERÍSSIMO: 2005, p. 36).

Manuel Bandeira, na crônica "O Brasil começa a ler" apesar de lamentar a baixa qualidade das obras, mostrava-se pragmático:

Os livros que vão fazendo verter do francês e do inglês nem sempre pertencem à melhor literatura. Pertencem antes à pior. Ai de nós! tem que ser mesmo assim. Num país onde a grande massa ainda não tem o hábito da leitura regular, é preciso criá-lo interessando-a com os romances de aventura [...]. Esses educarão os educáveis (BANDEIRA, 2009, p. 158).

A busca de soluções para a indústria livreira no Brasil por meio da popularização da leitura, todavia, já era preocupação dos editores do final do século 19, quando foi publicada uma diversidade de gêneros literários. "Todas essas publicações compuseram, ao longo dos anos, um heterogêneo arsenal de volumes expostos nas livrarias do Rio de Janeiro, prontos para atender às possibilidades de consumo de uma massa nascente e indistinta de leitores" (EL FAR, 2004, p. 108). 
No período do governo Vargas, todavia, as estratégias editorais se tornaram mais sistemáticas e eficazes favorecidas pelos projetos culturais e educacionais, pela criação de uma consciência profissional com o surgimento dos sindicatos e das leis trabalhistas e, paradoxalmente, pelo cerceamento da atividade literária por meio da censura.

\subsection{Livros ao alcance de todos: as coleções}

O Estado e os intelectuais "preocupados com o problema do livro advogavam a formação de leitores - facilitando o acesso a livros e assegurando a diversidade de leituras disponíveis - como meio de aceder à civilização" (DUTRA, 2013, p. 251). Muitas foram as iniciativas para expandir o consumo de livros: profissionalização de pessoal; regulamentação dos direitos autorais; adoção de novos padrões gráficos e estéticos; e ações de propaganda e comercialização, muito do mérito atribuído a Monteiro Lobato. Diante desse quadro animador Manuel Bandeira (2009, p. 235) comenta: "A Editora Nacional vem mostrar que o Brasil quer ler. Não lia porque o livro era caro. Aí por esse interior adentro o custo de um livro representava mais de dia de trabalho. Agora as modas mudaram". Outra novidade da editora é o lançamento de coleções, que viriam a atender todo tipo de leitor.

Tradicionalmente, as editoras dividiam as publicações em didáticos, poesia e literatura, esta sendo subdividida em ficcional ou não. Todavia, havia um tipo de leitura, que não sendo valorizada pela crítica, não podia ser classificada de literatura. Eram os almanaques, os folhetins e os romances "marginais", que não visavam um público específico, mas todos aqueles que gostassem de ler, independentemente de sua condição socioeconômica, conforme esclarece Alessandra El Far:

Quando um editor afirmava sua intenção de divulgar obras ao gosto do "povo", ele não estava se referindo às camadas pobres e de baixa renda. Seu desejo era, acima de tudo, extrapolar as fronteiras econômicas e sociais, que antes limitavam a compra de livros aos grupos endinheirados, a fim de expandir tal possibilidade a toda e qualquer pessoa livre das amarras do analfabetismo (EL FAR, 2009, p. 12).

A estratégia editorial adotada nos anos 1930 foi de ordenar o acervo subdividindo as obras em outras categorias visando um público específico. São lançadas as séries ou coleções em função do interesse do leitor e, também, da sua competência de leitura. Aproveitando-se da "consciência nacional que então despertava" (HALLEWELL, 1985, p. 360) são lançadas coleções com obras que discutem a 
realidade brasileira, como a "Documentos Brasileiros" e a "Brasiliana". Mas também, aproveitando outro nicho mercadológico, as editoras lançam gêneros mais voltados ao entretenimento.

De todos os gêneros publicados os romances tiveram um papel fundamental na expansão do público leitor, acessíveis não somente por causa do gênero, mas também pelo preço. Romances de aventura e fantasia, com histórias vertiginosas e impressão barata, como os de Júlio Verne, Alexandre Dumas e Ponson du Terrail, outrora eram consumidas às escondidas, como canta Mário de Andrade em Losango cáqui:

\author{
Meu pai com seu nariz judeu \\ Eu vivia quase sem ruído \\ Dumas Terrail Zola escondidos, \\ Se ele souber... Meu pai? Meu Deus?
}

Apesar de ser acusado de leitura imprópria para a formação intelectual da juventude, o folhetim, segundo Silva (2009, p. 212), "contribuiu para criar no leitor o 'hábito do romance', além de apontar campo de trabalho para os tradutores brasileiros". Na década de 1930, as aventuras folhetinescas começam a serem editadas na Coleção Terramarear, cujo nome já sugere histórias de piratas e expedições em lugares longínquos. Consequentemente, esse tipo de leitura passou a ser aceita por uma sociedade que buscava se modernizar e respondia às exigências da fantasia dos jovens, conforme observa Lêdo Ivo (1985, p. 52):

A Coleção Terramaear abriu para mim as suas imensas portas de maresia: e os piratas e as pirogas me levavam, por entre ondas altas, às paragens onde o mundo ao mesmo tempo começava com seu sol ofuscante e findava no cortejo de suas estrelas. [...] A brisa de evasão que eu, na adolescência e no pórtico da juventude, haveria de buscar em Baudelaire, Rimbaud, Mallarmé e Valéry, foi nessas páginas aventurosas que começou a soprar.

Nessa afirmação do poeta, nota-se que o pragmatismo mercadológico das editoras fomentou a formação de um público leitor, ainda não familiarizado com a literatura canônica. Em 1939, as publicações da Companhia Editora Nacional estavam totalmente organizadas em coleções que eram definidas pelo público que se pretendia atingir, ordenando o espaço de leitura. No catálogo da editora de 1939 constam 20 coleções diferentes, com paratextos que incentivam a leitura e cujo propósito é abranger mais público e superar as fronteiras sociais, culturais e econômicas (TOLEDO, 2004, p. $3)$. 
A Coleção Terramarear, que cativava a juventude, tinha sua equivalente para adultos: a Coleção Paratodos, "Apresentando os melhores romances nos gêneros de aventura, policial, histórico, é uma coleção popular, isto é, PARATODOS!". Essas publicações, não somente entretinham como também viriam a pavimentar o caminho para outras leituras mais complexas, também organizadas em séries, como Vidas Célebres e Obras Educativas.

O público feminino encontrava na Biblioteca para Moças, "A mais criteriosa coleção para moças, publicada em nossa língua". A necessidade de criar uma coleção exclusivamente direcionada à mulher deve-se ao fato de sua crescente presença junto ao público leitor. Lajolo e Zilberman (1996, p. 236) consideram que foi o surgimento da imprensa e o fortalecimento da escola que conferiram à mulher "a condição de sujeito diferenciado, marcado pela identidade de gênero".

Já para o "leitor iniciado", a Companhia Editora Nacional lançou a Biblioteca do Espírito Moderno, que selecionava “dentre as obras de aceitação pública aquelas que mais diretamente buscam condensar, esclarecer e popularizar a herança cultural". Para essa série, subdividida por assunto - filosofia, ciência, história e literatura - Manuel Bandeira traduziu As grandes cartas da história, de M. Lincoln Schuster, em 1942 e A vida de Shelley, de André Maurois, em 1941. A propaganda das séries era frequentemente veiculada na contracapa dos próprios livros.

O êxito mercadológico da literatura "ligeira", como se pode observar nos dados abaixo, acompanhou o desenvolvimento de outros entretenimentos de massa, como o rádio, o teatro de revista e o cinema, em uma sociedade cujo letramento não estaria completo. Nos dados abaixo sobre os livros publicados em 1933 pela Companhia Editora Nacional nota-se a preponderância das obras de literatura ligeira sobre os títulos mais clássicos. Também significativa é a cifra de livros didáticos, que evidencia a influência do programa de reforma educacional do governo: ${ }^{41}$

467.000 obras didáticas

429.500 literatura infantil (90.000 de autoria de Lobato)

107.000 literatura ligeira

82.100 belles lettres

\footnotetext{
${ }^{41} C f$. Hallewell, p. 277.
} 
O crescimento da indústria livreira fica evidente ao se contrastar o total de publicações acima com as 391.000 publicações em 1930 - 95 títulos incluindo as reimpressões - da mesma editora. (HALLEWELLL, 1985, p. 292). De 1938 a 1943, ${ }^{42}$ a ficção ocupou o primeiro lugar na análise das tiragens das seis maiores editoras (Companhia Editora Nacional/Civilização Brasileira, Globo, José Olympio, Francisco Alves, Melhoramentos e Irmãos Pongetti), com 748 obras de um total geral de 3239 exemplares, seguida pelos didáticos, com 702.

Entre os autores de ficção acham-se tanto os considerados canônicos pela crítica quanto os "clássicos" de aventuras, como Dumas, Fennimore Cooper, Defoe, Stevenson. Para suprir tantas coleções de gêneros distintos, as editoras recorreram à tradução de autores estrangeiros. Na relação de 49 títulos na contracapa de um livro da coleção Terramarear não figura nenhum nome de autor nacional. Monteiro Lobato, Manuel Bandeira e Godofredo Rangel foram os que mais traduziram para as séries da Companhia Editora Nacional.

Apesar de a estratégia das editoras de setorizar e popularizar as obras se mostrar eficaz, esses livros foram desprezados pela crítica por falta de "valor literário":

A história da literatura descartou tais livros e elegeu para o seu campo de estudo um conjunto de obras e autores, que nos dias de hoje passam a impressão de ter atuado de maneira isolada, sequencial e triunfante. Porém, ao lidarmos com o universo de letras é preciso perceber que esse quadro era muito mais complexo e difuso (EL FAR, 2004, p. 24).

Consequentemente, essas obras ditas populares dificilmente eram reeditadas e iam gradativamente caindo no esquecimento, não obstante a sua importância na formação do público leitor e a sua contribuição para a dinamização da indústria livreira, fatores que as tornam merecedoraa de estudo.

\subsection{O mercado da tradução literária}

A tradução literária no Brasil começou a ganhar impulso com as mudanças ocorridas em toda a atividade editorial no governo de Getúlio Vargas. Em fins do século 19 e começo do século 20, a tradução literária apresentava-se bastante incipiente, pois o

\footnotetext{
${ }^{42}$ Fonte: Anuário Brasileiro de Literatura. Rio de Janeiro. Irmãos Pongetti e Livraria Zelio Valverde. 1939, 1940, 1941, 1942, 1943.
} 
poder oligárquico era fortemente marcado pela cultura europeia. O poder coincidia com a elite intelectualizada que falante de outras línguas, principalmente francês, lia romances na língua original, conforme esclarece Wyler:

Talvez não seja absurdo afirmar que durante o século 19 os brasileiros se dividiam, grosso modo, entre aqueles que não liam traduções porque não sabiam ler e os que, sabendo-o, dispensavam a 'prótese' - donde a ausência de uma demanda que estimulasse o desenvolvimento da profissão de tradutor de livros (WYLER, 2003, p. 61).

Já no século 20, as escolas ainda mantinham as condições estruturais do império e somente uma minoria tinha acesso à educação. Somente um quarto das escolas era gerido pelo poder público ficando o resto por conta de instituições particulares que contratavam educadores vindos do exterior. Alice Koshiyama (1982, p. 36) relata que "a ação desses mestres estendeu-se, em algumas oportunidades aos órgãos governamentais, como a atuação de Miss Marcia Brown no Departamento de Instrução Pública de São Paulo, na gestão do Secretário Cesário Mota, do governo Bernardino de Campos". Consequentemente, por meio do aprendizado de línguas os alunos dessas escolas formariam um público leitor que não necessitava de tradução, mas muitos deles se tornariam tradutores na década de 1930.

Se a taxa de alfabetização da população em geral era baixa, a leitura também concorria com outros tipos de entretenimento de massa, como o teatro vaudeville, o cinema e o folhetim, que floresceu à margem do que se considerava literatura. $\mathrm{O}$ mercado consumidor de literatura traduzida era então incipiente, mas crescia à medida que se formava uma nova classe urbana. No entanto, a maioria das obras traduzidas era importada, sendo que uma grande quantidade de traduções era realizada em Portugal, pois os livros trazidos da Europa eram mais baratos e mais bem feitos do que os produzidos no Brasil (WYLER, 2003, p. 107). A importação movimentava o mercado carioca contentando os leitores ansiosos pelas histórias em voga na Europa.

Nos idos do século 19, a tradução como atividade no Brasil apresentava um caráter amador e diletante e "podia se apresentar como profissão disponível para o homem de letras ou, ao menos, como trabalho intelectual remunerado" (Lajolo, 2009 p. 97). Consciente dessa expansão, a Garnier, uma das grandes casas editoras da época, "montou sua equipe de tradutores, para competir com a concorrência lusa na publicação de folhetins de grande sucesso na França" (EL FAR, 2004, p. 38). Um dado que corrobora o pequeno nicho consumidor de literatura traduzida é o fato de a Garnier 
trabalhar com somente cinco tradutores, número que achava suficiente para o mercado do Rio de Janeiro, que à época representava o polo cultural do Brasil.

Com a deflagração da Primeira Guerra Mundial o comércio marítimo tornou-se arriscado, forçando a indústria livreira a buscar soluções "nacionais". Nessa expectativa, as publicações apareceram em formato barato e com enredo folhetinesco: dramas familiares, perda da inocência, aventuras. "Em razão disso, essas narrativas ganharam considerável diversidade e visibilidade no comércio literário da cidade. Assim sendo, os livreiros, além de comprar e revender as brochuras estrangeiras, começavam eles mesmos a traduzir [...]" (EL FAR, 2004, p. 74).

Nos início dos anos 1930, não obstante o despertar do interesse das editoras pelos autores nacionais, estes buscavam uma alternativa mais concreta de trabalho: tradução, jornalismo, ensino e crítica eram as opções que mais se aproximavam da criação literária, que estava longe de ser reconhecida como profissão. "Mas, se aos trancos e barrancos os autores iam encontrando formas menos insatisfatórias de remuneração, não se pode dizer que a profissionalização se estendesse de modo igualitário a todas as atividades letradas" (LAJOLO, 2009 p. 104).

Com relação ao predomínio do francês, se no século 19, os livros vindos da França ganhavam repercussão, graças à galicização de nossa cultura, a situação começa lentamente a mudar e a língua inglesa começa a ganhar espaço. Na década de 30, as editoras começam a lançar obras traduzidas de línguas até então menos prestigiadas, mesmo que muitas vezes tenham sido traduzidas de versões inglesas ou francesas. Érico Veríssimo atribui à Editora Globo uma parcela dessa mudança:

Foi graças a eles [livros editados pela Globo] que autores europeus de línguas anglo-saxônicas e germânicas foram postos ao alcance do leitor médio brasileiro. Até então o Brasil em matéria de tradução estivera quase exclusivamente voltado para autores franceses (VERÍSSIMO, 2005, p. 42).

Outras grandes editoras, como a José Olympio e a Nacional, que tinham em seus quadros de tradutores que eram escritores e poetas consagrados como Drummond, Guilherme de Almeida, Sérgio Milliet, Graciliano Ramos, e ainda representantes femininas das letras como Rachel de Queirós, Adalgisa Nery e Lúcia Miguel Pereira, por exemplo, também se interessaram em publicar tradução de ficção de outras línguas, além do francês, o que representou uma invasão de um campo que até então era quase monopólio da Livraria Globo (HALLEWELL, 1985, p. 375). Esses autores gozavam tanto da confiança dos editores que era dispensada a revisão de seus trabalhos e seus 
nomes apareciam nas capas, às vezes com maior destaque do que o do próprio autor. Tal era o prestígio desses escritores/tradutores que Veríssimo chamou-os de "escritores da Corte": "Apareciam na capital do país. Tinham, além de seu valor próprio, boa imprensa" (VERÍSSIMO, 2005, p. 37).

Mesmo sendo nome reconhecido no meio letrado, frequentemente, o escritor contratado não dominava o idioma do original. Wyler observa que:

O único problema era que a maioria só conhecia francês e, alguns, inglês, e com isso as obras de autores de línguas de menor difusão, como o russo, acabavam sofrendo as consequências das traduções que as mediavam e que já continham os cortes e acréscimos próprios daquelas culturas (WYLER, 2003, p. 113).

Muitas traduções não eram realizadas a partir do original. Érico Veríssimo (2005, p. 52) relata três casos. O primeiro é o do romance russo Guerra e paz, traduzido do francês por Gustavo Nonnenberg; também conta que ele mesmo utilizou uma versão inglesa para traduzir a obra alemã Kleiner Mann - was nun? publicada pela Globo com o título E agora, seu moço?(p 33). Por fim, menciona a tradução um livro de Erich Maria Remarque, provavelmente a partir da publicação espanhol e dividido entre quatro tradutores diferentes (p. 31). As versões espanholas parecem ter sido bastante utilizadas quando o tradutor não dominava a língua de partida. Mas, para Bandeira esse procedimento só dificultava, conforme relata a Mário de Andrade:

Traduzi um primeiro livro em alemão de um tal de Van der Velde sobre a aversão no casamento. Deram-me uma tradução espanhola com o original alemão - para ajudar. Mas logo verifiquei que o meu espanhol era veado. Basta dizer que de uma frasezinha alemã de duas ou três palavras (já me esqueci da diaba), cujo sentido apurei no Sachs-Villate que era "De acordo", o homem escreveu esta coisa incrível: "Allá, amigo mio! en esto no me meto!" Me lembrei de você naquele dia em que eu lhe dizendo "Os espanhóis são danados! traduzem tudo!", você temperou "Mal" ${ }^{43}$.

Manuel Bandeira, que aprendera alemão no Colégio Pedro II e retomara o idioma durante sua estada em Clavadel, Suiça, em 1913, relata como mais de uma década depois não necessitava do subterfúgio da tradução via outro idioma: "Bem, janeiro, fevereiro e março queimei as pestanas no alemão, o que foi bom, porque refresquei um pouco o vocabulário, de que eu já estava quase inteiramente esquecido" 44.

\footnotetext{
${ }^{43}$ Carta de MB a MA de 01/05/1934.

${ }^{44}$ Carta de MB a MA de 01/05/1934.
} 
Bandeira, ao lado de Lobato e Godofredo Rangel, foi um dos que mais traduziu para a Companhia Editora Nacional e Civilização Brasileira. O poeta como muitos de sua geração, falava francês, contudo, se considerava "bastante fundo em inglês" (BANDEIRA, 1996, p. 123). Avaliação incorreta na opinião de muitos, pois suas traduções de Elizabeth Barrett Browning e Christina Rosseti foram muito bem recebidas. Abgar Renault, poeta contemporâneo de Bandeira, assim avalia essas traduções:

São das páginas mais consideráveis de Manuel Bandeira as traducções de alguns poemas ingleses, que podem ser incorporados á sua obra como producção própria, sem embargo da fidelidade ao original, tal a assimilação e absorpção dos textos extrangeiros, da sua fórma, da sua technica e do seu espírito á fórma, á technica, ao espírito do traductor (RENAULT, 1986, p. 25).

Bandeira fez tanto da tradução poética quanto da prosaica uma atividade regular, mas a última era a que lhe complementava a renda. Apesar de remunerado, o ofício de tradutor ainda carecia de reconhecimento profissional, mesmo assim, muitos imprimiam seriedade à tarefa, conforme atesta Lobato (1957a, p. 328): "Ando a fiscalizar as traduções para Otales, ${ }^{45}$ e bom dinheiro perde ele com essa fiscalização [...] Prefere perder dinheiro a enfiar no público uma tradução que eu condene". Conforme já mencionado, Lobato não tinha grande consideração pelo público leitor da época e, por isso, achava que não valia a pena o editor gastar dinheiro com revisões.

$\mathrm{Na}$ primeira década do governo varguista, a intervenção estatal fomentou a atividade tradutória. John Milton (2008, p. 170) ressalta o fator econômico como responsável pelo grande número de traduções: "Minha hipótese é que as barreiras tarifárias na crescente economia protegida podem resultar em um aumento de traduções publicadas" 46. Segundo essa análise, as barreiras tarifárias se aplicavam tanto à importação de livros, traduzidos no exterior, como à de papel. Nenhum reparo a fazer a essa argumentação, no entanto, atribuir o desenvolvimento da tradução apenas às ações do governo, quer sejam de repressão quer sejam de incentivo, é uma visão reducionista de um cenário mais amplo. A deflagração da Segunda Guerra chamou a atenção do brasileiro para novas culturas e línguas. O envio de tropas da Força Expedicionária Brasileira para a Itália, que lutaram ao lado dos norte-americanos, foi um dos fatores que contribuiu para isso. Cláudio de Cicco assim analisa a questão:

\footnotetext{
${ }^{45}$ Octalles Marcondes Ferreira, diretor da Companhia Editora Nacional.

${ }^{46}$ My hypothesis is that tariff barriers in a protected growing economy can result in an increase in number of translations published.
} 
Soldados brasileiros e norte-americanos se confundiam numa só imagem do herói coberto de glória, de tal modo que cada vez mais o que era norte-americano era por inúmeras razões considerado no Brasil como sendo nosso. Nunca a América foi tão homogeneamente "americana" como após a vitória sobre os prestigiosos exércitos de Estados portadores de uma tradição muitas vezes secular (DE CICCO, 1979, p. 32).

O Brasil dos anos 1930 mostrava-se muito mais alinhado aos países do Eixo, sobretudo ao fascismo italiano, mas o governo de Getúlio Vargas teve de abandonar essa posição para juntar-se aos Aliados. Com a vitória destes, a cultura norte-americana passa a desempenhar um papel importante nos países do continente, mais do que os aliados do outro lado do Atlântico. Os Estados Unidos começariam a desenvolver uma política de aproximação com os outros países do continente americano, conforme relata Marly Tooge:

Herbert Hoover, presidente dos Estados Unidos de 1929 a 1933, foi quem primeiro utilizou a expressão 'good neighbor' ao executar uma viagem diplomática à América Latina, logo no início de seu mandato. Foi a semente do que se tornaria mais tarde a "marca registrada" do Governo de Franklin Delano Roosevelt e sua política de 'Boa Vizinhança', aplicada a partir de 1933 (TOOGE, 2011, p.52).

Tratava-se de uma política do governo dos Estados Unidos que, baseada no intercâmbio cultural e comercial, buscava a hegemonia em todo o continente, sem ter de fazer uso de uma intervenção declarada e agressiva. As traduções aconteceram nos dois sentidos: para o Brasil viriam obras americanas e para os Estados Unidos obras brasileiras, entre elas as de Jorge Amado. Entretanto, o papel do tradutor como construtor de representações e difusor de cultura não era devidamente reconhecido pela sociedade e os próprios tradutores/escritores não tinham "consciência de sua importância para as editoras e a difusão do conhecimento estrangeiro em nosso país" (WYLER, 2003, p. 115).

Despontando de forma preambular no início dos anos 1930, a tradução literária vai ganhando força e chega, na década de 40, à chamada "Idade de Ouro" da tradução (WYLER, 2003, p. 129). Com efeito, a Editora Globo começou "usando os tradutores que lhe apareciam, pois quem não tem traduttore de verdade, caça com traditore. $\mathrm{E}$ como apareciam traditori naquela época" (VERÍSSIMO, 2005, p. 30). Entretanto, a editora gaúcha foi, em 1942, a pioneira na organização de uma equipe de tradutores, com salário fixo e trabalho regular como plano de melhoria das traduções:

Só lá por princípios da década de quarenta é que nos foi possível pôr em prática o plano de "saneamento" de nossas traduções. [...] O processo de tradução de uma 
obra tornou-se então algo de muito elaborado. Escolhido o livro a verter-se para o português, procurava-se o tradutor, de acordo com a especialidade linguística de cada um (VERÍSSIMO, 2005, p. 45).

A "Idade de Ouro" da tradução desencadearia o processo de profissionalização, desvinculando a profissão de tradutor daquela de escritor e poeta e iniciaria a prática da crítica, inaugurada com a coluna de Agenor Soares de Moura no Diário de Notícias, em 1942.

O corpus de análise deste estudo, todavia, datam de 1934 e 1935, período em que se a atividade tradutória não apresentava mais o caráter diletante de outrora, ainda não se firmava completamente como profissão. Para Hallewell (1985, p.374) seria o declínio da produção literária nacional "devido à crescente esterilidade da vida cultural da nação sob o Estado Novo" que iria levar as editoras a publicarem autores estrangeiros. Eram autores em sua maioria não canônicos, mas cujas obras contribuíram com o desenvolvimento cultural brasileiro. Segundo Martins (1996, p. 148), tal volume de traduções "dava consistência à vida literária e, além da receptividade psicológica para os livros brasileiros, assegurava a consolidação da indústria editorial".

Apesar de a atividade tradutória ser exercida por homens e mulheres de letras, ou seja, "os responsáveis em qualquer cultura pela criação e reprodução dos padrões linguísticos do idioma" (WYLER, 2003, p. 117), não se desenvolveu, no período, nenhuma teoria sistemática sobre tradução. Obras que abordam a temática da tradução só surgiriam na década de 1950 como a pioneira Escola de tradutores (1952), de Paulo Rónai, seguida por Arte de traduzir (1954), de Brenno Silveira. De maneira geral, são obras de caráter prescritivo ou que por meio de experiências pessoais explica as questões de tradução. Segundo analisa John Milton (1993, p.172), “a maioria dos trabalhos sobre a tradução no Brasil não se interessou por ideias abstratas, mas pela tradução prática".

\subsection{Mais prática e menos teoria}

Entre 1930 e 1940, se por um lado não existia um profissionalismo per se da atividade, por outro a atuação de editoras como a José Olympio, a Globo e a Companhia Editora Nacional na publicação de obras traduzidas impulsionaria o que Lia Wyler (2005, p. 107) chamou de "tradução-indústria" devido à quantidade e à variedade de 
obras traduzidas: "Traduziam-se, portanto, muitas obras de ficção e muitas obras técnicas, para atender plenamente às necessidades de entretenimento e aprendizado do público brasileiro" (Idem, p. 115).

Mesmo com tal volume de obras traduzidas, não houve um movimento de caráter programático e nem teorizações a respeito da tradução por parte desses escritores/poetas que faziam as vezes de tradutor. $O$ que se encontra são reflexões pessoais sobre a prática, troca de conselhos e consultas sobre determinado aspecto, em prefácios, artigos e correspondências, que se referiam, na maioria das vezes, à tradução poética e não à prosaica. Cremos que essa primazia da tradução de poesia se deva a dois fatores, principalmente: o primeiro seria a projeção que a poesia teve durante o Modernismo e o segundo, o grande número de poetas, "que estrearam em torno desse divisor de águas [o movimento modernista] e continuaram a escrever" (BOSI, 1996, p. 385). Foram nomes de destaque nas letras e membros de uma elite cultural que também se dedicaram à tradução, quer seja como atividade complementar, quer seja para enriquecimento estético.

Mas, se muito foi discutido sobre a tradução poética, pouca atenção foi dada à tradução de prosa. Mário de Andrade no artigo "Tradutores Poetas", publicado no Diário de Notícias, do Rio de Janeiro, em 1945, assim compara a tradução de poesia com a de prosa:

Imaginando outro dia sobre os problemas superficiais da tradução poética, eu acabei chegando a uma verificação desconcertante que eu mesmo não esperava. Não há dúvida que são mais numerosas no mundo as traduções célebres de poesia que as de prosa! No Brasil isso se prova fácil, e nada existe em nossa tradução prosística que se possa comparar às traduções poéticas. As ótimas traduções poéticas se acumulam [...]. Ora eu estava na mansidão destas imaginações quando me seguiu no pensamento este decreto: A tradução em prosa é mais difícil que a tradução de poesia, que absurdo! (ANDRADE, 1984, p. 179) ${ }^{47}$.

O "decreto" de Mário de Andrade pode ser compreendido lembrando que a forma poética dominou a geração modernista, mesmo que os poetas dessa geração também tivessem produzido prosa e que a tradução de poesia requeria a habilidade de um poeta por apresentar aspectos considerados intraduzíveis. O escritor, porém, não se furta de condenar a tradução de algumas obras "verdadeiramente grandes" da literatura estrangeira: "Na maioria deles a tradução é uma vulgaridade, de uma chatice larvar; em

\footnotetext{
${ }^{47}$ Grifo meu.
} 
não poucos é péssima. Raros são os francamente bons" (ANDRADE, 1993, p. 96) e aconselha que "entre o belo e o útil", se traduza, no momento, mais o útil.

Abre-se aqui um parêntese para a avaliação de Alceu Amoroso Lima (1956, p. 80) que talvez possa elucidar essa postura de reverência com ralação à linguagem poética e, consequentemente, à sua tradução: "A prosa da primeira geração modernista foi mais fraca que a poesia. Os poetas dessa geração também escreveram romances e páginas em prosa, mas, em geral, foi a poesia a forma poética que então dominou".

Da mesma maneira, Manuel Bandeira parecia valorizar a tradução de poesia em detrimento da de prosa, como se pode deduzir pelas considerações em duas cartas do poeta a Mário de Andrade. Na primeira, comenta a dificuldade em traduzir o poema de Goethe Selige Sehnsucht: "Uma poesia de Goethe filha da puta para pôr em verso português. [...] Me diga se em conjunto está muito escroto o que fiz. E olhe que só rimei os segundo e quarto versos!" ${ }^{48}$. Mas, em carta subsequente, datada do mesmo dia, concluiria que a tradução do poema não necessita tanto empenho uma vez que era citado em obra de literatura "menor": "A coisa não tem grande importância, pois se trata de uma citação no texto da obra que estou traduzindo (Van der Velde, Die Abneigung in der Ehe). Em todo caso não queria fazer feio" ${ }^{49}$.

Dessa observação se pode depreender que a tradução do poema deveria atender às necessidades de um público supostamente não erudito, mas também não macular a reputação do tradutor, uma vez que seu nome constaria na folha de rosto. Interessante o fato que Bandeira, posteriormente, inclui a tradução desse poema, sob o título Anelo, em Poemas Traduzidos, com pequenas diferenças de pontuação, léxico e a supressão da última estrofe.

Manuel Bandeira comenta e refere-se à tradução de poesia muito mais frequentemente que à de prosa. Experiente, o poeta assim aconselha seu afilhado, Alphonsus de Guimaraens Filho no caso da tradução de um poema do norte-americano Eaton:

Mas peço licença para lhe dar uma lição: sempre que você quiser traduzir um
poema faça um estudo preliminar no sentido de apurar o que é essencial nele e o
que foi introduzido por exigência técnica, sobretudo de rima e métrica. Isto feito,
se aparecerem dificuldades que digam respeito ao último elemento (o que não é
essencial e o que pode ser alijado), resolva-as alijando o supérfluo mesmo que seja

\footnotetext{
${ }^{48}$ Carta de MB a MA de 16/12/1933.

${ }^{49}$ Carta de MB a MA de 16/12/1933.
} 
bonito. É o caso de beautiful and wise. Lindo sem dúvida, mas dispensável, já que intraduzível (ANDRADE \& BANDEIRA, 1974, p. 96).

O caráter valorativo atribuído à tradução poética parece advir do prestígio da poesia enquanto arte, o que eleva a tradução poética à qualidade de exercício autoral por engendrar um "processo de substituição", segundo os termos de Mário de Andrade:

O que o tradutor faz é substituir um objeto por outro, apenas observando do primeiro, para efeitos da substituição, o elemento funcional (o assunto) e as suas consequências estéticas (realização técnica). O segredo na substituição poética, não é tanto preservar o assunto, que, exemplificativamente, consistiria apenas em substituir um vaso por um vaso, e não um abajur. O importantíssimo, o definitivo é a substituição das consequências estéticas, porque nelas é que se contém o estado da sensibilidade em que o poeta definiu o assunto, e os elementos de beleza utilizados para nos convencer (ANDRADE, 1984, p. 179).

Para os poetas que traduziam poesia, a maneira de suplantar a intraduzibilidade seria a recriação, que quando bem sucedida era bastante valorizada, conforme atesta Drummond (1984, p. 47) comentando o trabalho de Abgar Renault: "Rigorosamente Abgar não traduziu os poemas, fê-los de novo. Têm a serenidade, a compassada beleza, o sentimento sutil da língua, que há do nosso caro e esquivo poeta. Entretanto, são também ingleses, e são principalmente poesia”.

Abgar Renault, por sua vez, apresenta uma definição de tradução poética que beira o esotérico:

Traduccção, especialmente traducção de poesia, é interpretação, é incorporação, é assimilação, penetração que vá além do corpo vocabular e atinja, certamente, a carga emocional, que cada palavra só possue no contexto e pelo contexto em que se ache encerrada, associada ás demais e com ellas intimamente syntonizada. Numa palavra: traduzir é crear de novo (RENAULT, 1986, p. 25) ${ }^{50}$.

Na esteira dessa mesma ideia de tradução como um processo de recriação, Mário de Andrade (1984, p. 177) utilizaria também o termo transposição, ao comentar a tradução feita do seu poema Sambinha por Hilde Koswan:

São excelentes transposições para o alemão, e nem compreendo outro processo de tradução de Poesia. Toda a intenção, todo o espírito que busquei pôr nas minhas poesias, está admiravelmente expresso no seu alemão, com uma delicadeza de tato e um apropositado de termos que me encantam.

Bandeira (1978, p. 293), para quem "há poemas traduzíveis e poemas intraduzíveis", a recriação, também, seria o caminho a ser seguido, a fim de poder

\footnotetext{
${ }^{50}$ Ortografia original.
} 
"achar em outra língua a mesma virtude musical em outra combinação de palavras", pois "a tradução de um poema é, afinal de contas, uma recriação. Assim que ela só é total e perfeita quando sai fiel ao poeta traduzido e fiel ao poeta tradutor" (Idem, p. 229). Ao "recriar" um poema na tradução, Bandeira se preocupava com a fidelidade da informação, mas sem deixar de lado a preocupação com os aspectos formais:

Recebi a encomenda de traduzir Mireille. Mas vou por de lado as rimas para ficar mais fiel ao sentido original. Conservarei a estrofe e os metros: já é música bastante para esse poema cujo defeito para mim está precisamente na sua excessiva musicalidade, ou melhor, melodiosidade ${ }^{51}$.

Assim conclui-se que para os poetas do período a tradução de poesia devia ser de caráter autoral, como fica explícito neste comentário de Bandeira com relação a dois sonetos de Elizabeth Barrett Browning traduzidos: "Essas traduções me agradam, porque creio que fiz coisa minha, não acha? Assim que gosto de tradução: como a mulher de Verlaine: ni tout à la fait la même, ni tout à fait une autre" ${ }^{52}$.

Já na tradução de prosa não se concediam tais liberdades autorais, pois, segundo Mário de Andrade (1984, p. 181), a prosa de ficção também teria uma "exigência de sua realização estética" que se acharia em segundo plano, pois a importância do assunto se impõe. Mesmo assim, esse poeta criticou alguns tradutores de prosa que "se limitam a por em gramática as obras que traduzem, quando tinham que por em estilo”. O poeta, todavia, não esclarece sua concepção de estilo. Seria o estilo do autor ou o do tradutor? Qualquer que seja a resposta, o tradutor desse período se depara com a eterna dicotomia fiel/livre. Sérgio Milliet (1984, p.187) protesta: “Ao tradutor fiel acusam de não dar elegância a um texto pesado e medíocre; ao tradutor livre censuram a infidelidade".

As eventuais críticas sobre tradução da época, de caráter judicativo e avaliativo, engendrariam o modus operandi de algumas editoras. A Livraria Martins Fontes anunciaria a sua coleção "Biblioteca Histórica Brasileira", com obras traduzidas dos relatos dos viajantes estrangeiros numa "cuidadosa seleção de títulos" em "traduções fiéis e integrais" (HALLEWELL, 1985, p. 415). Veríssimo assim descreveu o procedimento adotado pela Globo:

Depois que o tradutor dava por terminado o seu trabalho, os respectivos originais
eram entregues a um especialista da língua de que o livro fora traduzido, para que
ele confrontasse, linha por linha, com o original, procurando verificar a fidelidade
da versão (VERÍSSIMO, 2005, p. 46).

${ }^{51}$ Carta de MB a Alphonsus de Guimaraens Filho de 03/07/1961.
${ }^{52}$ Carta de MB a MA de 17/071929. 
Nessa época, a ideia de qualidade era resultado de fidelidade ao texto fonte no que diz respeito à tradução de prosa. Brenno Silveira $(1954$, p. 8) conta que ao ser contratado pela Globo como chefe do escritório de tradução em São Paulo recebeu a orientação de que deveria exigir três coisas de seus tradutores: fidelidade, fidelidade, fidelidade e, ainda, que deveria lembrar-se de que tradutor não é autor, tampouco coautor da obra sendo que sua tarefa era a de passar para o português "da maneira mais fiel possível tudo que está escrito no original", não poderia editar, modificar, omitir ou acrescentar nada. Mesmo com essa "camisa de força" que a editora impunha a seus tradutores, Érico Veríssimo confessa a infidelidade com um texto de Edgar Wallace, pois era um autor que ele desprezava:

Estava eu a traduzir o On the Spot, de Edgar Wallace, quando movido pelo tédio quase mortal que livro me produzia, resolvi colaborar com o autor e tomar liberdades com o texto, respeitando a estória mas modificando o estilo. Fiz o diabo. Será demasiada pretensão afirmar que em português ficou melhor que o original? Acho que não [...] (VERÍSSIMO, 2005, p. 41).

Não era a primeira vez que Veríssimo traduzia Wallace a contragosto. Esse escritor, que em 1931 começou a traduzir livros do inglês para complementar sua renda, relata: "O primeiro que me caiu às mãos foi desgraçadamente uma novela policial de Edgar Wallace, The ringer. [...] $\mathrm{O}$ autor e a história não me interessavam" (VERÍSSIMO, 1987, p. 247). A pouca consideração do tradutor pela qualidade literária da obra valida sua transgressão às normas da editora. Manuel Bandeira também traduziu Wallace e pela rapidez com que completou a tarefa parece não ter tido maiores preocupações com o trabalho. Escreve Bandeira a Mário de Andrade em $1^{\circ}$ de maio de 1934: "Em abril peguei um romance do Edgar Wallace, que acabei ontem".

Em oposição à exigência de fidelidade, a "melhora" do texto foi bastante louvada quando Manuel Bandeira já gozava de um bom nome como tradutor. O maior dilema com respeito à "fidelidade" ao texto transparece no sentido inverso, quando da versão para o inglês das obras modernistas. Mário de Andrade se preocupou quando surgiu a oportunidade de traduzir o Macunaíma para o inglês: "Não creio que ela [Margareth Richardson] consiga reproduzir a essência poema-heróico-cômico do livro". Parece que Mário tinha seu texto em alta conta, pois prosseguiu: "Li o Domitila que ela traduziu e 
me pareceu coisa falada. No que, aliás, tem-se que dizer que ela inda melhorou o Setúbal" ${ }^{53}$. O livro de Mário seria superior ao de Setúbal?

Três anos mais tarde, quando saiu a tradução de Amar, verbo intransitivo, com o título de Fräulein, Mário ao saber das modificações feitas pela tradutora, com o propósito de o livro ficar mais palatável e vendável nos Estados Unidos, reclamou: "Parece que ela deformou muito certas coisas e isso me traz meio divertidamente assustado" "54. Para Mário de Andrade, então, a intervenção do tradutor tanto pode "melhorar" quanto "deformar" o texto, numa avaliação totalmente subjetiva, subordinada ao seu gosto pessoal.

Após tantas observações a respeito da tradução fica a dúvida, emprestada do título de um artigo de Rosemary Arrojo: A que são fiéis os tradutores da década de 30? Com relação à poesia, a fidelidade torna-se quase metafísica na busca pela "essência" do poema. Na prosa, aparentemente, a mensagem se impõe, mas paradoxalmente se permite a intervenção do tradutor no texto, cuja aceitação varia segundo uma avaliação subjetiva, influenciada pelo prestígio do tradutor. Mesmo que esses tradutores não tenham pensado em termos teóricos suas reflexões mostram o terreno escorregadio de conceituação que é a área de tradução.

\footnotetext{
${ }^{53}$ Carta de MA a MB de 12/12/1930.

${ }^{54}$ Carta de MA a MB de 06/8/1933.
} 


\section{PROLEGÔMENO DE CONCEITOS E MÉTODO}

I keep six honest men (they taught me all I knew). Their names are What and Why and When and How and Where and Who.

Rudyard Kipling

\subsection{Romance de aventura e literatura infanto-juvenil}

O romance de aventura surge no rastro das narrativas dos grandes exploradores do século 19 e se constitui de histórias de cunho fictício, que não se preocupam com a verossimilhança, uma vez que a distância temporal e geográfica permite toda sorte de exagero. Nesse tipo de romance, conforme ressalta Massaud Moisés (1967, p. 298), "o enredo ocupa lugar prevalente no corpo da obra; a ênfase é posta sobre os acontecimentos, os episódios" que se sucedem linearmente. Em decorrência do gênero, e/ou visando um suposto público menos letrado, a narrativa é construída com linguagem simples e direta, evitando períodos muito longos e figuras de linguagem, e de estilo, elaboradas.

Em todo tipo de ficção, a linguagem dá vida às personagens envolvendo os leitores de tal forma que desperta neles sentimentos e emoções, mesmo estando eles cônscios do que é vida real e do que é ficção. Beth Brait (2000, p. 11) ressalta dois enunciados do Dicionário enciclopédico das ciências da linguagem, organizado por Oswald Ducrot e Tzvetan Todorov, que são fundamentais para diferenciar a pessoa real do ser ficcional: "O problema da personagem é, antes de tudo, um problema linguístico, pois a personagem não existe fora das palavras; as personagens representam pessoas, segundo modalidades próprias da ficção". 
No romance de aventura, as personagens se desprendem da realidade e parecem inverossímeis, mas fazem sentido no âmbito da realidade ficcional apresentada. Essas personagens são planas, pois são construídas ao redor de uma só ideia ou qualidade, e sem densidade psicológica, não evoluindo no transcorrer da narrativa. Frequentemente, sua caracterização é realizada por um narrador onisciente neutro, que como uma câmara as apresenta e as descreve para o leitor em um registro contínuo. O herói do romance de aventura, em condições precárias de sobrevivência, está sempre se confrontando com situações extraordinárias, as quais ele domina com coragem, força e astúcia. O protagonista é singularizado por suas qualidades e virtudes e seus antagonistas pelos defeitos e vícios, com risco de serem caricaturais, mas são "autênticos" quando julgados pela verossimilhança interna da obra.

A linguagem caracterizadora da construção da personagem é um aspecto tão dominante no romance de aventura quanto aquela caracterizadora do espaço. A narrativa se ambienta em lugares exóticos e distantes segundo representações construídas pelo colonialismo europeu. Nesse cenário imaginado, como o continente africano ou o oriente, transcorre a aventura marcada pelo constante deslocamento físico do protagonista, resultando em uma sucessão de eventos e coincidências: "A história, nesse caso, ganha em vivacidade e dinamismo, e perde em concentração" (MOISÉS, 1967, p. 177). O acaso é recurso utilizado com frequência pelos romancistas nesse tipo de narrativa e a trama brinca com a imaginação do leitor, que realiza o desejo de "viver" perigosamente por meio da narrativa. Lobato em carta a Godofredo Rangel relata a impressão que a leitura de histórias de aventura do Journal de Voyage lhe causava - um misto de fascínio e medo:

Eu ouvia gritos... E coisas horrorosas da Índia. Viúva na fogueira. Elefantes esmagando sob as patas a cabeça de condenados. E tigres agarrados á tromba de elefantes. E indios da Terra do Fogo, horríveis, a comerem lagartixas vivas. E eu via a lagartixa bulir... E tragedias do centro da Asia e lá das Guianas. O rio Orinoco me impressionava muito. Eram os romances de aventuras de Gustave Aimard e Mayne Reid (LOBATO, 1957a, p. 51).

Os heróis são fantásticos, os lugares irreais, as aventuras impossíveis, "mas é inegável a magia com que os livros se apoderam dos leitores, acorrentando-os ao interesse da narrativa, arrebatando-os de volume em volume, interminavelmente", segundo A poetisa Cecília Meirelles (1984, p. 94), que também se dedicou ao estudo da literatura infanto-juvenil. Segundo Leonardo Arroyo, tais obras, "historicamente quase 
sempre indistintas da literatura popular", tornaram-se por meio da tradução clássicos da literatura infantil e exemplifica:

É possível, neste particular, que se possa apontar como das mais antigas traduções aparecidas em português, como obra endereçada à infância e adolescência, o Robinson Crusoe, de Daniel Defoe. Isto se dava em 1786 em Lisboa, na tradução de Henrique Leitão de Sousa Mascarenhas [...] De 1822 é também uma tradução das Viagens de Gulliver, de Swift, em vários volumes. Foi impressa em Lisboa e traduzida por autor que apenas se identifica com as siglas J.B.G. (ARROYO, 1990, p. 99).

No Brasil, esses romances em princípio destinados aos adultos iriam despertar o interesse dos jovens levando a uma reflexão sobre a necessidade de uma produção exclusiva para eles, ainda que de maneira incipiente, conforme observa Nelly Novaes Coelho:

O século XIX é chamado de século de ouro do romance e da novela - formas literárias utilizadas, durante muito tempo, como a mais importante fonte de entretenimento para o grande público de todas as classes [...] É também neste século que aparece a consciente preocupação com a literatura de ficção para crianças (COELHO, 1981, p. 279).

A literatura infanto-juvenil no Brasil anterior ao século 20 consistia na apropriação das histórias do folclore europeu e na tradução e adaptação dos clássicos, principalmente edições portuguesas de original ${ }^{55}$ francês, um exemplo de "aproveitamento de obras literárias fundamentais em reduções criteriosas" (MEIRELES, 1984: 123). As "reduções criteriosas" que tinham por objetivo atingir um público menos competente em leitura viriam, assim, promover um gênero, encontrando-se na gênese da literatura infanto-juvenil brasileira: "Toda essa enorme massa de traduções lida durante o século XIX no Brasil criou condições, sem dúvida, para o próprio aparecimento da literatura infantil brasileira em suas mais fortes e definidas características" (ARROYO, 1990, p. 101). Decorre que a tradução abriu as portas não só para uma literatura infantil de características próprias, livrando-se da mediação portuguesa, mas também foi fator de iniciação na leitura para muitos adultos também.

A cultura não divide a sociedade em faixas etárias, sendo o "leitor jovem" uma categoria inventada pelo mercado que irá segmentar o público leitor formando novos gêneros, ou subgêneros, literários. Partindo dessa premissa, não se deve desprezar também a relação entre a publicação de tradução e os aspectos econômicos em um

\footnotetext{
${ }^{55}$ Ignorarei neste trabalho o conceito de "original" como já foi discutido em alguns momentos com relação à tradução e considerarei "original" o texto fonte do qual se fez a tradução.
} 
período em que o país passava por transformações de ordem social, política e econômica. Milton (2008, p. 163), inclusive propõe que "fatores econômicos podem ser incluídos no modelo de polissistema de Itamar Even-Zohar e no conceito de normas, conforme proposto por Gideon Toury" 56 .

A década de 1930 prenuncia uma prática editorial, que se consolidará no fim do século, de estratificar o público leitor segundo uma projeção do que seria adequado à faixa etária, ao sexo e ao nível intelectual, lançando um grande o número de traduções em coleções. Dessa prática resulta que os romances de aventuras migrariam do público adulto para o jovem e entrariam no sistema literário infanto-juvenil brasileiro pela tradução. Como as obras de Daniel Defoe, Walter Scott, Alexandre Dumas e tantos outros, Tarzan, de Edgar Rice Burrouhgs alcançou grande sucesso entre o público adulto americano, mas por suas características de romance de aventura e por ser incluída na coleção Terramarear com o apelo: "Não basta aprender ler. É preciso que o menino leia! Livros especialmente feitos para os meninos, para a juventude em geral", difundiuse entre os leitores mais jovens. A editora predetermina o público e segmenta a produção editorial, um recurso que a indústria editorial e o mercado leitor ainda incipiente utilizaram para se ordenar.

Mesmo que estudos escrutinem a questão, a delimitação em faixa etária é sempre arbitrária e mediada por diversas instâncias. A primeira delas é da própria imagem que o autor tem do leitor jovem. A esse respeito, Cecília Meireles comenta:

De modo que, em suma, o "livro infantil", se bem que dirigido à criança, é de invenção e intenção do adulto. Transmite os pontos de vista que este considera mais úteis à formação de seus leitores. E transmite-os na linguagem e no estilo que o adulto igualmente crê adequados à compreensão e ao gosto do seu público (MEIRELLES, 1984, p. 30).

Some-se à do autor, a intenção do editor, que tem os olhos voltados para o mercado, e a do tradutor, que possivelmente ao perceber uma possível desvalorização do gênero tem o público alvo em menor conta e se permite uma liberdade que não ocorreria no caso da obra canônica. João Azenha Junior aponta, além da questão mercadológica, a escola como agente cerceador da autonomia da literatura para jovens como gênero:

\footnotetext{
${ }^{56}$ Economic factors can be included in the polysystem model of Itamar Even-Zohar and the concept of norms, as proposed by Gideon Toury.
} 
A essa dificuldade de legitimação somam-se, no desenrolar da história mais recente, duas outras relações de dependência importantes: a primeira é a dependência da escola, visto que a habilidade de ler é entendida como pressuposto para a leitura e vem associada ao crivo da proposta de educar, de preparar a criança para o mundo; a segunda, diz respeito aos ditames do mercado editorial e livreiro, para os quais o livro infantil é objeto negociável e comercializável (AZENHA, 2008, p. 98).

Conforme já mencionado, nos anos 1930 a Companhia Editora Nacional é uma das empresas que definem o leitor por meio do lançamento das séries. Tarzan é destinado aos jovens; todavia, a escola não endossa tais leituras. O status do romance de aventura nos anos 1930, além de ambíguo com relação ao público alvo, é marcado pela condição de marginalidade resultante do desprezo da crítica, pela ausência do caráter pedagógico e pela sua condição de tradução, ou seja, de inferioridade, conforme observamos em algumas declarações de escritores/tradutores e editores citadas no capítulo anterior.

Com relação à década de 1930, se já seria arriscado estabelecer os limites entre literatura infantil e adulta de forma taxativa, mais difícil ainda seria a diferenciação de juvenil do infantil. Segundo Ceccantini e Pereira (2008, p. 8), somente no depois de 1950 é que a literatura enveredou "por um terreno vago, impreciso e mítico, que tem sido denominado 'adolescência' fase plena de tensões associadas a um período comprimido entre a infância e a idade adulta, o que lhe confere uma instabilidade peculiar". O conceito de juventude como é entendido hoje está relacionado às questões históricas, às demandas de mercado e à estratificação da educação. Nos dias atuais, segundo o jornal Folha de São Paulo ${ }^{57}$, a literatura para jovens e crianças é o "segmento que mais cresce no mercado editorial mundial". As editoras criam subdivisões do gênero infanto-juvenil como 'jovem adulto' (13 a 18 anos) e 'adulto novo' (18 a 25) numa classificação controversa, que não mais tem como pré-requisito a competência e o conhecimento de mundo do leitor, mas o estabelecimento de um nicho de mercado.

Contudo, a divisão do gênero baseada em idade não se mostra suficiente para definir suas características precípuas "conferindo-lhe uma instabilidade particular da qual não é qualquer esforço interpretativo que consegue dar conta" (PEREIRA \& CECCANTINI, 2008, p. 9), conforme já mencionado com relação à trajetória dos romances de aventura. Independentemente da problemática da divisão em várias faixas

\footnotetext{
${ }^{57}$ Ilustrada, Folha de São Paulo, E1, 14/12/2013.
} 
etárias, Azenha (2005, p. 370) consonante com o pensamento de Cecília Meirelles, observa que a assimetria reside entre "a instância de produção do texto e a instância de recepção", incluindo a tradução na sua reflexão:

Decorre daí que no processo de criação da literatura para a criança e o jovem, trata-se, de um lado, da intepretação que o autor faz do mundo dentro do texto e, de outro, da imagem de criança formada na cabeça do escritor. No caso da tradução desse gênero de literatura, trata-se, pois, de uma dupla projeção: na recepção do texto a traduzir, a interpretação do tradutor pode convergir para essa criança imaginária e para seu mundo (também imaginado), ou então divergir (AZENHA, 2008, p.100).

No caso da tradução de Tarzan, além da dupla projeção mencionada acima, ainda há o deslocamento do público alvo, que originariamente era o adulto, para o jovem. Em resumo, quem escreve se dirige ao adulto e quem publica visa o jovem, tentando impor do que a criança deve gostar de ler. A assimetria envolve ainda uma relação entre línguas, entre culturas e entre autores (o original e o tradutor), mediadas pelo tradutor e pelo editor que o contrata e que seleciona as obras predeterminando o público ao ordená-las em séries. Consequentemente, mesmo que o tradutor esteja no fulcro do surgimento do romance de aventura no Brasil, principalmente na década de 1930, o texto traduzido só se realiza por força de um aparato que o completa e o divulga.

Monteiro Lobato defendia a tradução, que trouxe a público obras onde "ha descampados e florestas imensas, montanhas, planuras de neve, tigres e panteras e elefantes. Que ha perspectivas, em suma, e ar livre" (1955c, p. 322), e ressalta a sua importância para a cultura nacional:

A literatura dos povos constitue o maior tesouro da humanidade, e povo rico em tradutores faz-se realmente opulento, porque acresce a riqueza de origem local com a riqueza importada. Povo que não possue tradutores torna-se fechado, pobre indigente, visto como só pode contar com a produção literaria local. (Idem, p. 128).

Ao considerar a tradução como parte integral da cultura receptora, o modelo de estudo passa a ser orientado pela contextualização e pelos elementos circunstanciais que a condicionam. Dessa maneira, a problematização da questão do estilo na atividade tradutória da série Tarzan neste trabalho deverá ser efetuada considerando-se as várias instâncias que envolvem a sua presença no Brasil, tendo em mente, além da questão linguística, sempre presente no processo tradutório, o ambiente literário alvo e o seu momento histórico. 


\subsection{Literatura canônica versus literatura de entretenimento}

Além de ser problemático delimitar a faixa etária a que o romance de aventura se destina, também há muita discordância quanto à tipologia e sua relação com o cânone, por isso esta seção discutirá o conceito de obra canônica em oposição ao de literatura de massa.

A expressão "literatura de massa" é uma das manifestações culturais, "produzidas segundo as normas maciças da fabricação industrial". Esses termos utilizados por Edgar Morin (1967, p. 16) podem parecer exagerados para o contexto brasileiro da década de 1930, mas ao se comparar o desenvolvimento da indústria livreira do período com o passado e ao se observar a maneira como Lobato considerava essa atividade, a definição é adequada, pois passando de escritor a editor ele "criou novas perspectivas para uma verdadeira divulgação das edições nacionais, com a adoção prática e generalizada de sua ideia de anunciar comercialmente a produção literária" (LIMA, 1985, p. 60), com sistema de vendas diversificado: em consignação nas livrarias, por atacado ou pelo reembolso postal.

A cultura de massa é produzida em larga escala, visando um grande público que vai conhecê-la através de meios de difusão os mais diversos, lembrando novamente Monteiro Lobato que enviou cartas a estabelecimentos comerciais oferecendo livros como mercadoria. A literatura enquanto manifestação cultural de massa, paradoxalmente, além de obedecer a uma padronização deve manter sua individualidade e para tal os romances, divididos em coleções, seguem uma fórmula para se adequar ao grande público, ou seja, "a todos e a ninguém, às diferentes idades, aos dois sexos, às diversas classes da sociedade", conforme argumenta Morin (1967, p. 37). Todavia, a intelligentsia, com sua concepção elitista da cultura, se opõe a eles.

Apesar de esse gênero de literatura ser menosprezado no meio intelectual, o impacto que a tradução dos romances de aventura teve na formação da literatura brasileira para o público jovem não deve ser minimizado. Esse processo de um gênero marginal passar a ocupar um lugar central na literatura infanto-juvenil receptora remete aos estudos de Itamar Even-Zohar e seu conceito de polissistemas, que abarca todo o conjunto de produções literárias, desde a literatura canonizada até as manifestações literárias consideradas mais marginais. 
Even-Zohar (1990a, p. 193), além de afirmar ser a tradução literária um sistema integral dentro do polissistema literário, considera-a também o sistema mais ativo, pois ele participa na formação do centro uma vez que é parte de uma força de renovação. Mas, o teórico adverte:

Está claro que justamente os próprios princípios de seleção das obras a serem traduzidas são determinados pela situação vigente no polissistema (nacional): os textos são escolhidos conforme a sua compatibilidade com as novas abordagens e com o papel supostamente inovador que estes assumirão dentro da literatura alvo ${ }^{58}$ (EVEN-ZOHAR, 1992, p.193).

Partindo da reflexão de Even-Zohar, pode-se afirmar que a tradução sistemática de obras de literatura de entretenimento, publicadas em coleções visando um público específico, vai contribuir para formação de "um novo repertório" de um sistema literário 59 ainda não consolidado no Brasil, o da literatura infanto-juvenil. Por outro lado, se esse tipo de literatura visasse o leitor adulto, manter-se-ia em situação periférica segundo as normas vigentes do ambiente literário conservador. Destarte, o romance de aventura, um subgênero segundo a crítica literária do período, passaria por meio da tradução de um sistema marginal para o sistema central da literatura infanto-juvenil embrionária, tornando-se, então, parte do cânone literário infanto-juvenil, evidenciando o caráter dinâmico do polissistema literário.

Vale ressaltar que, ainda no âmbito da sua teoria, Even-Zohar avalia que a literatura considerada "menor" apresenta uma correlação com a literatura canônica devido ao aspecto dinâmico e heterogêneo dos sistemas. Assim, faz-se necessário levar em conta todos os tipos de obra literária, rejeitando a priori julgamentos de valor como critério para a seleção do objeto de estudo. Para Even-Zohar:

Por "canonizados" entendem-se aquelas normas e aquelas obras literárias (isto é, modelos e textos) que são aceitos como legítimos pelos círculos dominantes de uma cultura e cujos produtos conspícuos são preservados pela comunidade para tornar-se parte da herança histórica. Por outro lado, "não canonizados" significam aquelas normas e textos que são rejeitados por esses círculos como ilegítimos e cujos produtos, frequentemente, são esquecidos pela comunidade ao longo do tempo (a menos que eles mudem de status). Canonicidade não é, então, aspecto

\footnotetext{
${ }^{58}$ It is clear that the very principles of selecting the works to be translated are determined by the situation governing the (home) polysystem: the texts are chosen according their compatibility with the new approaches and the supposedly innovatory role they may assume within the target literature.

${ }^{59}$ Por sistema literário entende-se a produção, publicação e a existência de um público leitor.
} 
inerente da atividade textual em nenhum nível: não é eufemismo para "boa" versus "má" literatura (EVEN-ZOHAR, 1990, p. 15) ${ }^{60}$.

Mesmo transcendendo a avaliação simplista de boa ou má literatura, a formação do cânone ainda decorre do juízo estético, da autoridade e das regras da Academia. O crítico literário Harold Bloom (1995, p.3) busca a definição de obra canônica nas características do próprio texto, ressaltando que o que faz um autor ou obra serem canônicos é "o inusitado": "Quando você lê uma obra canônica pela primeira vez você encontra um estranho, uma incomum surpresa, mais do que a realização de uma expectativa" ${ }^{61}$, além de suas qualidades estéticas, que serão estabelecidas a posteriori. Indo na mesma linha Leyla Perrone-Moisés (2009, p. 16) concorda com Bloom e vai mais além: "Não se julga a partir de critérios, mas, ao julgar, criam-se critérios. Na leitura como na escrita, o julgamento é uma questão de invenção". As escolhas feitas por um grupo dominante, pelas instituições, irão conferir a sobrevivência da obra, que quebra paradigmas e estabelece o novo.

Todorov (1970, p. 94), assim como Bloom, considera a originalidade como característica canônica e afirma que "a grande obra cria, de certo modo, um novo gênero, e ao mesmo tempo transgride as regras até então aceitas". Se por um lado, quanto mais criativa e inovadora é uma obra, mais ela se desprende das normas, causando maior estranhamento, por outro, a inconformidade entre a obra e o gênero não existe na literatura de entretenimento. No caso da obra de literatura ligeira, que segue fórmulas pré-estabelecidas, elas se tornam mais passível de classificação e de exclusão do cânone: "A obra-prima habitual não entra em nenhum gênero senão no seu próprio; mas a obra-prima da literatura de massa é precisamente o livro que melhor se inscreve no seu gênero" (Idem, p. 95).

Apesar da análise positiva de Todorov, a expressão "literatura de massa" reflete a postura elitista que desvaloriza esse tipo de manifestação literária. A polarização das "literaturas" acha-se imbricada na ideologia, conforme observa Morin (1967, p. 19):

\footnotetext{
${ }^{60}$ By "canonized" one means those literary norms and works (i.e., both models and texts) which are accepted as legitimate by the dominant circles within a culture and whose conspicuous products are preserved by the community to become part of its historical heritage. On the other hand, "non-canonized" means those norms and texts which are rejected by these circles as illegitimate and whose products are often forgotten in the long run by the community (unless they change their status). Canonicity is thus no inherent feature of textual activities on any level: it is no euphemism for "good" versus "bad" literature.

${ }^{61}$ When you read a canonical work for a first time you encounter a stranger, an uncanny startlement rather than a fulfillment of expectations.
} 
Os intelectuais atiram a cultura de massa nos infernos intraculturais. Uma atitude "Humanista" deplora a invasão dos subprodutos culturais da indústria moderna. Uma atitude de direita tende a considerá-lo como divertimento de ilotas, barbarismo plebeu. É a partir da vulgata marxista que se delineou uma crítica de "esquerda", que considera a cultura de massa como barbitúrico (o novo ópio do povo) ou mistificação deliberada (o capitalismo desvia as massas de seus verdadeiros problemas

Não importa se de direita ou esquerda, para os críticos as manifestações da cultura de massa são mercadoria sem valor, alienando o homem no seu lazer. O menosprezo por obras cujo objetivo é entreter parece ser corrente:

O leitor, diante da história que acompanha curioso, indaga: "e depois?", "e então?", interessado na sucessão de fatos, e não no modo como se encadeiam, nas causas determinantes ou na compreensão dos truques aplicados pelo ficcionista. Essas preocupações denotam um leitor dotado de especial inteligência e memória, ao passo que o desdobramento linear da história satisfaz o leitor destituído de maiores interesses e recursos intelectuais (MOISÉS, 1967, p. 264).

Ainda para Massaud Moisés, trata-se de um tipo de leitura cujo objetivo é entreter contando uma história: "é $o$ que acontece e não $o$ como acontece, que nos fascina, se buscamos na sucessão de episódios e situações um divertimento que, desviando-nos a atenção da existência banal nos faculta a sensação de euforia e apaziguamento" (Idem, p. 170). A ênfase é posta nos acontecimentos e favorece a fantasia em detrimento da realidade.

Se o discurso literário tende a se caracterizar por sua complexidade e originalidade, no romance de aventura ele se aproxima do discurso "comum", de mais fácil entendimento. Além disso, o caráter lúdico desse tipo de narrativa atrai não somente o público menos letrado, mas também o público mais jovem, cumprindo uma função iniciática importante na formação leitores mais exigentes. Quanto mais popular a obra mais o romancista busca se adaptar às necessidades e às demandas do público, ao contrário do escritor de "literatura erudita" que cria partindo de sua concepção estética.

A denominação "romance de aventura" se deve ao fato de tais obras apresentarem uma "trama romanesca", ou seja, uma série de acontecimentos arranjados em sequência temporal. Aliado a esse aspecto, o "maniqueísmo que divide as personagens em boas e más, belas ou feias, poderosas ou fracas, etc. facilita à criança a compreensão de certos valores básicos na conduta humana ou convívio social" (COELHO, 1981, p. 33).

Como os romances de aventura são vistos como obras de pouco valor estético, "uma simples questão de estilo poderia, a princípio, parecer suficiente para a 
caracterização dos livros infantis" (MEIRELES, 1984, p. 29). Nos anos 1930, ao que tudo indica, a facilidade de leitura e o entretenimento parecem características suficientes para se considerar o romance de aventura uma obra destinada ao público jovem; entretanto, mais recentemente outras questões serão relevantes para a literatura infantojuvenil, como o nível de conhecimento do mundo.

\subsection{Texto e contexto na reflexão sobre tradução}

Tradicionalmente, na tradução literária existia o consenso de que a tradução era qualitativamente inferior ao original, pois seria, por natureza, um ato menos criativo do que o de escrever. Estando o tradutor sujeito a maiores restrições do que o autor, a tradução era considerada uma atividade ancilar, devendo o tradutor reproduzir "fielmente" o estilo do texto fonte. Sabe-se, contudo, que a busca de equivalências entre duas línguas é ilusória, pois parte do pressuposto da imutabilidade da língua, da estabilidade dos significados e da sinonímia perfeita.

Essa visão corrente viria ser contestada a partir dos anos 1990, quando os Estudos da Tradução sofreriam grande influência da teoria cultural e a cultura torna-se a unidade operacional da tradução, e não mais somente a palavra ou o texto, como preconizavam as correntes linguísticas e estruturalistas. Susan Bassnett e André Lefevere estão entre os primeiros a sugerir a adoção de uma perspectiva cultural na reflexão sobre a tradução. Esses autores denominaram essa mudança de "virada cultural na tradução" (cultural turn in translation) e advogaram que o estudo do processo tradutório, combinado com a práxis, pode oferecer uma maneira de entender a complexidade dessa atividade examinando todo processo de manipulação, que acontece também extratextualmente. Por exemplo: como um texto é selecionado para a tradução, qual o papel do editor, quem é o detentor político e financeiro do projeto e qual é a abrangência de sua influência, além da análise do texto em si. Para esses teóricos, não se devem abandonar os critérios de avaliação das estratégias utilizadas pelos tradutores e tampouco ignorar a recepção do texto na cultura alvo. (BASSNETT; LFEVERE, 1998: 123). Dessa maneira, a história cultural ampliou o escopo dos estudos da tradução, que passaram levar em conta outras questões contextuais e históricas. 
Em resumo, a "virada cultural" representou uma mudança de paradigma passando do caráter avaliativo, prescritivo e da análise puramente formalista do processo tradutório, para uma forma mais abrangente de considerá-lo, levando em conta questões de ideologia, contexto e história: "O objeto de estudo é redefinido; o que se estuda é o texto imerso na rede de signos da cultura fonte e da cultura alvo. Os estudos da tradução se tornam capazes tanto de utilizar a abordagem linguística como de transcendê-la" ${ }^{62}$ (BASSNETT; LEFEVERE, 1990, p. 12).

Consentaneamente a esse modo de considerar a tradução como sendo o estudo da interação cultural, e com o estabelecimento dos estudos da tradução como disciplina, surgem as discussões acerca do caráter criativo e autoral das traduções. Em decorrência dessa nova visão muitos teóricos se debruçam em pesquisas que buscam identificar a voz do tradutor e, através da análise de elementos linguísticos, procuram identificar seu estilo. Herança do romantismo, a noção de estilo esteve relacionada ao texto original, que seria original por ser o primeiro e também por ser único. Mona Baker explica que:

Isso se deve claramente ao fato de a tradução sempre ter sido tradicionalmente considerada uma atividade derivativa e não criativa. As implicações são que o tradutor não pode, de fato não deve ter um estilo próprio, a tarefa do tradutor é simplesmente de reproduzir o mais aproximadamente possível o estilo do original (Baker, 2000, p. 244) ${ }^{63}$.

Mas para Baker, admitir que a tarefa do tradutor seja a de reproduzir o "estilo" do original, ou seja, traduzir de maneira totalmente impessoal, seria como supor que se pode manusear um objeto sem deixar nele a impressão digital. A "impressão digital" (thumb-print) do tradutor, segundo Baker, transparece em vários momentos, desde a escolha do texto e das estratégias adotadas até aquilo que seria específico da linguagem do tradutor: "Entendo estilo como sendo um tipo de impressão digital que se revela em um gama de aspectos linguísticos - assim como não linguísticos. Nesse sentido a definição abrange a noção de 'voz' como entendida por Hermans, mas também muito mais" (Idem, p.245) ${ }^{64}$. Com essa afirmação Baker concorda com o conceito de "voz" na

\footnotetext{
${ }^{62}$ The object of study has been redefined; what is studied is the text embedded within its network of both source and target cultural signs and this way Translation Studies has been able to both utilize the linguistic approach and to move beyond it.

${ }^{63}$ This is clearly because translation has traditionally been viewed as a derivative rather than creative activity. The implication is that a translator cannot have, indeed should not have, a style of his or her own, the translator's task being simply to reproduce as closely as possible the style of the original.

${ }^{64}$ I understand style as a kind of thumb-print that is expressed in a range of linguistic - as well as nonlinguistic - features. As such, it covers the notion of 'voice' as defined by Hermans, but also much more.
} 
tradução como uma presença discursiva do tradutor, mas ressalta o aspecto restritivo da seguinte avaliação de Theo Hermans:

A voz pode estar mais ou menos explicitamente presente. Pode estar totalmente escondida atrás da do Narrador, tornando-se impossível de ser detectada no texto traduzido. Está mais efetivamente presente quando ultrapassa a superfície do texto falando por si, em seu nome, por exemplo, no paratexto de Nota do Tradutor, empregando uma primeira pessoa referencial identificada no sujeito falante. E entre um caso e outro há gamas e graus. (HERMANS, 1996, p. 27) ${ }^{65}$.

Mas, parece que para Hermans (1996, p. 26) a "invisibilidade" do tradutor também se deve ao fato de os leitores de ficção traduzida se esquecerem de que estão lendo tradução, pois são sugestionados por uma "ilusão de transparência" e "coincidência" entre discursos. Partindo dessa perspectiva, o tradutor imitaria, simularia, "falsificaria" a voz do narrador, tornando-se "inaudível". Ainda admitindo a possibilidade de um modelo que possa identificar a voz do tradutor, Hermans (1996, p. 43) defende que ele não poderia ser aplicado a todos os textos: "Somente em casos específicos é que a "outra" voz torna-se dissociada daquela que ela imita" ${ }^{66}$. Em seu artigo The translator's voice in translated narrative, Hermans exemplifica um desses casos por meio da análise das traduções de uma obra da literatura holandesa cujas características textuais levam os tradutores a adotarem estratégias que os deixam visíveis: "Com sua estrutura narrativa complexa, Max Havelaar oferece instâncias que são não somente de enraizamento cultural e autoreferência linguística, mas também de 'sobredeterminação contextual'" (Idem, p. 30) ${ }^{67}$.

Por "autoreferência" Hermans entende sendo um termo amplo que abarca várias instâncias no texto que podem levar à intraductibilidade: polissemia, jogos de palavras e trocadilhos. Com relação à "hiperdeterminação contextual" (as aspas são colocadas pelo autor para justificar a "falta de um termo melhor"), trata-se de uma expressão genérica que pode definir vários casos em que se "reduz de maneira drástica o espaço de manobra" do tradutor. No caso de sua análise, seriam as outras línguas que aparecem no

\footnotetext{
${ }^{65}$ The voice may be more or less overtly present. It may be entirely hidden behind that of the Narrator, rendering it impossible to detect in the translated text. It is more forcefully present when it breaks through the surface of the text speaking for itself, in its own name, for example in a paratextual Translator's Note employing an autoreferential first person identifying the speaking subject. And then there are shades and degrees in between.

${ }^{66}$ It is only in specific cases that the 'other voice becomes dissociated from the one it mimics.

${ }^{67}$ With its complex narrative structure Max Havelaar provides instances not only of cultural embedding and linguistic self-referentiality, but also of 'contextual overdetermination', all of them, to varying degrees, bringing the Translator's voice to the textual surface.
} 
texto dificultando a transposição quando se trata de tradução em uma delas. Isso acarreta, muitas vezes, omissão e/ou notas explicativas.

Apesar de interessante, a ideia de Baker de que se consiga, a partir de estudos de casos e por meio de corpora comparáveis, definir padrões característicos do tradutor, ou seja, definir seu estilo, a própria definição de estilo não é tarefa simples. Desde a clássica premissa de Buffon, "o estilo é o homem" ${ }^{68}$, as descrições podem ser mais ou menos limitantes. Segundo Pierre Guiraud (1970, p.17), estilo "é a maneira de escrever, a utilização pelo escritor dos meios de expressão para fins literários, distinguindo-se, portanto, da gramática, que define o sentido e a correção das formas". Nilce Sant'Anna Martins, por sua vez, assinala uma perspectiva mais abrangente:

Alguns só consideram o estilo na língua literária, outros o consideram nos diversos usos da língua; alguns relacionam o estilo ao autor, outro à obra, outros ainda ao leitor, que reage ao texto literário; alguns se concentram na forma da obra ou do enunciado, outros na totalidade do pensamento (SANT'ANNA MARTINS, 2000, p. 2).

É certo que as características individuais se manifestam nas escolhas do léxico com sua carga afetiva e sonora - nos desvios da norma e na modulação, mas os aspectos exógenos aos quais se encontram imbricados todos os tipos de criação literária também concorrem para o que se considera estilo. Na concepção de Monteiro Lobato (1955d, p. 37): "O estilo é a fisionomia da obra d'arte. Produto conjugado do homem, do meio e do momento, é pelo estilo que ela adquire caráter". Na reflexão de Lobato essa "fisionomia inconfundível" resulta em maior ou menor escala conforme a obra: algumas são mais suscetíveis ao "temperamento emotivo do artista" como a poesia e a pintura; outras manifestações estarão mais sujeitas às influências do meio.

O pensamento de Lobato vai ao encontro do de Mikhail Bakhtin. Dentre os conceitos da sua teoria abrangente, que tem merecido atenção por parte de diferentes áreas de conhecimento, a ideia de estilo descarta o caráter individual e particular, pois, partindo da reflexão de linguagem como sendo social, histórica e cultural, vai examinálo em seu aspecto dialógico, conforme observa Beth Brait:

Focalizado sob dimensão bastante especial, diferenciada, coerente com a "teoria dialógica" como um todo, estilo se apresenta como um dos conceitos centrais para se perceber, a contrapelo, o que significa, no conjunto das reflexões bakhtinianas, dialogismo, ou seja, esse elemento constitutivo da linguagem, esse princípio que

\footnotetext{
${ }^{68}$ Le style est l'homme même. Do discurso de George-Louis Leclerc, Comte de Buffon, na Academia Francesa em 25/08/1753.
} 
rege a produção e a compreensão dos sentidos, essa fronteira em que eu/outro se interdefinem, se interpretam, sem se fundirem ou se confundirem (BRAIT, 2005, p. 80).

Dessa maneira, o conceito de estilo, anteriormente pertencente ao campo exclusivo da linguística, passa para o âmbito do discurso e vai da esfera individual para a coletiva, uma vez que envolve, ainda segundo o pensamento de Bakhtin, "uma pessoa e mais seu grupo social" ${ }^{69}$, todos se relacionando em um momento histórico. Trazendo o pensamento dialógico para a tradução literária, a análise do estilo de uma obra deve ser considerada levando-se em conta dois momentos de produção, envolvendo duas "pessoas" (autor e tradutor) e dois "grupos sociais" (leitores do original e leitores da tradução), imersos em dois cenários históricos - distintos tanto espacial como temporalmente - e regidos por línguas diferentes, tendo como ponto em comum o gênero literário e o veículo material: o livro. Assim, mais de uma voz reverberaria no texto traduzido, sendo algumas mais audíveis que outras, dependendo do grau de influência dos fatores extratextuais, além dos linguísticos.

Este trabalho se baseia na ideia de Bakhtin sobre estilo e se alinha com a teoria de Gideon Toury, para quem a dimensão sociocultural da tradução literária também está presente. A partir da problematização de Even-Zohar sobre a maneira como a tradução de literatura se comporta no sistema literário receptor, Toury parte do pressuposto de que a tradução é um fato da cultura receptora e os tradutores operam em favor dela. Por ser a tradução por natureza um processo de tomada de decisão, o tradutor sempre tem mais de uma opção a sua disposição, mas essas opções não se restringem aos limites impostos pela língua alvo e não estão disponíveis de maneira equânime, "antes tendem ser ordenadas hierarquicamente" 70 no contexto da "constelação literário-cultural alvo" 71 (TOURY, 1995, p. 163). A preocupação desse teórico é prospectiva ao considerar a tradução como um produto no ambiente literário anfitrião: "As traduções são fatos das culturas receptoras; às vezes fatos de um status especial, ocasionalmente mesmo constituindo (sub)sistemas autônomos identificados, mas da cultura alvo em qualquer caso" $^{72}$ (TOURY, 1995, p. 29).

Considerando as traduções como "fatos culturais", Gideon Toury observa que essa atividade está sujeita às normas que regem a sociedade. Estas seriam o que a

\footnotetext{
${ }^{69}$ Apud Beth BRAIT, p. 83.

${ }^{70}$ Rather, they tend to be hierarchically ordered.

${ }^{71}$ Target literary-cultural constellation.

72 Translations are facts of target cultures; on occasion facts of a special status, sometimes even constituting identifiable (sub)systems of their own, but of the target culture in any event.
} 
sociologia considera como "a tradução de ideais ou valores gerais compartilhados por uma comunidade - quanto ao que é certo e o que é errado, adequado ou inadequado em instruções de desempenho apropriadas para, e aplicáveis a, situações particulares" (TOURY, 2003, p. 199) ${ }^{73}$. As "instruções de desempenho" no âmbito da sociologia e psicologia social especificam o que é proibido, permitido e tolerável no comportamento e servem de critério para a avaliação do indivíduo dentro de uma comunidade. A fuga às imposições das regras socioculturais gera idiossincrasias.

Mesmo admitindo as restrições impostas pelas línguas e as idiossincrasias dos tradutores como elementos que influenciam as estratégias de tradução, Toury (2003, p. 199) considera que esses aspectos também são regidos por fatores socioculturais, em maior ou menor grau: "As próprias normas formam um continuum gradativo ao longo de uma escala: algumas são mais fortes, portanto, assemelham-se mais a regras, e outras mais fracas, portanto, são quase idiossincráticas" ${ }^{74}$. Consequentemente, as normas atuam em todos os estágios do processo tradutório, inclusive no comportamento do tradutor, tornando-o apto a cumprir "um papel social", ou seja, "desempenhar uma função designada por uma comunidade - para a atividade, para seus praticantes e/ou para suas produções - de maneira que seja considerada apropriada de acordo com suas próprias condições e referências" (Idem, p. 198) ${ }^{75}$. Em um amplo espaço intermediário (vast middle-ground) que separa as regras das idiossincrasias atuam vários agentes envolvidos na tradução além dos próprios tradutores - agentes literários, editores, ilustradores, resenhistas - envolvidos na realidade cultural e comprometidos com a produção, seleção e divulgação das obras.

Assim, as normas são um fator-chave em qualquer estudo das atividades sociais, sendo elas eficazes e essenciais. Mesmo atentando para o fato de que não se podem subestimar as dificuldades advindas de uma tentativa de explicitar as normas tradutórias dada a sua multiplicidade, Toury elenca três tipos de normas: inicial, preliminar e operacional. A norma inicial se refere às exigências de duas possibilidades diferentes. O tradutor pode se sujeitar tanto ao texto original, com as normas sob as quais ele foi realizado, estabelecendo uma "adequação", ou às normas ativas na cultura alvo,

\footnotetext{
${ }^{73}$ The translation of general values or ideas shared by a community - as to what is right or wrong, adequate and inadequate - into performance instructions appropriate for and applicable to particular situations.

${ }^{74}$ The norms themselves form a graded continuum along the scale: some are stronger, and hence more rule-like, other are weaker, and hence more idiosyncratic.

${ }^{75}$ To fulfill a function allotted by a community - to the activity, its practitioners and/or their products - in a way which is deemed appropriate in its own term and reference.
} 
determinando uma "aceitação" 76 da obra traduzida. O conceito de "adequação", juntamente com o de "equivalência", conforme relatado no capítulo 2, era o paradigma da tradução nas primeiras décadas do século 20.

As normas preliminares dizem respeito à política tradutória e aos fatores que governam a existência e natureza da tradução, além daqueles relacionados com a sua recepção. Nesse âmbito questiona-se a escolha dos tipos de textos a serem traduzidos e se as traduções serão diretamente da língua original ou intermediadas por outra tradução. Quanto a este último caso, a correspondência de Manuel Bandeira revela que muitas vezes a editora forneceu traduções em outras línguas, na época mais conhecidas, para "ajudar" no trabalho do tradutor.

Como as normas operam em todos os níveis da tradução, aquelas que direcionam as decisões tomadas durante o ato tradutório Toury denomina de operacionais, subdividindo-as em matriciais e linguístico-textuais. As normas matriciais "governam a própria existência do material da língua-alvo destinado como substituto para o material correspondente da língua-fonte (e assim o grau de completude da tradução), sua localização no texto (ou a forma de distribuição efetiva), assim como a segmentação textual" 77 (Idem p. 202). Destarte, as omissões, acréscimos, manipulação da segmentação do texto serão determinadas por essas normas.

As normas linguístico-textuais, por sua vez, governam a seleção do material linguístico, no nível semântico e sintático e, talvez sejam as mais evidentes, pois, conforme atenta Toury (1995, p. 209), o aspecto distintivo da língua está no léxico, uma vez que os itens lexicais são os mais fáceis de serem discernidas. Entretanto, Toury (Idem, p. 206) adverte contra um estudo que aborde somente um aspecto: "Precisamente porque a relação entre Estudos da Tradução e Estudos Lexicais parecem oferecer tantas possibilidades de cooperação, é bastante desencorajador descobrir que eles são normalmente abordados de uma perspectiva somente" ${ }^{78}$.

Mesmo com o concurso dessas duas áreas na pesquisa em tradução, Toury hierarquiza as normas declarando terem as normas preliminares precedência lógica e

\footnotetext{
${ }^{76}$ Thus, whereas adherence to source norms determines a translation's adequacy as compared to the source text, subscription to norms originating in the target culture determines its acceptability.

${ }_{77}$ So-called matricial norms may govern the very existence of target-language material intended as a substitute for the corresponding source-language material (and hence the degree of fullness of translation), its location in the text (or the form of actual distribution), as well as the textual

${ }^{78}$ Precisely because the relations between Translation Studies and Lexical Studies seem to offer so many possibilities of cooperation, it is quite discouraging to find out that they have normally been approached from one perspective only.
} 
cronológica sobre as operacionais, estabelecendo a influência do contexto e dos agentes envolvidos sobre as especificidades linguísticas dos textos fonte e alvo. A partir do papel que as normas desempenham na tradução, a análise da literatura traduzida não deve ser somente um cotejo entre texto fonte e texto alvo buscando diferenças e/ou equivalências de ordem linguística, mas também levar em conta os fatores condicionantes fora do texto, uma vez que o "aparato cognitivo" do tradutor também é influenciado pelo contexto.

Maria Tymoczko estabelece um paralelo com os postulados de Toury ao propor uma análise de tradução dentro do ambiente literário da cultura de chegada, observando que a associação de uma abordagem cultural com a abordagem linguística torna-se um campo fértil para a pesquisa, que abrirá várias perspectivas no que concerne à língua, ao texto e a cultura. Para essa autora o estudo é mais significativo quando "mostra uma convergência - trabalhando em direção ao macroscópico a partir do microscópico, ou vice versa, para que os dados do nível macroscópico sejam complementados e confirmados pelos dados do nível microscópico" ${ }^{79}$ (TYMOCZKO, 2002, p. 17).

Quando o estudo parte do nível macroscópico, a cultura torna-se um elemento primordial. Como metodologia a autora sugere a comparação de duas ou mais traduções de um mesmo texto ou de textos similares, pois pode ser mais reveladora do que somente o cotejo do original com um texto traduzido. A análise comparativa faz com que as normas, definidas por Toury, sejam mais perceptíveis. Após a definição do corpus, Tymoczko julga necessário estabelecer um limite no objeto de estudo:

Porque é impossível (e normalmente irrelevante) estudar exaustivamente o texto inteiro de uma ou mais traduções, a segunda tarefa seria de escolher passagens perspícuas que servirão para testar a hipótese ou hipóteses. Uma vez identificadas as passagens, a tarefa é de buscar anomalias linguísticas e desvios que reflitam as questões culturais que estão sendo investigadas ${ }^{80}$ (Idem p. 18).

As abordagens descritas neste capítulo não são excludentes e podem se complementar, pois, em última análise, partem da premissa de que a tradução é uma atividade orientada por normas que não podem ser desvinculadas do contexto maior das culturas envolvidas no processo. A partir dessa perspectiva, a tradução de Tarzan como

\footnotetext{
${ }^{79}$ [...] shows a convergence - working toward the macroscopic from the direction of the microscopic, or vice versa, so that one's data from the macroscopic level are complemented and confirmed by data from the microscopic level.

${ }^{80}$ In turn, because it is impossible (and usually irrelevant) to study exhaustively the full text of one or more translations, the second task will be to pick perspicuous passages that will serve to test one's hypothesis or hypotheses. Once such texts and passages are identified, the task is to look for linguistic anomalies and perturbations reflecting the cultural issues that are being investigated
} 
fonte primária para o estudo do impacto dos fatores exógenos e do gênero na presença discursiva do tradutor levará ao cotejo do texto alvo com o texto fonte como ferramenta de análise. Contudo, a pesquisa requer abrangência mais ampla envolvendo aspectos exógenos à obra. Esse tipo de estudo é validado pelas considerações elencadas por Lieven D'Hulst (2001, p. 22):

- A história abre os olhos;

- A história proporciona flexibilidade intelectual para adaptar-se a outros pontos de vista;

- A história evita cegar-se com uma única teoria;

- A história é talvez a única maneira para entender a estrutura de nossa disciplina;

- A história contribui para o desenvolvimento de uma "cultura de tradução";

- A história pode ajudar a encontrar técnicas de resolução de problemas.

Assim como Lieven D’Hulst, Jenny Williams e Andrew Chesterman (2002, p. 16) ao destacarem as seguintes questões como centrais ao estudo da tradução: "Quem? O que? Por que? Como?" abrangem aspectos que ultrapassam os limites do texto. Para o presente trabalho a importância da abordagem histórica reside nas hipóteses de que as condições de recepção e produção e o momento histórico são fatores decisivos no resultado da tradução e de que o gênero literário impõe condicionantes que tendem a limitar o caráter autoral e criativo da atividade.

\subsection{Critérios para a análise}

Com relação a este estudo, que parte do "nível macroscópico" (TYMOCZKO, 2002, p. 17), o primeiro passo metodológico foi pesquisar o momento histórico e o papel desempenhado pela tradução no período estudado. Nesse panorama verificou-se o grande número de traduções de obras de "menor valor literário", que por terem sido realizadas por "grandes nomes das letras" careciam de estudo. A investigação revelou a importante atuação da Companhia Editora Nacional na divulgação da literatura de entretenimento. A partir dessa constatação, e em consonância com o postulado da teoria do polissistema de que sem o estímulo de uma "subcultura" forte, o cânone se "petrifica" (EVEN-ZOHAR, 1990, p. 17), fez-se um levantamento dos títulos e definiuse o corpus elegendo três obras da série Tarzan: Tarzan, o terrível, tradução de 
Monteiro Lobato, Tarzan, o rei da jângal, tradução de Godofredo Rangel, e $O$ tesouro de Tarzan, tradução de Manuel Bandeira. As obras traduzidas, adquiridas em sebos, foram digitalizadas e transformadas em arquivo "ponto doc". Os textos fonte, por serem de domínio público, já estavam em formato eletrônico no domínio do Projeto Guttenberg. Os exemplares em português utilizados na análise são da primeira edição, à exceção de $O$ tesouro de Tarzan, de 1949 (a primeira edição é de 1934).

A escolha dos elementos para análise fundamentou-se nos corpora comparáveis de Baker, que preconiza, primeiramente, identificar a presença de alguns aspectos em comum entre eles. Por isso, foram, então, selecionadas três obras do mesmo autor (Edgar Rice Burroughs), consequentemente, da mesma língua fonte (inglês), para a mesma língua alvo (português) e traduzidas durante o mesmo período (a década de 1930), por três tradutores diferentes, contemporâneos e detentores do mesmo capital cultural. Contudo, diferentemente de trabalhos como o de Baker, os procedimentos metodológicos adotados para a análise, afora o alinhamento dos textos, não contemplam a utilização ferramentas eletrônicas de rastreamento de padrões linguísticos, como o software Wordsmith Tools $\odot$, pois a metodologia aqui sugerida transcende a análise textual e se alinha com Toury (1995, p. 36-39) que oferece um estudo descritivo da tradução, primeiramente, situando o texto no sistema cultural em que está imerso e, a seguir, cotejando o texto fonte e o texto alvo formando "pares" (coupled pairs) que apontem desvios e deslocamentos. Assim sendo, a análise não dispensará a consulta ao original, pois muitas características reveladoras da atitude do tradutor podem ser identificadas no cotejo, como, por exemplo, as omissões e os acréscimos. A análise contrastiva também pode revelar não apenas a existência de similaridades, mas também suas diferenças.

Essa proposta busca responder as seguintes questões: Como se articula o caráter individual do tradutor com o contexto em que está inserido e até que ponto o contexto imprime sua marca na tradução? Qual a melhor maneira de identificar os elementos estilísticos do tradutor e separá-los daqueles que são do autor do texto fonte? Igualmente confirmando a existência da "voz" do tradutor, Baker (2000, p. 248) formula as perguntas de maneira mais detalhada, alargando a moldura metodológica:

a) Seria a preferência do tradutor por estruturas linguísticas específicas independente do estilo do autor? 
b) Seriam essas escolhas do tradutor independentes da língua de origem e possivelmente das normas ou poéticas de um dado socioleto?

c) Se a resposta for sim para ambos os casos, seria possível explicar essas preferências em termos do posicionamento social, cultural ou ideológico do tradutor? ${ }^{81}$

Dessa maneira, a abordagem descritivista amplia as possibilidades do modelo de análise para especular se a existência de padrões nos textos traduzidos pode identificar traços de estilo do tradutor e, portanto, evidenciar sua presença discursiva. Além disso, se as escolhas e estratégias adotadas podem revelar atitudes do tradutor com relação ao texto, ao público leitor e/ou indicar o seu grau de competência linguística.

No entanto, uma vez que a análise ocorre através de um olhar em retrospectiva, uma das dificuldades é distinguir o que seria idiossincrático do tradutor daquilo que seria de uso corrente da época. A fim de rastrear essa diferença as ferramentas utilizadas foram, além do Diccionario Contemporaneo da Lingua Portugueza, de 1925, dois recursos digitais: o Corpus do Português ${ }^{82}$ permite comparar em 57.000 textos do século XIV ao XX palavras, frases, expressões, partes do discurso e palavras relacionadas (collocates), além de permitir comparar a frequência e distribuição das palavras e construções gramaticais nos textos; o Compara ${ }^{83}$ é "um corpus paralelo bidirecional de português e inglês. Ou seja, é uma espécie de base de dados com textos originais nestas duas línguas e as suas respectivas traduções, ligado frase a frase".

Partindo da premissa de que a tradução é uma atividade orientada por normas culturais e históricas, o corpus será avaliado não só nos seus aspectos textuais, como nos paratextuais. Os paratextos tornam-se importantes na análise das traduções de Tarzan, pois determinam um lugar, uma época, a recepção e, ainda sua função. Gérard Genette (2009, p. 9) esclarece que "a obra literária raramente se apresenta em estado nu, sem o reforço e o acompanhamento de certo número de produções verbais ou não", por conseguinte, tudo que se refere à materialização da obra terá influência sobre sua recepção e consumo. Ora, se os paratextos formam um aparato que completa a obra literária conferindo-lhe um modo de ser recebida e uma interpretação compatíveis com

\footnotetext{
${ }^{81}$ (a) Is a translator's preference for specific linguistic options independent of the style of the original author?; (b) Is it independent of general preferences of the source language, and possibly the norms or poetics of a given sociolect?; (c) If the answer is yes in both cases, is it possible to explain those preferences in terms of the social, cultural or ideological positioning of the individual translator?

${ }^{82} \mathrm{http}: / / \mathrm{www}$.corpusdoportugues.org/

${ }^{83}$ http://193.136.2.104/COMPARA/
} 
o propósito do autor, então esses elementos serão também significativos para a análise de tradução. Vale observar que cada paratexto traz em si razões distintas:

O texto traduzido em si estaria "condicionado" principalmente por questões de linguagem, os paratextos editoriais expressam mais fortemente as restrições de patronagem, enquanto outros paratextos, dentro da publicação, são influenciados predominantemente por fatores dos próprios profissionais e poéticas (NOWINSKA, 2012, p. 68).

Os paratextos podem estar "dentro" e "fora" do livro. Genette (2009, p. 12) estabelece que os que se encontram "em torno do texto, no espaço do mesmo volume, como o título ou o prefácio, e, às vezes, inserido nos interstícios do texto, como os títulos de capítulos ou certas notas" são os peritextos. Mas, para garantir "sua presença no mundo", outros elementos que não se encontram materializados no livro também devem ser considerados: resenhas, entrevistas, cartas, enfim "todas as mensagens que se situam, pelo menos na origem, na parte externa do livro" e que Genette chama de epitexto. Essas duas categorias irão, ainda segundo Genette (2009, p. 12), "dividir entre si, exaustivamente e sem descanso, o campo espacial do paratexto; dito de outra forma, para os amantes de fórmulas, paratexto $=$ peritexto + epitexto $"$.

A existência de paratextos de determinada obra é de grande valia para um estudo que transcenda a análise textual. No entanto, conforme observa Genette (2009, p. 11), a presença desses elementos não é "obrigatória", manifestando, portanto, um "caráter irregular", mesmo dentro de um mesmo sistema literário, pois é dependente da política editorial, do mercado, do prestígio da obra e do tradutor, se for o caso. Partindo do princípio de Genette (Idem, p. 14) de que "todo contexto forma paratexto", o trabalho levará em conta tudo aquilo que cerca e prolonga o texto, "exatamente para apresentálo, no sentido habitual do verbo, mas também em seu sentido mais forte: para torná-lo presente, para garantir sua presença no mundo, sua "recepção" e consumo, sob a forma, pelo menos de hoje, de um livro" (p. 9).

A importância da atenção aos elementos paratextuais neste estudo converge com a posição de Else Vieira (1992, p. 146): "A minha unidade operacional é a macroestrutura, ou seja, a cultura na sua dimensão histórica e política, e são os elementos paratextuais que, como veremos, fornecem os referenciais contextuais". Nos paratextos se manifestam o poder de várias instâncias, desde as demandas editoriais e/ou do autor, até a escolha do ilustrador e do tradutor. Tudo aquilo que se refere a um texto publicado, 
mas que não se encontra materializado no objeto livro é epitexto, consequentemente a diferença entre peritexto e epitexto é, em princípio, puramente espacial.

Genette divide o epitexto em público (entrevista, resenhas, material promocional) e privado (correspondências, diários íntimos); entretanto, as categorias não são estanques, pois o privado pode tornar-se público pela publicação, como as cartas que são reunidas em A barca de Gleyre. De início seriam epitextos privados, mas com a publicação delas em coletânea de correspondência, tornaram-se epitextos públicos. Pelo exposto os epitextos são aqui divididos em epitextos editoriais e epitextos acidentais. Destes últimos, com referência a Tarzan, o que se apurou foram os excertos das cartas de Bandeira e Lobato, a menção no conto de Caio Fernando Abreu, o samba de Noel e o depoimento de Ruy Castro, mencionados no capítulo 4.

Resenhas, comentários em cartas, fichas editoriais e outras informações foram buscadas nos arquivos da Companhia Editora Nacional. Uma parte do arquivo ainda se encontra na sede da editora e a outra, no Centro de Memória e pesquisa Histórica do Departamento de História da Universidade Federal de São Paulo, campus Guarulhos. Segundo a pesquisadora Maria Rita Toledo ${ }^{84}$ o primeiro guarda o chamado arquivo morto dos selos IBEP e Nacional e o último, o arquivo vivo, contém documentos somente da Nacional.

Infelizmente, apesar de inúmeros contatos por telefone e por correio eletrônico, não foi possível consultar o arquivo da editora. A informação obtida sobre ele é de que apresenta estado de precariedade tanto no que se refere ao ao armazenamento e classificação quanto ao conteúdo da documentação, o que é lamentável dada a importância da editora na formação do público leitor, na divulgação da literatura e de autores e no desenvolvimento da indústria livreira.

O arquivo vivo, por sua vez, está em fase de organização no campus de Guarulhos da UNIFESP. O acervo é acessível à pesquisa e conta-se com o auxílio de estagiários, porém ainda precisam ser catalogados de maneira a facilitar a consulta. Dentre os dossiês consultados, contendo contratos, correspondência entre editoras e autores, etc, nada foi encontrado referente ao período deste estudo. Os poucos epitextos

\footnotetext{
84 "A indústria do livro, a materialidade do impresso e o campo educacional: reflexões sobre a organização do acervo histórico da Companhia Editora Nacional". http://sbhe.org.br/novo/congressos/cbhe3/Documentos/Individ/Eixo1/019.pdf
} 
localizados relacionam-se com a recepção da obra de Burroughs e atestam sua sobrevida.

Os peritextos (conforme definição de Genette) serão analisados do exterior para o interior, ou seja, iniciando-se pela capa, seguindo para a orelha, folha de rosto, contracapa, etc. Um peritexto comum do livro é o discurso a propósito do texto e que pode antecedê-lo (prefácio) ou sucedê-lo (posfácio). Nos livros traduzidos o prefácio do tradutor é o elo que liga o texto fonte com o texto alvo "corporificando a ambiguidade e a tensão da tradução como espaço da referência dividida", conforme sustenta Else Vieira (1992, p. 158). Se o tradutor toma da palavra, ele ganha em exponibilidade e seu discurso antecede o do autor "criando interpretantes que estruturarão a futura recepção e a leitura da obra" (Idem, p. 161).

Seguindo as convenções editoriais, o livro traz na sua capa o nome do autor, o título e a editora. No caso do livro traduzido o nome do tradutor pode ou não figurar aí. As informações, visuais e verbais, contidas na capa e folha de rosto fornecem indícios do gênero, do lugar e da época e irão predispor o leitor com relação ao texto. A capa, além de proteger o miolo, um conjunto de folhas, anuncia um contexto. Alan Powers (2008, p. 7) observa que "a capa, sem dúvida, cumpre um papel no processo de envolvimento físico com o livro, pois, embora não se possa olhá-la enquanto se lê, ela o define como objeto a ser apanhado, deixado de lado e talvez conservado ao longo do tempo".

A ilustração da capa cria uma expectativa no leitor com relação ao texto e a primeira ideia é a de que se deva reproduzir algum conteúdo textual. Perry Nodelman (1988, p. 50) avalia que a capa seria uma surpresa instigante à imaginação e que teria sido escolhida para transmitir a essência da história e dessa maneira estabelecer a expectativa apropriada sobre ela. Destarte, a ilustração da capa se aproxima da tradução pela sua natureza interpretativa e metonímica, invocando o conceito de Maria Tymoczko (1999, p. 55) de que "a tradução é uma forma de representação cujas partes ou aspectos do texto fonte aparentam o todo".

Com relação ao livro traduzido, Else Vieira (1992, p. 148) ressalta que os elementos peritextuais (capa, contracapa, prefácio etc.) "são como Janus, bifaciais. Há a face que se fecha para o que a antecede e a face que se abre para o que a sucede e, interligando as duas faces, a interface, um entre-lugar, o seu limiar". Realmente, as informações contidas nesses peritextos, por menores que sejam, podem revelar os 
fatores a que está condicionada a publicação da obra e também muito de sua recepção. Essa materialidade transforma o texto em objeto que pode ser percebido pelo leitor tanto como tradução quanto como original.

Portanto, o ponto de partida do próximo capítulo será a análise dos paratextos, pois trata-se de "um recorte que lança as bases do desenvolvimento posterior da análise do texto traduzido em sua articulação com o(s) contexto(s)" (Idem, p. 146). Entretanto, o fato de se levar em conta os paratextos não significa que a análise textual seja relegada a um segundo plano e alguns elementos podem fornecer parâmetros para ela.

Além desses aspectos a serem considerados, o texto per se apresenta algumas características comuns que podem contribuir para o cotejo entre traduções, elencadas a seguir:

1) A ambientação:

Nos livros de Tarzan, o espaço gera um campo semântico específico da selva e de palavras que designam formações geológicas, acidentes geográficos, eventos da natureza, que não encontram equivalência, ou a encontram em parte, no português. Nesse cenário, termos que se relacionam conceitualmente são organizados de forma que um termo mais geral pode substituir o mais específico. Entretanto, ao adotar-se um hiperônimo para traduzir um hipônimo o significado será expresso somente em parte. A palavra genérica de um campo semântico é parte do significado de seus hipônimos, mas não vice-versa. Decorrente dessa "deficiência", que ocorre em todas as línguas, muitas dessas palavras acabam por entrar na outra língua em sua forma original, como estrangeirismos, como handicap.

2) A descrição da ação:

A língua inglesa possui verbos que transmitem de maneira precisa a direção do movimento, com ou sem preposição ou advérbio. A grande variedade de verbos de movimento da língua inglesa favorece a descrição das cenas de ação, desde lutas entre homens até ataques de feras, descrevendo-a numa só palavra a natureza, a direção do deslocamento e, por vezes subentendendo um som, que além de significar o movimento de queda, reproduz um som surdo provocado por ela, como thud, por exemplo. Para reproduzir todo o material semântico em português, faz-se necessário recorrer a outros recursos como acréscimos ou paráfrases para designar a maneira exata como se dá o movimento.Na maioria das vezes, a falta de equivalência no português desses verbos demanda diferentes estratégias para reproduzir a cena e transmitir a mesma sensação. 
3) Além do item lexical:

Nesta seção pretende-se fazer um levantamento das particularidades nos textos alvos que possam insinuar as estratégias adotadas pelos tradutores e em que medida elas diferem entre os textos, apontando também para as possíveis razões dessas escolhas.

Se nas seções anteriores a discussão parte de aspectos do léxico existentes nas três narrativas, discutindo problemas advindos da falta de equivalência e da questão da sinonímia, nesta serão analisadas cada tradução separadamente, buscando escolhas que marquem a presença do tradutor no texto.

Em uma obra como Tarzan, direcionada a um público menos letrado e jovem, espera-se uma linguagem mais próxima da fala "comum". Dentre os recursos usados na linguagem coloquial acham-se construções linguísticas de diferentes tipos: expressões idiomáticas, frases feitas, clichês, frases metafóricas, que podem apresentar um problema para a tradução, pois poucas vezes há correspondência na língua alvo, e quando há, é necessário que se conheça bem o seu uso na língua fonte para escolher aquele que melhor expresse a ideia, na cultura de chegada.

Essas formas de expressão são recursos da qual se serve cada cultura para dar ênfase, acentuar a ironia ou amenizar certos conceitos de maneira figurada. Paulo Henriques Britto assim avalia a tradução de obras como Tarzan:

Quando a tradução é destinada a leitores com menos sofisticação intelectual, ou a um público infanto-juvenil, o tradutor tenderá a lançar mão de estratégias domesticadoras, com o objetivo de não afastar o leitor, que talvez deixasse o livro de lado se encontrasse uma dificuldade excessiva na leitura (BRITTO, 2012, p. 64).

Por ser considerada de leitura fácil, pressupõe-se que o romance de aventura não ofereça muitos obstáculos à tradução. A análise contrastiva poderá revelar se o tradutor fez escolhas consistentes e se essas escolhas são baseadas no estilo do gênero, no estilo do autor ou, ainda, na representação que o tradutor tem do público receptor. 


\section{O HOMEM-MACACO DE GALHO EM GALHO}

[Tarzan] Père de toute l'Afrique, il la gouverne en despote éclairé, avec le mélange d'amour et de sévérité du pater familias ayant droit de vie et de mort sur ses enfant. Il n'en abuse pas, mais il détermine lui-même ce qu'il croit être leur bien.

Francis Lecassin

\subsection{Criador e criatura}

Tarzan, herói singular que transita pelo mundo "primitivo" e "civilizado", é fruto do espírito aventureiro de Edgar Rice Burroughs ${ }^{85}$, que nascido na urbana Chicago, passou boa parte da vida em lugares então inóspitos. Aos quinze anos, seus pais o mandaram para a fazenda dos irmãos mais velhos em Idaho para fugir de uma epidemia de gripe. Nas terras então inóspitas aprendeu a montar, a trabalhar com o gado e conviveu com foras-da-lei. Os pais, preocupados com o ambiente de leis frouxas e de contendas constantes, mandaram o jovem Edgar para a Academia Militar em Michigan.

Formado em 1875 e ansiando por ação, Burroughs alistou-se no exército. Sua habilidade de cavaleiro granjeou-lhe um posto no mesmo regimento do lendário General Custer ${ }^{86}$ (The Seventh United States Cavalry) baseado em Fort Grant, no território do Arizona. Nesse período Burroughs que almejava pegar índios apaches, limitava-se a cavar fossos e consertar a paliçada do forte. Durante um exame médico de rotina foi constatado um sopro no coração e assim encerrou-se a carreira militar de Burroughs em 1897.

\footnotetext{
${ }^{85} \mathrm{Cf}$. https://www.edgarriceburroughs.com/

${ }^{86}$ George Armstrong Custer (1839-1876), general americano massacrado com seu pelotão pelos índios Sioux em Montana.
} 
Burroughs volta para a vida selvagem da fazenda dos irmãos em Idaho por um breve período, mas termina por ocupar um posto na empresa de seu pai a American Battery Company. Com salário regular, decide se casar com sua amiga de infância, Emma Centenia Hubert, em 1900. Seguiu-se uma série de trabalhos como vendedor, contador, gerente de departamento da Sears, Roebuck \& Company e finalmente o emprego que iria despertar a vontade de escrever. Como vendedor em uma empresa atacadista de apontadores de lápis, uma das tarefas de Burroughs era verificar os anúncios da mercadoria em várias revistas, cuja maioria era de pulp fiction ${ }^{87}$ e de tanto ler as histórias de aventura nasceu-lhe uma ideia.

Os primeiros escritos de Burroughs consistem em histórias de fadas e poemas para suas duas crianças e seus sobrinhos. Em 1911, decide escrever uma novela completa, Dejah Thoris Martian Princess (Dejah Thoris uma princessa marciana), que de tão fantástica e exótica decide usar o pseudônimo jocoso de Normal Bean, receoso de que os editores o considerassem meio maluco. A revista All-Story pagou-lhe 400 dólares, soma considerável à época, e publicou-a em capítulos rebatizada de Under the Moons of Mars (Sob as luas de Marte). Ao ser lançado o último capítulo, Burroughs havia completado sua terceira história. A segunda intitulada The Outlaw of Torn $(\mathrm{O}$ proscrito de Torn), havia sido rejeitada e a terceira, Tarzan of the Apes, (Tarzan dos macacos) lhe renderia 700 dólares e lhe traria fama. Burroughs tornava-se um escritor profissional.

A saga de Tarzan se inicia em 1912 com a publicação dos primeiros capítulos de Tarzan dos macacos na revisa All Story. Em 1914 essa mesma história é lançada em livro e em 1918, o primeiro Tarzan é transposto para a tela do cinema mudo, o que ajudou a popularizar ainda mais o autor. Ao todo Burroughs escreveu 26 histórias de Tarzan e ainda deixou um manuscrito inacabado. Apesar de Tarzan ser o maior sucesso de Burroughs, sua imaginação produziu todo tipo de história fantástica: horror com The Monster Man; "western" com The War Chief; aventura na pré-história com The Eternal Savage e The Land that Time Forgot; e ficção científica com a série John Carter, um veterano confederado que é misteriosamente transportado para Marte.

Em 1919, graças ao grande sucesso de Tarzan, Burroughs adquire uma grande fazenda ao norte de Los Angeles e a denomina Tarzana. Posteriormente, divide e loteia a terra para um empreendimento residencial de pequenas chácaras. O loteamento era,

\footnotetext{
${ }^{87}$ Pulp fiction é um termo usado para descrever revistas com histórias de ficção fantástica para consumo de massa no início do século 20 . O nome deriva do papel barato de "polpa" usado na publicação.
} 
como muitas das comunidades planejadas na área de Los Angeles no período (década de 1920), exclusivo para a comunidade branca, com uma cláusula de segregação incluída na escritura. Burroughs fazia publicidade de seu empreendimento usando termos que evocavam o imperialismo britânico e a supremacia branca, segundo a página oficial da cidade na internet ${ }^{88}$.

Em 1929, ano do crack da bolsa de Nova York e do início do colapso econômico americano, o lançamento da história em formato de quadrinhos, com ilustrações de Harold Foster e baixo custo de produção tornam a história popular por tratar-se de fonte acessível de entretenimento. Nelly Novaes Coelho analisa o poder simbólico das histórias de Tarzan, importante nesse momento de adversidade da história americana:

Os livros sobre Tarzã mostram bem o que divulgação através da imagem pode fazer para transformar em best-seller uma obra literariamente medíocre. A verdade é que o seu motivo (o confronto entre o primitivismo e a civilização, com grande vantagem para as virtudes do primeiro, vinham de encontro a uma funda necessidade da época: recuperar a confiança no homem e em seu poder de vitória contra as forças adversas que o ameaçavam ou esmagavam (COELHO, 1981, p. 291).

Para o estudioso da cultura de massa, Francis Lecassin, em seu livro Tarzan ou le chevalier crispé (1971, p. 17), o homem do início do século 20 vive numa sociedade mecanicista industrializada que provoca o desejo de evasão e nada melhor do que um mito que evoca "os benefícios do oxigênio" e o compartilhamento de uma "odisseia silvestre". Mas, é exatamente o avanço tecnológico que irá propagar maciçamente suas histórias, traduzidas para 31 línguas.

Burroughs revelou seu espírito mercadológico e empresarial. Ao final do primeiro livro Tarzan of the apes, o autor coloca uma nota: "As demais aventuras de Tarzan, e as consequências de seu nobre ato de renúncia à própria identidade, serão contadas no próximo livro de Tarzan" (2014, p. 329), criando expectativa nos leitores à moda de folhetim.

O tradutor Thiago Lins, na apresentação da edição de 2014 de Tarzan, o filho das selvas, relata que em 1939, Edgar Rice Burroughs venceu um concurso que elegia o maior escritor norte-americano vivo promovido pelo jornal Saturday Evening Post segundo os seguintes quesitos: o número de leitores, o sucesso em estabelecer um personagem na consciência mundial e a possibilidade de ser lido pela posteridade.

\footnotetext{
${ }^{88}$ http://en.wikipedia.org/wiki/Tarzana,_Los_Angeles\#cite_note-Loewen2005-2 Acesso em 19/03/2014.
} 
O grande sucesso editorial da série Tarzan talvez se deva à capacidade de entreter um grande número de leitores, de diferentes idades e graus de escolaridades. Burroughs capitalizou esse fenômeno de cultura de massa de todas as maneiras: quadrinhos, filmes e uso de imagem em propaganda. O público queria Tarzan em qualquer embalagem que lhe fosse apresentada. Consta que ele tenha sido um dos primeiros escritores a se tornar uma empresa, o que levaria a vantagens fiscais com a redução de impostos e, além disso, assegurava a comercialização dos livros e artigos relacionados e o controle sobre a utilização publicitária da personagem. Dentre os produtos mais variados - bebidas, roupas, cartões postais - com a imagem e o nome do herói, a companhia petrolífera Signal Oil of California lança a "gasolina Tarzan" e promete aos consumidores rodar mais longe e mais rápido. O comercial reproduz a figura de Tarzan dos desenhos dos quadrinhos dando o famoso grito:

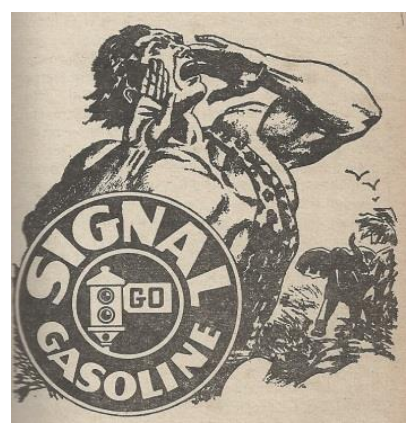

Figura 4: Cartaz de propaganda de gasolina ${ }^{89}$

Burroughs via no cinema um veículo de sucesso para suas histórias e se preocupou em adaptar seus livros. Em 1918, a empresa National Film Corporation Leva às telas os primeiros capítulos de Tarzan of the Apes. Além de Tarzan, Burroughs escreve dois ou três roteiros originais para filmes. Na era do cinema mudo foram realizados quatro filmes, mas o Tarzan mais famoso foi no cinema sonoro protagonizado pelo nadador Johnny Weissmuller que participou de doze filmes, sendo o primeiro de 1932. O musculoso Weissmuller representava um herói mais selvagem que o nobre inglês do livro e foi o responsável por criar sonoramente, o grito de vitória, que seria então reproduzido por todos os Tarzans subsequentes.

Não obstante o interesse de Burroughs pela sétima arte, Thiago Lins ${ }^{90}$ observa que as caracterizações cinematográficas que mostravam um Tarzan com menos intelecto

\footnotetext{
${ }^{89}$ In: Francis LACASSIN, p. 33.
} 
e mais músculos não agradaram a Burroughs. Comparando o personagem do livro com aqueles representados pelos atores de cinema, Ruy Castro ${ }^{91}$ assim considera o Tarzan idealizado por Burroughs:

Seu personagem é um herói adulto, sensível, apto a peripécias, mais rico em livro do que nos filmes a seu respeito. Não é primitivo como o Tarzan de Elmo Lincoln, burro como o de Johnny Weissmüller e, muito menos blasé como o de Lex Barker.

Um exemplo de "idiotização" da personagem é a fala primitiva "Me Tarzan you Jane", que se tornou um bordão mesmo sem nunca ter sido proferida pelo herói nas histórias de Burroughs, ilustrada nos quadrinhos abaixo:

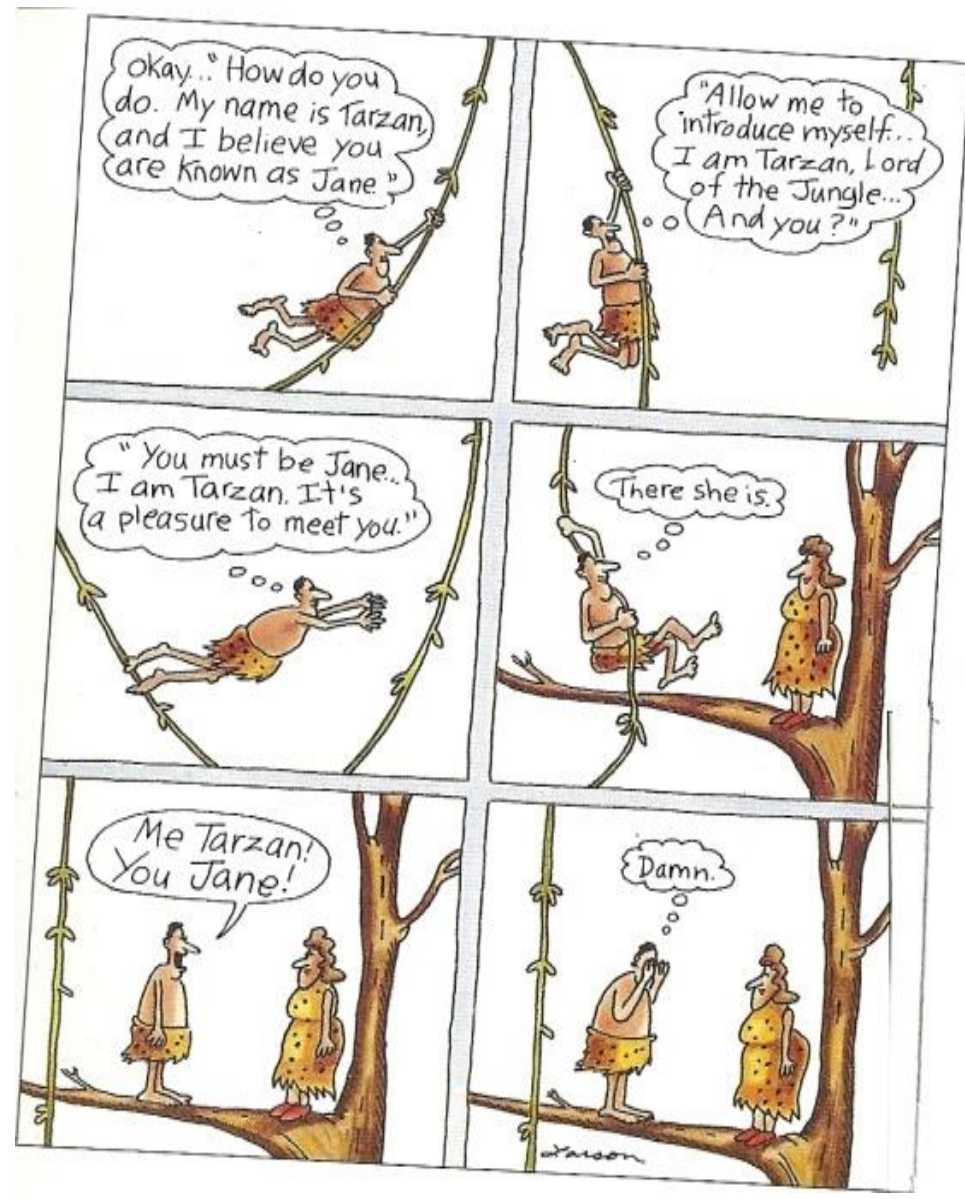

Figura 5: O bordão de Tarzan ${ }^{92}$

O linguista britânico David Crystal (1997, p. 179) observa que apesar de esta expressão, que ele denomina "frase de efeito mítica" (mythical catch phrase) ser falsa, a

\footnotetext{
${ }^{90}$ Op. cit.

${ }^{91}$ Ilustrada, E 12, Folha de São Paulo. 12/04/2014.

${ }^{92}$ In: CRYSTAL, David op. cit.
} 
comunicação entre Tarzan e Jane ocorria de forma elíptica e desarticulada em algumas produções cinematográficas. Vale observar que a imagem depreciativa da obra de Burroughs influenciada por esse "rebaixamento de registro" nas transposições semióticas de Tarzan e aliada ao desprezo por parte da crítica, pode ter gerado uma expectativa negativa nos tradutores brasileiros influenciando a tradução.

Se por um lado o cinema e os quadrinhos ajudaram a popularizar a obra de Burroughs, por outro contribuiram para estigmatiza-la. O texto de Burroughs, apesar de não ter uma dimensão literária distintiva, é correto e formal - nota-se especificamente o uso de grande número de palavras de origem latina em detrimento do Anglo-Saxão, como commencae effluvium e expressões poéticas como Cimmerian oblivion e Stygian nights. Crystal (1997, p, 124) esclarece que, desconsiderando as diferenças de sentido entre as palavras de origem anglo-saxônica e as correspondentes latinas, pois não há sinonímia perfeita, as formas latinas são mais formais, literárias e polidas no inglês. Isso porque estas são menos frequentes, sendo que os lexemas Anglo-Saxões, mesmo abarcando apenas uma parte relativamente pequena do total do léxico moderno, fornecem quase que a maioria das palavras usadas no dia a dia.

Nas histórias de Burroughs, o herói é um órfão perdido na selva e criado por uma macaca, mas que consegue aprender o inglês sem ter nunca tido contato com falantes do idioma. Aprende a ler nos livros que encontra no abrigo construído por seus falecidos pais. Consequentemente, por meio da língua Tarzan se descobre misto de homem e besta. Inteligente e fluente em inglês, também fala a língua dos animais e de seres humanoides que habitam suas histórias. Foi criado por Burroughs um vocabulário novo que tem como efeito levar a imaginação do leitor aos mais estranhos cenários. Alguns dos livros até trazem um glossário de línguas fictícias, como em Tarzan, the terrible.

Longe de ser primitivo, Tarzan tem uma personalidade que oscila de sentimentos mais nobres de uma linhagem fidalga a hábitos selvagens e atitudes ferozes. Para Ruy Castro (2014), o herói surge na primeira história como "um Tarzan em conflito e que tem que escolher entre reassumir sua persona de lorde Greystoke em Londres ou seu trono entre os macacos. Um doce bárbaro". Burroughs, em entrevista à revista Writer's Digest, em 1932 (LACASSIN, 1971, p. 214) esclarece que ao criar a lenda de Tarzan queria evocar a luta entre hereditariedade e ambiente. Imaginou uma criança marcada pelas características hereditárias do tipo mais puro e nobre com idade em que ainda pudesse ser influenciada pelo meio. 
O ancestral mito da criança selvagem adotada por animais é fonte de inspiração de Burroughs. O próprio autor confirma ter se baseado na lenda de Rômulo e Remo em uma entrevista publicada em 22 de junho de 1939 em The Saturday Evening Post (LACASSIN, 1971, p. 215). Quanto à influência de Kipling, Burroughs não a admite claramente, mas confirma que leu O livro da selva. Talvez o que mais separe Kipling de Burroughs seja o público alvo: o do autor inglês eram crianças da elite cultural e do americano, um vasto público de jovens e adultos. Para Lacassin (1971, p. 53), a personagem Tarzan segue o arquétipo da criança reencontrada conforme a fórmula dos romancistas populares, de Eugène Sue a Marcel Allain, passando por Hector Malot, entretanto, "Tarzan se parece cada vez menos com Mogli na medida em que se despe de sua personalidade de vítima em favor daquela de justiceiro e explorador do fantástico" 93 (p. 216). A estrondosa recepção das histórias faz com que Tarzan se desprenda de suas fontes e chegue à posteridade como uma história fantástica e original e, provavelmente, como o primeiro super-homem da ficção, conforme alcunha dada por Burroughs em Tarzan, o filho das selvas, no capítulo 24: "Admito que talvez valha a pena esperá-lo, esse seu super-homem - riu o capitão - Eu certamente gostaria de conhecê-lo" (2014, p. 272).

Mas como todos os protagonistas da literatura ligeira, Tarzan é personagem plana, sem densidade psicológica. Nesse tipo de narrativa o que importa é o desenvolvimento da ação e a maneira como o herói consegue dominar o cenário hostil (MOISÉS, 1967, p. 298). Em se tratando de histórias em sequência o leitor sabe de antemão que Tarzan sairá vencedor, mas o suspense reside em como ele fará para escapar dos perigos e armadilhas.

Herói de uma mitologia moderna, Tarzan rejeita a sociedade e se embrenha numa África tão imaginada quanto as míticas cidades criadas por Burroughs. A fauna nos relatos de Burroughs consiste em espécies reais, inventadas e extintas vivendo ao lado de pitecantropos, humanóides, trogloditas, europeus, negros e árabes. Abandonando o mundo real, Burroughs faz com que o mito deambule por outra dimensão, sem preocupação com a cronologia ou com a lógica. Em algumas histórias ecoa debilmente o mundo real, como as alusões à Rússia soviética, aos nazistas, às guerras coloniais. Esse ambiente, povoado de criaturas estranhas e civilizações perdidas, serve de cenário para o herói, cuja inerente capacidade mental e nobres valores

\footnotetext{
${ }^{93}$ Tarzan ressemble de moins en moins à Mowgli à mesure qu'il dépouille sa personnalité de victime au profit de celle du redresseur de torts et sourcier du fantastique.
} 
colocam-no acima dos amigos e inimigos, selvagens ou civilizados, e do inóspito ambiente.

Segundo o ilustrador dos primeiros quadrinhos, Burne Hogarth ${ }^{94}$, o homemmacaco, ao se distanciar do patrimônio, da riqueza, do luxo, rejeita também as consequências da sociedade "civilizada": a escravidão, a guerra, a ambição e o poder manipulativo. Sua autoridade não pode ser contestada, pois desde os dezoitos anos Tarzan se auto-proclama rei das selvas. Tarzan luta contra a escravidão e não admite o domínio do homem branco sobre o negro. Paradoxalmente, o herói assume o paternalismo complacente próprio do colonizador. Nesse contexto, os bons elementos são europeus, notadamente os franceses ou ingleses. Os bons negros são aqueles que servem a Tarzan, como os Waziris, belos, fortes leais e corajosos; os maus negros são sujos, feios, supersticiosos e canibais.

As histórias de Tarzan reproduzem os clichês colonialistas da supremacia da raça branca sobre os outros povos e o herói representa o guerreiro de linhagem nobre ideal em época de adeptos da eugenia. Em $O$ tesouro de Tarzan, os árabes são inimigos hereditários (hereditary enemies) que odiavam todos os europeus (hater of all Europeans), numa rivalidade que data das Cruzadas. A religião é polarizadora da hostilidade: para os árabes os europeus são "cachorros cristãos" (despised dog of a Christian).

Vale lembrar que Burroughs vivenciou a colonização do meio-oeste americano e, ainda por cima, integrou um exército que a todo custo procurava subjugar os nativos e a natureza. Nas histórias de Tarzan, a maneira como os europeus se referem aos árabes "cortadores de garganta" (cut-throaters) - replica em cenário africano a selvageria pela qual os índios americanos ficaram famosos, o escalpo. A visão de mundo de Burroughs se reflete em suas histórias, mesmo que estas se passem em lugares e culturas que o autor não conheceu.

Muitas são as leituras que se fazem do herói meio selvagem, meio civilizado. Aparentemente inocente, a série Tarzan mereceu uma análise menos simplista de Eric Cheyfitz (1991, p.3), alinhando essas histórias com os estudos pós-coloniais ao argumentar elas articulam os anseios mais profundos da política externa dos Estados Unidos com relação ao Terceiro Mundo, no século 20. A superpotência seria o equivalente do herói de Burroughs, que fala corretamente a língua da civilização e

\footnotetext{
${ }^{94}$ In: Francis LACASSIN, Tarzan ou le chevalier crispé, p. 13.
} 
abraça o conceito da democracia capitalista, vendo no "bárbaro" e no "selvagem" a representação da figura do "comunista" e do "terrorista", os quais devem ser submetidos a valores mais "nobres".

Todavia, a análise do jornalista e escritor francês, Francis Lacassin (1971, p. 19), é menos política. Para este especialista em romance popular e quadrinhos, como "os homens não tem os mitos que merecem, mas aqueles que lhes são necessários" ${ }^{95}$, daí a necessidade de se criar as lendas de super-heróis. Tarzan recria espaços de sonhos, simboliza a liberdade selvagem sem quaisquer coerções sociais, numa sociedade industrial e febril do início do século 20. De uma maneira ou de outra, a criação de Burroughs permite toda sorte de análise e comparações, mas não se pode negar que, apesar de toda a crítica à sua qualidade literária, as histórias de Tarzan publicadas em forma de romance foram um fenômeno editorial, atingindo uma grande massa de leitores em todo o mundo, que por meio das aventuras se imaginavam errantes e livres, senhores de seu próprio destino, como Tarzan.

\subsection{O Tarzan brasileiro}

A primeira vez que Tarzan aportou no Brasil foi em 1933 com a publicação de Tarzan o filho das selvas, traduzido por Álvaro Eston da primeira história original, Tarzan of the apes. Das vinte e seis histórias escritas por Burroughs, a Companhia Editora Nacional lançou dezoito obras no total sendo que dezesseis em sequência entre 1933 e 1937. As reedições, que somam até oito do mesmo título, se estendem até 1968.

\begin{tabular}{|l|c|l|c|c|c|}
\hline \multicolumn{1}{|c|}{ Título original } & Título no Brasil & \multicolumn{1}{|c|}{ Tradutor } & $\begin{array}{c}\text { Primeira } \\
\text { publicação }\end{array}$ & $\begin{array}{c}\text { Última } \\
\text { publicação }\end{array}$ & $\begin{array}{c}\mathbf{N}^{\mathbf{0}} \text { de } \\
\text { edições }\end{array}$ \\
\hline Tarzan of the Apes & $\begin{array}{c}\text { Tarzan, O Filho das } \\
\text { Selvas }\end{array}$ & Álvaro Eston & 1933 & 1968 & 8 \\
\hline The Return of Tarzan & A Volta de Tarzan & Murillo Torres & 1933 & 1968 & 7 \\
\hline The Beasts of Tarzan & As feras de Tarzan & $\begin{array}{l}\text { Medeiros de } \\
\text { Albuquerque }\end{array}$ & 1933 & 1968 & 7 \\
\hline The Son of Tarzan & O filho de Tarzan & Godofredo Rangel & 1934 & 1968 & 7 \\
\hline $\begin{array}{l}\text { Tarzan and the Jewels } \\
\text { of Opar }\end{array}$ & O Tesouro de Tarzan & Manuel Bandeira & 1934 & 1968 & 7 \\
\hline
\end{tabular}

\footnotetext{
${ }^{95}$ Les hommes n'ont pas les mythes qu'ils méritent, mais ceux dont ils ont besoin.
} 


\begin{tabular}{|c|c|c|c|c|c|}
\hline Jungle Tales of Tarzan & Tarzan na Selva & Azevedo Amaral & 1934 & 1968 & 8 \\
\hline Tarzan, The Untamed & $\begin{array}{l}\text { Tarzan, O Destemido } \\
\text { vol. } 1 \text { e } 2\end{array}$ & $\begin{array}{l}\text { Basílio de } \\
\text { Magalhães }\end{array}$ & 1935 & 1956 & 4 \\
\hline Tarzan, The Terrible & Tarzan, O Terrível & Monteiro Lobato & 1935 & 1968 & 7 \\
\hline $\begin{array}{l}\text { Tarzan and the Golden } \\
\text { Lion }\end{array}$ & $\begin{array}{l}\text { Tarzan e o Leão de } \\
\text { Ouro vol. } 1 \text { e } 2\end{array}$ & Azevedo Amaral & 1935 & 1956 & 4 \\
\hline $\begin{array}{l}\text { Tarzan and the Ant } \\
\text { Men }\end{array}$ & $\begin{array}{l}\text { Tarzan e os Homens } \\
\text { Formigas }\end{array}$ & Paulo de Freitas & 1935 & 1958 & 5 \\
\hline $\begin{array}{l}\text { Tarzan, Lord of the } \\
\text { Jungle }\end{array}$ & $\begin{array}{l}\text { Tarzan, O Rei da } \\
\text { Jângal }\end{array}$ & Godofredo Rangel & 1935 & 1968 & 6 \\
\hline $\begin{array}{l}\text { Tarzan and the Lost } \\
\text { Empire }\end{array}$ & $\begin{array}{l}\text { Tarzan e o Império } \\
\text { Perdido }\end{array}$ & $\begin{array}{l}\text { Basílio de } \\
\text { Magalhães }\end{array}$ & 1936 & 1968 & 5 \\
\hline $\begin{array}{l}\text { Tarzan at the Earth's } \\
\text { Core }\end{array}$ & $\begin{array}{l}\text { Tarzan no Centro da } \\
\text { Terra }\end{array}$ & Monteiro Lobato & 1936 & 1956 & 4 \\
\hline Tarzan, the Ivincible & Tarzan, O Invencível & Paulo de Freitas & 1937 & 1959 & 5 \\
\hline Tarzan Triumphant & Tarzan Triunfante & Paulo de Freitas & 1937 & 1959 & 4 \\
\hline $\begin{array}{l}\text { Tarzan, The } \\
\text { Magnificent }\end{array}$ & Tarzan, O Magnífico & Jan Costa & 1939 & 1959 & 4 \\
\hline $\begin{array}{l}\text { Tarzan and the City of } \\
\text { Gold }\end{array}$ & $\begin{array}{l}\text { Tarzan e a Cidade de } \\
\text { Ouro }\end{array}$ & Azevedo Amaral & 1940 & 1956 & 5 \\
\hline $\begin{array}{l}\text { Tarzan and the } \\
\text { Leopard Men }\end{array}$ & $\begin{array}{l}\text { Tarzan e os Homens } \\
\text { Leopardos }\end{array}$ & $\begin{array}{l}\text { José Geraldo } \\
\text { Vieira }\end{array}$ & 1948 & 1959 & 4 \\
\hline
\end{tabular}

Tabela 1: Relação de título de Tarzan publicados pela Cia. Editora Nacional ${ }^{96}$

Assim como nos Estados Unidos, no Brasil o cinema foi grande promotor da personagem Tarzan. Desde início dos anos 20, no eixo Rio-São Paulo, "ir ao cinema pelo menos uma vez por semana, vestido com a melhor roupa, tornou-se obrigação para garantir a condição de moderno e manter reconhecimento social" (SEVCENKO, 1980, p. 599). Entretanto, o cinema americano ganharia mais impulso com as dificuldades financeiras de seus concorrentes europeus durante o pós-guerra e a década de 1930 viria a ser, além da "era do cinema". Nesse período, cinema nesse período passa a significar Hollywood, pois as distribuidoras de filmes norte-americanos no Brasil investem muito dinheiro em publicidade e na aparelhagem de som das casas de projeção e, por meio de

\footnotetext{
${ }^{96}$ Fontes: http://www.ednacional-acervo.com.br/consulta.asp e http://www.estantevirtual.com.br/ Acesso 21/11/2013.
} 
um "monopólio" de criação e distribuição de filmes, difunde e estabelece padrões de beleza e comportamento.

O cinema hollywoodiano é sedutor, "é uma arte feita para os olhos e o subconsciente, não para a razão ou a explanação verbal" (SEVCENKO, 1980, p. 600). Até a elite intelectual, como Carlos Drummond de Andrade (1996, p. 85-86), sente-se atraída por ele, que neste trecho do poema "Os 27 filmes de Greta Garbo" confirma o poder imagético da chamada sétima arte:

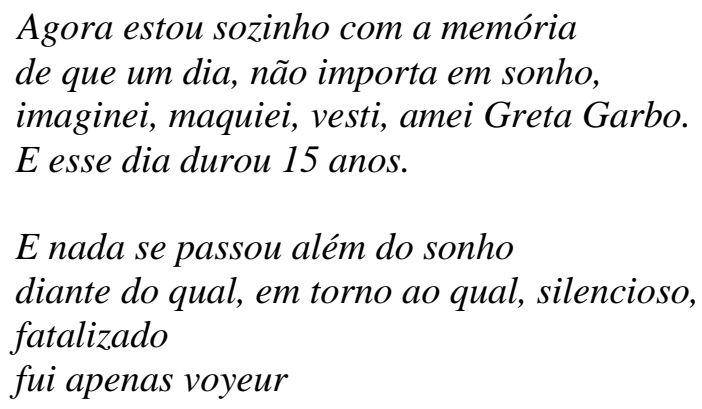

Muitas obras de todos os gêneros literários são levadas às telas e aproveitando-se do sucesso no cinema, algumas editoras nacionais lançam traduções desses livros. Dentre as adaptações vale mencionar o romance alemão de ficção científica Der Tunnel, de Bernhard Kellermann, de 1913, mas lançado no cinema na década de 1930, e que teve sua tradução a cargo de Manuel Bandeira em 1938. Também com tradução de Bandeira, de 1934, The calendar, de Edgar Wallace, teve duas versões cinematográficas, 1931 e 1948. A woman of affair (1928) do romance homônimo de Michael Arlen foi outro filme que conheceu o sucesso, principalmente devido à participação de Greta Garbo, e que talvez tenha motivado a tradução do romance por Manuel Bandeira com o título de Uma mulher de brio, em 1937.

Uma pesquisa realizada em 1949 na Biblioteca Pública Municipal de São Paulo apurou que, com relação ao leitor infantil, "a antecedência da fita sobre o livro é percentualmente de 52,5\%, sendo que a do livro sobre a fita é de 40\%" (DE CICCO, 1979, p. 80). No que concerne ao público adulto, a equação de causalidade é mais evidente na referência ao livro nos cartazes de cinema e na lista dos nomes do elenco do filme na primeira página do livro, em correspondência com a das personagens do romance, levando o leitor a atribuir um rosto às personagens fictícias, "emprestandolhes a fisionomia das estrelas que as personificavam na tela" (p. 81). 
Relata Cláudio De Cicco (1979, p. 82) que Érico Veríssimo escreve no Diário da Noite (11/10/1940): "O cinema está contribuindo para aumentar entre os paulistanos o interesse pelas literaturas norte-americana e inglesa". Nota-se que, ao lado do rádio, o cinema torna-se fonte importante de transformação cultural, fomentando novos estilos de vida e hábitos de consumo. As editoras atentas ao fato atrelam-se a essas novas manifestações para promover suas publicações. Para Monteiro Lobato a editora pioneira em publicações de "livros arejados, cinematográficos, de cenário amplíssimo - não mais a alcova de Paris" foi a Companhia Editora Nacional, que "aventurou-se a lançar no mercado Wren, Wallace, Bourroughs (sic), Stevenson, e que tais" (1955c, p. 126), demandando cada vez mais tradutores.

Somem-se à influência do cinema na indústria livreira as consequências que o conflito mundial acarretou:

A proliferação de obras de autores norte-americanos foi favorecida pelo estancamento das tradicionais fontes de fornecimentos de livros importados, como Paris, Leipzig e outros centros europeus assolados pela segunda guerra mundial. Os estoques de romances traduzidos ou importados no original francês esgotaramse. O público leitor de romances tinha disponíveis obras norte-americanas (KOSHIYAMA, 1982, p. 155).

O lançamento dos livros da série Tarzan no Brasil coincide com a produção cinematográfica sonora das histórias de Tarzan, e com tal sucesso que os filmes eram reprisados e os livros reeditados. Conforme se verifica na propaganda da época veiculada na mídia impressa:

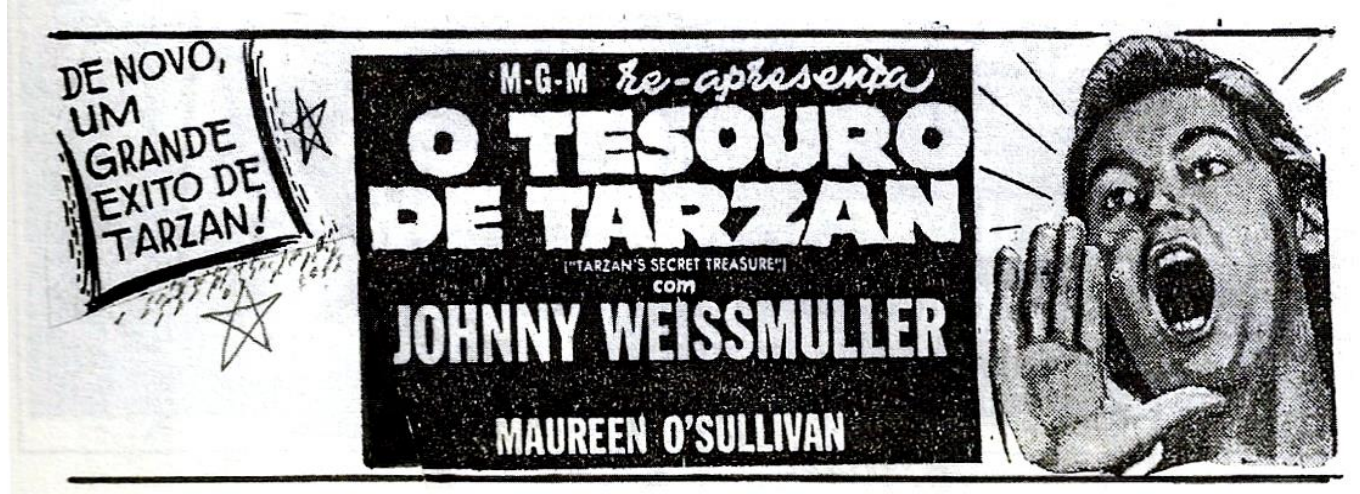

Figura 6: Cartaz do filme "O tesouro de Tarzan" 97

\footnotetext{
${ }^{97}$ In: Silva; Losso \& Sakamoto, p. 115.
} 
Em um período de mudanças socio-culturais, as histórias de Tarzan no cinema falado, protagonizadas primeiramente pelo nadador olímpico Johnny Weismüller, contribuíram para que a imagem do herói viril criada na mente dos leitores pela descrição verbal, e concretizada nas telas do cinema, se tornasse símbolo de beleza masculina e de saúde. Nicolau Sevcenko (1980, p. 568) avalia que: "Para os jovens anônimos, os esportes e a exuberância física do corpo atlético criaram novas oportunidades de visibilidade no espaço público e possibilidades inéditas de ascensão social". A moda, em resposta a essa nova estética física masculina, lança os paletós com ombreiras e um corte que acentuava o peito e afinava a cintura. A busca da elegância se justifica na medida em que "a aparência se torna o cartão de apresentação, legitimando sua aspiração aos bens e às posições. Juventude, beleza, elegância e estilo se tornam os requisitos do sucesso na nova sociedade" (SEVCENKO, 1998, p. 538).

Em 1936, Noel Rosa, cronista de seu tempo, não fica indiferente e satiriza a tendência compondo, juntamente com Vadico, "Tarzan, o filho do alfaiate", música que foi incluída no filme "Cidade Mulher", interpretado pelo comediante José Vieira e dirigido por Humberto Mauro.

\section{TARZAN, O FILHO DO ALFAIATE}

Quem foi que disse que eu era forte?

Nunca pratiquei esporte, nem conheço futebol...

O meu parceiro sempre foi o travesseiro

E eu passo o ano inteiro sem ver um raio de sol

A minha força bruta reside

Em um clássico cabide, já cansado de sofrer

Minha armadura é de casimira dura

Que me dá musculatura, mas que pesa e faz doer

Eu poso pros fotógrafos, e distribuo autógrafos

A todas as pequenas lá da praia de manhã

Um argentino disse, me vendo em Copacabana:

'No hay fuerza sobre-humana que detenga este Tarzan'

De lutas não entendo abacate

Pois o meu grande alfaiate não faz roupa pra brigar

Sou incapaz de machucar uma formiga

Não há homem que consiga nos meus músculos pegar

Cheguei até a ser contratado

Pra subir em um tablado, pra vencer um campeão

Mas a empresa, pra evitar assassinato

Rasgou logo o meu contrato quando me viu sem roupão 
Quem foi que disse que eu era forte?

Nunca pratiquei esporte, nem conheço futebol...

$O$ meu parceiro sempre foi o travesseiro

E eu passo o ano inteiro sem ver um raio de sol.

O samba, além de satirizar o comportamento social e a nova tendência da moda, também ajudou a divulgar a figura de Tarzan. As histórias de Tarzan tornaram-se populares e o seu físico apolíneo foi tomado como modelo a ser buscado. Para a divulgação dessa música nada melhor que a veiculação pelo rádio, um recurso que, principalmente a partir dos anos 1930, teve um impacto decisivo para a transformação da cultura, pois descobriria seu potencial na transmissão de música popular brasileira, (SEVCENKO, 1998, p. 588). O aparelho de rádio passa a ser de consumo popular e deixa de ser exclusividade da elite e, dentre todos os gêneros musicais o preferido é o samba "embora causasse algumas inquietaçõs ao regime devido à sua irreverência, origem boêmia e ao elogio que fazia à malandragem com sua suposta vocação para a indisciplina e insubordinação" (DUTRA, 2013, p. 263). O radio, veiculando o samba de Noel, assim como o cinema, pode ter contribuido para tornar Tarzan tão familiar aos brasileiros a ponto de o leitor praticamente se esquecer de que se tratava de tradução.

Além dos filmes para cinema, foi criada na década de 1960 uma série para televisão. Nela Tarzan, cansado da civilização, volta à selva onde convive com um menino órfão, Jai e sua macaca Cheetam. Com o programa exibido no Brasil no início dos anos 1970, a Editora Record compra os direitos dos seguintes títulos da coleção pagando a Companhia Editora Nacional onze mil cruzeiros por eles ${ }^{98}$ : Tarzan e o homem-formiga; Tarzan e o centro da terra; Tarzan, o invencível; Tarzan e a cidade de ouro; Tarzan e os homens leoprado; Tarzan triunfante; Tarzan, o magnífico; Tarzan e o leão de ouro.

Vida longa ao Tarzan. Tarzan parece ter sido "o primeiro super-herói o primeiro ícone do mundo pop a alcançar uma difusão que se tornaria mundial", conforme declara Thiago Lins (2014) ${ }^{99}$. Ainda em 1979, o leitor Isaias Fernandes dos Santos, de Americanópolis, no estado de São Paulo, escreve à Companhia Editora Nacional procurando por livros de Tarzan, então esgotados. O superintendente comercial da Editora Nacional, José Roberto Breves, aconselha-o a procurar na Livraria Teixeira,

\footnotetext{
${ }^{98}$ Fonte: Acervo da Companhia Editora Nacional na UNIFESP, campus Guarulhos.

${ }^{99}$ Op. cit
} 
então na Rua Marconi, "que comercializa livros de todos os tipos e poderá dispor ainda, não da coleção, mas de exemplares isolados, se tiver" ${ }^{100}$.

Para muitos da nova geração Tarzan é obra do estúdio Disney, que recria a história em um desenho em longa metragem, em 1999. Em março de 2014, a editora Zahar lança Tarzan, o filho das selvas, em comemoração aos 100 anos do lançamento da primeira história em livro.

Desqualificada enquanto "literatura", essa obra de Burroughs pode apresentar um caráter transitório, mas não se pode negar seu valor iniciático. Muitos desenvolveram gosto pela leitura levados pelo homem-macaco. Caio Fernando Abreu no conto "O pequeno monstro" narra a história de um jovem de "pernas e braços demais, pêlos nos lugares errados, uma voz que desafinava igual de pato, eu queria me esconder de todos". Como "não suportava ninguém por perto", encontra na leitura de Tarzan, o invencível refúgio para os problemas da adolescência:

Desviei os olhos para o livro de Tarzan, o Invencível, na cabeceira. Em cima duma árvore, Tarzan apontava uma flecha para um bwana falando com dois negros pigmeus na frente de uma barraca. E se ele disparar a flecha? pensei (ABREU, 1988, p.142).

Ruy Castro (Suplemento do Jornal de Pernambuco, 2014) ${ }^{101}$ se diz íntimo de Tarzan há 60 anos. "Li-o pela primeira vez aos seis anos, em 1954, na edição da Coleção Terramarear. Em entrevista à "folha Ilustrada" do jornal Folha de São Paulo 102 Castro ralata: "Foi o primeiro livro que comprei. E devo ter gostado, porque a ele se seguiram outros 19 livros da série". O prazer pela leitura levou-o a outros autores: "descobri o Sherlock Holmes, depois o Arsène Lupin, mergulhei em muito capa-eespada".

A história de Tarzan por sua narrativa linear, maniqueísta e tão fantástica quanto um conto de fadas leva Lobato a comentar com Godofredo Rangel, antes mesmo de o primeiro volume ter sido publicado no Brasil: "Conheces a série Tarzan? Curiosa e bem infantil. Anda a milhões. Eu me acho capaz de escrever para os Estados Unidos por causa do meu pendor para escrever para crianças" (LOBATO, 1957b, p. 294). Parece que Lobato mesmo admirando a sociedade americana não tinha em alta conta o intelecto de seus membros.

\footnotetext{
${ }^{100}$ Fonte: Carta em acervo da Companhia Editora Nacional, UNIFESP, campus Guarulhos.

101 http://www.suplementopernambuco.com.br/index.php/edicoes-anteriores/9.html Acesso 28/03/2014.

${ }^{102}$ Ilustrada, E12, Folha de São Paulo, 12/04/2014.
} 
Menos preocupado com o público leitor, Manuel Bandeira vive momentos lúdicos durante a tradução de Tarzan:

Ando numa grande distração de espírito traduzindo o Tarzan (Tarzan e as jóias de Opar). É o tipo da coisa gozada. Como descansa das complicações e perplexidades da vida: sujeito ruim é ruim mesmo nestes romances populares de aventuras. Neste tem um tenente belga que é uma peste! As feras são deliciosamente ferozes. Há dez dias que vivo assim no centro da África, "na região mais selvagem que jamais existiu à face do Globo'..." ${ }^{103}$.

Os tradutores das obras de Tarzan escolhidas para análise deste estudo são figuras contemporâneas, cujos nomes gozavam de prestígio num momento em que o círculo de pessoas culturalmente favorecidas ainda era restrito, Não obstante, divergem em vários aspectos. Primeiramente, não formam um grupo homogêneo com relação à produção literária própria: Manuel Bandeira era sobretudo poeta; Monteiro Lobato ganhou fama com a literatura infantil e com contos para adultos; e Godofredo Rangel é considerado um escritor realista sem muita expressividade. Com relação à atividade tradutória, Bandeira teoriza quase que exclusivamente sobre a poética e Lobato se preocupa com o leitor e percebe a necessidade da tradução de prosa ficcional. Das opiniões de Godofredo Rangel o que se sabe é através das respostas de Lobato na correspondência que mantiveram por quarenta anos. Enéas Athanázio (1977, p. 11) lamenta que "reina sobre ele um triste silêncio, sua obra cai no esquecimento...". Contudo, Rangel é autor de inúmeras traduções.

\subsection{Os tradutores}

\subsubsection{Manuel Bandeira: um tradutor à sombra do poeta}

Muito pouco foi investigado sobre a atividade de Bandeira como tradutor, principalmente no que se refere à prosa. O próprio Bandeira, apesar de exercer tantas atividades relacionadas às letras, se considerava antes de tudo poeta e declarava: "Poesia, minha vida verdadeira" ${ }^{104}$. Com uma trajetória que se inicia nas concepções do neoparnasianismo e neossimbolismo, sua poética passa pelo modernismo de Libertinagem e chega a experiências de sabor concretista, como os poemas em Composições. Trata-se de uma poética que é fruto tanto da leitura como da tradução de

\footnotetext{
${ }^{103}$ Carta de MB a MA de 30/08/1934.

${ }^{104}$ Do poema Estrela da vida inteira.
} 
poemas. Bosi (2004, p. 365) avalia que a longa e íntima convivência do poeta "com o melhor do que lhe poderia dar a literatura de todos os tempos e países", forjou o "tradutor de várias línguas, mestre de cultura hispano-americana", deixando um legado ímpar. Mas, para Bandeira (1966, p. 27) não foi somente a boa poesia que o influenciou: "Devo dizer que aprendi muito com os maus poetas. Neles, mais do que nos bons, se acusa o que devemos evitar".

Ao que parece, Bandeira iniciou a atividade de tradutor para jornais e revistas, conforme indica uma carta do poeta a Mário de Andrade, na década de 20: "E adeus, que já escrevi hoje 22 tiras de tradução para uma revista" ${ }^{105}$. Para José Paulo Paes (1990, p.55), no entanto, "A biografia de Bandeira tradutor começa evidentemente pelo seu aprendizado de línguas estrangeiras", que, como muitos afortunados contemporâneos, estudou em escolas com corpo docente formado por europeus. Também sua estada no sanatório de Clavadel, na Suíça contribuiu para o aperfeiçoamento do francês e do alemão.

Na década de 30, o poeta inicia o trabalho regular em tradução para uma agência de notícias: "Começara eu a trabalhar à noite como tradutor de telegramas da United Press. Lembro-me que eram meus companheiros, entre outros, Sérgio Buarque de Holanda e Afonso Várzea" ${ }^{106}$. O trabalho apesar de cansativo e com horário irregular, não exigia esforço intelectual, conforme relata Bandeira: "O trabalho da United Press é suportável (e até moralmente me faz muito bem: cinco horas em que não penso absolutamente em nenhuma amolação da vida!), mas é preciso que o resto do tempo eu descanse" ${ }^{107}$. Preocupado com a fragilidade física do amigo, Mário de Andrade demonstra sua preocupação: "O caso de você estar trabalhando na agência, meu Deus, vamos a ver! Em todo caso repouso em você quanto a perceber se está se fatigando muito e estragando o corpo. Tome cuidado" ${ }^{108}$.

O grande número de traduções de Bandeira ilustra o esforço intelectual e físico que representava para alguém que se dizia "quase inválido" (BANDEIRA, 1966, p. 7) pelas "lesões incompatíveis com a vida" (p. 138), em uma época sem os recursos tecnológicos de nossos dias. Para Bandeira essa atividade era sempre muito desgastante e confessa: "traduzir é sempre dificílimo" ${ }^{109}$. O poeta relata a Mário o cansaço que o

\footnotetext{
${ }^{105}$ Carta de MB a MA de 19/01/1925.

${ }^{106}$ In: Correspondência: Mário de Andrade \& Manuel Bandeira. p. 533, notas.

${ }^{107}$ Carta de MB a MA de 03/12/1931.

${ }^{108}$ Carta de MA a MB de 06/11/1931.

${ }^{109}$ Carta de MB a MA de 21/05/1928.
} 
trabalho lhe proporciona: "Embora a minha máquina seja uma Royal portátil, macia que faz gosto, depois da tarefa cotidiana [de traduzir], eu não tinha mais força nem vontade para escrever mais nada" ${ }^{110}$. Mesmo assim ele demonstra levar o trabalho a sério ao dizer para o amigo que "não queria fazer feio" ${ }^{111}$, apesar de o livro a traduzir ser de literatura de entretenimento.

Nesse mesmo período, a tradução passa a tomar boa parte do tempo de Bandeira, forçando-o a deixar de lado outras atividades: "Tive que abandonar a colaboração do Estado de Minas" ${ }^{112}$, conta Bandeira quando já trabalhava para a Companhia Editora Nacional. Seis meses depois, a faina persiste: "Agora vou-lhe explicar por que demorei tanto em lhe escrever. Depois que o Ribeiro Couto entrou de sócio para a Civilização Brasileira, fui convidado a fazer traduções e revisões para a casa" ${ }^{113}$. Em 1937, Octalles Marcondes Ferreira, então diretor da paulista Companhia Editora Nacional, adquire a Civilização Brasileira e Bandeira continua traduzindo para ambas as casas.

Bandeira foi um tradutor profícuo e poliglota, sendo que o ecletismo de suas traduções se encontra tanto nos gêneros (traduziu poesia, teatro e prosa) quanto nas diversas línguas (alemão, francês, inglês e espanhol). O mapeamento dos títulos traduzidos revelou um total de dezessete publicações em prosa (ficção e não ficção), treze peças teatrais (dramas clássicos e comédias leves) e vários poemas publicados em revistas literárias e jornais e, posteriormente, reunidos em Poemas Traduzidos (110 a 136 poemas, conforme a edição), além de dois longos poemas (Rubayat, de Omar Khayyam e Miréia, do prêmio Nobel Frédéric Mistral).

Manuel Bandeira enquanto tradutor de poesia foi um recriador à altura do poeta. Mediada por Bandeira a tradução, frequentemente, revela o seu caráter transformacional envolvendo vários tipos de transposição de um código linguístico para outro. Em algumas ocasiões, Bandeira, tomando a tradução de uma perspectiva mais ampla, que a aproxima da adaptação, da paráfrase e da paródia, produz formas de reescritura fortemente autorais. São exercícios criativos que ele denomina "traduções para o moderno": uma de um soneto de Bocage e a outra de um poema de Castro Alves, que foram publicadas, numa mesma tiragem, na seção "Mês Modernista" do jornal A Noite, em 1925. Tratava-se de uma galhofa por não levar muito a sério a incumbência de

\footnotetext{
${ }^{110}$ Carta de MB a MA de 01/05/1934.

${ }^{111}$ Carta de MB a MA de 16/12/1933.

112 Carta de MB a MA de 29/11/1933.

${ }^{113}$ Carta de MB a MA de 01/05/1934.
} 
participar no movimento literário que despontava: "o que fiz foi me divertir ganhando cinquenta mil-réis por semana, o primeiro dinheiro que me rendeu a literatura" (BANDEIRA, 1966, p. 92).

$\mathrm{Na}$ recriação de um soneto de Bocage ${ }^{114}$, é na espacialização dos versos, replicando a sinuosidade do rio e sugerindo o fluxo das águas, de sua "tradução para o moderno" que fica sugerida a leve ironia:

Doçura, no estio recente,

Ver a manhã toucar-se de flôres,

E o rio

mole

queixoso

Deslizar, lambendo areias e verduras:

Doçura de ouvir as aves

Em desafio de amôres

cantos

risadas

Na ramagem do pomar sombrio

Bandeira (1966, p. 92) explica o seu intento de crítica: "Como se vê, eu estava assinalando maliciosamente certas maneiras de dizer, certas disposições tipográficas que já se tinham tornado clichês modernistas". Em outra "tradução para o moderno", Adeus $a_{\text {Teresa }}{ }^{115}$, de Castro Alves, Bandeira não só atualiza a forma como parodia o tema conferindo-lhe um "tom" de mais humor:

A primeira vez que vi Teresa

Achei que ela tinha pernas estúpidas

Achei também que a cara parecia uma perna

Quando vi Teresa de novo

Achei que os olhos eram muito mais velhos que o resto do corpo

\footnotetext{
${ }^{114}$ Se é doce no recente, ameno Estio/Ver toucar-se a manhã de eternas flores/E, lambendo as areias e os verdores, Mole e queixoso deslizar-se o rio;/ Se é doce e inocente o desafio/ Ouvirem-se os voláteis amadores/Seus versos modulando e seus ardores/Dentre os aromas de pomar sombrio/Se é doce mares, céus ver anilados/Pela quadra gentil de amor querida/ Que esperta os corações, floreia os prados/Mais doce é ver-te de meus ais vencida/ Dar-me teus brandos olhos desmaiados/Morte, morte de amor, melhor que a vida.

${ }^{115}$ A primeira vez que vi Teresa/ Como as plantas que arrasta a correnteza/ A valsa nos levou nos gritos seus/ E amamos juntos... e depois na sala/ Adeus eu lhe disse a tremer co'a fala/ E ela corando murmurou-me: "adeus"/ Uma noite...entreabriu-se um reposteiro.../E da alcova saia um cavaleiro/ Inda beijando uma mulher sem véus/ Era eu... Era pálida Teresa/ "Adeus" lhe disse conservando-a presa/ E ela entre beijos murmurou-me "adeus"!/ Passaram-se tempos... séculos de delírio/ Prazeres divinais... gozos de Empíreo.../ Mas um dia volvi aos lares meus/ Partindo eu disse: - "Voltarei! descansa!"/ E ela chorando mais que uma criança/ E ela em soluços murmurou-me: 'adeus"/ Quando voltei... era o palácio em festa!/ E a voz d'Ela e de um homem lá na orquestra/ Preenchiam de amor o azul dos céus/ Entrei!... ela me olhou branca... surpresa!/ Foi a última vez que vi Teresa/ E ela arquejando, murmurou-me: "adeus"!
} 
(os olhos nasceram e ficaram dez anos esperando que o resto do corpo nascesse)

Da terceira vez não vi mais nada

Os céus se misturaram com a terra

E o espírito de Deus voltou a se mover sobre a face das águas

Novamente, o exercício criativo de Bandeira assume um caráter de original, que ele próprio reconhece: "Num comentário, de humor muito sofisticado, dava o meu poema "Teresa" como tradução tão afastada do original, que a espíritos menos avisados pareceria criação" (BANDEIRA, 1966, p. 94). Ainda tendo Teresa como protagonista, a brincadeira poética de Bandeira se estende a um poema de Joaquim Manuel de Macedo ${ }^{116}$. Com a intenção de brincar com linguagem cafajeste, foi publicada também no jornal A Noite, em 1925, como sendo uma "tradução pra caçanje":

Teresa, se algum sujeito bancar o sentimental em cima de você

E te jurar uma paixão do tamanho de um bonde

Se ele chorar

Se ele se rasgar todo

Não acredita não Teresa

Se ele se ajoelhar

É lágrima de cine É tapeação

Mentira

CAI FORA.

Teresa é um nome recorrente na poesia de Bandeira e essa "tradução" joga tanto com a intertextualidade do poema Castro Alves, como com a intratextualidade de seus próprios poemas, pois ressurge em "Madrigal tão engraçadinho", Libertinagem (1930), estabelecendo um diálogo entre eles.

A irreverência de Bandeira é uma investida contra os modelos poéticos rígidos e o vocabulário erudito e, concomitantemente, uma sátira aos modernistas. Essas brincadeiras não foram totalmente inconsequentes e na avaliação de Bandeira estigmatizaram a poesia moderna:

Por essas e outras brincadeiras agora estamos pagando caro, porque o "espírito de piada", o "poema-piada" são tidos hoje por característica precípua do modernismo, como se toda a obra de Murilo, de Mário de Andrade, de Carlos Drummond de Andrade e outros, eu inclusive, não passasse de um chorrilho de piadas (BANDEIRA, 1966, p. 59).

\footnotetext{
${ }^{116}$ Mulher, irmã escuta-me: não ames/ Quando a teus pés um homem terno e curvo/ Jurar amor, chorar pranto de sangue/ Não creias não, mulher: ele te enganal As lágrimas são galas de mentiral Eo juramento manto de perfídia.
} 
Exageros à parte, a poética de Bandeira já era reconhecida em vida, tanto na poesia autoral quanto em tradução. Todavia a fortuna crítica da tradução em prosa é escassa. Uma breve menção a duas obras de literatura ligeira traduzidas por Bandeira acha-se no poema de Elisabeth Bishop, To Manuel Bandeira with a present:

\author{
Smiled on by Fame and Miss Brazil. \\ Is this the man to keep so still? \\ The gallant man who rendered in \\ more graceful language Elinor Glyn? \\ Gave lovely Latin things to utter \\ to Tarzan, who could barely mutter, \\ and polish Edgar Burrough's brute \\ Should such a man as this be mute?
}

Nesse poema, um "diálogo poético" 117 que ela manteve com Bandeira envolvendo troca de livros e de cartas-poemas, Bishop considera que Bandeira melhora o texto elogiando a "linguagem galante" com que Bandeira traduz o livro de Elinor Glyn, Tudo se paga (The price of things), da Biblioteca das Moças, e o refinamento do Tarzan em português em $O$ tesouro de Tarzan (Tarzan and jewels of Opar), de Burroughs, da Coleção Terramarear. Para seus contemporâneos, Bandeira desempenhava a tarefa de tradutor de prosa com "bom gosto, atenção para os menores detalhes, vestindo a obra de um aspecto digno, talvez inexistente no original" (BACIÚ, 1966, p. 86). Essa observação revela como o prestígio do poeta chancela a tradução, numa avaliação a priori, pois sugere o desconhecimento do texto fonte.

No período de 1930 a 1940 a maioria das traduções realizadas por Bandeira era de prosa e das dez obras publicadas, somente três não são de ficção: duas biografias (Minha cama não foi de rosas e A vida secreta de D'Annunzio) e um livro que poderia ser classificado como sendo de autoajuda ( $A$ educação da vontade). O restante é bastante representativo do gosto do público leitor da época: três romances de aventura, dois policiais e dois de ficção científica. Em todas as publicações o destaque do nome de Manuel Bandeira na capa, ou na folha de rosto, avaliza tanto as obras "sérias" como as de literatura de entretenimento.

Publicadas posteriormente, obras consideradas de maior valor literário contam com prefácios de nomes ilustres elogiando, até exageradamente, o tradutor. No livro do

\footnotetext{
${ }^{117}$ Cf. Flora SÜSSEKIND. "A geléia e o engenho: em torno da carta-poema de Elizabeth Bishop a Manuel Bandeira".
} 
filósofo francês Jacques Maritain, Reflexões sobre os Estados Unidos, Gustavo Corção (1959, p. 11) declara que "a tradução portuguesa teve a sorte de ser feita por MANUEL BANDEIRA", assim em letras maiúsculas para enfatizar a sua importância. A respeito da tradução da autobiografia de Clifford W. Beers, Um espírito que achou a si mesmo, Afrânio Peixoto também evoca o talento do poeta enquanto tradutor:

Em vernáculo, é traduzido por grande poeta, cuja sensibilidade bem mereceu este original, digno da pena de Manuel Bandeira. A mim me quis ele distinguir com a condecoração de pedir estas palavras. Nunca minha inteligência e minha sensibilidade se encontraram tão juntas, em minha pena. Uma obra prima, traduzida em linguagem por um poeta [...] (PEIXOTO, 1934, p. 11).

As editoras da década de 30 viram no romance de aventura, ao lado do romance policial, um mercado comercial promissor e o nome do tradutor também contribuiria para o sucesso de venda. De 1934 a 1940 são publicadas sete traduções de literatura ligeira, duas biografias e um livro de auto-ajuda realizadas por Bandeira:

\begin{tabular}{|c|l|l|}
\hline 1934 & O Tesouro de Tarzan & Edgar R. Burroughs \\
\hline & O Calendário & Edgar Wallace \\
\hline 1935 & Nômades do Norte & James Corwood \\
\hline 1936 & Aventuras Maravilhosas do Cap. Corcoran & Alfred Assolant \\
\hline 1936 & Minha Cama não Foi de Rosas & O.W. \\
\hline 1936 & Gengis Khan & Hans Dominck \\
\hline 1936 & A Educação do Caráter & Vignes Rouges \\
\hline 1937 & Mulher de Brio & Michael Arlen \\
\hline 1938 & O Túnel Transatlântico & Bernhard Kellerman \\
\hline 1939 & A Vida Secreta de D'Annunzio & Tom Antognini \\
\hline
\end{tabular}

Tabela 2: Relação das traduções realizadas por Bandeira entre 1930-1940 ${ }^{118}$

O prestígio de Bandeira era tal entre seus contemporâneos que a tradução desses livros considerados pela crítica literária como sendo de um gênero menor, ou "subgênero", era por eles supervalorizada:

Assim mesmo, Bandeira trabalhou, anos e anos, sem se aborrecer ou se cansar, realizando algumas vezes dezenas de excelentes traduções, mesmo quando se

118 A relação das traduções realizadas por Bandeira teve como fonte: WANDERLEY (op cit.). BANDEIRA. Itinerário de Pasárgada. COELHO, Eduardo dos Santos Coelho. Arqueologia da composição: Manuel Bandeira. Tese de doutoramento. Programa de pós-graduação em Letras Vernáculas. Universidade Federal do Rio de Janeiro. 2009; Fundação Casa Rui Barbosa, www.casaruibarbosa.gov.br. 
tratava de livros escolhidos pelo editor apenas por se tratar de um dos possíveis best sellers da temporada (BACIÚ, 1966, p. 86).

Stefan Baciú (1966, p. 86) não poupa elogios à tradução de Sonnets from the Portuguese ao que Bandeira, todavia, rebate:

Gostaria que fôsse verdade o louvor tão lisonjeiro de meu amigo Abgar. Mas devo confessar que sou bastante fundo no inglês. Fundo no sentido que a palavra tem na gíria. Tôdas aquelas soluções julgadas tão felizes pelo crítico, por mais cavadas ou sutis que pareçam, devem se ter processado no subconsciente, porque me saíram quase ao correr do lápis (BANDEIRA, 1966, p. 123).

Não obstante o volume de traduções realizadas por Bandeira, Wanderley (1988, p. 27), alega que tais obras "não constituem, em si mesmas, um corpus definidor de programa", pois diferentemente dos tradutores diletantes, aqueles que não tiram da tradução seu sustento, Bandeira sendo tradutor "contratado" não tinha grande poder de escolha.

Realmente, não se pode afirmar que Bandeira tenha desenvolvido uma teoria de tradução. O que se encontra são depoimentos onde o poeta reflete sobre a atividade partindo da sua práxis, levantando questões como a intraduzibilidade da poesia e a busca de equivalência. A afirmação de Bandeira, "só no chão da poesia piso com alguma segurança" (Bandeira, 1966, p. 109), revela a congenialidade entre o poeta e o tradutor de poesia. O texto fonte encontra eco no espírito criador: "Só traduzo bem os poemas que gostaria de ter feito, isto é, os que exprimem coisas que já estavam em mim, mas informuladas" (BANDEIRA, 1966, p. 123).

Stefan Baciú aponta para um movimento de influência recíproca entre a criação poética de Manuel Bandeira e os poemas por ele traduzidos, que revelam "bom gosto, atenção para os menores detalhes, vestindo a obra de um aspecto digno, talvez inexistente no original":

Nos Poemas Traduzidos não se deve atentar tão-somente para a seleção das peças, que demonstra uma vez mais o excepcional bom gosto de Bandeira, mas para o amor dedicado à arte de traduzir, porquanto, como o confessa, o poeta só se sente capaz de traduzir os versos que 'gostaria de ter feito'. (BACIÚ, 1966, p. 86).

Esse autor ainda ressalta a importância de Bandeira na divulgação de poetas desconhecidos do público por meio de antologias e traduções, os quais também viriam a influenciar a literatura moderna: "No mundo da poesia, Bandeira sempre andou nas regiões mais profundas, no que se refere à técnica de traduzir e, na vanguarda da 
vanguarda, para descobrir poetas novos e poetas importantes desconhecidos no Brasil" (p. 86).

Sérgio Milliet é outro crítico, que destaca a habilidade de Bandeira em recriar o poema em português num processo de quase autoria. A propósito da tradução de um poema de Cristina Rossetti afirma:

Se se colocar em frente desse texto o original inglês ter-se-á uma ideia precisa daquilo que eu insisto em denominar equivalência e que consiste não na tradução exata das palavras, mas na expressão do mesmo sentimento, e até das mesmas imagens, sob forma diferente (Apud BANDEIRA, 1966, p. 123).

Jorge Wanderley (1988), por sua vez, avalia que essas traduções apresentam um "vezo bandeiriano", que é fruto de "solução mais pessoal que fiel" ao adicionar elementos que o original não contém, conseguindo muitas vezes "tornar [a tradução] melhor que o original". Ainda para esse autor, tais “enxertias" são marcas típicas da poesia de Bandeira: musicalidade, inversões, toque de arcaísmo, palavras recorrentes de seu próprio vocabulário, seu próprio universo imagístico.

Para Paes (1990, p. 61), a operação tradutória de Bandeira consiste na "criação de um símile do poema original capaz de produzir, nos leitores da língua alvo, efeitos semelhantes aos produzidos pelo dito poema nos leitores da língua fonte". Tanto assim, que algumas de suas traduções foram publicadas entre versos de sua autoria e passariam por criação original, como dois poemas de Christina Rossetti, em Estrela da manhãa, e o de Elisabeth Barrett Browning, em Libertinagem. Dentre essas traduções "geralmente reconhecidas como de maior interesse do que os originais" (Milton, 1993, p. 170) encontra-se também um poema de Pierre de Ronsard, poeta renascentista francês. Na primeira edição comercial, de 1948, de Poemas traduzidos, um poema de Ronsard aparece com o título de "Soneto de Ronsard" e nas edições subsequentes como "Paráfrase de Ronsard". Em ambos os casos, Bandeira responsabiliza-se pelo texto ao publicá-lo em Cinza das horas, juntamente com outros de sua autoria. A mudança do título, de "Soneto de Ronsard" para "Paráfrase de Ronsard", assim como a inclusão entre criações do próprio Bandeira, evidencia sua concepção do processo de tradução poética como uma forma de apropriação e não de imitação. Para Milton (1993, p. 170), as traduções de Bandeira "são distintivas por seu frequente distanciamento do textofonte, dando uma impressão geral deste em vez de uma tradução palavra por palavra". 
Ao confrontarmos o poema de Ronsard e a tradução de Bandeira, verificamos que há correspondência completa na forma do soneto, mas não a correpondência verso a verso do francês com o português.

\section{Pierre de Ronsard}

Je vous envoie un bouquet que ma main Vient de trier de ces fleurs épanies Qui ne les ê̂t à ce vêpre cueillies

Chutes à terre elles fussent demain.

Cela vous soit un exemple certain Que vos beautés, bien qu'elles soient fleuries, En peu de temps cherront toutes flétries Et comme fleurs périront tout soudain.

Le temps s'en va, le temps s'en va, ma Dame, Las! le temps, non, mais nous nous en allons Et tôt serons étendus sous la lame.

Et les amours desquelles nous parlons, Quand seron morts, ne sera plus mouvelle; Pour ce, aimez-moi cependant qu'êtes belle.

\section{Manuel Bandeira}

Foi para vós que ontem colhi, senhora, Este ramo de flores que ora envio. Não o houvesse colhido, e o vento e o frio Tê-las-iam crestado antes da aurora.

Meditai nesse exemplo, que se agora Não sei mais do que o vosso outro macio Rosto nem boca de melhor feitio, A tudo a idade altera sem demora.

Senhora, o tempo foge... o tempo foge...

Um dia morreremos, e amanhã

Já não seremos o que somos hoje...

Porque é que o vosso coração hesita? O tempo foge... A vida é breve e é vã... Por isso...amai-me... enquanto sois bonita ${ }^{119}$

Bandeira ora inverte posições: o $1^{\circ}$ verso de Ronsard corresponde ao $2^{\circ}$ verso de Bandeira; ora insere acréscimos, como os versos da segunda estrófe: Não sei mais do que o vosso outro macio/ Rosto nem boca de melhor feitio; ora substitui versos inspirados em outro poema do próprio Ronsard, ("Mignonne allons voir si la rose..."), abaixo cotejados:

Tê-las-iam crestado antes da aurora A tudo a idade altera sem demora Por que é que o vosso coração hesita ne dure que du matin jusqu'au soir; La veillesse fera tenir votre beauté. Donc si vous me croyez mignonne.

Por conseguinte, o trabalho de Bandeira como tradutor, por ser tributário da atividade primeira não é secundário, pois é também criativo. Observando uma interdependência produtiva entre o fazer poético e o traduzir, Paes (1990, p. 85) conclui que a oficina de tradutor de poesia não difere substancialmente da oficina de poeta e que

\footnotetext{
${ }^{119}$ A pontuação deste verso é a da edição de Poemas Traduzidos de 1948. Nas edições posteriores (e em Estrela da vida inteira) a pontuação do verso é: "Por isso, amai-me... enquanto sois bonita".
} 
ambas estariam alicerçadas na "intuição criadora" e na "máquina secreta da subconsciência". A essa reflexão podemos acrescentar a de Leonardo Fróes, que prefaciou o opúsculo Alguns poemas traduzidos (2007, p. 10): "O poeta traduz, tocado ao ler, para se apropriar do que traz, naquele instante, alguma nota de conhecimento afetivo a seu próprio respeito". Donde se conclui que a congenialidade com a obra desempenha papel primordial para Bandeira na tradução de poesia.

Bandeira sempre foi e tem sido louvado como poeta, contudo, não é suficientemente lembrado pela atividade de tradutor, sendo que pouquíssima importância é dada às suas traduções de prosa. Mesmo que Bosi (2002, p. 361) julgue Bandeira como um "homem de métier, capaz de compor em todos os ritmos e de traduzir com igual maestria Shakespeare e Holderlin, Rilke e García Lorca”, a obra poética de Bandeira é de tal magnitude que ofusca todas as suas outras atividades. A tradução de prosa realizada por Bandeira, quer por necessidade econômica, por gosto ou por prestígio do ofício, pode ser de grande valia para a compreensão de como a tradução está imbricada na rede de manifestações culturais e ideológicas de um tempo histórico, mesmo que as considerações sobre a atividade tradutória de Manuel Bandeira evidenciem o lugar do tradutor à sombra do poeta.

\subsubsection{Monteiro Lobato: factótum das letras}

"Sujeito múltiplo" (LAJOLO, 2014), Monteiro Lobato foi figura pioneira em diversas áreas. De personalidade contestadora ele viveu o modernismo sem ser modernista, defendeu a manutenção do petróleo brasileiro, pregou maior liberdade da língua literária, criticou as práticas de agricultura de seu tempo. Por suas opiniões contundentes foi preso pelo governo Vargas, em 1941, e rejeitado por alguns críticos literários e por alguns de seus pares escritores. As críticas a Lobato se estendem até mesmo depois da sua morte, como na recente acusação de racismo e de crueldade contra os animais nos livros do Sítio do Pica-pau Amarelo:

Até hoje, ele e sua obra pagam o preço alto de um discurso móvel, dinâmico, muitas vezes incômodo. Assumindo posições extremamente pessoais e destemidas, Monteiro Lobato foi sempre polêmico ao longo dos 43 anos que separam sua primeira publicação de grande impacto junto ao público (o artigo "Velha praga" estampado em $O$ Estado de São Paulo, em 12 de novembro de 1914) do igualmente impactante Zé Brasil, lançado em 1947, um ano antes da morte do escritor (LAJOLO, 2014, p. 14). 
Homem das letras, Lobato atua como escritor, editor e tradutor expressando ideias inovadoras de empreendorismo nacional e estão tão interligadas que é difícil de serem dissociadas. Koshiyama (1982, p. 187) observa que "a ação de Monteiro Lobato consistiu numa coerente defesa de interesses do setor editorial brasileiro enquanto empresa capitalista, ação concretizada na condição de escritor, tradutor e empresário (editor e gráfico)". O pragmatismo definiu suas estratégias editoriais e tradutórias na sua preocupação de atingir o maior número de leitores possíveis.

Embora entre 1930 e 1940 Lobato não fosse mais empresário e não tivesse mais o controle do sistema de produção livreira, mantinha-se como escritor e tradutor inserido na economia de mercado, pois "na medida em que satisfazia os leitores compradores com seus textos, atendia aos interesses dos editores e livreiros com lucros provenientes da circulação de mercadorias - os livros - alguns com inúmeras edições e traduções" (KOSHIYAMA, 1982, p. 194).

Lobato começou a traduzir em 1909, quando morava numa pequena e pacata cidade interioriana, ao tomar uma assinatura do Weekly Times, de Londres, que segundo ele, era "para neutralizar esta Areias sem apito" (LOBATO, 1957a, p. 225). No ano seguinte começa a traduzir para o Estado de São Paulo quando encontra "coisas interessantes" na publicação americana semanal recebendo $10 \$ 000$ pelo trabalho. Em carta a Rangel revela como a atividade lhe parece simples sinecura: "Acho estranho isto de ganhar um dinheiro qualquer com o que nos sai da cabeça. Vender pensamentos próprios ou alheios... Mas não tolero escrever por obrigação. Traduzo quando quero" (LOBATO, 1957a, p. 250). Tal afirmação parece paradoxal para quem, em 1920, iria adotar uma visão comercial com respeito à literatura. Escreve Lobato a Rangel: "Faço livros e vendo-os porque ha mercado para a mercadoria; exatamente o negocio do que faz vassouras e vende-as, do que faz chouriços e vende-os" (LOBATO, 1957b, p. 211).

Deve-se levar em conta o fato de que eram dois momentos diferentes na vida de Lobato: o de Promotor Público da Comarca de Areias e o de empresário no ramo editorial, atividade iniciada em 1918 na Revista do Brasil, "órgão de prestígio entre os literatos e que serviria de veículo de divulgação para uma editora de livros" (KOSHIYAMA, 1982, p. 68). Interessante notar que não obstante já tendo a experiência positiva com Saci e Urupês, Lobato sobrepõe o empresário ao escritor na mesma carta a Rangel: "não sou literato, não pretendo ser, não aspiro a louros acadêmicos, glórias, bobagens". Todavia, o sucesso de venda de Urupês já seria um atestado de 
reconhecimento literário. Edgar Cavalheiro (1955, p. 285) assim explica essa manifestação de "modéstia":

Êsse desdém pelo "profissional", pelo homem de letras, só pode ser entendido se pensarmos que tais desabafos surgem quando o homem de negócios está até o pescoço, metido na engrenagem do comércio e da indústria. Não serve impunemente a Deus e a Mamon, lembra Agripino Grieco. O desprêzo não esconderia também a incapacidade criadora?

No entanto, não fora o dinheiro que ganhou com a literatura, Lobato não teria capital suficiente para tornar-se empresário, que acabou por perder tudo posteriormente no comércio e nos investimentos. Somente em 1944, Lobato voltaria ao mercado editorial ao juntar-se a Caio Prado Jr., Leandro Dupré e Artur Neves, fundadores da Editora Brasiliense. O convite para participar da sociedade não foi sem motivação: "Seu nome e suas obras seriam decisivos para a consolidação da nova empresa" (PAIXÃO, 1997, p.52).

Lobato foi tradutor de um número considerável de todos os gêneros de literatura em prosa. Entre 1930 e 1940 Lobato realiza trinta e cinco traduções (elencadas na tabela a seguir) e duas revisões: A luta pelo petróleo, de Essad Bey, com tradução de Charlie W. Frankie (1935), e Os náufragos de Borneo, de Mayne Reid (1933). Também consta que Lobato adaptou, em 1937, Viagens de Gulliver ao País dos Homenzinhos de Um Palmo de Altura, de Jonathan Swift.

\begin{tabular}{|l|l|l|}
\hline 1932 & Contos de Andersen & Hans C. Andersen \\
\hline 1933 & Alice no País do Espelho & Lewis Carroll \\
\hline & Mowgli, O Menino-Lobo & Kipling, Rudyard \\
\hline & Caninos Brancos & Jack London \\
\hline & Os Negreiros da Jamaica & Mayne Reid \\
\hline 1934 & O Doutor Negro & Conan Doyle \\
\hline & Jacala & Rudyard Kipling \\
\hline & O Lobo do Mar & Jack London \\
\hline & Aventuras de Huck & Mark Twain \\
\hline & Aventuras de Tom Sayer & Mark Twain \\
\hline & O Querido Inimigo & Jean Webster \\
\hline & O Homem Invisível & Herbert George Wells \\
\hline & Patty & Jean Webster \\
\hline 1935 & O Pequeno César & William Riley Burnett \\
\hline & Tarzan, o Terrível & Edgard Rice Burroughs \\
\hline & Cleópatra & E. Barrington \\
\hline & O Grito da Selva & Jack London \\
\hline & Scarface, o Tzar dos Gangsters & Armitrage Trail \\
\hline
\end{tabular}




\begin{tabular}{|l|l|l|}
\hline & O Crime do Casino & S.S. Van Dine \\
\hline & A Ilha das Almas Selvagens & Herbert George Wells \\
\hline 1936 & Tarzan no Centro da Terra & Edgard Rice Burroughs \\
\hline & Alice no País das Maravilhas & Lewis Carroll \\
\hline & A ceia dos acusados & Dashiell Hammett \\
\hline & O Caso Garden & S. S. Van Dine \\
\hline & Filosofia da Vida & Will Durant \\
\hline 1938 & Novos Contos de Grimm & Irmãos Grimm \\
\hline & Rumo às Estrelas & H. Dennis Bradley \\
\hline & Os Grandes Pensadores & Will Durant \\
\hline & A Evolução da Física & A. Einstein \& L. Infield \\
\hline & Raymond & Oliver Lodge \\
\hline & Contos de Fada & Charles Perrault \\
\hline 1940 & $\begin{array}{l}\text { As Máquinas da Democracia: As invenções e suas } \\
\text { Influências Sociais nos Estados Unidos }\end{array}$ & Roger Burlingame \\
\hline & Meu Filho, Meu Filho! & Howard Spring \\
\hline & A História da Bíblia & Hendrik Willem Van Loon \\
\hline & História do Futuro & Herbert George Wells \\
\hline
\end{tabular}

Tabela 3: Relação das traduções realizadas por Lobato entre 1930-1940 ${ }^{120}$

Ainda nessa década, Lobato traduziu duas obras "a quatro mãos": uma com Lígia Junqueira Smith, Rebecca, de Daphne Du Maurier, e outra com Godofredo Rangel, História da Filosofia, de Will Durant. Em 1934, Lobato sugere a parceria ao amigo:

Dividamos ao meio a Story of Philosophy do Will Durant e assinemos com iniciais os capítulos que traduzirmos. Juntos sempre, até na história da filosofia... Minha idéia é fazer trabalho perfeito. O Otales não tem muita pressa. Durant merece todo carinho, e nós temos responsabilidades (LOBATO, 1957b, p. 326).

Ao que parece, outras obras não eram tão merecedoras de tanta consideração, como se pode observar nesta outra carta também a Rangel: "Sabe que concentrei um Robinson? Otales encomendou-me e fi-lo em cinco dias - um recorde: 183 páginas em cinco dias, inclusive em domingo cheio de visitas e partidas de xadrez com o Benzinho" (LOBATO, 1957b, p. 323). A rapidez em detrimento da qualidade refletia sua identificação com os interesses editoriais. As traduções de obras anglófonas vendiam bem e a literatura de entretenimento parecia não exigir deferência: "Na verdade,

\footnotetext{
${ }^{120}$ Fonte: http://www.dicionariodetradutores.ufsc.br/pt/MonteiroLobato.htm Acesso 12/10/2013.
} 
considerações de ordem qualitativa tornavam-se secundárias, mesmo para intelectuais, quando preocupados com as vantagens financeiras da edição de uma obra" (KOSHIYAMA, 1982, p. 155).

Lobato retoma suas atividades de escritor e tradutor no início da década de 1930, após regressar dos Estados Unidos. Ele já havia perdido suas ações da Companhia Editora Nacional e até os direitos autorais de seus livros, mas foi para essa casa que Lobato mais traduziu. Segundo Cavalheiro (1955, p. 763), das oitenta e sete obras traduzidas por Lobato apenas cinco não eram publicações da Companhia Editora Nacional. A maioria das traduções se deu na década de 1940 (53\%), seguida pela década de 1930 (42\%) e somente 5\% das traduções foram realizadas na década de 1920, sendo que $67 \%$ correspondem a traduções do inglês como língua-fonte, conforme estatísticas de Denise Resende Mendes (2002, p. 40). Aliás, com o passar do tempo, Lobato cada vez mais se debruça sobre textos em inglês: "E tenho lido exclusivamente em inglês. $\mathrm{O}$ francês anda a me engulhar todas as tripas. [...] A literatura inglesa é muito mais arejada, variada, mais cheia de horizontes, arvores e bichos" (LOBATO, 1957a, p. 226), escreve a Rangel.

Necessitando dinheiro devido à falência e às perdas com os investimentos na bolsa de Nova York, Lobato dedica-se à tradução. Cavalheiro (1955, p. 533) relata que ao regressar dos Estados Unidos Lobato faria da tradução o principal meio de vida, quando "atira-se ao trabalho com todo o entusiasmo". O próprio Lobato confirma:

Tenho empregado as manhãs a traduzir, e num galope. Imagine só a batelada de janeiro até hoje: Grimm, Anderson, Perrault, Contos de Conan Doyle, O homem invisivel de Wells e Pollyana moça, O livro da jungle. E ainda fiz Emília no país da gramática. Tudo isso sem faltar ao meu trabalho diário na Cia. Petróleos do Brasil" (LOBATO, 1957b, p. 327).

Tal presteza, todavia, se por um lado poderia agradar aos editores, por outro recebia críticas, conforme aponta Cavalheiro (1955, p. 533): "Diante da sua espantosa produção, alguns corvejadores de escândalo lançaram de público dúvidas sobre a autenticidade da autoria de muitos volumes que correm sob a sua responsabilidade". Lobato, disciplinado e metódico nesse trabalho, sentava-se à máquina de escrever "logo que chegava o leiteiro", só parando na hora do almoço:

O trabalho servia-lhe não só de ganha-pão, mas também como válvula de escape às suas angústias. Vinte páginas de um Roger Burlingame qualquer por dia é tarefa pesada, mas Lobato precisa esquecer o filho em agonia (CAVALHEIRO, 1955 p. 536). 
Com certeza, o serviço de tradutor, além de lhe prover remuneração indispensável, servia-lhe como distração, para desviar-lhe a atenção dos problemas e preocupações, que não foram poucas: "Continuo traduzindo. A tradução é a minha pinga. Traduzo como o bebedo bebe: para esquecer, para atordoar" (LOBATO, 1957b, p. 334). Muitos foram os dissabores: em 1930 adoece seu filho Edgar, (que viria a falecer em 1943), em 1938 morre o outro filho, Guilherme e após muitas desavenças com o governo de Getúlio Vargas, é preso em 1941. Lobato passa os dias trabalhando em traduções, conforme atesta carta à mulher distante, que vela o filho doente:

Domingo último bati um recorde. Não saí de casa e ninguém veio me amolar; resultado: fiz 67 páginas da minha tradução. Parei porque o dedo ficou dormente. Ontem entreguei o livro. Trezentas páginas em cinco dias! Foi o recorde dos recordes. Mas sòzinho como estou, o trabalho não tem remédio senão render (Apud, CAVALHEIRO, p. 535).

Se por um lado, as traduções em grande escala suscitavam dúvidas quanto à autoria - acusação das quais ele sempre se defendeu dizendo-se "visceralmente honesto" - por outro, eram criticadas pela qualidade, não obstante o empenho confesso do autor "de dar á bola em certos trechos de difícil tradução", mesmo que considerasse que a média do público leitor não era merecedor de tal empenho (LOBATO, 1957b, p. 328). Pela sua diligência, Lobato é incumbido, principalmente por Octalles Marcondes Ferreira, também de revisões e de retraduções de várias obras, como Kim, de Kipling, e For whom the bell tolls, de Hemingway, ambos com uma tradução anterior realizada por Agripino Grieco. Lobato depreciou o trabalho de Grieco apontando em carta a Rangel o que ele chama ironicamente de "pérolas do Agripino" (LOBATO, 1955b, p. 334). Parecia que Lobato queria dar o troco ao crítico literário que, apesar de considerar Lobato um "ficcionista robusto e novo" (CAVALHEIRO, 1955, p. 217), desaprovou-o como tradutor apontando diversos deslizes na tradução de História da literatura mundial, de John Macy (Idem, p. 536).

Agenor Soares de Moura, que manteve de 1944-1946 uma coluna sobre tradução no Diário de Notícias, com o titulo "À margem das traduções", (artigos posteriormente reunidos em livro por Ivo Barroso) tinha em Lobato um de seus alvos mais constantes. Moura, que considerava as traduções de uma perspectiva linguística, a partir dos conceitos de equivalência e fidelidade, não aceita as estratégias tradutórias "libérrimas" de Lobato. Escreve o crítico: "O eminente tradutor pula frequentemente frases, maiores ou menores, do original. Em compensação, enxerta de vez em quando coisas alheias ao 
texto" (MOURA, 2003, p. 71). Em outro artigo, sobre a tradução de $O$ homem invisível, de H.G. Wells, comenta: "um capítulo, apanhava-lhe o conteúdo e depois o exprimia, com maior ou menor exação, o assunto do mesmo. Adaptações destas, quase paráfrases" (Idem, p. 21). O que Moura condena em Lobato é exatamente a visão deste sobre o seu conceito de tradução: "A tradução tem que ser um transplante. O tradutor necessita compreender a fundo a obra e o autor, e reescrevê-la em português como quem ouve uma história e depois a conta com palavras suas" (LOBATO, 1957c, p. 127).

Trata-se de uma concepção bastante ousada em uma época em que se valorizava a fidelidade e a equivalência na tradução. Para entender a postura de Lobato deve-se levar em conta que sua preocupação de tradutor, também em certa medida a de autor, é sempre o público. Em muitos momentos Lobato frisa a necessidade de adequar a linguagem para o leitor brasileiro e ao achar um texto "pedante e requintado" ele não hesita em "raspar dele a literatura" e "tirar tudo quanto é empaste" (LOBATO, 1955b, p. 340).

Por uma linguagem mais brasileira a fim de facilitar o acesso do leitor à obra, Lobato aconselha Rangel: "Os contos de Shakespeare vão para que escolhas alguns dos mais interessantes e os traduzas em linguagem bem singela [...] Estilo água do pote, heim? E ficas com liberdade de melhorar o original onde entenderes" (LOBATO, 1955b, p. 275). Também com relação ao D. Quixote para crianças orienta que seja "mais correntio e mais em língua da terra" (p. 276). Em diversas ocasiões lembra o amigo para que "não perca de vista os leitores que vai ter" (LOBATO, 1957b, p. 280), embora Lobato não os tivesse em alta conta e afirmava ser um público "boeiro que engole qualquer coisa" (p. 328).

Monteiro Lobato, coerente com sua posição mercadológica, considerava que os êxitos comerciais de livros não atestavam, necessariamente, valor literário. Em agosto de 1918, ele dizia que as obras preferidas pelo público não são as melhores, as mais artísticas e chega mesmo a admitir que o bem sucedido Urupês nada mais era do que peças arrumadas para produzir efeitos cênicos ou sentimentais - "coisas de 'curioso' da roça, nada mais". E perguntava: - "Por que se reedita então? - Porque se vende. Já que o público é besta, toca explorar o público" (LOBATO, 1957b, p. 182). Monteiro Lobato, embora reprovasse o gosto do leitor, tratava de preencher essa solicitação do mercado, num "comportamento perfeitamente coerente com a lógica do capital" (KOSHIYAMA, 1982, p. 70). 
Partindo das afirmações de Lobato sobre como, o quê e para quem traduzir, alguns estudos relacionam as estratégias tradutórias de Lobato a conceitos desenvolvidos no âmbito dos Estudos da Tradução. A fluência buscada por Lobato nas traduções remete aos conceitos de domesticação como preconizados por Lawrence Venuti ${ }^{121}$; a liberdade com que ele manipulava e interferia no texto fonte suscita discussões sobre a conceituação de tradução e adaptação; a ideia de "remodelar" (LOBATO, 1957b, p. 327) o texto em outra língua o aproxima de uma prática antropofágica de traduzir e, por fim, ao utilizar a cultura estrangeira como forma de crítica às questões nacionais revela objetivos políticos e ideológicos. No entanto, tais recortes do pensamento de Lobato podem resultar em opiniões reducionistas e passíveis de serem contestadas em alguns aspectos.

Embora a preocupação de Lobato com a fluência do texto possa ser considerada domesticação, essa estratégia resulta na "invisibilidade" do tradutor, pois tal estratégia daria a impressão de que a tradução não é tradução, mas sim o "original", refletindo a personalidade e/ou a intenção do autor estrangeiro (VENUTI, 2002, p. 1). Não parece ser o que acontece no caso de Lobato, que intervinha no texto a seu bel prazer, marcando claramente sua presença discursiva. Por exemplo, na tradução de Pollyanna, conforme observa Katia Santos (2010, p. 192), nota-se por quase toda a fala da protagonista o "estilo emiliano de ser e pensar" (uma referência à boneca Emília personagem do Sítio do Pica-pau Amarelo, famosa por sua verborragia). E completa "Ao ler a tradução [Pollyanna] de Lobato tem-se a impressão de ler uma obra regional, as suas próprias obras: Memórias da Emília, ou mesmo Emília no país da gramática".

Lobato não "desaparece" no texto traduzido e no caso de intervenções radicais como em Peter Pan e Viagens de Gulliver, é reconhecido como autor. Também a ênfase dada ao nome de Lobato na capa das traduções estabelece uma relação de confiança junto ao leitor, pelo fato de ele ser um escritor conhecido:

A figura do escritor Lobato, cujo nome é apresentado na capa da tradução [de Kim], confere à mesma uma sustentação discursiva que, mesmo em face das passagens mais polêmicas da tradução, conduz o leitor à "certeza" de estar lendo uma obra traduzida pela pena de um escritor consagrado, cujas particularidades estilísticas poderiam, quem sabe, ter direcionado os caminhos da tradução que ele ou ela pretende ler. (AMORIM, 2005, p. 27)

\footnotetext{
${ }^{121}$ Cf. Lawrence VENUTI. Escândalos da tradução. 2002.
} 
Monteiro Lobato não se limita à operação de transposição linguística e edita o texto com omissões e acréscimos. Tal conjunto de operações evidencia o seu caráter autoral e resulta em um texto que passa a ser considerado como adaptação. A aplicação do conceito de adaptação à prática tradutória de Lobato se baseia no "alto grau de intervenção" praticado por ele (MARTINEZ, 2008). John Milton (2003, p. 115), por sua vez, analisa esse procedimento como sendo uma maneira de inserir suas ideias políticas através de comparações entre o país do texto fonte e os "males" do Brasil e "tanto Dom Quixote quanto Peter Pan podem ser vistos como figuras anárquicas, que se rebelam contra o que a sociedade espera deles". Essa perspectiva ideológica talvez possa ser aplicada com relação a essas duas obras, entretanto, trata-se de amostra muito reduzida em um espectro de dezenas de títulos.

É difícil categorizar a prática tradutória de Lobato. Embora adaptação, paráfrase, paródia, estilização e apropriação também sejam modos de reescrituras, não há um consenso com relação à conceituação teórica dessas transposições textuais, que dependem muito de fatores temporais, espaciais e sociais. Consequentemente, as traduções de Lobato devem ser consideradas em relação ao contexto e à tradição vigente na época.

Por fim, em diversos momentos, Lobato transmite a ideia da importância da tradução como atividade de troca cultural de grande impacto no Brasil, "uma vez que novos temas, personagens e ideologias estrangeiras perpassaram suas traduções, representando uma renovação do contexto literário nacional" (CAMPOS; OLIVEIRA, 2009, p. 72). O processo de Lobato de trazer para a cultura nacional a literatura estrangeira, sem que, contudo, haja uma substituição desta por aquela, leva Adriana Vieira (2001, p. 153) considerar Peter Pan, História do mundo para crianças e D. Quixote das crianças, não somente como sendo adaptações, mas também apropriações, numa prática antropofágica que se aproxima à dos irmãos Augusto e Haroldo de Campos. Em consonância com Vieira, Sabrina Lopes Martinez (2008, p. 3), avalia que no projeto de popularização da literatura, Lobato "assumia a postura antropofágica dos modernistas em relação à sua estratégia tradutória: a de apropriar-se do original estrangeiro e adaptá-lo à realidade e às necessidades do público brasileiro".

Ainda para Adriana Vieira (2001, p. 152), a ideia de tradução de Lobato apresenta similaridades com a noção da "nutrição" e John Milton (2004, p. 225) entende 
que nesse processo são inseridas "marcas com características brasileiras". Vera Lúcia Ramos, discorda na sua análise de Huckleberry Finn:

Lobato distancia-se de Twain, não apenas por não empregar a linguagem dialetal em seu texto, ou ainda por ampliar ou cortar algumas partes, mas principalmente quanto às mudanças nas características de Jim. [...] A voz das três personagens [Jim, Tom e Huck], pelo uso do português culto é calada pela estratégia de 'melhorar o texto' quando for necessário. [...] não acreditamos haver em Huck, Tom e Jim qualquer marca de brasilidade, pois caso houvesse, talvez, Jim pudesse ter sido representado de forma mais positiva (RAMOS, 2008, p. 123).

Se a metáfora da antropofagia é controversa no tocante à prática tradutória dos irmãos Campos ${ }^{122}$, relacionar Lobato à antropofagia é problemático em termos de objetivo e de objeto da tradução: Lobato traduz literatura de entretenimento em um contexto comercial, com foco no leitor; os irmãos Campos buscam renovação estética por meio da tradução de textos mais eruditos. Giovana Cordeiro Campos e Maria Clara Castellões de Oliveira reforçam essa opinião:

Seria uma precipitação aproximar a prática tradutória de Lobato e a de Campos, cuja antropofagia tradutória representava a possibilidade de ampliação da língua da tradução por meio da língua do original. Todavia, cabe ressaltar que o projeto tradutório de Lobato, ainda que não envolvesse uma renovação linguística, teve grande impacto cultural no Brasil, uma vez que novos temas, personagens e ideologias estrangeiras perpassaram suas traduções, representando uma renovação do contexto literário nacional (CAMPOS; OLIVEIRA, 2006, p. 72).

Além de as duas práticas partirem de pressupostos diferentes, a comparação não se sustenta também porque Lobato não buscou a renovação da linguagem poética como os irmãos Campos, mesmo sendo crítico ferrenho da tradução literal "que trai e mata a obra traduzida". Quando Lobato fala em "remodelar uma obra de arte em outra língua" (1957b, p. 327), ele provavelmente está se referindo a adequar o conteúdo à forma da língua alvo tendo em mente um público leitor consumidor de cultura de massa, que se achava em formação, principalmente na década de 1930:

O bom tradutor deve dizer exatamente a mesma coisa que o autor diz, mas dentro da sua língua de tradutor, dentro da sua forma literária de tradutor; só assim estará realmente traduzindo o que importa: a ideia, o pensamento do autor. Quem procura traduzir a forma do autor não faz tradução - faz uma horrível coisa chamada transliteração, e torna-se ininteligível (LOBATO, 1957c, p. 118).

Vale notar que as análises acima elencadas mostram atitudes pontuais de Lobato com relação à tradução, tendo como corpus a tradução de uma ou duas obras, as quais

\footnotetext{
${ }^{122}$ Cf. Célia PRADO. Pós-colonialismo e o contexto brasileiro: Haroldo de Campos, um tradutor póscolonial? Dissertação de mestrado. FFLCH-USP 2009.
} 
se acham inseridas em contexto histórico-cultural específico. Compreende-se a dificuldade de abarcar toda a reflexão de Monteiro Lobato sobre tradução, publicação e recepção e aplicar um só conceito a ela, que foi desenvolvida a partir de seu primeiro trabalho como tradutor, em 1909, e percorre várias décadas até sua última tradução em 1945, segundo carta a Godofredo Rangel: "Essa tradução é a ultima que faço, e fi-la porque já tinha traduzido os primeiros volumes. Uf!... Chega. Mas vou ter saudades" (LOBATO, 1957b, p. 365).

Sua atividade de tradutor abrangeu um momento de grande complexidade, que oscilava entre a manutenção dos valores do passado e o anseio por transformação no campo político, social e cultural.

\subsubsection{Godofredo Rangel: o amigo escrito}

Mineiro de Três Corações, José Godofredo de Moura Rangel (1894-1951) veio para São Paulo em 1902 iniciar os estudos na Faculdade de Direito. Na capital paulista conhece o poeta Ricardo Gonçalves que o introduz na turma do "Cenáculo", da qual fazia parte também Monteiro Lobato. A literatura unia o grupo e era o tema dominante nos encontros: "Tinham como diziam, o carnegão literário; eram vítimas da mesma doença" (ATHANÁZIO, 1977, p. 23).

Em 1904 Godofredo Rangel parte para o interior, primeiramente para Campinas e depois para muitas cidades de Minas Gerais, pois como bacharel em Direito assume cargos de promotor e juiz, mas sempre lecionando português e inglês. Rangel inicia sua carreira de escritor colaborando com contos e crônicas em jornais e revistas, publicando capítulos do seu primeiro romance, Vida ociosa, em O Estado de São Paulo, em 1917.

Diferentemente dos dois outros tradutores, aqui estudados, Rangel, apesar de ter sido membro da Academia Mineira de Letras (eleito em 1939), não teve destaque como escritor, não obstante a edição de lançamento de Vida ociosa ter se esgotado em pouco tempo. A sua "existência no mundo literário" se deve a Monteiro Lobato que reuniu em livro as cartas que escreveu a Rangel o companheiro dos tempos do "Minarete" 123 durante quarenta anos. Rangel, apesar de insistir na publicação das cartas de Lobato, proibiu a divulgação de suas prórprias, tornando-se o interlocutor epistolar "mudo".

Pode-se dizer que a correspondência unilateral, que registra apenas o eco de Rangel, é fruto do desejo deste, somado ao espírito empreendedor de Lobato que,

\footnotetext{
${ }^{123}$ Casa onde morava Rangel e ponto de encontro para o grupo que se intitulou "Cenáculo".
} 
em 1944, organizou a edição, datilografando as cartas, apondo algumas notas (apenas uma é de Rangel) e a dedicatória. O mérito maior pela edição talvez caiba a Rangel, guardião das cartas, pela insistência com que, ao longo do tempo, venceu a relutância de seu correspondente, persuadindo-o a publicá-las (CASSAL, 2002, p. 25).

Apesar da insistência de Lobato, Rangel impediu que se publicassem suas cartas mesmo após sua morte, conforme relata Cavalheiro (1955, p.138): "o mineiro, arredio e tímido, não se deixou envolver pelos argumentos do amigo, e segundo nos informa seu filho, Dr. Nelo Rangel, pediu que não publicasse as cartas nem mesmo após sua morte". Enéas Athanázio (1977, p. 45) acrescenta: "o único motivo que Rangel apresentava para não fazê-lo era o de que suas cartas não possuem nenhum interesse especial, e sim apenas o de provocar as excelentes respostas de Lobato". Assim, a publicação de $A$ barca de Gleyre não é a coletânea da correspondência entre Lobato e Rangel, mas de Lobato para Rangel. Nos quarenta anos desse relacionamento epistolar os dois pouco se encontraram. Dizia Lobato: "Não somos amigos falados, somos amigos escritos" ${ }^{124}$.

A falta das cartas do outro lado faz com que o leitor exercite sua imaginação para conhecer um Rangel através dos comentários do amigo famoso e é praticamente impossível falar de Rangel sem citar Lobato. Deve-se a essa correspondência o pouco que se sabe da produção literária e da vida do amigo mineiro e a duas pequenas biografias escritas por Enéas Athanázio, Godofredo Rangel e $O$ amigo escrito:

Não o registram, ou fazem de modo impreciso, as enciclopédias e os dicionários de literatura, histórias e ensaios de crítica. Alguns lhe dedicam umas poucas linhas, mas enfatizando em demasia a correspondência com Monteiro Lobato, em detrimento de sua própria obra, relegada a segundo plano (ATHANÁZIO, 1977, p. $11)$.

Dentre seus contemporâneos, Manuel Bandeira é um dos poucos a citá-lo em Noções de história da literatura (1954, p. 116), classificando-o de escritor "realista" da ficção regionalista pelo seu romance Vida ociosa. Qualificação contrariada por seu contemporâneo Hilário Tácito ${ }^{125}$ (2000 xxi) prefaciador dessa obra: "O estilo deste escritor, as descrições, a linguagem, tudo se apresenta com tanta ordem, com tanta clareza e honestidade de expressão, que não há descobrir aquele realismo de inventário, como o qualificou Machado de Assis". Também sua atuação como tradutor é lembrada

\footnotetext{
124 No prefácio do livro de contos, Os humildes, de Rangel. Cf. RAMOS, Maria Luiza. Reflexões sobre os estudos literários. Revista de estudos de literatura. vol 2. Belo Horizonte: UFMG, out 1994, p 9-50. ${ }^{125}$ Pseudônimo de Josá Maria de Toledo Malta.
} 
por Bandeira de maneira suscinta, por ocasião do lançamento de $O$ clube dos suicidas, de Robert Louis Stevenson, em 1933:

O público lê-las-á como qualquer aventura da série Tarzan ou de Arsène Lupin, mas os entendidos sabem que aqui está um grande escritor, um grande poeta. Esperança que $O$ clube dos suicidas, que o sr. Godofredo Rangel traduziu discretamente [grifo nosso], alcance bastante sucesso para animar a Editora Nacional posteriormente os outros livros de Stevenson - o Black Arrow, tão apreciado pelas crianças, Kidnapped, Castriona, The Master of Ballantrae, todos romances de aventuras, onde, todavia, se encontram as mais puras qualidades de fundo e forma (BANDEIRA 2009, p. 118).

Se por um lado a availação da tradução feita por Bandeira parece não ser entusiasmada, por outro, era reconhecido como integrante do meio literário de seu tempo. De fato, Menotti del Picchia lhe dedica o poema "Juca Mulato"126 e Lobato chega a igualá-lo a Machado de Assis: "o unico livro nosso, embora de genero diverso, que possa ser colocado na estante entre Brás Cubas e D. Casmurro" (1972, p. 43). Arrebatado pelo texto, Lobato incita o arredio amigo a publicá-lo em livro:

Enfim, Rangel estás consagrado no nosso grupo como o grande romancista que o país esperava - e a nossa roda sabe o que diz, e o que diz é a opinião de amanhã. Queres negociar comigo a publicação de Vida Ociosa? O Monteiro Lobato editor do Godofredo Rangel - que maravilha! (LOBATO, 1957b, p. 46).

Wilson Martins (1978, p. 72) considera que Rangel foi superestimado, especialmente por Lobato: "entusiasmado com a arte literária de Rangel, com seu talento da frase e do vocabulário, com as suas virtudes estilísticas".

A produção literária de Rangel não é extensa e é praticamente desconhecida nos dias de hoje: quatro romances, uma novela, dois contos, três histórias infantis e uma gramática ${ }^{127}$. Mesmo assim, Godofredo Rangel era para Lobato simplesmente genial. A repercussão do lançamento do romance em 1921 deve-se aos comentários positivos de Lobato. Em artigo na Revista do Brasil, Lobato (1972, p. 42) é todo elogios: "obra prima do ano", "sem tachas, sem maculas", "romance novo, no tema e na forma". Curiosamente, o autor não menciona nessa resenha nenhuma só vez o nome do autor. Seguiram-se, nessa década, uma segunda edição de Vida ociosa, dois livros de contos e um romance. Depois de um hiato de mais de vinte anos, é lançada mais uma coletânea

\footnotetext{
${ }^{126}$ Menotti del Picchia faz duas dedicatórias: a primeira a Amadeu Amaral e Hermes Fontes, a segunda a Rangel e Raul Otávio da Fonseca (MARTINS, 1978, p. 87).

${ }^{127}$ Romances: Vida ociosa (1920), Falange gloriosa (1955), Os bem casados (1955) e no Reino da utopia (inédito e não concluído); novela: A filha (1929); Contos: Andorinhas (1922) e Os humildes (1944); Literatura infantil (todos de 1943): Um passeio à casa de papai-noel; Histórias do tempo do onça e A banda de música; Gramática: Estudo prático de português (1917).
} 
de contos. Os dois últimos romances de Rangel são publicados postumamente, em 1955. Antonio Candido (1955, p. 4-11) no prefácio de Falange gloriosa, embora elogie o "grande apuro na língua", aponta algumas falhas - a "tendência para o rebuscamento", a "composição lassa", o abuso de caricatura - que revelam a "candura de um romancista acanhado". Candido, todavia, avalia que as falhas não invalidam a obra, cuja maior qualidade reside sempre no "trabalho cuidadoso de redação que faz fluir docemente a narrativa".

Apesar do reconhecimento efêmero gozado por Rangel, o entusiasmo do amigo Lobato não esmorece. Escreve ele em 1934: "Estou relendo sabe o quê? A Vida Ociosa, meio de matar as saudades daquele tempo. Juro que é obra-prima até a raiz da unha. Ponho-a do lado do melhor Machado de Assis" (LOBATO, 1957, p. 326).

Edgard Cavalheiro (1955, p. 553) avalia que a admiração e a esperança depositadas por Lobato no sucesso literário de Rangel eram exageradas e concorda com Wilson Martins para quem Rangel não era o escritor que Lobato considerava; e que Lobato o "obrigara" a se transformar no romancista que ele não queria, não era, e sabia não poder ser. Martins (1978, p. 73) ainda avalia que "a expectativa criada por Lobato prejudicou de maneira inestimável o escritor porque fez que todos esperassem mais do que ele realmente poderia oferecer". Apesar de todo o esforço do amigo editor, o escritor Rangel não ficou para a posteridade:

Reina sobre ele um triste silêncio, sua obra cai no esquecimento, não é vista nas livrarias e não se fala no lançamento de novas edições. Nem mesmo o centenário de nascimento, ocorrido a 21 de novembro de 1984, alterou a situação. Afora dois números especiais do "Suplemento Literário do Minas Gerais" (947 e 948), organizados com empenho por Márcio Sampaio, apareceram algumas notas na imprensa, em geral muito superficiais (ATHANÁZIO, 1988, p. 7).

Especulam-se as razões desse oblívio: a personalidade discreta e tímida, abafada pelo magnetismo de Lobato e o afastamento dos dois polos culturais da época (São Paulo e Rio de Janeiro) por força do trabalho. Seu biógrafo atribui ao próprio Rangel esse quase anonimato: "Não há dúvida, entretanto, que contribuiu para essa situação. Nunca se promoveu ou procurou propagar o próprio nome e a sua obra. Contentava-se, parece, com a posição de 'outro lado' do célebre taubateano" (ATHANÁZIO, 1977, p. 47). Enquanto Monteiro Lobato vai se tornando extremamente popular, Godofredo Rangel embrenha-se pelo interior em vilas desconhecidas e remotas levado pelo ofício promotor, e posteriormente de juiz, que ele não apreciava: "não revelava amor pelas 
lides judiciárias [...] e parecia sentir ganas de lançar pela janela os 'gordos processos' para entregar-se de todo à literatura" (ATHANÁZIO, 1988, p. 21).

Se por um lado estima-se que o seu ofício na promotoria e magistratura acabou prejudicando a obra literária rangelina, por outro, credita-se ao trabalho de tradutor a possível causa do seu insucesso como escritor. Para Carlos Drummond de Andrade (1964, p. 78), a personalidade retraída de Rangel, aliada à necessidade de dinheiro, fez com que ele se ocultasse no "túnel da tradução", "de onde os escritores saem fatigados e sem rosto". Fernando Góes concorda: "Gastou-se traduzindo infatigavelmente uma série enorme de livros de toda a espécie, o que, por certo, impediu-lhe de construir a obra que Lobato esperava de seu engenho" (GÓES, 1958, p. 232).

De fato, analisando a quantidade de obras traduzidas, imagina-se o tempo que a atividade lhe consumia: foram 36 títulos somente na década de 1930. O volume total é tal que em 1941 levou Lobato (1957b, p. 337) a exclamar: "60 livros já traduziu você? Tremendo! Eu não sei quantos tenho, nem quero saber". Nelo Rangel, o falecido filho, afirmava que andavam perto de uma centena e Enéas Athanázio conseguiu relacionar 51, "incluindo algumas [traduções] revistas só por ele" (ATHANÁZIO, 1988, p. 30). Contudo, essa lista publicada no fim do opúsculo "O amigo escrito" não traz os dados bibliográficos completos e em muitos casos grafa errado, ou troca, o nome dos autores.

Como acntece com muitos literatos de seu tempo, a tradução constituía para Rangel um meio de complementar a renda, mas muito antes de ganhar dinheiro com a atividade Rangel já traduzia por diletantismo: "Godofredo Rangel foi incansável tradutor das línguas inglesa e francesa. Já na juventude, por mero prazer traduzia Hugo para 'manter a forma' e 'ganhar o ritmo'. Por satisfação assim continuou" (ATHANÁZIO, 1977, p. 90). O primeiro registro de traduções encomendadas é de 1926 e, na realidade, seriam mais adaptações para crianças de trechos de Shakespeare, para a coleção "Shakespeare dos Meninos", da Cia. Gráfico-editora Monteiro Lobato.

Aparentemente, Rangel foi levado a traduzir para a Companhia Editora Nacional pelas mãos de Monteiro Lobato e a maior parte das traduções realizadas por ele foi para essa casa. O volume de traduções é tão grande que leva Lobato (1957b, p. 310) a comentar: "Achei-o mais magro. É de tanto traduzir livros de moças ${ }^{128}$, creio. O Otales 129 explora-o infamemente". Somente entre 1930 e 1940, Rangel traduziu 39 títulos,

\footnotetext{
${ }^{128}$ Referência aos livros da coleção Biblioteca para Moças.

${ }^{129}$ Octalles Marcondes Ferreira, então proprietário da Companhia Editora Nacional.
} 
sendo 17 de literatura de ligeira. Em 1936 foi ano em que mais traduziu: um total de oito obras.

Além das parcerias que fez com Monteiro Lobato, ora de revisão ora de tradução conjunta (como a obra de Will Durant, já citada), Rangel traduziu duas obras "a quatro mãos" com Anísio Teixeira: Democracia e educação, de John Dewey, 1936 e A ciência da natureza humana, de Alfred Adler, 1939.

\begin{tabular}{|c|c|c|}
\hline 1930 & O caminho da felicidade & Victor Pauchet \\
\hline & Os filhos: sua preparação para vida & Victor Pauchet \\
\hline & Por que os homens falham? & F Morris; W White \\
\hline 1931 & A tragédia da minha vida, & Oscar Wilde \\
\hline & O sheik & E M Hull \\
\hline 1932 & A Esposa que não foi beijada & Betha Buck \\
\hline & A vida de Santo Agostinho & G Papini \\
\hline 1933 & O clube dos suicidas & Robert K Stevenson \\
\hline & As Cruzadas & E Barrington \\
\hline & Como pensamos: como formar e educar o pensamento & John Dewey \\
\hline & Lógica & L. Liard \\
\hline & O corsário vermelho & John F Cooper \\
\hline 1934 & O homem do Hotel Carlton & Edgar Wallace \\
\hline & Sede optimistas & Victor Pauchet \\
\hline & O Pimpinela escarlate & Bez. Orczy \\
\hline & Mulherzinhas & Louise May Alcott \\
\hline & It & Elinor Glynn \\
\hline & O tesouro das ilhas Galápagos & AndréArmandy \\
\hline 1935 & Tarzan o filho da jângal & Edgar R Burroughs \\
\hline & O filho de Tarzan & Edgar R Burroughs \\
\hline & Vendida & W Heimburg \\
\hline & Francesca & Cecil Adair \\
\hline 1936 & Scaramouche & R Sabatini \\
\hline & A vida de Disraeli & André Maurois \\
\hline & A porta dos traidores & Edgar Wallace \\
\hline & Perdidos no deserto & Mayne Reid \\
\hline & A ilha de coral & R Ballantine \\
\hline & Ofantasma de Sandokan & Emilio Salgari \\
\hline & As cruzadas, os homens de ferro e os santos & Harold Lamb \\
\hline 1937 & História da civilização & Will Durant \\
\hline & O outro milagre & Henri Ardel \\
\hline 1938 & Guilherme, o grumete & Mayne Reid \\
\hline & Cinzas do passado & Myrtle Reed \\
\hline 1939 & Oscar Wilde, sua vida e confissões & Frank Harris \\
\hline & Os judeus e nós os cristãos & O Férenzy \\
\hline 1940 & Maravilhas da medicina & David Dietz \\
\hline
\end{tabular}




\begin{tabular}{|l|l|l|}
\hline Noites de vigília & A J Cronin \\
\hline O crime da casa solitária, & Ellery Queen \\
\hline Pupila sem tutor & Charles Foley \\
\hline
\end{tabular}

Tabela 4: Relação das traduções realizadas por Rangel entre 1930-1940 ${ }^{130}$

Rangel torna-se, desde o início da amizade com Lobato, um colaborador confiável e constante. As cartas de Lobato em A barca de Gleyre dão a conhecer um Rangel cultor da língua portuguesa, que frequentemente criticava e corrigia o famoso escritor e editor, ao que este retrucava com humor: "Que redada de cincas de gramática apanhou você em meus escritos, ó gramaticão de má sorte, ó Candido Figueiredo de Santa Rita!" (LOBATO, 1957b, p. 39). Além de questões gramaticais, a crítica de Rangel também envolvia aspectos estilísticos e literários. Nada escapava ao seu crivo e Lobato acatava as sugestões: "Segue os teus Mãe e Exame e o meu Bocatorta refundido - e creio que melhorado. Teus conselhos abriram-me os olhos. Como estava infame o outro" (LOBATO, 1957a, p. 238).

Desde os tempos do Minarete, Rangel mostrava-se zeloso com a escrita: "Rangel trabalhava como louco em caçadas minuciosas de "quês" de inúmeros contos escritos uns em cima dos outros, estudando Daudet e Zola, traduzindo Victor Hugo para ganhar ritmo" (CAVALHEIRO, 1955, p. 82). Posteriormente como autor, Rangel continuou a esmerar-se, levando Antonio Candido (1955, p. 3) a qualificá-lo de escritor "caligráfico" pela maneira como o romancista é sensível "à beleza formal da página" e é minucioso na escrita "caprichando os traços e embelezando as palavras pelo talhe elegante da letra". Dessa maneira, deduz-se que esse mesmo cuidado com que escrevia seus textos e corrigia os do amigo tinha-o com as traduções que fazia.

Diferentemente dos outros dois tradutores aqui estudados, a atividade de Rangel como tradutor foi negligenciada pelos Estudos da Tradução no Brasil. Seu nome não consta nem mesmo no abrangente Dicionário de tradutores literários no Brasil, da UFSC, que alega optar por "incluir inicialmente os tradutores mais representativos, entre eles os tradutores-escritores, os tradutores que traduziram obras relevantes do ponto de vista estético ou histórico e também os tradutores que traduziram um grande número de obras".

\footnotetext{
${ }^{130}$ A relação das traduções realizadas por Rangel foi compilada a partir de informação no opúculo $O$ amigo escrito (op cit.), de referências na Barca de Gleyre e na Estante Virtual.
} 
A inexpressividade literária de Rangel fora do seu círculo de escrtores de seu tempo e a circunstância profissional que o levou longe dos polos culturais podem ser apontados como fatores importantes no pouco interesse que sua atividade de tradutor despertou. "Godofredo Rangel não conserva seu lugar na memória crítica e historiográfica" (MARTINS, 1978, p. 71), nem mesmo como tradutor. 


\title{
5. ANÁLISE E DISCUSSÃO DE DADOS
}

\author{
This is the hour of pride and power \\ Talon and tush and claw \\ Oh, hear the call - Good hunting all \\ That keep the jungle law!
}

The jungle book, Rudyard Kipling

A mediação editorial sempre ocorre na publicação de qualquer obra e quando ela está inserida em uma coleção, a intervenção estabelece parâmetros de uniformização, que se dá tanto no aspecto material do livro, quanto no textual. John Milton (2002, p. 94) elenca diferentes tipos de padronização: temática, estilística, de linguagem e de tamanho e peso (no caso de o livro ser distribuído pelo correio).

A coleção Terramarear obedece a uma uniformização que lhe confere identidade visual e conteudística. Com relação à temática, conforme já mencionado, a coleção privilegiava o leitor jovem, com obras do gênero aventura. A padronização material, em conformidade com a concepção de coleção, se impõe a todos os peritextos e, também, às dimensões do livro.

Com relação à série Tarzan, os livros apresentam regularidade quanto ao tamanho: medem catorze por vinte e um centímetros, pesam cerca de trezentos gramas e possuem por volta de duzentas páginas. Vale anotar que Tarzan, o destemido, tradução de Basílio Machado, de 1935, por ter uma história mais longa, foi lançado em dois volumes, aparentemente para manter a mesma dimensão dos outros volumes.

Conforme já mencionado, o corpus deste estudo compreende três livros traduzidos do inglês, componentes da coleção Terramarear: O tesouro de Tarzan, tradução de Manuel Bandeira (1934), Tarzan, o terrível, tradução de Monteiro Lobato 
(1935) e Tarzan, o rei da jângal, tradução de Godofredo Rangel (1935). Nos três, obviamente, Tarzan é personagem principal e em dois, $O$ tesouro de Tarzan e Tarzan, $o$ terrível, a aventura envolve também sua companheira Jane. A história é um desenrolar de intrigas e contra-intrigas envolvendo europeus e nativos, que se subdividem em grupos dos bons e dos maus.

Em $O$ tesouro de Tarzan, Lord Clayton na persona de Tarzan retorna à mítica cidade de Opar para buscar ouro, ua vez que perdera grandes somas no mercado financeiro londrino. Um desertor do exército belga se associa a um bando de árabes e, a serviço deles, segue Tarzan para opossar-se do tesouro. Enquanto Tarzan está fora, os árabes sequestram Jane e põem fogo na propriedade. $\mathrm{O}$ desfecho é sempre aquele constante na cultura popular, um happy end: após muitos percalços Tarzan liquida os inimigos, recupera a companheira e o ouro.

A narrativa de Tarzan, o terrível se inicia dois meses depois de outro desaparecimento de Jane. Ele segue sua pista até um vale perdido, de ambientação préhistórica. O perigo se apresenta na forma de uma espécie de dinossauro carnívoro e dos feiticeiros de uma cidade perdida, que praticam sacrifício humano. Tanto Tarzan quanto Jane são salvos pelo filho Korak, que vinha há muito procurando pelos pais. Se essas duas histórias apresentam o homem-macaco envolvido com seus próprios negócios e família, O rei da jângal, por sua vez, apresenta o herói como um aventureiro sem raízes atuando como salvador dos fracos. Além dos indefectíveis árabes hostis, fazem parte da trama, fantasiosos cavaleiros medievais herdeiros dos cruzados, que vivem em um castelo fortificado no meio da selva. Enquanto cada história inclui novas personagens e diferentes lugares, sempre exóticos, as coincidências, as peripécias, a selva, os nativos africanos e a associação de Tarzan com os animais são uma constante em todos os livros.

Com relação ao estilo e à linguagem será investigado se assim como há uma padronização "material" das obras da série Tarzan se haverá uma padronização nas traduções e, também, se os casos de omissão ocorrem para adequá-las ao tamanho dos livros ou se resultam de escolhas de cunho ideológico, uma vez que a condensação pode ser dar por questões editoriais que estimam a inadequação ao público ou por intenção do tradutor.

Este trabalho percorre uma trajetória diferente daqueles que priorizam o referencial do original como único fator decisivo no resultado, levando em conta o papel 
da tradução na cultura receptora e como esta influencia a tradução, numa análise de mão dupla. Dentro dessa visão, o ato tradutório transcende à simples transposição de um sistema linguístico a outro, numa busca de equivalências. A análise inicia-se não com o original, mas com os peritextos, pois com eles que a obra passa do plano abstrato para o concreto e é neles que se coloca em cena um efetivo diálogo com o leitor.

\subsection{Os epitextos e peritextos}

Ao ser publicado, o texto se torna objeto e passa a observar uma codificação editorial, que seria a "normalização do livro naqueles aspectos que não concernem à substância de sua mensagem, mas que informam a substância de sua mensagem" (HOUAISS, 1967, p. 4).

Para garantir sua a presença novo contexto, sob a forma de livro, a instância editorial lança mão de recursos de divulgação, que exteriores a ele, divulgam e promovem a leitura. O catálogo da Coleção Terramarear, não só relaciona as obras publicadas e a publicar, como as classifica de "clássicos da literatura mundial", define o jovem como seu público leitor e intima os pais a comprá-las. Uma citação de Monteiro Lobato avaliza a qualidade das obras. Vale observar que na relação de próximas publicações consta a tradução de $O$ tesouro de Tarzan como sendo de Agripino Griecco e não de Manuel Bandeira. Difícil precisar se trata-se de um engano ou se houve troca de tradutor após a publicação do catálogo.

Nas figuras do catálogo de 1934, a seguir, estão relacionados vinte e três títulos publicados, precedidos do nome do autor e identificando os tradutores. Ainda são anunciadas seis publicações futuras. 


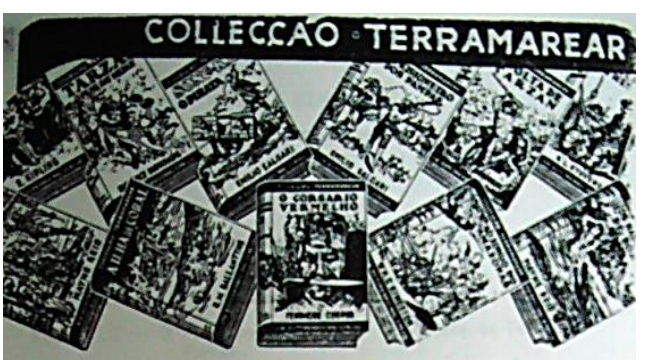

Livros para a juventude, cuidadosamente escolhidos entre as obras classicas da literatura mundial.

AVENTURAS, VIAGENS, HISTORIA, ESPORTES, HEROISMOS :

Brochura - 35000 - D Encadernados, mais - 25000 - B

"Dur sos meninos bons lirres a deguedes a idade 6 o mellor meio do formar bomens". Mostrino Losuto.

Náo basta aprender a ler. $E^{\prime}$ preciso que o menino depuis que sabe ler, leia! Mas ler que tivros? Le

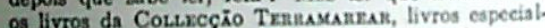
mente feitos para as mentros, para a juventude em réral. Oa paes estão no dever de dar aos seus fithos to dos os livros desta preciosa collecę5ro.

35

\section{GUSTAVO LE ROCGE}

Vol. XIV - 0 Naufrago do Espaco - Tratuctio de Adrieso de Abres.

RUDYARD KIPLINC

Vol. XV - Jacala, o Crocodilo - Thadoçdo de Mosteine Lobsto.

EMILIO SALOARI

VoL. XVI - Arenturas de am Garimpeire - Thdoeds do Buelides Aodrate.

BDGAR RICE BURROUGHS

Vol, XVII - As Fins de Terran - Tradeeglo de Medeirse Alboguerọite.

\section{MAYNE ROD}

Vol. XVIII - Os naufrages do Ygapo- Thd de Tiso Marcede

\section{MARK TWAIN}

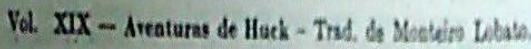

EMILIO SALGARI

Vol. II - Song-Kay, o Pirata - Traduegho reviata por Julio Cesar da Siva.

III - O Prisioneiro dos Pampas - Idem.

MAYNE REID

Vol. IV - Os Naufragos de Bornce - Trad. revists per Mt. L.

Vol. $\quad \mathrm{V}-0$ s Negreiros de Jamaica - Idem.

EDGAR RICE BURROTGHS

VoL. VI - Tarzan, o Filho das Selvas - Traductó de Al.

Vol. VII - A Volta de Taraan - Tradaçio de Merilla Torres ROBERT-LOUTS STEVENSON

Vol VIII - A Itha do Thesouro - Traduçlo de Araso Eateo J. FENIMORE COOPER

Vol. IX - O Consario Vermelho - Traduçio selectiocada de Rsul de Politio

R. M. BALLANTYNE

Vol. X - A tha de Coral - Traduegho seleceicesada de Ger doltredo Raszol

w. II. G. KINGSTON

VoL. XI - Ao Longo do Amanonas - Tradurefo selectioneads de Julio Ceast da Stra.

No prelo, a sabir at6 Setembro 1993 :

Vol. XII - JACX Lovbos - Canises flanees - Trafuesto de Moteteire Lobate

Vo. XII - Masx Twats - O Priadipe e e Pobre - Traduept. de Paubo de Freilas

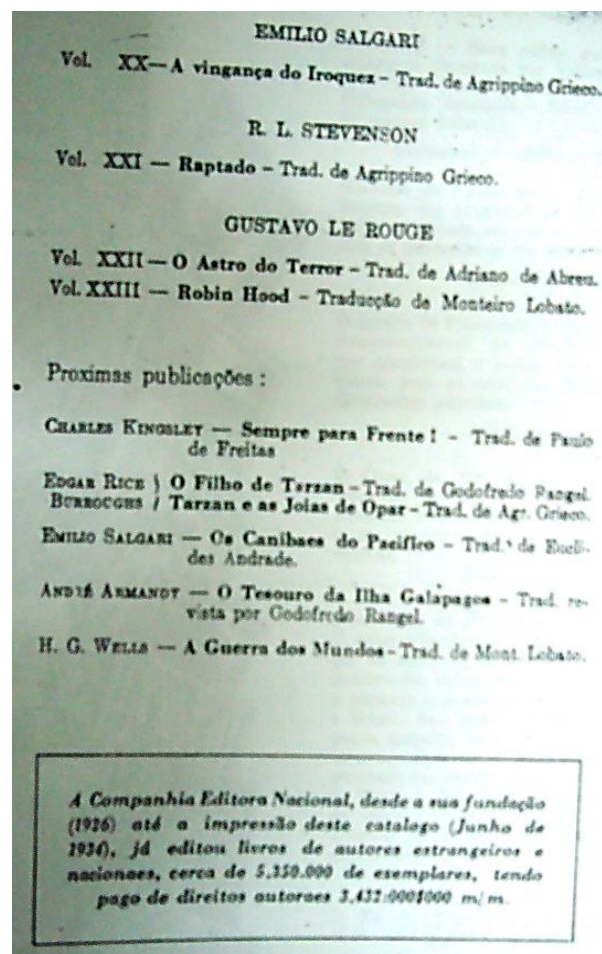

Figura 7: Catálogo da Coleção Terramarear de 1934 
O corpo material do livro é composto pelo revestimento e o miolo, que tradicionalmente são espaços editoriais: capa, folha de rosto, contracapa e orelha, além de prefácio e notas. O editor da obra traduzida agirá como um "filtro" dos elementos que deseja, ou acha apropriado, transpor para a cultura receptora.

$\mathrm{Na}$ obra traduzida os paratextos podem tanto pôr em relevo o seu caráter derivativo, aqui sem nenhuma conotação negativa, como totalmente encobri-lo. Alguns desses espaços, por não serem obrigatórios, apresentam diferentes graus de presença do tradutor. A existência de notas, prefácio do tradutor, por exemplo, "constitui evidência do status do tradutor na cultura receptora e relativamente ao autor original" (E. VIEIRA, 1982, p. 151). Uma vez que os peritextos contribuem para que o texto se torne um objeto a ser recebido pelo leitor, a sua análise se faz necessária para se revelar o aspecto exponencial da tradução, conforme analisa Else Vieira (p. 147):

Dentro da organização espacial do livro traduzido, o espaço liminar, duplamente intitulado [título original e traduzido], assinado, datado, localizado e editado, configura um entre-lugar entre dois sistemas linguísticos, dois regimes de autoridade/autoria, duas cronologias, dois mundos e dois sistemas de propriedade, caracterizando, assim, um espaço de transição que permite a passagem de um regime ontológico a outro.

Assim, levando em conta a dimensão cultural e política dos paratextos e sua significação na obra traduzida, e tendo já sido abordado a questão do epitexto no capítulo 3, a análise se iniciará a partir do exterior do livro antes de se chegar ao texto em si.

\subsubsection{O revestimento do livro}

Para Antônio Houaiss (1967, p. 46) a denominação genérica de revestimento do livro como objeto se constitui das seguintes partes: capa stricto sensu, contracapa, orelha e dorso (ou lombada). A capa apresenta a obra ao leitor, provocando nele diferentes respostas. Elas tanto podem atrair como repelir ou deixar o leitor indiferente. Assim o adágio We can't tell the book by its cover ${ }^{131}$ pode ser verdadeiro metaforicamente, no sentido de que não se deve julgar pela aparência, todavia, no sentido literal ele vai de encontro aos estudos sobre os elementos peritextuais, especialmente na obra traduzida.

\footnotetext{
${ }^{131}$ Não se pode julgar o livro pela capa.
} 
Valendo-se dessa função anunciadora, a indústria editorial da década de 1930 propunha capas mais chamativas para atrair leitores fora do circuito intelectual. Tradicionalmente, as capas duras em cores sóbrias eram associadas a obras "sérias", porque, segundo Alan Powers (2008, p. 41): "No mundo da edição de livros para adultos, as sobrecapas pictóricas eram menosprezadas como um artifício que atraía leitores incultos a comprar livros por meio de imagens superdramatizadas". Essa opinião é compartilhada por Perry Nodelman (1988, p. 44):

Esperamos uma literatura mais sofisticada de livros de capa dura texturizada e monocromática e uma mais convencionalmente popular de livros com capas plastificadas espalhafatosamente coloridas. Somos inclinados a pensar diferentemente com relação à brochura e à capa dura, e como consequência reagiremos diferentemente à mesma história em diferentes formatos; o que parece intimidativo ou respeitoso em capa dura, frequentemente parece descartável e inofensivo em capa mole ${ }^{132}$.

Entretanto, a capa não só modifica o julgamento do leitor com relação ao conteúdo do livro, mas também transcende a função de somente prenunciar e proteger a obra. Conforme registra Allan Powers (2008, p. 40): "A partir de 1920, os editores se tornaram mais conscientes de que as vendas poderiam ser alavancadas com a aparência externa do livro - algo que talvez seja óbvio para nós hoje, mas que foi aceito com relutância pela conservadora indústria editorial".

No Brasil, por volta de 1920, apesar de a capa típica ser apenas "a reprodução, em papel cinza ou amarelo, dos caracteres tipográficos que apareciam na página de rosto" (HALLEWELL, 1982, p. 251), observa-se um número significativo de capas ilustradas, com predominância nas edições de poesia sobre os demais gêneros literários, segundo pesquisa de Yone Soares de Lima (1985, p. 107): "Regra geral as publicações desta natureza proporcionaram ao ilustrador maior liberdade para suas interpretações artísticas que variaram do figurativo ao convencional, realista, à mais criativa das fantasias".

Contudo, não eram obras que interessavam ao grande público, mas aquelas consumidas pelo círculo mais letrado. Mesmo as obras modernistas, cujas capas foram realizadas por artistas da época, eram discretas se comparadas com aquelas chamativas

\footnotetext{
${ }^{132}$ We expect more distinctive literature from hardcover books with textured, one-color covers and more conventionally popular material from books with luridly colored plastic coatings. We tend to think differently about paper-covered books and one with hard covers, and as a result we respond differently to the same story in different formats; what might seem forbidding and respectable in hardcover often seems disposable and unthreatening in soft.
} 
encomendadas por Monteiro Lobato para sua editora. Nos anos 1930, as editoras começaram a lançar livros com capas coloridas e ilustradas, pois era artifício importante na popularização e vendagem dos livros. O pragmatismo editorial é confirmado pelas palavras de Antônio Houaiss (1967, p. 51): "Os dizeres e os desenhos da capa flutuam de acordo com o formato, o destino, o conteúdo, a finalidade, a natureza temática e o estilo da editora do livro".

Entre o fim do século 19 e a Primeira Guerra Mundial, o desenvolvimento tecnológico tornou possível a reprodução mecânica de uma ilustração, anteriormente copiada à mão, barateando o custo e ampliando as possibilidades criativas do artista. Convencidos de que as capas ilustradas anunciavam de maneira imediata ao pretenso comprador o que ele iria ler, a Companhia Editora Nacional, obedecendo aos objetivos comerciais editoriais de atrair o jovem leitor, lança a série da coleção Terramarear com capas chamativas e uniformizadas quanto à diagramação, próprias das características de coleção.

A análise dos elementos da capa, enquanto "parte integrante da história de qualquer livro", pode revelar "o impacto que o editor desejava causar nos leitores" (POWERS, 2008, p. 6). Assim, a ilustração de cores fortes, beirando ao kitsch, ao mesmo tempo que prenuncia a aventura com a representação de personagens em luta ou de animais exóticos, revela o tipo de leitor que a editora deseja atingir:
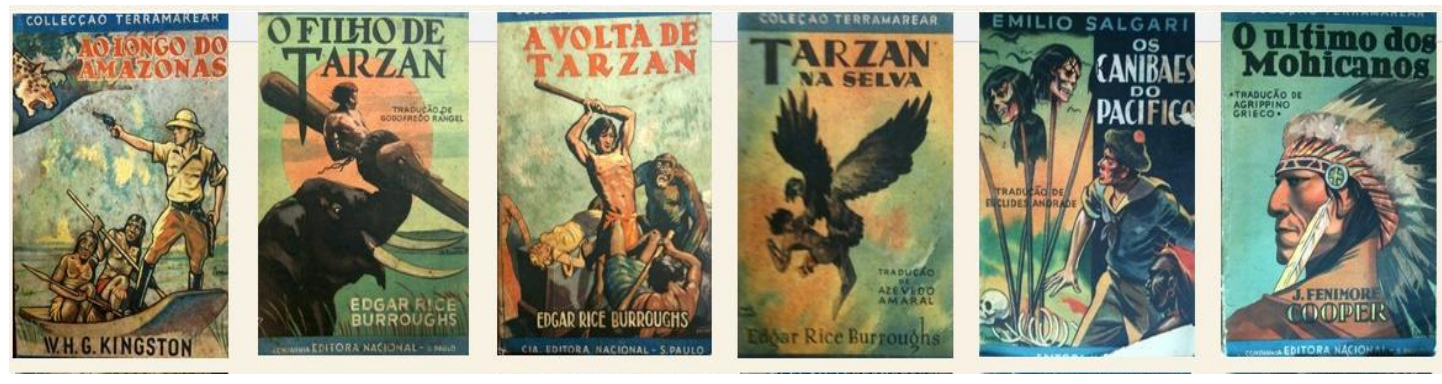

Figura 8: Capas de algumas publicações da coleção Terramarear ${ }^{133}$

A maioria das capas da coleção Terramarear foi realizada por Jurandyr Ubirajara Campos, genro de Monteiro Lobato, fato que, aparentemente, pode ter influenciado na contratação de seu serviço. Contudo, não foi um ato de puro nepotismo, pois Jurandyr

\footnotetext{
${ }^{133}$ https://www.google.com.br/search?q=cole\%C3\%A7\%C3\%A3o+terramarear\&biw=1280\&bih=601\&tb $\underline{\mathrm{m}=i s c h \& t b o=u \& \text { source }=u n i v \& s a=X \& e i=6 \mathrm{LMmVIDCENSNNob8gcgB \& ved}=0 \mathrm{CCs} Q 7 \mathrm{Ak}}$
} 
Campos já era um artista reconhecido. Ele inicia suas atividades como desenhista comercial fazendo publicidade para um estabelecimento comercial de máquinas. Em 1928, embarca para Nova York e trabalha para The New York Times. Lá conhece a filha mais velha de Lobato, Marta, com quem se casa. Em 1930, retorna ao Brasil e vai trabalhar para $O$ Estado de São Paulo e ilustra os livros infantis do sogro. A partir de 1940, dedica-se somente à pintura e em 1950 se torna presidente do Salão Paulista de Belas Artes.

Nas capas da série Tarzan, o apelo comunicativo costuma ser desencadeado a partir de uma ilustração "narrativa" de estética pouco refinada e cumpre o seu papel como artifício na popularização do livro. Nessas capas já se desvelam indícios da apropriação que ocorre num processo tradutório: o nome de outra editora, o nome da coleção, o nome dos tradutores e o título na língua alvo, só permanecendo inalterado o nome do autor, mudanças essas vinculadas à transferência da obra para um novo contexto de recepção, garantindo sua sobrevida.

As ilustrações das capas dos livros de Tarzan analisadas neste estudo apresentam uma peculiaridade. São reproduções das capas americanas, idealizadas por J. Allen St. John, publicadas nos Estados Unidos pela editora A. C. McClurg. Apesar de assinadas por Campos, ele não se apropria indebitamente delas: sobre a identificação "J U CAMPOS" acha-se a abreviatura "ADAPTda". A adaptação pode ter se dado por diversas razões: imposição do editor e/ou autor do original, atualização técnica, uma vez que entre as publicações americana e brasileira transcorreram mais dez anos e, provavelmente, tenha havido um desenvolvimento na produção gráfica nesse período que requereu adequação, ou ainda para seguir a padronização da série. As capas feitas no Brasil se aproximam do estilo de ilustração, mais adequada para impressão, enquanto as capas americanas se assemelham a pinturas de quadros. Isso é compreensível, pois Saint-John era, sobretudo, um pintor que estudou em Paris, de 1906 a 1908, e foi, posteriormente, professor no Chicago Art Institute e na American Academy of Art. Por sua vez, Campos trabalhou mais como ilustrador, voltando-se para a pintura tardiamente. 


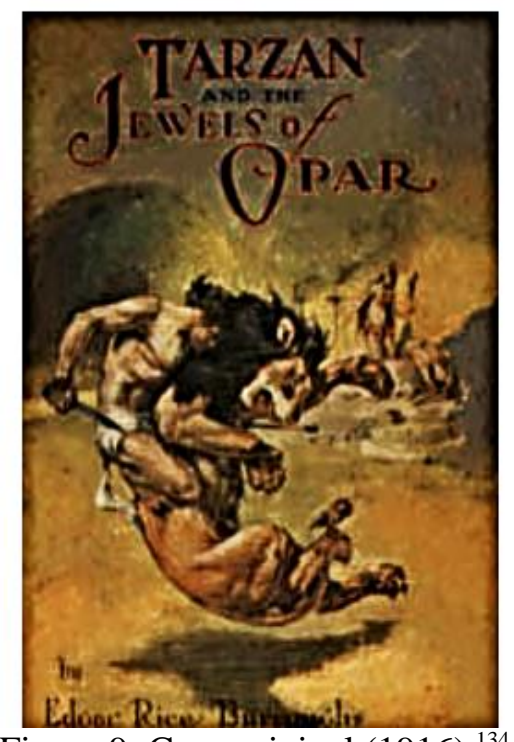

Figura 9: Capa original (1916) ${ }^{134}$

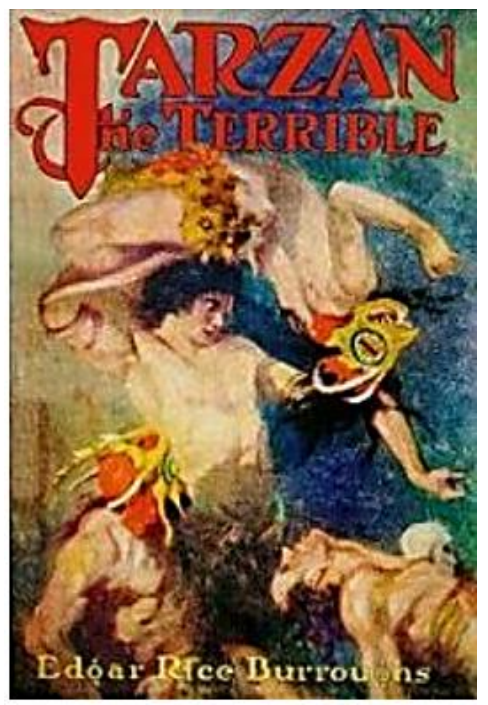

Figura 11: Capa original (1921)

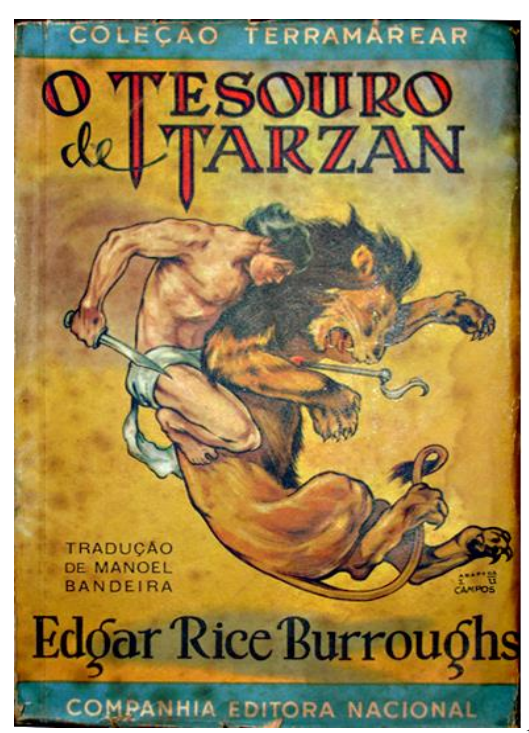

Figura 10: Capa tradução (1932) ${ }^{135}$

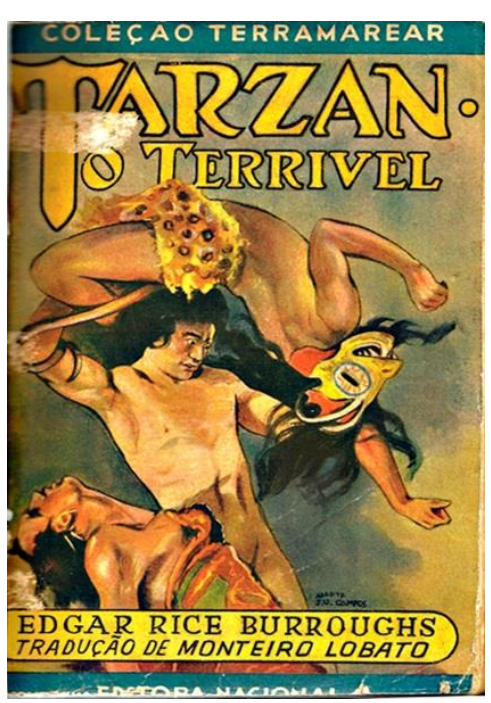

Figura 12: Capa tradução (1935)

${ }^{134}$ Capas americanas: http://en.wikipedia.org/wiki/Edgar_Rice_Burroughs Capas nacionais: arquivo do autor. 


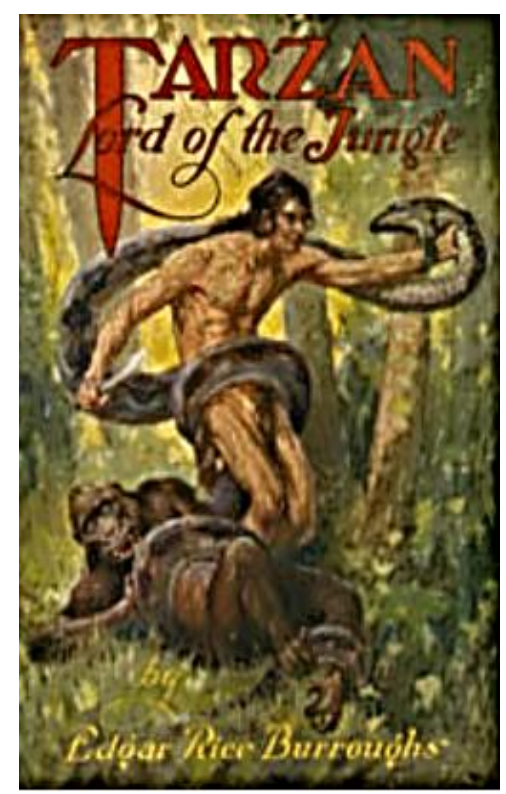

Figura 13: Capa original (1927)

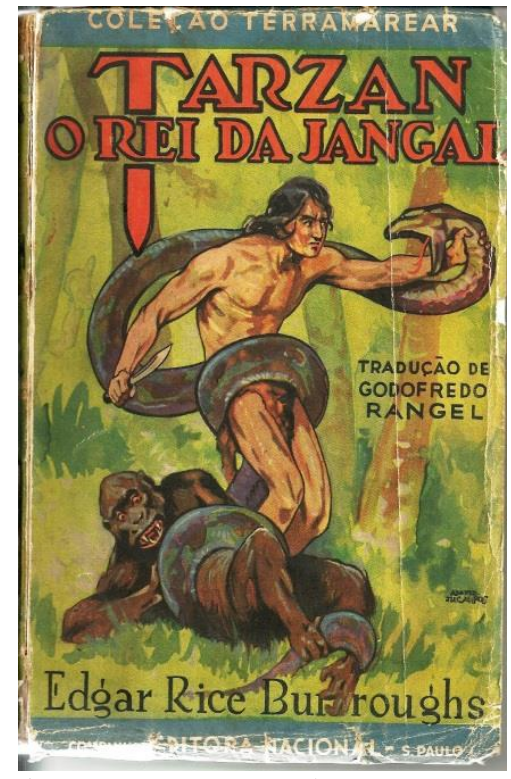

Figura 14: Capa tradução (1935)

Sendo as capas brasileiras mais limpas em elementos, principalmente com relação ao tratamento dado ao fundo, o olhar não se perde e a tensão é voltada para a figura central do protagonista dominando os antagonistas. De todos os elementos que compõem uma ilustração, o esquema cromático é o que primeiramente chama a atenção pelo seu aspecto emocional (NODELMAN, 1988, P. 141). Nas capas brasileiras, as cores são mais vibrantes e esse contraste estabelece uma atmosfera maior de ação. As combinações de cores contrastantes, assim como a quantidade de elementos, apelam para sentimento de excitação e energia. $\mathrm{O}$ amarelo, em $O$ tesouro de Tarzan e Tarzan o terrível, e o vermelho nos títulos, prenuncia uma história vívida. O fundo verde de Tarzan, o rei da jângal sugere a densidade da selva e põe em relevo o corpo acobreado do herói. As cores quentes são realçadas pelo azul das faixas que identificam a coleção. Esses aspectos da ilustração vão ao encontro da característica de movimento, de "imagem falada", na obra de Burroughs com suas descrições de ação.

A capa dos livros de Tarzan é, concomitantemente, arauto e tradução em linguagem pictórica de um texto preexistente, que concomitantemente confirma e torna mais específica a imagem do herói. Em Tarzan, o terrivel, a capa reproduz a indumentária dos sacerdotes de uma seita inventada por Burroughs, os quais Tarzan enfrenta em algumas ocasiões, descrita no capítulo 13:

Era uma enorme mascara esculpida num bloco inteiriço de madeira escavado por dentro até tornar-se uma casquinha. Na parte inferior do pescoço adaptavam-se tiras de couro cabeludo, com longos cabelos escorridos. Tarzan compreendeu que 
as vitimas sacrificadas na ara de Jad-ben-Otho eram escalpadas para fornecer aos sacerdotes essa peça indumentária. A caraça representava uma cabeça monstruosa, mixta de grifo e homem, com os três chifres do triceraptos e aquele circulo azul que tais mostram em redor dos olhos (p. 108).

The thing had been very cunningly wrought from a single block of wood, very probably a section of a tree, upon which the features had been carved and afterward the interior hollowed out until only a comparatively thin shell remained. Two-semicircular notches had been rounded out from opposite sides of the lower edge. From these aprons hung long tassels or switches of hair tapering from the outer edges toward the center which reached below the bottom of his torso. It required but the most cursory examination to indicate to the ape-man that these ornaments consisted of human scalps, taken, doubtless, from the heads of the sacrifices upon the eastern altars. The headdress itself had been carved to depict in formal design a hideous face that suggested both man and GRYF. There were the three white horns, the yellow face with the blue bands encircling the eyes and the red hood which took the form of the posterior and anterior aprons.

Contudo, cotejando tradução com o original da descrição desses três episódios, nota-se que pela extensão da tradução do excerto de Tarzan, o terrível muita informação é omitida. A leitura aponta que o original é muito mais detalhado na descrição da indumentária dos sacerdotes. Resumo e edição ocorrem frequentemente na tradução de Lobato, conforme será discutido na análise do texto. Já a capa de $O$ tesouro de Tarzan descreve a luta entre o herói e Numa, o leão, no capítulo 3:

No mesmo instante o homem-macaco deixou-se cair de um galho, bem sobre o dorso do felino e ao por-lhe pé cravou a faca atrás da espadua esquerda da fera, enfiou os dedos da mão direita na longa juba. Enterrou os dentes na garganta de Numa e cingiu nas pernas possantes o torso do carnívoro. Com um rugido de dor e sanha, Numa empinou-se e caiu para trás sobre o homem- macaco (p. 21).

At the same instant the ape-man dropped from an overhanging limb full upon the lion's back and as he alighted he plunged his knife into the tawny side behind the left shoulder, tangled the fingers of his right hand in the long mane, buried his teeth in Numa's neck and wound his powerful legs about the beast's torso. With a roar of pain and rage, Numa reared up and fell backward upon the ape-man.

Por sua vez, a prioridade descritiva da capa de Tarzan, o rei da jângal é o momento em que Tarzan salva Bolgani, o gorila, da constrição da serpente Histah, no capítulo 4:

Já Histah havia rodeado o tronco e uma das pernas do homem-macaco, mas seu poder de constrição, diminuido pelos terriveis ferimentos que recebera, era incapaz de esmagar, sem permitir reacção, o adversario; e agora toda a attenção de Tarzan se concentrava em golpear com a lamina da faca de caçador, num só lugar, o corpo debilitado da serpente, para tentar partil-a em dois pedaços (p. 37).

Already Histah had encircled the torso and one leg of the ape-man, but his powers of constriction, lessened by the frightful wounds he had received, had as yet been 
unable to crush his adversary into helplessness, and Tarzan was now concentrating his attention and the heavy blade of the hunting knife upon a single portion of the weakening body in an attempt to cut Histah in two.

O ilustrador traduz em desenho o texto e faz com que o leitor visualize a cena já antecipada pela capa ao lê-la. Pelo seu aspecto narrativo, a ilustração das capas aproxima-se daquela utilizada nas histórias em quadrinhos, contudo, difere na concepção plástica, na técnica e no estilo.

O aspecto viril de Tarzan, representado nas capas, e descrito nas histórias, corresponde ao ideal greco-romano, que valoriza as proporções perfeitas, o equilíbrio, o ritmo e a harmonia, em concordância com a visão e o gosto que refletiam um romantismo ainda persistente no ideário academicista do século 20. A preferência por esse modelo é herança do apogeu das academias de belas artes do século 19, que encorajadas pela ascensão da burguesia replicavam a estética renascentista. As manifestações dos movimentos modernistas eram incompreensíveis e de difícil aceitação, assim persistiu no gosto geral a estética passadista.

O gestual caracterizado pela força e o aspecto escultório dos desenhos das capas dos livros do corpus remetem ao mitológico Hércules, representado em várias estátuas, tanto do período greco-romano como renascentista. As ilustrações das capas não somente reproduzem o físico do grego como também lembram os seus movimentos de ataque às feras, como se pode observar em algumas das esculturas do herói grego:

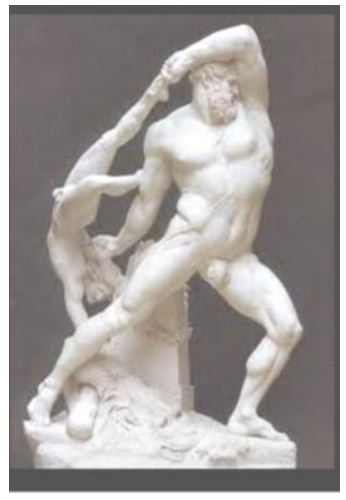

Figura 15
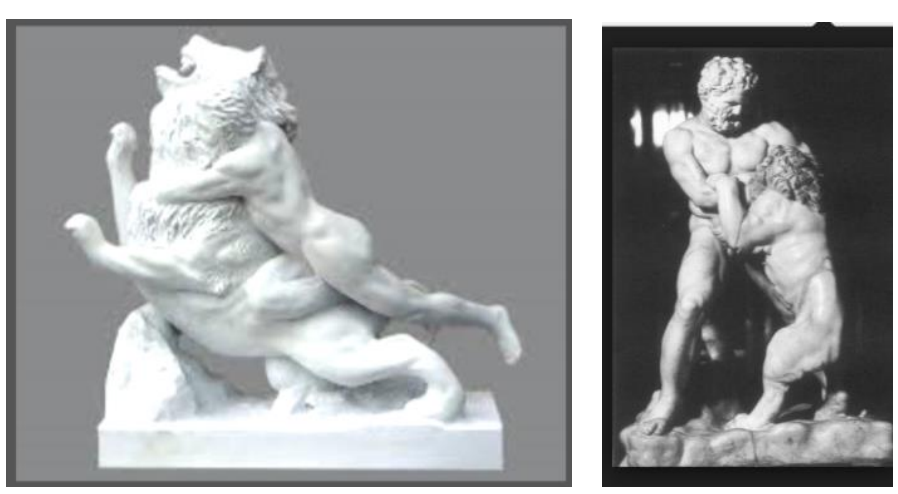

Figura 16 e 17: Hércules e o Leão de Neméia ${ }^{136}$

Hércules e Cacus

\footnotetext{
${ }^{136}$ Imagens de Hércules:

https://www.google.com.br/search?q=est\%C3\%A1tuas+de+h\%C3\%A9rcules\&biw=1280\&bih=601\&tbm =isch\&tbo=u\&source $=$ univ\&sa=X\&ei=w7UmVOehEYrKggSKxYGoDQ\&ved=0CBwQsAQ
} 


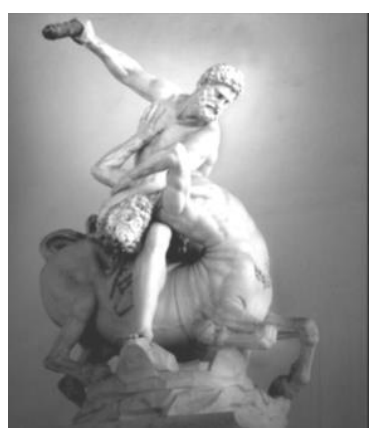

Figura 18
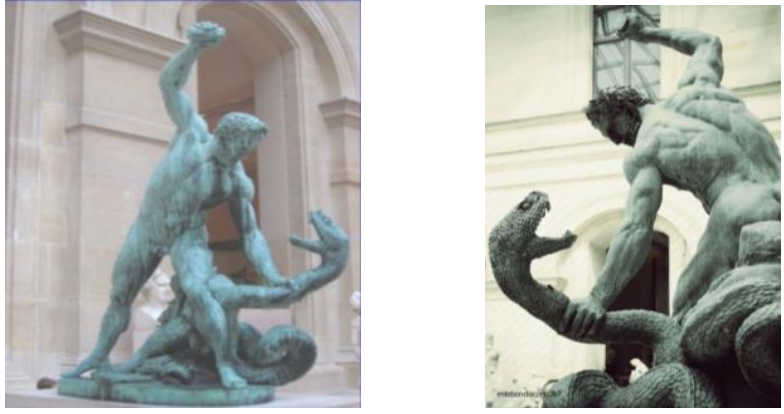

Figura 19 e 20: Hércules e a Hidra de Lerna

Hércules e o centauro

Em uma comparação simplista, ainda que plausível, a analogia entre Hércules e Tarzan se estende, de certa forma, tembém à história. Assim como o herói semideus da mitologia grega, filho de Zeus com a mortal Alcmena, Tarzan, herói de uma mitologia moderna, pode ser identificado pela sua força e coragem. Tarzan, como Hércules, apresenta uma personalidade bipartida alternando sua identidade entre um nobre senhor de terras e um selvagem; Hércules é humano e semideus, cultuado como salvador e protetor ${ }^{137}$. Essas características estão presentes em Tarzan que "não é somente a consciência da África, seu legislador, seu salvador, seu guarda-caça. Ele é, também, o policial, o grande juiz, o carrasco" (LACASSIN, 1971, p. 123) ${ }^{138}$. Como Hércules com seus doze trabalhos (Dodekathlos), Tarzan, a cada livro, cumpre sua missão de dominar feras e punir humanos faltosos e salvar inocentes por meio de seu imponente físico quase nu, à exceção de uma tanga de pele de felino. A possível evocação do herói grego, habitante do imaginário coletivo ocidental, na ilustração da capa dos livros de Tarzan cria uma antecipação no leitor com relação ao homem-macaco. Sabendo que ele sempre sairá vencedor, a curiosidade do leitor recai sobre o como e onde, pondo em relevo o cenário e a ação.

Além da ilustração, as capas das obras que formam o corpus deste estudo - $O$ tesouro de Tarzan, Tarzan o terrível e Tarzan o rei da jângal - apresentam indicações autorais e editoriais. Elemento de primeiro contato da obra com o público, os peritextos expõem de maneira implícita e explícita a condição de tradução e configuram um novo

\footnotetext{
${ }^{137}$ Sobre Hércules, fonte: Encyclopaedia Britannica. vol 11. p. 481, 1960.

${ }^{138}$ Tarzan n'est pas seulemant la conscience de l'Afrique, son législateur, son saveuteur, son garde-chasse. Il en est aussi gendarme, le grand juge, le bourreau.
} 
espaço que, pertencente agora ao editor detentor dos direitos sobre o livro, está relacionado à mudança do contexto de recepção.

Nos três livros de Tarzan, aqui analisados, o único elemento que permanece inalterado é o nome do autor, que se apresenta circunscrito nos peritextos: capa, página de rosto, lombada e no miolo do livro no alto da página ao lado do título. Na capa o escritor "assina" o texto e a dimensão de sua importância pode variar segundo a sua notoriedade. No caso de Edgar Rice Burroughs, sua fama de escritor deve-se precisamente aos livros de Tarzan, mesmo que não tenham sido suas primeiras obras, e, no Brasil, ela ainda foi alavancada pelas transposições cinematográficas. A coexistência do nome de Burroughs com a dos tradutores na capa e na página de rosto, num indício da proeminência dada a eles, implica autoria dividida. Já no miolo do livro o tradutor é ignorado e o nome do autor, no topo da página esquerda, retoma o texto ao lado da reprodução do título traduzido na página oposta, a da direita.

A presença, ou ausência, do nome do tradutor na capa é muito significativa, pois revela o seu status na cultura receptora, e pode definir a tradução como ato de criação ou como atividade ancilar. Certamente, não somente a localização do nome tradutor, mas também o destaque dado a ele e sua relação com o nome do autor denotam o seu prestígio, o qual pode ser usado para fins mercadológicos. No caso do corpus os nomes dos tradutores são conhecidos, em maior ou menor medida, no meio intelectual. Dos três tradutores aqui estudados, Monteiro Lobato já era um afamado escritor infantil e contista; Manuel Bandeira, apesar de poesia não ser uma expressão "popular", não se distanciou da vida mundana e foi até jurado em concurso de miss. O menos conspícuo foi Rangel que muito cedo se embrenhou no interior de Minas, todavia, parece ter sido um tradutor bastante conceituado na editora, não somente pelo número de traduções realizadas, mas também pelo fato de seu nome constar na capa como revisor da tradução e de não ser mencionado o nome do tradutor: 


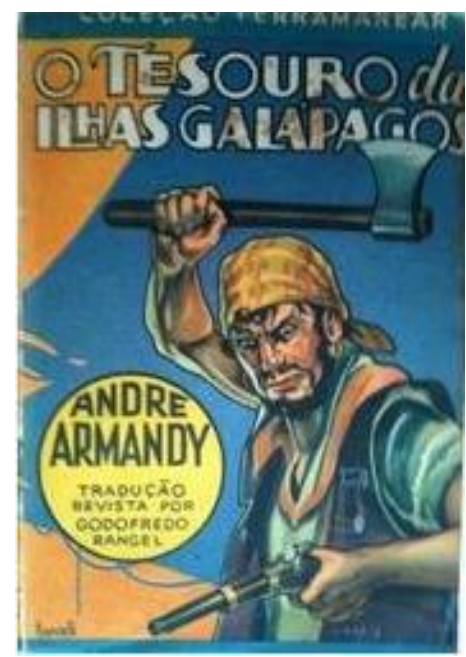

Figura 21: Capa com nome do revisor ${ }^{139}$

Tudo leva a crer, que com relação às histórias de Tarzan, o nome dos tradutores na capa chancela a qualidade da obra, no entanto, o destaque e a posição que ocupam não são padronizados. O nome de Monteiro Lobato ganha destaque especial por estar logo abaixo do nome do autor sobre uma faixa de fundo amarelo e em fonte maior que a dos outros nomes de tradutores. Se o destaque e a localização dos nomes do autor e tradutor implicam relativa equiparação, ela se limita à capa e à página de rosto, uma vez que na lombada e no miolo do livro o nome do tradutor é dispensado, em favor daquele do autor, mesmo do texto em português.

É na capa que se inicia o "processo de desterritorialização" (E. Vieira, 1982, p. 149) com a tradução do título, a substituição do nome da editora, a inclusão do nome da coleção, seguindo a padronização da publicação. Duas faixas horizontais azuis emolduram a capa: a superior estampando em letras brancas capitalizadas: "COLEÇÃO TERRAMAREAR" e a inferior "COMPANHIA EDITORA NACIONAL".

A lombada traz no alto a identificação do autor - E. R. Burroughs -, no meio o título do livro encimando uma pequena figura, um recorte do tema da capa; por fim, na parte inferior, o nome da editora. Assim como a capa, a lombada insinua a referência dividida entre original e tradução: o nome do autor inalterado e o título traduzido, mas note-se que não o nome do tradutor.

\footnotetext{
${ }^{139} \mathrm{https}: / / \mathrm{www}$. google.com.br/search?q=cole\%C3\%A7\%C3\%A3o+terramarear\&biw=1280\&bih=601\&tb $\mathrm{m}=\mathrm{isch} \& \mathrm{tbo}=\mathrm{u} \&$ source $=$ univ \&sa $=\mathrm{X} \& \mathrm{ei}=6 \mathrm{LMmVIDCENSNNob8gcgB \& ved}=0 \mathrm{CCsQ} 7 \mathrm{Ak}$
} 
Ainda na lombada, o nome da editora estabelece, também, essa passagem de uma origem à outra. Esse espaço exíguo tem uma importância estratégica, pois o livro pode ser imediatamente identificado na estante.

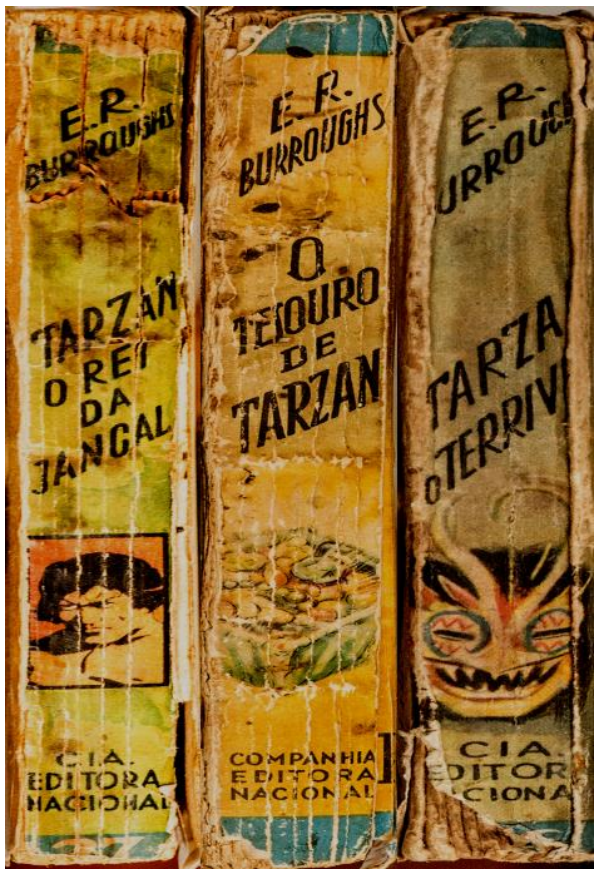

Figura 22: Lombadas dos livros do corpus ${ }^{140}$

Dentre as mudanças dos elementos textuais no revestimento do livro que indicam tratar-se de uma tradução, acha-se a questão do título. Como o nome do autor, o aparato titular é presença constante no livro, impresso na capa, no falso rosto, na página de rosto, na lombada e no lado esquerdo do alto das páginas. Se a função do título é a identificação da obra e indicação do conteúdo, sua intenção é de seduzir o leitor, assim a tradução do título não está sujeita somente às imposições linguísticas.

$\mathrm{O}$ autor, via de regra, tem autonomia para criar o título que julga mais adequado ao conteúdo da obra; o tradutor, no entanto, pode sofrer nessa escolha interferência da casa editora devido a questões mercadológicas e a não ser necessariamente o seu produtor de fato. De qualquer maneira, o editor torna-se responsável pelo título quando da publicação, que irá se vincular ao catálogo, epitexto puramente editorial.

Diferentemente das ilustrações das capas que são alusivas, sugestivas e convidativas, os títulos dos livros de Tarzan revelam-se insípidos pela sua literalidade. Essa obviedade tem um caráter identificador forte para o leitor, que sabe de antemão

\footnotetext{
${ }^{140}$ Acervo pessoal da autora.
} 
qual o tipo de leitura: "O onimato do herói anuncia nitidamente o regime da narrativa de uma aventura protagonizada por ele" (GENETTE, 2009, p. 277). Os elementos constitutivos do título têm como tema, na maioria das obras, o nome do protagonista, seguido do rema de ordem qualificativa - Tarzan, o filho das selvas, Tarzan, o rei da jângal - e epítetos pospostos ao nome Tarzan, que, além de serem facilmente confundíveis entre si - o indomável, o terrível, o invencível, o magnífico -, não dão indícios da história que está por vir, a não ser do incontestável poder da personagem.

Nos livros analisados, os títulos, visualmente, apresentam o mesmo destaque e localização dos títulos dos originais e apenas diferem um pouco com relação à fonte. Quanto ao conteúdo semântico, observam-se mudanças em maior ou menor grau. Em $O$ tesouro de Tarzan, que em inglês é Tarzan and the jewels of Opar, o impacto do nome Tarzan é amenizado pelo deslocamento da posição temática para a remática. Também, a ausência do nome "Opar", que consta no título em inglês, elimina a expectativa do leitor, pois o nome insinua exotismo, com uma aura de mistério, uma vez que não dá ao leitor indicação se seria um lugar ou uma pessoa, homem ou mulher. Quanto ao léxico, nota-se a adoção do hiperônimo "tesouro" em detrimento do hipônimo jewels, que pode ser tanto "jóia" quanto "gema".

As pedras preciosas, retiradas por Tarzan da cidade mítica de Opar serão o fio condutor do desenrolar da aventura, provocando cobiça e violência. entretanto, Tarzan não é o dono do tesouro, como o título em português sugere, e se apossa dele, como um ladrão qualquer, e assim se justifica, para não comprometer sua nobreza:

- Não ha outro recurso tão facil para obter outra fortuna como voltar aos tesouros das cavernas de Opar e traze-los para cá - retrucou ele. - Terei muito cuidado, Jane, e ha toda a probabilidade de que os habitantes de Opar não saibam nunca ter eu estado ali e carregado com outra porção do tesouro, cuja existencia aliás ignoram e de cujo valor não fariam, de resto, a menor ideia (p. 13).

There is no other way half so easy to obtain another fortune, as to go to the treasure vaults of Opar and bring it away," he replied. "I shall be very careful, Jane, and the chances are that the inhabitants of Opar will never know that I have been there again and despoiled them of another portion of the treasure, the very existence of which they are as ignorant of as they would be of its value.

Enfim, parece que o título, O tesouro de Tarzan, é mais apelativo ao leitor brasileiro que Tarzan e as pedras preciosas de Opar, principalmente porque o termo "tsouro" já se encontra no imaginário do leitor remetendo a outras publicações da mesma coleção, populares no período, como A Ilha do tesouro, de Robert Louis 
Stevenson, e $O$ tesouro das ilhas Galápagos, de André Armandy, cuja ação envolve disputa e busca por tesouro.

A respeito do título do outro livro, Tarzan, o rei da jângal, do inglês Tarzan, lord of the jungle", observa-se a mudança de lord para "rei" e a manutenção de "jângal". O vocábulo "jângal", proveniente da Índia portuguesa, já era dicionarizado na época contudo, não é uma escolha unânime entre os outros tradutores, que optam outros termos do mesmo campo semântico, como poderá ser constatado na análise textuais a seguir, como por exemplo Álvaro Eston no primeiro volume da série: Tarzan, o filho das selvas (Lord of the Apes). A questão da tradução desse termo será melhor discutida na análise do corpus.

O outro ponto a analisar é o jogo entre as duas acepções de lord, que "rei" não reproduz: a do título nobiliário herdado, Greystoke, e a de domínio. Tarzan, em diversas ocasiões demonstra dar menos importância ao título herdado, Lord Greystoke, que ao conquistado "rei dos macacos". Passando de lord of the jungle para "rei das selvas", ele tem seu poder ampliado na soberania sobre a floresta e todos que nela habitam tornamse seus súditos, contando até mesmo com uma guarda pretoriana, os fiéis Waziris. O título paródico remete, em português, à designação tradicionalmente reservada ao leão e agora usurpada por Tarzan. Interessante notar que, Rangel, apesar de ter substituído lord por "rei" no título, ele mantém a designação nobiliárquica no capítulo 19: "Lord Tarzan".

O tradução do título do terceiro livro analisado, Tarzan the terrible, não apresenta nenhuma peculiaridade. Agenor Soares dos Santos (1983, p. 470) chama atenção para o vocábulo "terrible", que classifica nas duas línguas de palavra-ônibus, ou seja, polissêmica. Tanto em inglês quanto em português o termo recebe conotações positivas ou negativas conforme o contexto. Neste caso parece referir-se às características extraordinárias e fora do comum do herói: imenso, colossal, implacável, invencível ${ }^{141}$, em português; formidable, redoubtable, awesome, awe-inspiring, em inglês ${ }^{142}$. O título reproduz o epíteto conferido a Tarzan por um povo primitivo que fala uma língua inventada por Burroughs:

Ta-den, então, que se colocara ao lado de Tarzan, desferiu um grito estridente: Jad-guru-don! Este é Tarzan, o Terrivel! Este é Tarzan, o Invencivel! (p. 31).

\footnotetext{
${ }^{141}$ Fonte: Dicionário Houaiss de sinônimos e antônimos.

${ }^{142}$ Fonte: J. I. RODALE. The synonym finder.
} 
And now Tarzan stood in the recess beside Ta-den. "Jad-guru-don!" repeated the latter, smiling - "The terrible man! Tarzan the Terrible! They may kill you, but they will never forget you".

Nesse trecho observa-se novamente a tendência de Lobato de "editar" o texto, resumindo em uma palavra última colocação de Ta-den: - They may kill you, but they will never forget you. No original, Tarzan e definido como inesquecível e não invencível.

O título tem uma conotação de ordem histórica evocando o czar russo do século 16, Ivan IV, o terrível. Esse monarca, mesmo tendo sido o responsável pelo desenvolvimento da Rússia, fazendo-a passar do medievalismo ao império, e sendo descrito em diversas fontes como inteligente, estrategista, piedoso, por sua personalidade complexa e instável ficou, conhecido popularmente como um tirano cruel, assassino do próprio filho e, por isso a alcunha adquire nesse caso mais conotações pejorativas que positivas.

Concluindo a questão dos títulos, neles já se manifesta uma das características da literatura de massa: os clichês e os lugares comuns, opondo-se à concepção de obra canônica de originalidade e inovação, como apregoa Bloom (1995). O aparato titular a partir de referências a códigos já conhecidos do repertório ocidental "indica" o conteúdo da obra. Neste caso, o leitor terá sua expectativa confirmada, inversamente ao que acontece na leitura da obra canônica que, ainda segundo Bloom, provoca estranhamento. O conhecido acarreta a sensação de segurança no público leitor que não busca nessa literatura renovação estética, mas simplesmente entretenimento, algo que não desafie sua capacidade interpretativa.

Concluindo, o título traduzido recebe novo destinador, cuja transposição linguística está vinculada à mudança do destinatário e pode estar sujeito à interferência do editor. O título do livro depois de publicado passa a ser um identificador cujo motivo de escolha perde sua importância. Como o destinatário da obra traduzida não fica ciente se o aparato titular foi sujeito a modificações impostas por motivos terceiros, as eventuais críticas recaem sobre o tradutor.

Ainda como parte do revestimento do livro, a contracapa e as orelhas podem se destinar a fins gerais da editora, podem conter dados bibliográficos do autor ou referirse ao texto (HOUAISS, 1967, p. 52-53). No caso dos livros de Tarzan, a orelha e a contracapa são espaços puramente comerciais e, diferentemente do que ocorre em muitas publicações de literatura, não se ocupam de apresentar a obra e tampouco o 
autor, mas seguem a lógica editorial de que a cultura é um produto a ser comercializado, uma vez que existe um mercado consumidor. Essas partes do livro que compõem o seu peritexto, nesse caso tornam-se epitextos, quando pensadas em sua relação com o que está sendo anunciado.

As contracapas, por exemplo, tanto divulgam títulos da mesma coleção (Figura 25), já publicados, ou a publicar, como promovem outra coleção (Figura 26) da mesma casa editorial e estabelecem claramente o tipo de literatura e de público. Entretanto, apesar de se tratarem de histórias somente com intuito de entreter os jovens, a editora advoga o zelo com que foram selecionados, que é avalizado pela citação de Monteiro Lobato: "Dar aos meninos bons livros adequados á idade é o melhor meio de formar homem".

As orelhas (Figuras 27 e 28) fazem propaganda de obras de Monteiro Lobato que, apesar de não ser mais sócio da editora no período, gozava de grande prestígio como escritor infantil e tradutor.

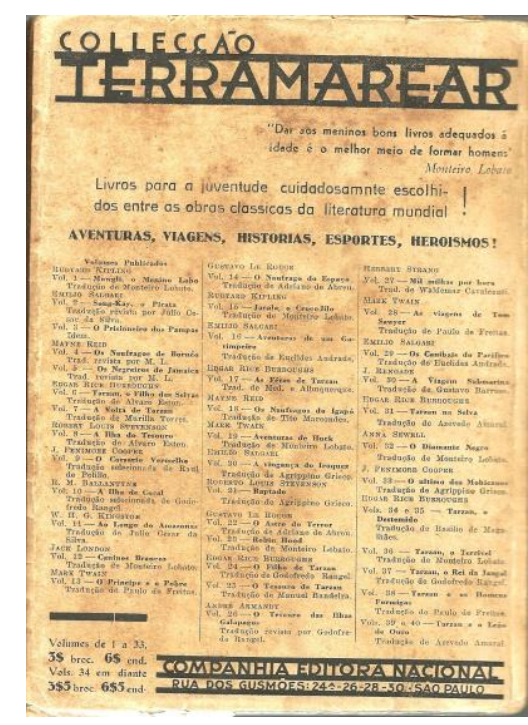

Figura 23: contracapa

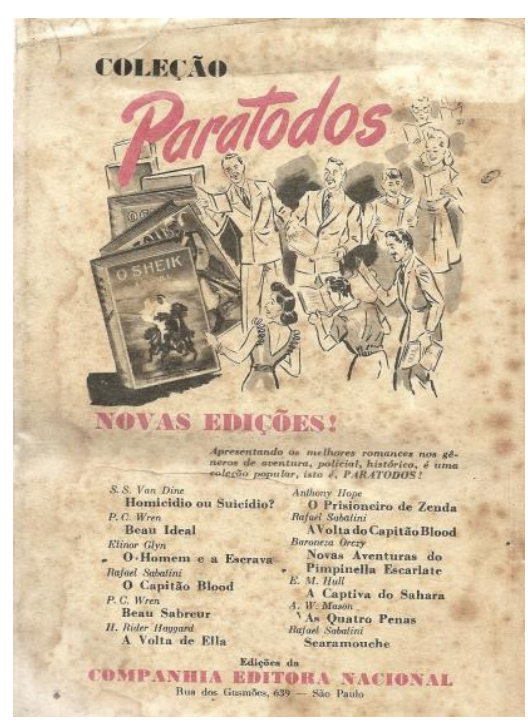

Figura 24: contracapa ${ }^{143}$

\footnotetext{
143 Acervo pessoal da autora.
} 


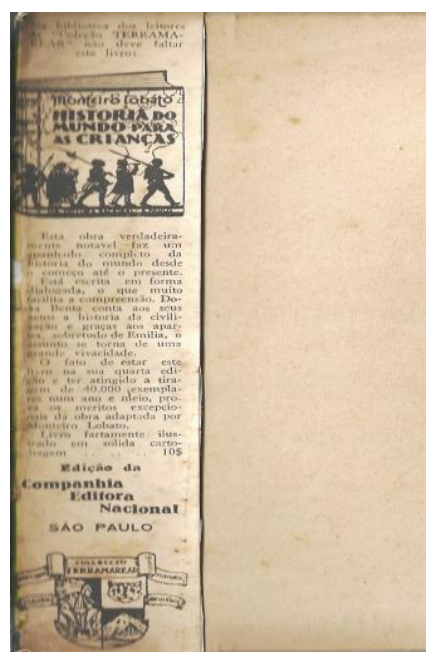

Figura 25: orelha

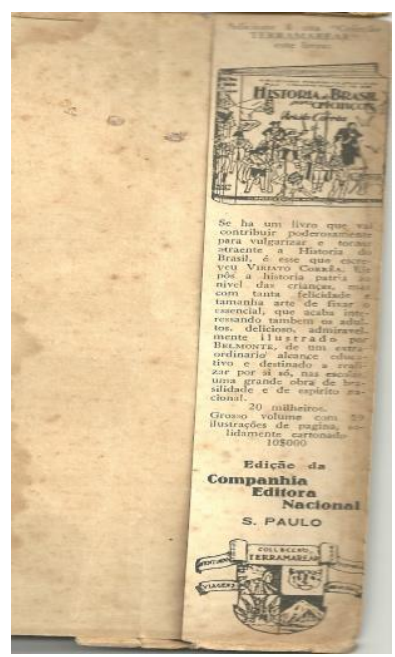

Figura 26: orelha

O verso da capa (Figura 29) e da contracapa (Figura 30) promovem ainda o lançamento de revistas e de Tarzan em quadrinhos.

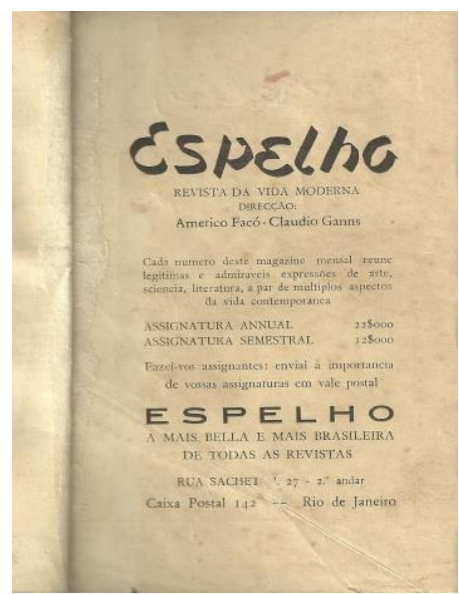

Figura 27: verso da capa

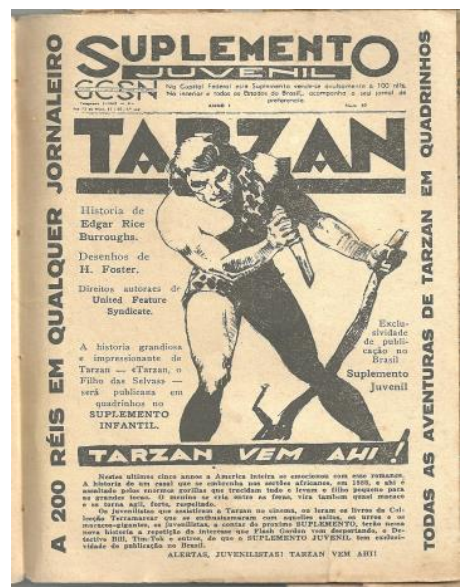

Figura 28: verso da contracapa ${ }^{144}$

\subsubsection{O miolo do livro}

Sempre seguindo a normalização editorial no que concerne à nomenclatura tradicional, descrita por Houaiss (1967), a análise prosseguirá passando do revestimento do livro para o seu interior, ou seja, o miolo de livro, formado por uma sucessão de folhas que se inicia com peritextos que precedem o texto literário, propriamente dito e que são o falso rosto, o rosto e o índice.

\footnotetext{
${ }^{144}$ Acervo pessoal da autora.
} 
O falso rosto (ou ante-rosto), primeira página impressa, apresenta única e exclusivamente o título da obra e os indícios de tradução são ocultados. O título traduzido confirma novamente a mudança do contexto de recepção já estabelecida na capa, cuja autoridade do original é abalada não somente pela transposição linguística, mas também por eventuais modificações. Se nomear é fazer existir, "renomear é criar novos interpretantes para a obra é imprimir um novo rumo à sua existência continuada" (VIEIRA, 1992, p. 151).

Do falso rosto para o rosto a condição de tradução novamente torna-se explícita. Essa segunda página impressa repete as informações da capa, mais a imprenta com a data, a cidade e o ano de publicação brasileira e a declaração dos direitos de tradução, transferindo a autoridade plena do original para a nova obra e criando para ela uma nova trajetória na cultura receptora.

O verso da folha de rosto, como uma certidão de nascimento, retoma a dupla naturalidade da obra ao revelar o nome "do original em inglês" e reafirma ser a tradução de "propriedade literária da C.E.N de São Paulo".

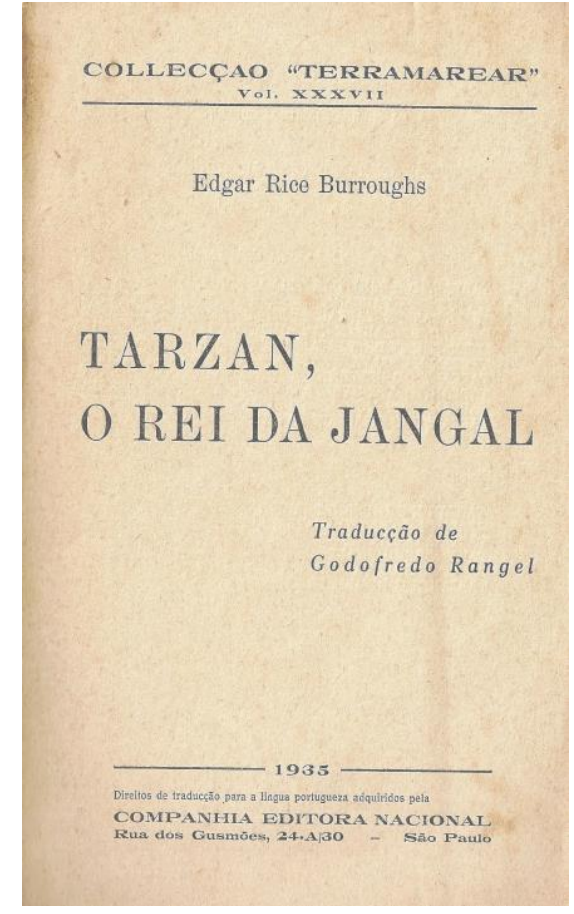

Figura 29: Ante-rosto

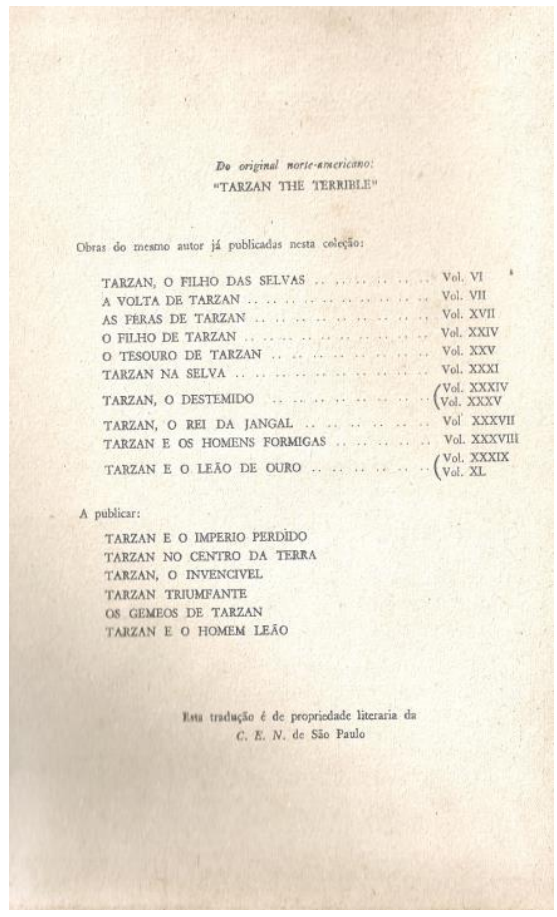

Figura 30: Verso do ante-rosto ${ }^{145}$

\footnotetext{
145 Acervo pessoal da autora.
} 
Com a omissão de vários dados que frequentemente constam no verso do rosto e que revelariam a vinculação do livro com seu original, como o nome de Edgar Rice Burroughs, a editora americana McClurg, o local e a data da publicação do original, inicia-se o processo de desterritorialização que fará com que o leitor comece a perceber a obra traduzida como se fosse original. O editor passa a ser o detentor dos desígnios da obra influenciado pelo contexto de recepção e ao mesmo tempo exercendo influência sobre ele.

Se no revestimento do livro, que se constitui da capa, rosto, ante-rosto e orelhas, o espaço é ocupado por questões editoriais, no miolo o autor é soberano, e no caso da tradução essa condição é dividida com o tradutor. Por mais que se advogue o caráter autoral da tradução, ela ainda se acha associada a um texto de partida e ao contexto de recepção. Esse vínculo é determinado pelo editor que exerce o controle sobre a recepção ao selecionar o texto a ser traduzido e decidirá sobre a inclusão de um prefácio, ou posfácio, e de notas do tradutor.

A presença desses recursos pode significar tanto a proeminência do tradutor, quanto a atenção aos futuros leitores, dando-lhes a conhecer não somente a obra, como as escolhas e estratégias tradutórias, conforme analisa Else Vieira (1992, p. 161): "Se a palavra do editor e a do tradutor vêm primeiro, ela criará interpretantes que estruturarão a futura recepção e a leitura da obra, passando, assim, a direcionar a Fortleben do livro traduzido em seu novo contexto".

Quando um determinado escritor goza de reconhecimento crítico, o prefácio valoriza obra e autor; todavia, no caso dos livros de Tarzan, os tradutores gozavam de maior prestígio do que Burroughs e suas produções literárias eram mais consideradas do que o tipo de literatura que o escritor americano produzia. Isso pode ser um dos fatores que nortearam as escolhas feitas pelo tradutor, pois, conforme observa Paulo Henriques Britto: "O reconhecimento crítico da excelência de um determinado escritor implica sempre a valorização de seu estilo, das peculiaridades de sua linguagem que o singularizaram" (2013, p. 64).

Se o discurso produzido sobre o próprio texto, preliminar, pós-liminar ou no pé de página, pode expor a condição de tradução, a ausência desses peritextos, também, pode ter um significado importante com relação à sua recepção. Os três livros de Tarzan aqui analisados não apresentam nenhum tipo desses recursos que explicitam a presença discursiva do tradutor. Presume-se que o público alvo desse tipo de leitura, 
frequentemente, por desconhecer a língua original da obra toma a tradução por "original" e pode prescindir do didatismo de um prefácio. Ainda levando em conta o público alvo, pretensamente com menos sofisticação intelectual, as notas explicativas poderiam, em vez de contribuir para o entendimento, prejudicar o andamento da leitura.

No caso do romance de aventura, como o objetivo é entreter contando uma história, o tradutor poderia pensar em não intervir no texto de tal maneira que impeça o leitor de sentir que leu o "original", assim o único elemento que poderia solapar a "ilusão de transparência" e de "coincidência" (HERMANS, 1996) entre o discurso autoral e o traduzido seria o nome do tradutor na capa e na folha de rosto.

\subsubsection{Os intertítulos: anunciadores da narrativa}

Os intertítulos, ou subtítulos, ocupam uma posição limiar entre peritexto e texto, pois a primeira aparição se dá no índice, que se localizam depois da folha de rosto e antes do texto, e, posteriormente, no espaço textual identificando cada capítulo. O índice, ou sumário, é o levantamento fiel do aparato intertitular e é uma indicação cômoda para a leitura, oferecendo uma visão prospectiva do conteúdo. Segundo Houaiss (1967, p. 142):

[O índice] constitui um encaminhamento lógico e ideológico para situar o leitor na substância presumível da matéria nesse local versada - e, quando não consegue isso a priori, faz-se uma indicação de situação a posteriori para quem já tenha uma vez lido ou compulsado a obra.

Os intertítulos, além da função indicar o conteúdo, também servem para fracionar a narrativa, assim, "a relação entre texto e paratexto (a enunciação intertitular) diz respeito à estrutura da obra e de sua evolução" (GENETTE, 2009, p. 277). A organização do livro em episódios curtos e subtitulados, segundo a sequência dos acontecimentos, facilita a leitura, que pode ser pausada segundo a capacidade de atenção do leitor, supostamente menos competente, no caso. O seccionamento nos livros de Tarzan são mais ou menos equilibrados quantitativamente: $O$ tesouro de Tarzan: 24 capítulos; Tarzan, o terrível: 25; Tarzan o rei da jângal: 24. Cada capítulo tem de sete a dez páginas cada em extensão.

Quanto à formatação, a subtitulação segue a tradição do romance com o intertítulo temático precedido de "menção remática", capítulo número tal, destacando a cronologia. Os temas dos subtítulos nos três livros aqui estudados são bastante 
explícitos, sem ambiguidades ou jogos de palavras, e adiantam claramente ao leitor o conteúdo do episódio, em concordância com as características da literatura de entretenimento. Mesmo não oferecendo obstáculos à tradução, vale observar algumas escolhas feitas pelos tradutores, principalmente no nível léxico-semântico.

Para os subtítulos dos capítulos 11 e 19, de O tesouro de Tarzan, Bandeira opta por diferentes correspondentes para o mesmo termo em inglês, beast: "Tarzan vira bicho outra vez" (Tarzan becomes beast again) e "Jane Clayton e as feras da mata" (Jane Clayton and the beasts of the jungle). No primeiro caso, como em português "virar fera" pode significar ficar muito bravo, o emprego de "bicho" coloca o foco na identidade cindida do herói entre homem civilizado e homem selvagem. Já no segundo intertítulo, "feras" sugere o perigo que há na selva a que está sujeita a heroína.

Nesse último intertítulo, também, a escolha de outros termos correspondentes se dá com relação a jungle, que Bandeira, além de não adotar nenhuma vez o correspondente "jângal" em toda narrativa, não mantém regularidade variando os sinônimos: capítulo 3: "O apelo da mata" (The call of the jungle) e capítulo 21: "A fuga para a floresta" (The flight to the jungle). Monteiro Lobato, em Tarzan, o terrível, por sua vez, mantém a correspondência do termo no capítulo 7: "Astúcias da jangal" (Jungle craft) e no capítulo 19: "A Diana da jangal" ${ }^{146}$ (Diana of the jungle).

Burroughs nomeia o último capítulo de dois livros, $O$ tesouro de Tarzan e Tarzan, o terrivel, com uma só palavra que resume o final das aventuras vividas pelo protagonista e seu retorno ao lar: Home. Bandeira opta por uma explicitação da ideia com "Volta ao lar" e Lobato usa uma a expressão neutra: "Epílogo", não antecipando ao leitor o retorno do herói selvagem à sua condição de homem civilizado. Outra liberdade tomada por Lobato na tradução dos intertítulos é a do capítulo 20: "A noite silente" (Silently in the night), quando transforma o advérbio em adjetivo, qualificando "noite". Entretanto, o episódio narra a fuga silenciosa de Tarzan da jaula em que se achava preso noite adentro e não a descrição da noite.

Acréscimos em tradução são muitas vezes necessários se quisermos exprimir com exatidão o conteúdo semântico do enunciado ou, simplesmente, de um vocábulo. No caso dos intertítulos aqui analisados, a complementação parece não ter relevância. Em Tarzan o terrível, o capítulo 2: To the Death! descreve uma disputa pela chefia da tribo. Lobato traduz como "Para a vida e para a morte", remetendo à expressão fixa 
"luta de vida ou morte". Em Tarzan, o rei da jângal, acréscimo também faz Rangel, em que no entanto, na maioria das traduções dos subtítulos procura manter uma correspondência, no capítulo 7: "A cruz de pedra" (The cross). O episódio narra o encontro de uma personagem com uma cruz no meio da selva:

Andou cerca de meia legua por ella acima, sem descobrir signaes de habitação humana; mas, a uma volta do caminho, viu-se ao pé de uma cruz branca e musgosa de enormes proporções; toda de pedra, ella se erguia bem no meio do caminho até á altura de uns vinte metros (p. 64).

He had covered something like three miles without having discovered any sign of habitation when, at a turn in the path, he found himself at the foot of a great white cross of enormous proportions. Hewn from limestone, it stood directly in the center of the trail and towered above him fully sixty feet.

Ao complementar a informação contida no subtítulo, o tradutor parece querer suscitar no leitor a curiosidade pela estranheza de se encontrar uma cruz de pedra tão fora de contexto selvagem.

No mesmo livro, no subtítulo do capítulo 13: "A barraca de Zeyt" (In the beyt of Zeid), Rangel "facilita" a leitura ao não usar o vocábulo que significa casa em algumas línguas semíticas, inglês esta quase restrita ao contexto religioso. No Oxford English Dictionary o vocábulo está grafado Beth e associado a Din, significando a corte judaica (bèth: house, dīn: judgement).

Dois subtítulos de diferentes livros apresentam uma dupla referência, no texto e exterior a ele. Um deles está em Tarzan, o terrível, no subtítulo do capítulo 15: The king is dead. Esse subtítulo remete externamente à histórica expressão, Le roi est mort, vive le roi, anúncio da morte do soberano e sua imediata sucessão, e internamente a este episódio:

'Ko-tan já não existe! Mo-sar é rei! Que os guerreiros fieis ao glorioso passado de Pal-ul-don defendam seu novo soberano! (p. 126).

"Ko-tan is dead!" he cried. "Mo-sar is king! Let the loyal warriors of Pal-ul-don protect their ruler!"

Lobato, no caso do subtítulo desse capítulo, acrescenta na tradução a segunda parte da tradicional locução, que se acha implícita no original, adotando a expressão conhecida: "Rei morto, rei posto".

O outro subtítulo que também apresenta dupla referência se acha em Tarzan, $o$ rei da jângal no capítulo 12: "Tomorrow Thou Diest!". As aspas já indicam tratar-se de citação. De fato, o subtítulo joga com a intertextualidade da fala de Isabella a Claudio 
na primeira cena do terceiro ato da peça Measure for measure, de Shakespeare: "Yes, he would give't thee, from this rank offence, so to offend him still. This night's the time that I should do what I abhor to name, or else thou diest to-morrow". Por envolver também a questão do ciúme por uma mulher, nesse episódio do livro de Tarzan, Burroughs toma emprestado a frase de Shakespeare, que Rangel traduz por "Amanhã você morrerá", mantendo as aspas, mas tornando-a menos literária que a utilizada por Burroughs ao adotar o pronome "você".

A opção por "você" não estabelece relação de intimidade como "tu" e nem de respeito como "senhor(a)" e parece ser a intenção do tradutor dar a impressão de que se trata de um diálogo "real". O problema reside na ausência de uma regra geral no português do Brasil sobre o uso dos pronomes e formas de tratamento que indiquem a posição da personagem no seu meio e a hierarquia perante seu interlocutor.

Em inglês, o pronome you, e o arcaico thou, não denuncia a condição social, tampouco o gênero obrigando escolhas por parte do tradutor. Em Tarzan o rei da jângal, no subtítulo "Amo-o" (I love you), do capítulo 20, o tradutor, Godofredo Rangel, opta pela fala da mulher. No decorrer do episódio o homem e a mulher se declaram (p. 182), mas o tradutor provavelmente se baseia no fato de o homem já ter revelado seu amor anteriormente na história, pondo em ênfase a atitude da princesa.

- Eu amo-a! amo-a, Guinalda! - exclamou Blake.

"I love you! I love you, Guinalda!" cried Blake.

[...] ella proferiu três palavras que para elle significavam mais do que, juntas, todas as linguas do mundo: -Eu amo-o!

[...] she called back through the falling night three words that meant more to him than all the languages of all the world combined: "I love you!"

Quanto à forma de tratamento, o tradutor adota a forma de respeito senhor/senhora:

- Que o senhor se gabara de que queria fazer que eu o amasse, somente para depois desprezar-me (p. 182).

- Amo-a - segredou Blake tão baixo, que mais ninguém, excepto ella, poderia ouvir (p. 148).

Decorre daí a escolha da pessoa gramatical do pronome pessoal da terceira pessoa, com a posição enclítica, seguindo a posição considerada normal pela gramática normativa (CUNHA, 1980, P. 307). Entretanto, o emprego átono objeto direto "o" e "a" 
de nível culto, apresenta registro formal destoante da oralidade do discurso direto. A distância entre o registro escrito e o falado no português do Brasil é maior do que no inglês e a consequência é um diálogo artificial. A linguagem coloquial dá preferência a "amo-lhe", pronome do objeto indireto aqui na função de direto, quando a forma de tratamento adota é a da terceira pessoa, mesmo no caso do uso do deferencial "senhor(a)" ${ }^{147}$. Além disso, ao adotar o pronome da terceira pessoa "o" e "a" pode gerar ambiguidade por referir-se tanto ao interlocutor como a outra pessoa não participante do diálogo.

Em $O$ tesouro de Tarzan, apesar de a história apontar não haver intimidade entre os protagonistas do diálogo, o tradutor Bandeira adota o pronome da segunda pessoa para a mesma oração, I love you, acentuando o coloquialismo:

- Não me deixes! gritou. - Fica e serás o Grão-Sacerdote. La ama-te. toda Opar será tua. Serás servido por escravos. Fica, Tarzan e deixe que o meu amor te recompense (p. 49).

"Do not leave me!" she cried. "Stay, and you shall be High Priest. La loves you. All Opar shall be yours. Slaves shall wait upon you. Stay, Tarzan of the Apes, and let love reward you".

- Não posso amar-te, La - disse Tarzan em voz baixa (p. 89).

"I cannot love you, La," said Tarzan in a low voice.

Concluindo, diferentemente do título, que tem a função de anunciar globalmente o texto e seduzir um leitor em potencial, os intertítulos, ou subtítulos, por serem internos ao texto servem para "organizar" cronologicamente a leitura em curso, dividindo-a em episódios. No caso dos livros Tarzan, enquanto literatura de entretenimento, os intertítulos são objetivos e curtos, e, salvo os dois últimos exemplos, referem-se exclusivamente ao texto, não oferecendo, em teoria, muitas possibilidades interpretativas por parte dos tradutores. Entretanto, conforme analisado acima, alguns tradutores fazem escolhas que podem ter sido influenciadas pela percepção que se tem do público alvo.

\subsection{As traduções das obras do corpus}

\subsubsection{Um trabalho de editoração}

\footnotetext{
${ }^{147} C f$. Celso LUFT, p. 52.
} 
Partindo do pressuposto de que toda atividade tradutória envolve um trabalho de reescrita, verificam-se nas traduções de Tarzan do corpus diferentes graus de manipulação textual. $\mathrm{O}$ tradutor intervém no texto por meio não só da recomposição do léxico, do campo semântico, da sintaxe, como também da estruturação textual. Omissões, acréscimos, compensações, glosas e paráfrases são alguns recursos inerentes à operação tradutória e estão relacionados ao trabalho do tradutor; a condensação, por sua vez, estaria sujeita primordialmente às exigências editoriais e aí se aproxima da editoração.

Segundo a análise de John Milton (2002, p. 91) as obras que são traduzidas para se encaixarem em determinados mercados levam em conta os custos de produção fazendo "com que o livro obedeça a certo número de páginas". Assim, os livros da coleção Terramarear, da qual fazem parte as histórias de Tarzan, sofrem uma redução textual, criando homogeneidade nas dimensões dos volumes, o que concorre para o barateamento dos custos de produção para atingir todo tipo de público.

Em geral, no que se refere à tradução, o texto em português é mais longo que o texto em inglês, muito devido ao poder de concisão desta língua, todavia, no caso do corpus deste estudo, observa-se justamente o oposto, sendo o número de palavras das traduções inferior àquele dos originais ${ }^{148}$ :

\begin{tabular}{|c|c|c|c|}
\hline & $\begin{array}{c}\text { O tesouro de Tarzan } \\
\text { (Trad. Bandeira) }\end{array}$ & $\begin{array}{c}\text { Tarzan, o terrível } \\
\text { (Trad. Lobato) }\end{array}$ & $\begin{array}{c}\text { Tarzan, o rei da jângal } \\
\text { (Trad. Rangel) }\end{array}$ \\
\hline Inglês & 66.085 & 94.025 & 69.935 \\
\hline Português & 58.484 & 49.679 & 66.728 \\
\hline
\end{tabular}

Tabela 5: Comparação do número de palavras entre originais e traduções.

A maior discrepância entre a extensão do texto inglês e a do português se encontra na tradução de Monteiro Lobato, com redução de aproximadamente $47 \%$. Mesmo que se considere que o original Tarzan, the terrible, conta com um número de palavras entre $25 \%$ e $30 \%$ superior aos outros dois originais, Tarzan, the lord of the jungle e Tarzan, and jewels of Opar, e que o volume está sujeito à padronização

\footnotetext{
${ }^{148}$ Esses números não são acurados, pois foram calculados a partir dos textos digitalizados e o fato de se tratarem de livros muito antigos prejudica o processo de leitura do aparelho. Contudo, pode-se ter uma ideia aproximada da diferença.
} 
imposta pela coleção, a tradução de Lobato conta com um número de palavras muito inferior aos dos outros dois títulos, levando a crer que outro fator que possa ter contribuído para esse corte drástico seria a ideia do famoso autor de deixar a leitura mais "fluente" e "com o mínimo possível de literatura" (LOBATO, 1957b, p. 339).

$\mathrm{Na}$ maior parte do texto, Lobato cumpre a cronologia dos acontecimentos, mantém todas as personagens e a correspondência nos diálogos, mas suprime as longas descrições, como se pode ver nesta comparação de parágrafo por parágrafo do início do Capítulo $3^{149}$ :

\section{Tarzan, o terrivel}

Tarzan, the terrible
Era Es-sat, o chefe. Correu os olhos em torno como para assegurar-se de que ninguém o observava; depois esgueirou-se para fora e deu de marinhar pela pedranceira acima. Não havia nenhum milagre naquilo; a escarpa era escalonada de curtos espeques encravados na rocha viva, justamente para aquilo - para facilitar a ascenção dos seus moradores. Mas Es-sat ao subir tinha o cuidado de evitar as numerosas bocas, ou fendas, ou janelas que esfuracavam a superfície da pedra. Ficavam ali as cavernas dos Waz-dons, e cada abertura ia ter a um apartamento. Verdadeira colmeia de grandes alvéolos escavados na rocha.
Night had fallen upon unchartered Pal-ul-don. A slender moon, low in the west, bathed the white faces of the chalk cliffs presented to her, in a mellow, unearthly glow. Black were the shadows in Kor-ul-JA, Gorge-of-lions, where dwelt the tribe of the same name under Es-sat, their chief. From an aperture near the summit of the lofty escarpment a hairy figure emerged - the head and shoulders first - and fierce eyes scanned the cliff side in every direction.

It was Es-sat, the chief. To right and left and below he looked as though to assure himself that he was unobserved, but no other figure moved upon the cliff face, nor did another hairy body protrude from any of the numerous cave mouths from the high-flung abode of the chief to the habitations of the more lowly members of the tribe nearer the cliff's base. Then he moved outward upon the sheer face of the white chalk wall. In the half-light of the baby moon it appeared that the heavy, shaggy black figure moved across the face of the perpendicular wall in some miraculous manner, but closer examination would have revealed stout pegs, as large around as a man's wrist protruding from holes in the cliff into which they were driven. Essat's four handlike members and his long, sinuous tail permitted him to move with consummate ease whither he chose-a gigantic rat upon a mighty wall. As he progressed upon his way he avoided the cave mouths, passing either above or below those that lay in his path.

The outward appearance of these caves was similar. An opening from eight to as much as twenty feet long by eight high and four to six feet deep was cut into the chalklike rock of the cliff, in the back of this large opening, which formed what might be described as the front veranda of the home, was an opening about three feet wide and six feet high, evidently forming the doorway to the interior apartment or apartments. On either side of this

\footnotetext{
${ }^{149}$ Mais uma vez vale ressaltar que a foi mantida a ortografia original das publicações em análise.
} 


\begin{tabular}{|c|c|}
\hline & $\begin{array}{l}\text { doorway were smaller openings which it were easy } \\
\text { to assume were windows through which light and } \\
\text { air might find their way to the inhabitants. Similar } \\
\text { windows were also dotted over the cliff face } \\
\text { between the entrance porches, suggesting that the } \\
\text { entire face of the cliff was honeycombed with } \\
\text { apartments. From many of these smaller apertures } \\
\text { small streams of water trickled down the } \\
\text { escarpment, and the walls above others was } \\
\text { blackened as by smoke. Where the water ran the } \\
\text { wall was eroded to a depth of from a few inches to } \\
\text { as much as a foot, suggesting that some of the tiny } \\
\text { streams had been trickling downward to the green } \\
\text { carpet of vegetation below for ages. } \\
\text { In this primeval setting the great pithecanthropus } \\
\text { aroused no jarring discord for he was as much a } \\
\text { part of it as the trees that grew upon the summit of } \\
\text { the cliff or those that hid their feet among the dank } \\
\text { ferns in the bottom of the gorge. }\end{array}$ \\
\hline $\begin{array}{l}\text { Rente a uma das tais aberturas Es-sat se deteve e } \\
\text { imóvel ficou a ouvir, na atitude do caçador- em } \\
\text { tocaia. Depois entrou, afastando a pesada cortina } \\
\text { de pele que a fechava. Um comodo espaçoso } \\
\text { apresentou-se aos seus olhos; ao fundo, um } \\
\text { corredor, donde vinha debil luz. Atravessado o } \\
\text { comodo, Es-sat se meteu pelo corredor, mas já } \\
\text { cauteloso, com a clava que trouxera a tiracolo em } \\
\text { punho. }\end{array}$ & $\begin{array}{l}\text { Now he paused before an entrance-way and } \\
\text { listened and then, noiselessly as the moonlight upon } \\
\text { the trickling waters, he merged with the shadows of } \\
\text { the outer porch. At the doorway leading into the } \\
\text { interior he paused again, listening, and then quietly } \\
\text { pushing aside the heavy skin that covered the } \\
\text { aperture he passed within a large chamber hewn } \\
\text { from the living rock. From the far end, through } \\
\text { another doorway, shone a light, dimly. Toward this } \\
\text { he crept with utmost stealth, his naked feet giving } \\
\text { forth no sound. The knotted club that had been } \\
\text { hanging at his back from a thong about his neck he } \\
\text { now removed and carried in his left hand. }\end{array}$ \\
\hline $\begin{array}{l}\text { Vinha a luz dum comodo que abria para esse } \\
\text { corredor e no qual, reclinada sobre peles } \\
\text { estendidas sobre um estrado de pedra, jazia uma } \\
\text { jovem Waz-don. Suas vestes repousavam num } \\
\text { rude coxim ao lado, juntamente com um peitoral } \\
\text { de ouro batido. Apesar de ter o corpo recoberto de } \\
\text { ptlagem negra, era uma criatura inegavelmente } \\
\text { formosa. Formosa pelo menos para Es-sat, cujos } \\
\text { olhos, ao ve-la, se arregalaram e cujo peito arfou. } \\
\text { Chocada pelo imprevisto da aparição a jovem } \\
\text { ergueu-se de jacto com o terror pânico impresso } \\
\text { na face. Colheu rapida as vestes de pele; escondeu } \\
\text { o corpo desnudo e ia a colocar o pesado peitoral } \\
\text { de ouro quando Es-sat se adiantou. }\end{array}$ & $\begin{array}{l}\text { Beyond the second doorway was a corridor } \\
\text { running parallel with the cliff face. In this corridor } \\
\text { were three more doorways, one at each end and a } \\
\text { third almost opposite that in which Es-sat stood. } \\
\text { The light was coming from an apartment at the end } \\
\text { of the corridor at his left. A sputtering flame rose } \\
\text { and fell in a small stone receptacle that stood upon } \\
\text { a table or bench of the same material, a monolithic } \\
\text { bench fashioned at the time the room was } \\
\text { excavated, rising massively from the floor, of which } \\
\text { it was a part. } \\
\text { In one corner of the room beyond the table had } \\
\text { been left a dais of stone about four feet wide and } \\
\text { eight feet long. Upon this were piled a foot or so of } \\
\text { softly tanned pelts from which the fur had not been } \\
\text { removed. Upon the edge of this dais sat a young } \\
\text { female Waz-don. In one hand she held a thin piece } \\
\text { of metal, apparently of hammered gold, with } \\
\text { serrated edges, and in the other a short, stiff brush. } \\
\text { With these she was occupied in going over her } \\
\text { smooth, glossy coat which bore a remarkable } \\
\text { resemblance to plucked sealskin. Her loin cloth of } \\
\text { yellow and black striped JATO-skin lay on the } \\
\text { couch beside her with the circular breastplates of } \\
\text { beaten gold, revealing the symmetrical lines of her } \\
\text { nude figure in all its beauty and harmony of } \\
\text { contour, for even though the creature was jet black } \\
\text { and entirely covered with hair yet she was }\end{array}$ \\
\hline
\end{tabular}




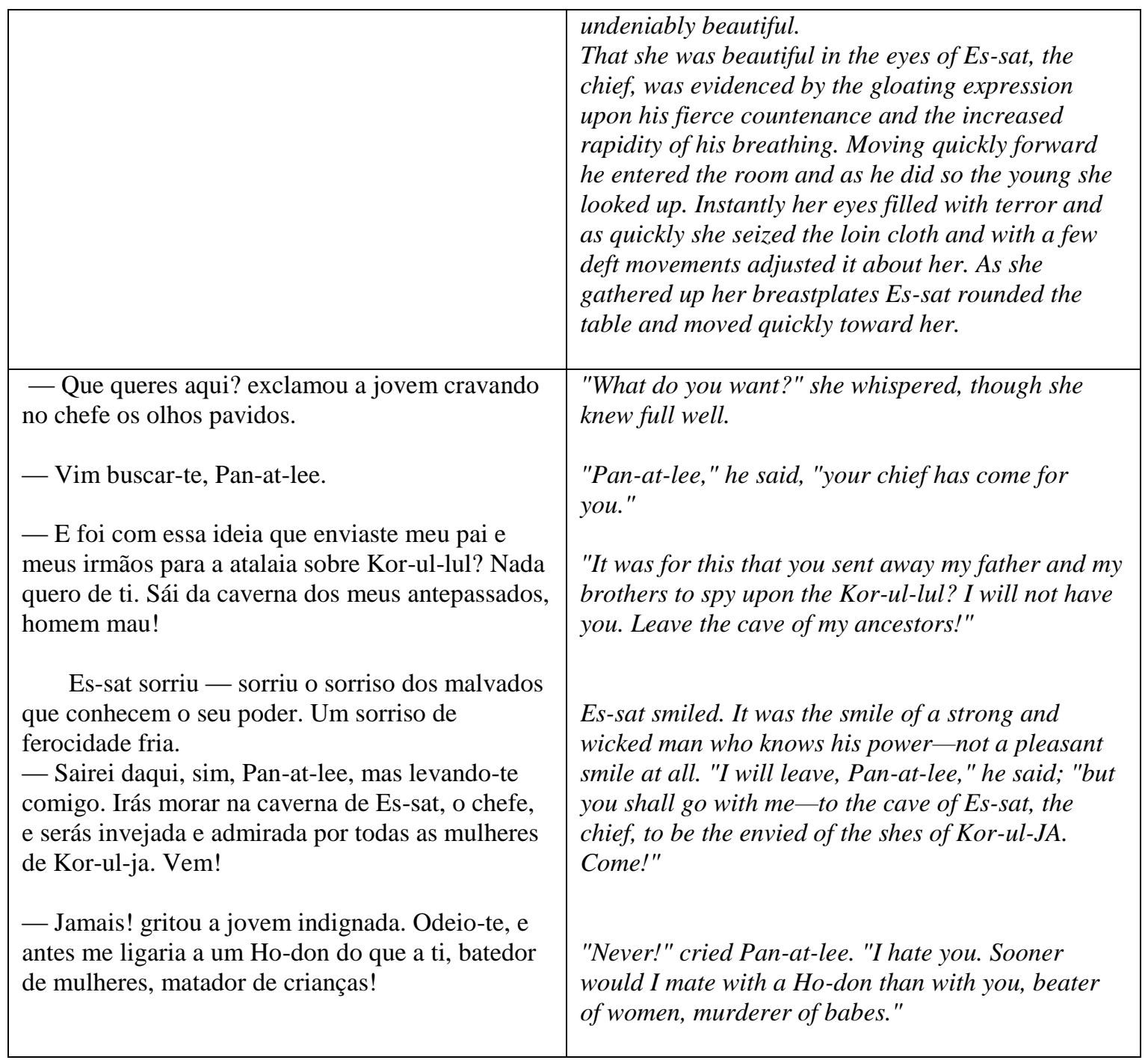

A condensação se mantem ao longo da tradução, porém seguindo estratégias diferentes. Nesta sequência do capítulo 4, algumas falas são suprimidas, ou condensadas no discurso indireto; a informação ora tem a ordem alterada, ora é dispensada:

Tarzan, o terrível

- Seguirei com você em procura de Pan-atlee, disse Tarzan, e Ta-den repetiu a fala.

Mas onde estava Pan-at-lee? Nenhum membro da tribu pôde dar a menor indicação. Ninguém sabia sequer que ela tivesse desaparecido. Tarzan pediu para ver qualquer coisa que lhe pertencesse, roupa, um objeto qualquer de uso.
Tarzan, the terrible

"I," said Tarzan, "will go with Om-at to search
for Pan-at-lee."
"And I," said Ta-den.
It was the first acknowledgment of Om-at's
chieftainship and immediately following it the
tenseness that had prevailed seemed to relax-
the warriors spoke aloud instead of in
whispers, and the women appeared from the
mouths of caves as with the passing of a

"I," said Tarzan, "will go with Om-at to search 
Tinha uma ideia na cabeça. Dois jovens guerreiros chegaram até á abertura ocupada por Om-at e ofereceram- se para tambem acompanha-lo na pesquisa. Era já uma demonstração de que de fato o aceitavam como chefe. A atmosfera tensa que ainda persistia foi-se modificando. A conversação retomou o tom habitual. A tempestade passara. Grupos de mulheres e crianças saiam já de rumo aos campos de cultura.

Om-at conduziu Tarzan para o interior da caverna e mostrou-lhe as coisas de Pan-at-lee. O homem-macaco farejou tudo, qual um cão mestre de caça e disse: Pronto. Podemos partir.

Mas enquanto Om-at meditava, incerto, indeciso de por onde começar a pesquisa, Tarzan, cujo faro se apurara a um grau incrivel e cuja inteligencia tinha as finuras da dos grandes policiais, estudou a situação dos espeques mais proximos da abertura por onde a jovem devia ter escapado e pelo olfato logo apanhou um que ainda conservava o odor vago da fugitiva. E desse primeiro passou ao segundo e depois aos furos sem espeques nos quais Pan-at-lee fora colocando os que levara de reserva. Essa investigação provou que a jovem subira sempre, rumo ao tope da escarpa. sudden storm. In-sad and O-dan had taken the lead and now all seemed glad to follow. Some came to talk with Om-at and to look more closely at Tarzan; others, heads of caves, gathered their hunters and discussed the business of the day. The women and children prepared to descend to the fields with the youths and the old men, whose duty it was to guard them.

"O-dan and In-sad shall go with us," announced Om-at, "we shall not need more. Tarzan, come with me and I shall show you where Pan-at-lee sleeps, though why you should wish to know I cannot guess-she is not there. I have looked for myself."

The two entered the cave where Om-at led the way to the apartment in which Es-sat had surprised Pan-at-lee the previous night.

"All here are hers," said Om-at, "except the war club lying on the floor-that was Essat's."

The ape-man moved silently about the apartment, the quivering of his sensitive nostrils scarcely apparent to his companion who only wondered what good purpose could be served here and chafed at the delay.

"Come!" said the ape-man, presently, and led the way toward the outer recess.

Here their three companions were awaiting them. Tarzan passed to the left side of the niche and examined the pegs that lay within reach. He looked at them but it was not his eyes that were examining them. Keener than his keen eyes was that marvelously trained sense of scent that had first been developed in him during infancy under the tutorage of his foster mother, Kala, the she-ape, and further sharpened in the grim jungles by that master teacher - the instinct of self-preservation.

From the left side of the niche he turned to the right. Om-at was becoming impatient.

"Let us be off," he said. "We must search for Pan-at-lee if we would ever find her." 


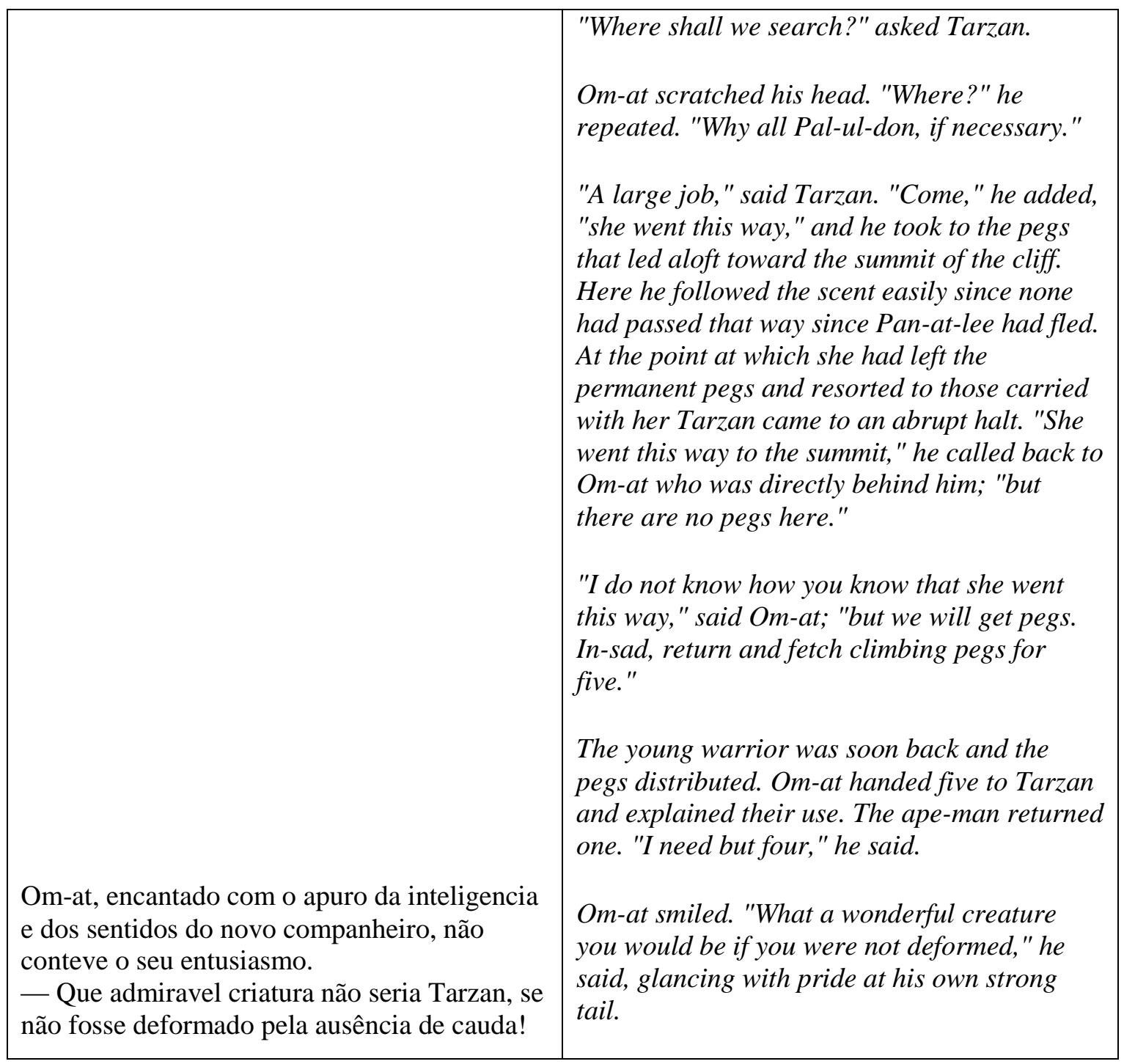

O alinhamento dos textos de partida e de chegada de Tarzan, o terrível foi extremamente dificultado pelo trabalho de Lobato. O mesmo não ocorreu com $O$ tesouro de Tarzan e Tarzan, o rei da jângal, cujos excertos suprimidos são pequenos, possibilitando a comparação parágrafo a parágrafo. Desses dois títulos apenas em $O$ tesouro de Tarzan, tradução de Manuel Bandeira, três parágrafos são totalmente omitidos, contudo, sem prejuízo da narrativa:

Here the ape-man arranged the garments upon his shaggy fellows and himself, until, at a distance, it might have appeared that three white-robed Arabs squatted silently among the branches of the forest (Capítulo 16).

Pausing beside the man, the ape bent over and examined his belongings. Great as was the strength of Chulk there lay in the back of his little brain a something which deterred him from arousing the man to combat - a sense that is inherent in 
all the lower orders, a strange fear of man, that rules even the most powerful of the jungle creatures at times (Capítulo 19).

Shrieking out his terror, the soldier clawed with puny fingers at the shaggy breast in vain endeavor to push away the grinning jaws. The lion lowered his head, the gaping fangs closed with a single sickening crunch upon the fear-distorted face, and turning strode back across the body of the dead horse dragging his limp and bloody burden with him (Capitulo 23).

Se os dois primeiros excertos acima, aparentemente, não apresentam nada "inadequado", o terceiro descreve uma violenta cena do ataque de um leão, que poderia ser considerada inapropriada ao leitor jovem. As omissões de termos, locuções e orações podem ocorrer por diferentes motivos: para atenuar assuntos polêmicos, pela falta de termo correspondente ou por razões estilísticas, resultando em um tipo de manipulação mais ligada às escolhas do tradutor do que aquela imposta pela padronização de tamanho.

Um ponto em comum entre as traduções de Bandeira, Lobato e Rangel é a omissão do "aparato descritivo" é omitido pelos tradutores, talvez por não o considerarem essencial para o entendimento da história, como se pode ver a seguir, em alguns trechos das traduções de Monteiro Lobato, Manuel Bandeira e Godofredo Rangel (doravante identificados por ML, MB e GR).

(1) Era um animal de atitude erecta, firme sobre dois pés e de corpo glabro; tinha os braços musculosos e bem feitos, as mãos com longos dedos e as pernas tambem de boas proporções; já os pés se afastavam do tipo clássico dos pés humanos - os dedos grandes protuberavam em excesso e afastavam-se uns dos outros (ML, p. 7).

It walked erect upon two feet-it walked upon two feet and was hairless except for a black thatch upon its head; its arms were well shaped and muscular; its hands powerful and slender with long tapering fingers and thumbs reaching almost to the first joint of the index fingers. Its legs too were shapely but its feet departed from the standards of all races of men, except possibly a few of the lowest races, in that the great toes protruded at right angles from the foot.

A passagem acima descreve o primeiro encontro de Tarzan com uma criatura cuja evolução está entre o homem e o macaco, por isso o detalhamento das características físicas. A tradução da descrição da criatura é mais concisa. A repetição do jeito de andar, que enfatiza um aspecto humano, é eliminada e a ação é substituída pela postura da criatura. Há, também, simplificação na descrição das mãos e dos pés. Ainda, com a supressão da menção à cabeleira, perde-se a imagem do contraste entre a cabeça com cabelos negros e o corpo desprovido de pelos. A omissão de a few of the 
lowest races (algumas raças inferiores) que aponta o caráter simiesco do humanoide, é curiosamente eliminada, numa época em que a eugenia dava o tom.

Do mesmo capítulo, a bela lua africana é substituída por clareira, atenuando o caráter evocativo que o nome África exerce na imaginação do leitor, que é transportado para um lugar exótico, perigoso e belo, na descrição de Burroughs.

(2) Fazendo breve pausa numa clareira mais abundantemente iluminada, a criatura voltou o rosto numa direção e apurou os ouvidos, como cismada de algo, e nesse momento quem o observasse poderia claramente discernir suas feições (ML, p. 7).

Pausing momentarily in the full light of the gorgeous African moon the creature turned an attentive ear to the rear and then, his head lifted, his features might readily have been discerned in the moonlight.

A vegetação exuberante da selva africana é um dos recursos de grande valor apelativo do qual lança mão o autor, mas que nem sempre é reproduzido na tradução. $O$ quadro é novamente simplificado com a eliminação da grande árvore cujos galhos se debruçavam sobre o riacho.

(3) Haviam caminhado assim mais de milha quando o pitecantropo saltou em terra, numa rechã relvosa que um riacho de aguas limpidas cortava (ML, p. 14).

They had proceeded for a mile or two when Tarzan's companion came to earth upon a grassy slope beneath a great tree whose branches overhung a clear brook.

Abaixo, a luta de Tarzan com o leão, que é minuciosamente descrita no original, ganha uma versão condensada em a "tática de costume". Apesar de se manter a sequência dos movimentos, muitos detalhes são suprimidos. As palavras da língua daquele povo, inventada por Burroughs e que servem para dar "cor local" à narrativa são ignoradas. O resultado é um texto que não remete o leitor nem a uma situação incomum e nem a um lugar diferente de outras narrativas.

(4) Nesse momento Tarzan, rapido como o raio, projetou-se contra o bolide rajado e enlaçou-o pelo pescoço, na sua tática do costume. Homem e fera, engalfinhados, rebolaram sobre o ervaçal sem que os outros, já erguidos, achassem jeito de intervir. Da goela do leão irrompiam urros tremendos de raiva e desespero, e tudo fazia ele para desajolar de si o cingulo vivo que o asfixiava. Subito, um rugido de dor atroou os ares. A lamina de Tarzan se havia cravado em seu coração. (ML, p. $38)$.

Taking advantage of its opportunity the lion rose to throw itself upon $\boldsymbol{O}$-dan and at the same instant Tarzan flung himself upon its back. Strong, white teeth buried themselves in the spotted neck, mighty arms encircled the savage throat and the sinewy legs of the ape-man locked themselves about the gaunt belly. The others, 
powerless to aid, stood breathlessly about as the great lion lunged hither and thither, clawing and biting fearfully and futilely at the savage creature that had fastened itself upon him. Over and over they rolled and now the onlookers saw a brown hand raised above the lion's side - a brown hand grasping a keen blade. They saw it fall and rise and fall again-each time with terrific force and in its wake they saw a crimson stream trickling down JA's gorgeous coat.

$\mathrm{Na}$ história à qual pertencem estes fragmentos, os antagonistas de Tarzan são criaturas com físico entre o macaco e o homem e o fato de Tarzan não possuir rabo é importante, pois sendo diferente o herói vai ludibriar os inimigos fazendo-se passar por filho da divindade local. Contudo, o tradutor parece não achar necessário que isso seja enfatizado, uma vez que a informação já havia sido dada anteriormente.

(5) Realmente, murmurou O-lo-a. Sua figura é impressionante de beleza e força. Não só pelas peculiaridades das maos e dos pés, mas no ar, parece-me uma criatura diferente de todas as mais (ML, p. 110).

"He was indeed a wonderful man to look upon," mused O-lo-a, "and he was not as are other men, not alone in the conformation of his hands and feet or the fact that he was tailless, but there was that about him which made him seem different in ways more important than these."

Nos excertos de outro livro a seguir, o tradutor, ao eliminar elementos imprime mais objetividade e agilidade ao trecho, mas perde um sentido implícito. A simplificação na tradução diminui a expectativa de que, no decorrer da narrativa, o temor do belga, que lhe calou fundo na alma, com relação a Tarzan, iniciado neste evento inicial, crescerá.

(6) Datava dessa ocorrencia o grande medo do belga ao seu brutal companheiro (MB, p. 54).

From that occurrence dated the beginning of a great fear in the breast of the Belgian for his savage companion.

Na ocorrência abaixo, a omissão de hideous little men não prejudica a imagem dos sacerdotes na mente do leitor, pois eles foram descritos anteriormente como "horrendos sacerdotezinhos" (p. 79) e "grotescos homúnculos da sua tribo" (p. 79), todavia, a supressão do fato de eles estarem armados à espera de Tarzan enfraquece o clima de hostilidade.

(7) La e os sacerdotes reuniram-se em silencio, á espera que regressasse o cabeludo antropoide (MB, p. 81).

La and the priests gathered silently together, the hideous little men fingering their knives and bludgeons, and awaited the return of the shaggy anthropoid. 
Tarzan, retratado em sua persona selvagem, frequentemente se porta de maneira simiesca, mas muitos adjetivos que Burroughs utiliza para assim caracterizar o herói são ignorados na tradução. Por causa da sua vida ao ar livre e por andar seminu os adjetivos strong e brown se impõem como termos expressivos para a caracterização da personagem e poderiam ser facilmente traduzidos. Já a imagem transmitida por reached out, cuja ideia é acentuada pelo advérbio que designa a maneira exata da posição, obrigaria o tradutor a fazer acréscimos, glosas, para descrever a posição da perna.

(8) Viram eles então a figura gigantesca do homem-macaco estendida num galho baixo. Mesmo adormecido, segurava com uma das mãos o tronco de uma ramada, e tinha uma perna passada sobre a outra. (MB, p. 82).

There they saw the giant form of the ape-man stretched along a low bough and even in sleep one hand grasped a stout limb and one strong, brown leg reached out and overlapped another.

Também nestas duas passagens, são omitidos elementos que descrevem Tarzan. No primeiro trecho (9) as suas qualidades de mighty fighter, mighty hunter (poderoso combatente, poderoso caçador), tem a força expressiva explorada pela repetição; no segundo (10), o adjetivo bronzed (bronzeado) não só descreve a cor da pele do herói, mas também tem valor evocativo lembrando de sua vida ao ar livre andando quase nu pela selva, o que o difere de outros lordes ingleses.

(9) - Parem! - ordenou elle, erguendo a mão aberta para chamar a attenção. - Eu sou Tarzan dos Macacos, poderoso combatente. Há muito pertencia á tribu de $\operatorname{Kerchak}$ (GR, p. 30).

"Stop!" he commanded raising his opened palm to attract attention. "I am Tarzan of the Apes, mighty hunter, mighty fighter; long did I range with the tribe of Kerchak.

(10) Conservou-se de pé, a observar o gigante dirigir-se para o lado do gorilla (GR, p. 40).

He just stood and watched the bronzed giant turn to the gorilla.

Novamente estes dois trechos evidenciam a condição selvagem de Tarzan e sua luta com as feras. A maneira de Tarzan se locomover na selva é eliminada no primeiro (11) e no segundo (12), a detalhada morte do leão. Nas duas passagens, observa-se uma característica da língua inglesa, que é o grande número de verbos muito específicos para descrever cenas estáticas ou de movimento. A transposição para o português acarreta acréscimos e/ou perda de material semântico. No caso, o tradutor opta pela omissão. 
(11) - Deus do céu! Gritou. - Pode estar sim, e os leões estão atacando! Os leões penetraram no acampamento - conheço pelo rincho dos cavalos. Estás ouvindo? O grito de um homem nas vascas da morte! Espera-me aqui até que eu volte. Preciso primeiro socorre-los! (MB, p. 191).

"God!" he cried, "she might be, and the lions are attacking them - they are in the camp. I can tell from the screams of the horses - and there! that was the cry of a man in his death agonies. Stay here man - I will come back for you. I must go first to them", and swinging into a tree the lithe figure swung rapidly off into the night with the speed and silence of a disembodied spirit.

(12) Viu a fera enfraquecer-se com a perda de sangue. Viu o deus ou o demonio da mata erguer-se de cima do inimigo vencido, e pondo um pé sobre a carcaça ainda palpitante, levantar a face para a lua e soltar um grito horroroso que gelou o sangue nas veias do feiticeiro (MB, p. 22).

He saw the lion weaken from loss of blood. He saw the mighty limbs tremble and stagger and at last he saw the beast sink down to rise no more. He saw the forest god or demon rise from the vanquished foe, and placing a foot upon the still quivering carcass, raise his face to the moon and bay out a hideous cry that froze the ebbing blood in the veins of the witch-doctor.

Muitas são as feras descritas nessa história. A passagem a seguir narra o ataque de um rinoceronte contra Tarzan.

(13) Senão quando o homem-macaco sentiu que qualquer coisa se aproximava atrás dele, e voltando-se rapido, deu com Buto, o rinoceronte, carregando furiosamente e já tão perto que toda salvação parecia impossível (MB, p. 76).

[...] and then he turned to see Buto, the rhinoceros, his little pig eyes blazing, charging madly toward him and already so close that escape seemed impossible.

A locução adjetiva his little pig eyes blazing é ignorada na tradução, pois a expressão "olhinhos de porco" poderia estar em desacordo com a ideia de ferocidade, apesar de o rinoceronte ter mesmo olhos pequenos. Contudo, essa hipótese é anulada pelo trecho da cena de um elefante enraivecido em que o tradutor acrescenta o diminutivo:

(14) Vendo que não conseguiria derrubar a arvore, Tantor ficou ainda mais enraivecido. Olhou para os dois empoleirados no alto, e os seus olhinhos raiados de vermelho fuzilaram de odio (MB, p. 91).

Finding that the tree would not fall to his pushing, Tantor was but enraged the more. He looked up at the two perched high above him, his red-rimmed eyes blazing with insane hatred.

O sufixo do diminutivo acrescentado a uma palavra sem valor emotivo, no caso "olhos", pode ter um valor tanto apreciativo como depreciativo, exprimindo por um lado ternura ou delicadeza e por outro, ironia e desdém. Uma escolha mais neutra seria 
"pequenos olhos", pois remeteria preferencialmente às dimensões. Interessante notar que outro tradutor também usa o diminutivo quando no original o substantivo olhos é qualificado pelo adjetivo "fraco", insinuando que o animal não enxerga bem.

(15) Não concluirá ainda Tarzan o exame do recinto e já o grifo se aproximou numa galopada louca, aos urros. Entreparou na entrada, circunvagando os olhinhos apertados em procura da presa que lhe fugira (ML. p118).

There was no staff with which to enforce the authority of his voice, but yet he made his stand for there seemed naught else to do. Just beyond the entrance to the corridor the GRYF paused, turning its weak eyes in all directions as though searching for its prey.

De acordo com a tabela comparativa do número de palavras entre original e tradução, no início desta seção, o tradutor que menos interfere no texto, nesse sentido, é Godofredo Rangel, em Tarzan, o rei da jângal. Como nas outras traduções, a supressão também se verifica nas descrições de cenas, sempre mais detalhadas no original inglês. Muitas omissões não prejudicam o entendimento do texto e muitas vezes o tornam mais fluente e objetivo, prendendo a atenção do leitor com mais facilidade; entretanto, fazem com que o texto em português se distancie do estilo descritivo do autor do original.

(16) Desde pouco depois do escurecer até quasi o despontar do dia, reinou um perfeito pandemonio de uivos, roncos, bufos, grunhidos e ladridos bem de baixo de sua arvore, como se todas as féras das mattas houvessem emprazado reunir-se alli (GR, p.56).

From shortly after dark until nearly dawn a perfect bedlam of howls and growls and coughs and grunts and barks arose from directly beneath him as there had been held a convention of all the horrid beasts of the jungle at the foot of the tree that seemed at best an extremely insecure sanctuary.

(17) Atravessada naquelle taboleiro penhascoso havia uma solida muralha de pedra, flanqueada de grandes torres redondas com altas e estreitas torres setteiras. Via-se no meio da muralha uma lata porta elevadiça, alem da qual Blake divisou dois negros a montar guarda. Os trajos destes eram exactamente iguaes aos dos seus captores, mas achavam-se armados de alabardas cujas hastes descansavam no chão (GR, p. 70).

Across the shelf stood a solid wall of masonry flanked at either side by great, round towers pierced by long, narrow embrasures. In the center of the wall was a lofty gateway which was closed by a massive and handsomely wrought portcullis behind which Blake saw two Negroes standing guard. They were clothed precisely as his captors, but held great battle-axes, the butts of which rested upon the ground.

(18) Um unico e medonho grito quasi humano sahiu da garganta de Bolgani, assim teve acordo de sua má sorte; e barafustou, a tentar inutilmente libertar-se daquelles convolvulos de rijo aço vivo, que o iriam esmagar, esmagar até sua tremenda 
pressão esphacelar-lhe os ossos, até que todo elle se transfizesse em uma pasta, que desappareceria entre as mandibulas escancelladas da serpente (GR, p. 34).

A single hideous, almost human scream burst from the lips of Bolgani with the first realization of the disaster that had befallen him, and then he was on the ground tearing futilely at the steadily tightening bands of living steel that would crush the life from him, crush until his bones gave to the tremendous pressure, until only broken pulp remained within a sausage like thing that would slip between the distended jaws of the serpent.

Muitas vezes redundâncias, hipérboles e informações adicionais são ignoradas pelos tradutores, como se pode observar nestes trechos selecionados nos três livros. Nos próximos excertos a eliminação de termos mais uma vez simplifica a leitura. $\mathrm{O}$ trecho a seguir (19) é parte de um diálogo no qual Tarzan interpela a sacerdotisa La. No contexto está clara a intenção por parte do herói de esclarecer tudo, o o tradutor não vê necessidade de explicitá-la:

(19) - Então por que motivo desejavas mata-lo? (MB, p. 48)

"Then why should you have wished to kill him?" Tarzan was determined to get to the bottom of the thing.

Novamente a omissão influencia na caracterização da personagem que tem poderes humanos e animais e que Burroughs faz questão de enfatizar sempre:

(20) O clarão da lua insinuava-se pela galhaça, e o animal tinha o cuidado de evitar as claras manchas denunciadoras e embora se movesse num espesso intrincado de vegetais e tranqueira de arvores mortas, sabia agir de modo a não provocar o menor rumor (ML, p. 7).

The jungle moon dappled an occasional clearing which the great cat was always careful to avoid. Though he moved through thick verdure across a carpet of innumerable twigs, broken branches, and leaves, his passing gave forth no sound that might have been apprehended by dull human ears.

O fato de Tarzan ter sido criado na selva obriga-o a um treinamento de sobrevivência no qual se inclui aprender a matar. O texto em inglês faz menção a essa primeira experiência de Tarzan atenuando o aspecto criminoso do ato, mas que não é insinuado na tradução (21).

(21) Achou-o afinal - a pesada lança de guerra em anos passados consistia ponto tão essencial da sua vida cotidiana, quasi da sua mesma existencia, tão inseparavelmente ligada estivera a todos os seus atos desde o dia remoto em que arrancara a primeira lança do corpo trespassado de um negro sua vítima (MB, p. 43). 
At last he found it - the heavy war spear that in past years had formed so important a feature of his daily life, almost of his very existence, so inseparably had it been connected with his every action since the long-gone day that he had wrested his first spear from the body of a black victim of his savage training.

\subsubsection{A ambientação}

A representação do continente africano na mente do leitor do início do século 20 era bem diferente da dos dias de hoje. Enquanto hoje em dia, a mídia revela quase em tempo real a dura realidade africana de corrupção, epidemias, fome e êxodo, a África de Burroughs é exótica e misteriosa, idealizada como nas literaturas coloniais de Rudyard Kipling e Joseph Conrad. Entretanto, mesmo entre as histórias de Tarzan e esses relatos são poucas as conincidências, pois nos textos de Burroughs a África é habitada por uma fauna fantástica de espécies ignoradas pela zoologia, onde os símios apresentam sentimentos humanos e os animais dialogam com Tarzan em uma linguagem própria.

\subsection{2. a) A selva africana}

Todas as histórias de Tarzan tem a África como pano de fundo, mas os deslocamentos constantes do herói levam o leitor a cenários ainda mais fantasiosos como as ruinas de Atlântida, em $O$ tesouro de Tarzan, a cidade de um povo ancestral que habita um vale que por suas características remete à pré-história, em Tarzan, $o$ terrível e uma cidade medieval fortificada dos cruzados em pleno coração da África subsaariana, em Tarzan, o rei da jângal. Esses espaços criam campos semânticos específicos, que resultam em diferentes soluções, conforme o tradutor. Primeiramente, será enfocada somente a ambientação na floresta por ser um elemento comum às três histórias.

Nesse espaço mítico, jungle é palavra-chave, aparecendo 296 vezes contra 106 do seu sinônimo forest, em um total de 402 ocorrências nos três livros analisados. Nas traduções, esse vocábulo ocorre, no total, quase a metade das vezes. Uma das razões seria a omissão de passagens descritivas, comentada anteriormente. Em português, "jângal", termo dicionarizado ${ }^{150}$ na época das traduções, vem do hindi jangaal, todavia

${ }^{150}$ Caldas Aulete de 1925: jângal, s. m. (Índia Port.) matagal, floresta densa. 
os tradutores preferem os quase sinônimos, expandindo o léxico conforme se verifica no quadro abaixo:

\begin{tabular}{|l|c|r|r|c|}
\hline & MB & ML & GR & Total \\
\hline floresta & 39 & 30 & 37 & 106 \\
\hline mata & 43 & 6 & 0 & 49 \\
\hline selva & 1 & 5 & 35 & 41 \\
\hline jângal & 0 & 12 & 1 & 13 \\
\hline juncal & 1 & 0 & 0 & 1 \\
\hline Total & 84 & 53 & 73 & 210 \\
\hline
\end{tabular}

Tabela 7: Termos em português para jungle

Os aspectos expressivos das palavras "floresta", "mata" e "selva", mesmo apresentando o mesmo valor referencial, estão ligados a diferentes representações mentais segundo as referências locais do leitor. "Selva africana" é uma colocação corrente e evoca um lugar diferente da floresta amazônica, da zona da mata, ou da mata atlântica. Todavia, Bandeira dá preferência a "mata", Lobato, a "floresta", e Rangel adota tanto "floresta" quanto "selva". Vale observar que a única vez que Rangel utiliza "jângal" é no título, não mantendo o termo no corpo do texto, substituindo aquela expressão por "Senhor das Florestas". Pode-se especular que o título tenha sido de escolha do editor:

(1a) Tantor sentia-se immerso em grande somnolencia, emquanto Tarzan, o Senhor das Florestas, cochilava nas costas do seu possante amigo (GR. p. 8).

But there were no other eyes to see and Tantor drowsed in the heat of midday and Tarzan, Lord of the Jungle, dozed upon the back of his mighty friend.

(2a) "Esperem até que volte Tarzan, o Senhor das Florestas!" (GR. p.11).

"Wait," they have said," until Tarzan, Lord of the Jungle, returns".

(3a) - Eu sou Tarzan, o Senhor das Florestas - respondeu o homem-macaco. A palavra de Tarzan é a lei nas selvas (GR. p. 38).

"I am Tarzan, Lord of the Jungle," replied the ape-man. "The word of Tarzan is law in the jungle".

(4a) - Eu sou Tarzan dos Macacos, o Senhor das Florestas (GR. p. 49).

"I am Tarzan of the Apes," he said, "Lord of the Jungle". 
A alcunha não é mencionada nenhuma vez em Tarzan and the jewels of Opar e uma em Tarzan, the terrible, mas não foi traduzida porque consta de um trecho omitido:

(5a) A principio sua ideia fora verificar se podia por algum tempo dominar o seu perseguidor até o momento em que pudesse fugir. Depois de montado, entretanto, experimentou a tentação de refazer os dias da meninice, em que pela primeira vez se viu sobre o dorso de Tantor, o elefante. Já que dominara o grifo, iria tirar disso o melhor partido (ML, p. 67).

But once seated upon the back of his titanic mount the ape-man experienced the sensation of a new thrill that recalled to him the day in his boyhood that he had first clambered to the broad head of Tantor, the elephant, and this, together with the sense of mastery that was always meat and drink to the lord of the jungle, decided him to put his newly acquired power to some utilitarian purpose.

Nesses romances, o cenário hostil, cheio de mistérios e perigos, pode exercer forte influência no europeu que ali vive. Em $O$ tesouro de Tarzan, essa referência aparece logo no primeiro capítulo quando o belga Werper se revolta contra o seu capitão. A tradução de Bandeira de jungle madness para "loucura da mata" enfraquece o seu valor evocativo:

(6a) O capitão, com uma expressão de surpresa nos olhos, voltou-se para o seu subalterno. Já vira antes muitos homens com a loucura da mata impressa na fisionomia - a loucura causada pela solidão, pelas cismas sem fim, e talvez por um acesso de febre (MB, p. 6).

The captain, an expression of surprise upon his features, turned toward his junior. He had seen men before with the jungle madness upon them - the madness of solitude and unrestrained brooding, and perhaps a touch of fever.

Outra observação a respeito das traduções da palavra de jungle é o uso de "juncal". Talvez o tradutor tenha optado por esse termo porque na passagem reedy é relativo a reed, gramínea delgada e flexível que nasce em terreno alagado. Na ausência de uma palavra correspondente em português, Bandeira funde determinante e determinado em um só vocábulo:

(7a) A umas cem jardas de distancia havia uma grande arvore isolada na ourela do juncal (MB, p. 71).

A hundred yards from where he stood grew a large tree, alone upon the edge of the reedy jungle.

Nesse ambiente tudo é selvagem - o lugar, as feras, as pessoas, os sentimentos, as atitudes - e muitos são os adjetivos que os qualificam. Pertencentes ao mesmo campo semântico de jungle foram localizados os seguintes nos textos fontes: 


\begin{tabular}{|l|c|c|c|c|}
\hline & The jewels of Opar & The terrible & Lord of the jungle & Total \\
\hline savage & 69 & 56 & 19 & 144 \\
\hline wild & 22 & 26 & 44 & 92 \\
\hline cruel & 15 & 19 & 3 & 37 \\
\hline fierce & 10 & 15 & 5 & 30 \\
\hline ruthless & 1 & 6 & 3 & 10 \\
\hline brutal & 4 & 0 & 1 & 5 \\
\hline Total & 121 & 122 & 75 & 318 \\
\hline
\end{tabular}

Tabela 8: Adjetivos do campo semântico de jungle

Novamente há um número maior de ocorrências dos adjetivos em inglês (218) do que em português (128), mas deve-se considerar que os textos fontes foram reduzidos com a exclusão de muitos trechos. Para os adjetivos em inglês acima elencados, os tradutores utilizam os seguintes adjetivos em português:

\begin{tabular}{|l|c|c|c|c|}
\hline & MB & ML & GR & Total \\
\hline selvagem & 40 & 1 & 16 & 57 \\
\hline feroz & 11 & 14 & 8 & 33 \\
\hline cruel & 6 & 11 & 10 & 27 \\
\hline brutal & 4 & 3 & 2 & 9 \\
\hline atroz & 0 & 2 & 0 & 2 \\
\hline Total & 61 & 31 & 36 & 128 \\
\hline
\end{tabular}

Tabela 9: Adjetivos em português do campo semântico de selva

Interessante notar a grande discrepância no uso de "selvagem" entre os tradutores. Pela definição do dicionário Houaiss, "selvagem" define-se como o que é "próprio das selvas" ou "que se manifesta numa natureza não civilizada", o sentido pode ser tanto literal quanto figurado. Os adjetivos em português não obedecem a um padrão de correspondência com aqueles em inglês e se apresentam de maneira intercambiável, mesmo levando em conta que não existe sinonímia perfeita. De maneira geral, cruel, ruthless fierce, brutal são traduzidas pelos seus correspondentes mais frequentes "cruel", "feroz" e "brutal". A tradução de savage por "selvagem" é a mais frequente em duas narrativas, como ilustram os cinco exemplos abaixo:

(8a) Werper conseguira sentar-se. Ele, tambem, via as cataduras selvagens dos antropoides e não sabia se devia respirar aliviado ou tremer de pavor (MB, p. 188). 
Werper had managed to sit up. He, too, saw the savage faces of the approaching anthropoids and scarcely knew whether to be relieved or terror-stricken.

(9a) Os uivos e bufidos dos enormes felinos misturavam-se á miríade de ruidos dos habitantes menores da floresta para espertar a chama selvagem no peito do selvagem lord inglês (MB, p. 16).

The moans and the coughing of the big cats mingled with the myriad noises of the lesser denizens of the jungle to fan the savage flame in the breast of this savage English lord.

(10a) Um gigante na estatura, guerreiro selvagem e intrépido, o enorme negro possuia tambem alma e bom senso na proporção da sua corpulência e da sua fereza (MB, p. 36).

A giant in stature, a savage, fearless warrior, the huge black possessed also soul and judgment in proportion to his bulk and his ferocity.

(11a) Toyat procurava excitar-se para attingir o auge da furia, e cobrar então coragem para atacar o Tarmangani, e com esse procedimento buscava tambem espertar o selvagem espirito combativo de seus companheiros (GR, p. 28).

Toyat was working himself to a pitch of rage that would nerve him to attack the Tarmangani, and by these maneuvers he hoped also to arouse the savage fighting spirit of his fellows.

(12a) Kerchak personificava a ferocidade e a autoridade selvagem e, mesmo ao lembral-o agora, sentia uma impressão de temor respeitoso. E parecia-lhe quasi incrivel que elle, Tarzan, tivesse subjugado e matado aquelle rei gigantesco. (GR, p.30).

Kerchak had been the personification of savage ferocity and authority, and even today he recalled him with almost a sensation of awe. That he had overthrown and slain this gigantic ruler still seemed to Tarzan almost incredible.

(13a) Um trovão ribombou longe, no firmamento que se escurecia e os dois entes da selva olharam para cima, para os amplos dominios das forças da Natureza, mais selvagens e destruidoras que as suas próprias (GR, p. 49).

From the darkening sky distant thunder boomed and the two beasts looked upward toward the broad field of Nature's powers, more savage and destructive than their own.

$\mathrm{Na}$ terceira narrativa, a tradução de Lobato, apesar de o texto fonte apresentar cinquenta e seis vezes savage, o tradutor só opta uma vez por "selvagem":

(14a) Os alemães estavam realmente enfuriados com o semi-selvagem companheiro daquela criatura, que vinha agindo como o demonio da astúcia na perseguição desenvolvida contra eles (ML, p. 137).

Bitter indeed were the Germans against that half-savage mate of hers who had cunningly annoyed and harassed them with a fiendishness of persistence and ingenuity that had resulted in a noticeable loss in morale in the sector he had chosen for his operations. 
Em outra passagem, prefere usar uma variação do termo:

(15a) Puseram-se em marcha pela meia encosta da montanha escarpada, ora ameaçados pelos seus selváticos habitantes, ora vislumbrando, dentro das sombras da noite, estranhas formas de monstros desconhecidos (ML p. 18).

For several days their way led through the foothills parallel to the lofty range towering above. Often were they menaced by the savage denizens of this remote fastness, and occasionally Tarzan glimpsed weird forms of gigantic proportions amidst the shadows of the nights.

Pelo cotejo do original e tradução e, também, pela comparação do total de adjetivos desse campo semântico no texto traduzido por Lobato, verificou-se que, na maioria das vezes ele omite o adjetivo savage, não só devido ao método de condensação global da obra, como também em favor de uma simplificação da narrativa, como ilustram os cinco exemplos abaixo:

(16a) Um golpe de pata de Numa apanhou-o de flanco, ferindo fundo, mas a lamina já se cravara e se recravava de novo no dorso da fera, fulminantemente (ML, p. 11).

A raking talon caught Tarzan on the side, inflicting a long, deep wound and then the ape-man was on Numa's back and the blade was sinking again and again into the savage side.

(17a) Pan-at-lee encaminhou-se para a sua aldeia (ML, p. 64).

She moved therefore through her savage land.

(18a) O recem-vindo apontou para o remanescente da carcassa de Bara, a corça, e tocou com o dedo o estomago e a boca, sinal evidente de vontade de comer, e com outro gesto por igual compreensivel Tarzan o convidou a compartilhar da pitança (ML, p. 13).

With a wave of his hand Tarzan invited his guest to partake of the remains of his savage repast, and the other, leaping nimbly as a little monkey to the lower branches of the tree, made his way quickly to the flesh, assisted always by his long, strong sinuous tail.

(19a) - Blasfemo! Conspurcador do templo! gritaram uns, ao passo que outros, ainda crentes de que ele fosse na realidade o filho de deus, esclamavam com reverencia: Dor-ul-Otho! (ML, p. 134).

"Blasphemer!" "Defiler of the temple!" burst hoarsely from savage throats, and mingling with these were a few who cried, "Dor-ul-Otho!"

Os termos wild, como savage, também tem sentido figurado e literal, significando tanto próprio da selva, não domesticado - wild -, como ter um sentido de 
crueldade, ambas acepções correspondendo a "selvagem", na maioria das traduções, como por exemplo em (20a).

(20a) - Ou algum selvagem da floresta - suggeriu outro. - Em que parte do corpo a bala acertou, Fahd? (GR, p. 10)

"Or some wild man of the forest," suggested another. "Where did thy bullet strike him, Fahd?"

Contudo, em algumas ocasiões o tradutor busca outro equivalente, provocando outro efeito. No texto fonte Tarzan é descrito como savage por ser um filho da selva, um herói de valores nobres. Trata-se de referência a um estilo de vida e não ao caráter, mas a tradução dá ênfase à visão que o belga tem de Tarzan, ou seja, um bárbaro.

(21a) Datava dessa ocorrencia o grande medo do belga ao seu brutal companheiro (p. 54).

From that occurrence dated the beginning of a great fear in the breast of the Belgian for his savage companion.

No trecho a seguir, onde savage aparece duas vezes, nota-se uma estratégia diferente do tradutor, não somente para evitar a repetição. Para solucionar a questão de raider que não tem um correspondente em português, o tradutor necessita parafrasear o termo. Para o leitor que não tem acesso ao original, a passagem faz todo o sentido, porém, o sentido dado pelo tradutor difere do texto fonte, com os companheiros criminosos que em português viram "diabólicos". Diferença de sentido observa-se, também, na tradução do substantivo abandon, que é um falso amigo e refere-se a um sentimento de entregar-se completamente, sem restrições, diferente da expressão "de corpo e alma" que exprime dedicação.

(22a) Durante meses o renegado belga acompanhou as entradas selvagens daqueles homens. Batalhava de corpo e alma, com dura crueldade, igual em tudo á dos seus diabolicos companheiros (MB, p. 9).

For months the renegade Belgian rode with the savage raider. He fought with a savage abandon, and a vicious cruelty fully equal to that of his fellow desperadoes.

$\mathrm{Na}$ passagem a seguir, o texto fonte ressalta a selvageria dos bandidos de maneira hiperbólica com a repetição de sentido por dois adjetivos sinônimos. Essa característica é amenizada no texto alvo, pois "sinistro" tem o sentido de alguém a quem se deve temer, malfazejo, mas não especifica as características dos bandidos: 
(23a) Os sinistros bandidos haveriam de pôr em postas o cristão que se atrevera a derramar o sangue do chefe (MB, p. 164).

The fierce and brutal raiders would tear to pieces a Christian who had dared spill the blood of their leader.

Ao longo do texto traduzido por Rangel, observam-se outras escolhas para tradução de savage, que não "selvagem", sendo ele o que mais se aproxima em número de correspondências.

Abaixo, o tradutor opta pelo sentido que savage ${ }^{151}$ adquire ao qualificar um lugar que é precismante, inóspito, não cultivado:

(24a) - Ateja, a quem eu amo, ficará em perigo nesta região inhospita emquanto Fahd estiver junto a ella (GR, p. 90).

"Ateja, whom I love, remains here in the savage country in constant danger so long as Fahd be near her [...]".

A seguir, também, toda a tradução da passagem se aproxima em sentido do texto fonte.

(25a) Golpe após golpe continuou, como presa de uma loucura feroz, a cravar a lamina na carne macia de sua victima. Stimbol sentiu sangue quente esguichar-lhe na mão e no pulso (GR, p. 129).

Again and again with savage maniacal force and speed the knife was plunged into the soft flesh. Stimbol felt the warm blood spurt out upon his hand and wrist.

Ainda com relação ao espaço selvagem, três hiperônimos são os mais frequentes para designar a fauna da selva:

\begin{tabular}{|l|c|c|c|c|}
\hline & The jewels of Opar & The terrible & Lord of the jungle & Total \\
\hline beast & 73 & 100 & 47 & 220 \\
\hline animal & 19 & 13 & 8 & 40 \\
\hline carnivore & 12 & 3 & 5 & 20 \\
\hline Total & 104 & 116 & 60 & 280 \\
\hline
\end{tabular}

Tabela 10: Termos nos textos fonte para o campo semântico da fauna

Vocábulo beast é bastante utilizado por Burroughs, pois, naturalmente, todas as histórias transcorrem na selva. Segundo o $O E D$, a primeira acepção de beast é de um grande animal quadrúpede e feroz. Por extensão, o termo pode ser aplicado ao ser humano com características brutais. Uma vez que não há em português um correspondente tão próximo para beast quanto para animal e carnivore, as traduções, com maior frequência, variam entre "fera" e "animal":

${ }^{151} O E D$ : (of a place): wild-looking, and inhospitable; uncultivated. 


\begin{tabular}{|l|c|c|c|c|}
\hline & MB & ML & GR & Total \\
\hline fera & 46 & 38 & 3 & 87 \\
\hline animal & 30 & 14 & 43 & 87 \\
\hline bicho & 18 & 1 & 1 & 20 \\
\hline carnívoro & 18 & 3 & 1 & 22 \\
\hline Total & 112 & 56 & 48 & 216 \\
\hline
\end{tabular}

Tabela 10: Termos nos textos alvo para o campo semântico da fauna

Analisando os números, se por um lado, é de se esperar que o texto de Lobato apresente menor número de vocábulos referentes à fauna devido ao processo de condensação a que foi submetido, por outro, surpreende o aumento deles no texto de Bandeira, que amplia o léxico com o termo "bicho". Enquanto "fera" remete somente ao que é bravio, indômito, selvagem (como beast), "bicho" é um termo mais neutro, que pode evocar tanto selvageria quanto domesticação. Além disso, esse vocábulo ao designar tanto mamíferos quanto insetos, tem seu sentido ampliado em muitas expressões brasileiras tanto literais - bicho de estimação, bicho de pé, jogo do bicho quanto idiomáticas - bicho bom, virou o bicho - formando um repertório na mente do leitro brasileiro que entendo amenizado o aspecto de ferocidade.

Além dos subtítulos dos capítulos 11 e 19, em $O$ tesouro de Tarzan, já comentados, o termo "bicho" é muito adotado por Bandeira na tradução de beast:

(26a) Que Tarzan fôra outrora, em verdade, um bicho bravo da floresta era coisa que Werper desconhecia, e assim não poderia adivinhar que o homem revertera ao estado em que passara a infancia e a primeira mocidade (MB, p. 54).

That Tarzan had once been, in truth, a savage, jungle beast, Werper had not known, and so, of course, he could not guess that the man had reverted to the state in which his childhood and young manhood had been spent.

(27a) Mas Tarzan dos Macacos, na distancia de algumas jardas, podia competir em velocidade até com estes animais, de sorte que mal iniciado o galope, a femea sentiu-se montada por um bicho selvagem. Voltou-se tentando morder e escoucear o inimigo (MB, p. 73).

But Tarzan of the Apes, for a distance of a few yards, could equal the speed of even these, and the first stride of the mare found her overhauled, with a savage beast at her shoulder.

(28a) Os nossos orgãos olfativos estão praticamente atrofiados $\mathrm{cm}$ comparação com o desenvolvimento do mesmo sentido entre os bichos da mata (MB, p. 98). 
We cannot smell at all, our olfactory organs are practically atrophied, by comparison with the development of the sense among the beasts of the wild.

(29a) Atrás de Tarzan vinham os grandes macacos, espantados mas obedientes, ao comando do Tarmangani. Perceberam os arabes que não teriam tempo de cavalgar os animais e disparar antes de serem alcançados pelos bichos e pelo homem (MB, p. 112).

Behind Tarzan came the great apes, wondering, but obedient to his summons. The Arabs saw that they would not have time to mount and make their escape before the beasts and the man were upon them.

Novamente Bandeira opta por "bichos da mata", abaixo, porém a passagem no texto fonte refere-se à floresta selvagem, que inclui não só os animais, mas também homens inimigos e forças da natureza:

(30a) Os seus musculos ansiavam por exercitar-se contra os bichos da mata na batalha pela existencia que fôra durante os primeiros vinte anos de sua vida o seu unico privilegio de nascença (MB, p. 16).

His muscles yearned to pit themselves against the savage jungle in the battle for existence that had been his sole birthright for the first twenty years of his life.

Este trecho é parte do relato do encontro de Tarzan com um gorila macho alfa, consequentemente feroz, atributos implícitos no vocábulo inglês bull que não são transmitidos na tradução.

(31a) Tarzan parecia inclinado a prosseguir na disputa. Acercou-se do bicho truculentamente, estufando o peito e rosnando (MB, p. 51).

Tarzan seemed inclined to pursue the argument. He swaggered truculently, stuck out his chest, roared and advanced closer to the bull.

Ainda com relação a esse vocábulo, há uma coincidência entre a escolha de Bandeira e Rangel para dois termos genéricos marcados pela informalidade, folk e fellow:

(32a) Tarzan acompanhava de palanque aquela batalha real com o mais vivo interesse, pois os bichos mais inteligentes da mata interessam-se muito por tais encontros (MB, p. 77).

From the safety of his perch Tarzan watched the royal battle with the keenest interest, for the more intelligent of the jungle folk are interested in such encounters.

(33a) - Fique de um lado, moço, para eu liquidar esse gorilla — disse Stimbol. - Depois do péga com a serpente, duvido de que goste de que esse bicho pule em você (GR, p. 37). 
"Stand to one side, young fellow," said Stimbol, "while I finish that gorilla. After the experience you just had with the snake, I doubt if you want that fellow to jump you, too".

O termo "bicho" não é da preferência de Lobato para traduzir beast e ele opta por ele somente uma vez. A questão no caso está nos adjetivos que não correspondem em sentido nenhum:

(34a) Arrependeu-se de não o haver matado como quem mata a um reptil, ou outro qualquer bicho nocivo que nos incomoda (ML, p. 163).

Again and again during the day following their unexpected meeting the woman reproached herself for not having killed him as she would JA or JATO or any other predatory beast that menaced her existence or her safety.

Entretanto, não se observa um padrão constante em nenhuma das traduções. A tradução de beast oscila entre termos genéricos nas três traduções, sendo que na de Bandeira além do predomínio de "bicho" aparecem os seguintes termos bem menos evocativos da selvageria:

(35a) Haveria de descompo-lo e insulta-lo no calão da mata por ele tão bem conhecido; agora, porém, limitava-se a ficar sentado fora do alcance de Tantor, e tinha no rosto uma expressão de profundo pesar e compaixão, pois de todas as criaturas da floresta era Tantor a quem mais amava (MB, p, 91).

The actions of Tarzan were peculiar in the extreme. Had Numa, or Sabor, or Sheeta, or any other beast of the jungle been seeking to destroy him, the ape-man would have danced about hurling missiles and invectives at his assailant.

(36a) Era obra da lança de Tarzan. Fôra a arma fabricada pelo homem que matara a enorme alimaria capaz de sobreviver ao ataque de sete leões possantes (MB, p. 77).

Tarzan's spear had done its work. It was the man-made weapon which killed the great beast.

(37a) Exibira apenas o zeloso instinto de posse do animal (MB, p. 54).

He had but exhibited the beast's jealous protective instinct for a possession.

(38a) Nenhum homem ou animal que vagasse no continente selvagem podia rivalizar em astúcia e força com o seu querido esposo (MB, p. 63).

No man nor beast who roamed the savage continent could boast the cunning and the powers of her lord and master.

Nestas duas passagens, a referência ao leão se encontra nas expressões já cristalizadas, sendo que em inglês tanto pode ser king of the beasts, quanto king of the jungle. 
(39a) O cavaleiro aproximou-se. Assustar-se-ia o cavalo com o cheiro do carnívoro e tomaria o freio nos dentes, deixando Werper de novo á mercê do rei dos animais? (MB, p. 104).

At a walk the horseman approached. Would the nervous animal he rode take fright at the odor of the carnivore, and, bolting, leave Werper still to the mercies of the king of beasts?

(40a) O rei dos animaes encarou-a um instante e em seguida caminhou para seu lado (GR, p. 192).

The king of beasts surveyed her for a moment and then walked toward her.

O termo mais frequente no total das três traduções para a tradução de beast é "animal":

(41a) Entre todos os animaes das selvas, á excepção dos de sua própria especie, elle confraternizava apenas com Tarzan (GR, p. 9).

Of all the jungle beasts, except his own kind, he fraternized with Tarzan only.

(42a) - Está morto? Talvez que elle tambem estivesse a caçar "el-fil" e fosse morto pelo enorme animal (GR, p. 10).

"Is he dead? Perhaps he, too, hunted el-fil and was slain by the great beast".

(43a) E assim continuava o homem-macaco, sem se queixar, á maneira dos animaes, esperando allivio a sua situação e sabendo que elle poderia vir sob a fórma da morte (GR, p. 25).

And so the ape-man lay uncomplaining, as is the way of beasts patiently waiting for release, knowing that it might come in the habiliment of death.

(44a) Elles aborreciam Tarzan, assim como aos outros animaes sylvestres, mas achava-se immunizado contra o veneno de seus ferrões, depois de soffrer-lhe, a vida inteira, a inoculação (GR, p. 26).

They annoyed Tarzan as they did the other jungle beasts, but to the poison of their stings he was immune through a lifetime of inoculation.

(45a) Tambem sabia elle que, se Blake sobrevivesse á fome e aos riscos de ser devorado pelos animaes selvagens, o resultado certo seria cahir victimado por uma lançada galla (GR, p. 159).

Also he knew that if Blake survived hunger and the menace of wild beasts he might only live to fall victim to a Galla spear.

Quando o tradutor opta por um vocábulo mais genérico, ele pode lançar mão de adjetivo para ressaltar a especificidade. No texto em inglês já está implícita a ferocidade de beast, mas na tradução, a adoção do hiperônimo demanda um adjetivo para contrastar os dois tipos se animais: 
(46a) - Esse urro de animal feroz partiu do meio do acampamento e no emtanto aqui só existem homens e alguns poucos animaes domésticos (GR, p. 18).

"It came from the midst of the menzil, and it was the voice of a beast, where there are only men and a few domestic animals".

Exatamente o oposto ocorre um pouco mais adiante na narrativa. $\mathrm{O}$ original marca a diferença com dois adjetivos antônimos qualificando o mesmo substantivo, o tradutor, por sua vez, opta por um termo que abarca também a qualidade:

(47a) Rompendo o mattagal, vinha vindo Tantor, o elephante. Fugiam de seu caminho os animaes mansos e as féras (GR, p. 20).

Through the jungle came Tantor the elephant and from his path fled gentle beasts and fierce.

Dos três tradutores, quem menos traduz beast por "animal" é Lobato (14 vezes, contra 43 e 30 dos outros dois), diferentemente de Rangel, que prefere "fera" a "animal"; e de Bandeira, que prefere "bicho". Lobato, por sua vez, pela maneira como edita o texto, poucas vezes mantém a tradução em nível de palavra por palavra:

(48a) Subito a faca de Tarzan desapareceu, mergulhada fundo no coração da fera, cujo corpo moleou, vencido. Tarzan desembaraçou-se do seu abraço e deixou-a cair por terra em convulsões. Destruirá aquele inimigo, mas a pouca distancia levantava-se o outro, o bruto peludo, que, imovel, se limitara a presenciar o combate (ML, p. 17).

Instantly the shaggy black rushed in with drawn knife which it buried in the beast's heart. For a few moments Tarzan retained his hold but when the body had relaxed in final dissolution he pushed it from him and the two who had formerly been locked in mortal combat stood facing each other across the body of the common foe.

(49a) Um golpe violentíssimo desfechado em pleno cranio da fera derribou-a insensivel, no momento exato em que a lamina de Tarzan lhe afuroava o coração (p.11).

A single terrific blow upon the flattened skull of the beast laid him insensible and then as Tarzan's knife found the wild heart a few convulsive shudders and a sudden relaxation marked the passing of the carnivore.

(50a) Pan-at-lee dormiu e sonhou. Sonhou que estava adormecida sob uma grande arvore, numa grota do Kor-ul-grif, c que um animal feroz avançava para ela sem que lhe fosse possivel a fuga. (ML, p. 49).

Pan-at-lee slept-the troubled sleep, of physical and nervous exhaustion, filled with weird dreamings. She dreamed that she slept beneath a great tree in the bottom of the Kor-ul-GRYF and that one of the fearsome beasts was creeping upon her but she could not open her eyes nor move. 
$\mathrm{Na}$ maioria das vezes, a maneira de Lobato condensar do texto impõe uma manipulação da cena modificando a estrutura narrativa:

(51a) Já com os olhos afeitos ao escuro, e sabendo que ma vista tinha o monstro, preparou-se Tarzan para evitar o bote da fera á qual nenhuma criatura viva podia resistir. Pensou em aplicar o processo dos Tor-o-dons - o Whee-oo! mas refletiu logo que as condições variavam muito, além de que o grifo ali encerrado muito provavelmente não era animal afeito a acatar a autoridade de um cavaleiro. As feras roubadas ao seu ambiente natural requintam-se de ferocidade e odio represo (ML, p. 117).

Aware of the poor eyesight of the beast, and his own eyes now grown accustomed to the darkness of the cavern, the ape-man sought to elude the infuriated charge which he well knew no living creature could withstand. Neither did he dare risk the chance of experimenting upon this strange GRYF with the tactics of the Tor-odon In many respects the conditions were dissimilar. Before, in broad daylight, he had been able to approach the GRYF under normal conditions in its natural state, and the GRYF itself was one that he had seen subjected to the authority of man, or at least of a manlike creature; but here he was confronted by an imprisoned beast in the full swing of a furious charge and he had every reason to suspect that this GRYF might never have felt the restraining influence of authority, confined as it was in this gloomy pit to serve likely but the single purpose that Tarzan had already seen so graphically portrayed in his own experience of the past few moments.

(52a) Depois lançou-se sobre o monstro e começou a dar-lhe no focinho com o pau. Tarzan encheu-se de assombro ao ver aquele animalão, que poderia aniquilar o pitecantropo num apice, tremer diante dele como um rafeiro (ML, p. 60).

It walked directly toward the GRYF who moved aside, as though afraid. Tarzan watched intently. The Tor-o-don was now quite close to one of the triceratops. It swung its head and snapped at him viciously. Instantly the Tor-o-don sprang in and commenced to belabor the huge beast across the face with his stick. To the

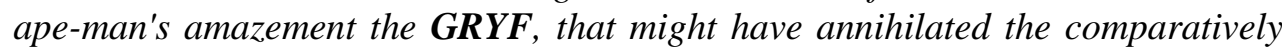
puny Tor-o-don instantly in any of a dozen ways, cringed like a whipped cur.

O monstro dessa história é mencionado 137 vezes no texto fonte e traduzido por "grifo" 84 vezes. Gryf parece ser corruptela de griphon ou griffin, mas nada tem a ver com o ente com cabeça de águia e corpo de leão. A confusão que essa homonímia pode causar é desfeita pela fala de Tarzan na primeira vez que o animal entra em cena:

(53a) - Mal o sinto, apesar de estarmos tão proximos, Pan-at-lee, já ouviu você falar do triceratops? Pois é o nome deste monstro a que chamam aqui grifo, monstro de raça extinta ha milhares e milhares de anos" (p. 57).

"Pan-at-lee, did you ever hear of a triceratops? No? Well this thing that you call a GRYF is a triceratops and it has been extinct for hundreds of thousands of years". 
Outras escolhas menos frequentes para tradução de beast pertencem ainda ao mesmo campo semântico, sendo tanto como hiperônimos quanto hipônimos:

(54a) Descera a paz sobre as cousas e aquelles dois sêres sentiam-se contentes (GR, p. 8).

Peace lay upon the jungle and the two beasts were content.

(55a) Um trovão ribombou longe, no firmamento que se escurecia e os dois entes da selva olharam para cima, para os amplos dominios das forças da Natureza, mais selvagens e destruidoras que as suas próprias (GR, p. 49).

From the darkening sky distant thunder boomed and the two beasts looked upward toward the broad field of Nature's powers, more savage and destructive than their own.

(56a) Toda a atenção do carnívoro parecia agora concentrada no cavaleiro (MB, p. 104).

The beast's whole attention now seemed riveted upon the horseman.

(57a) O leão recuou empinando-se para escorar este novo inimigo. A fera rugia pavorosamente, e eis que aos ouvidos assustados do belga ressoa o mesmo rugido selvagem, saido agora da bôca do homem ao avançar para o felino! (MB, p. 46)

The lion reared up to meet this new enemy. The beast was growling frightfully, and then upon the startled ears of the Belgian, broke a similar savage growl from the lips of the man rushing upon the beast.

(58a) Nos longes da planície um leopardo rugiu, e nos caniços densos da ribanceira outro grande felino deslizou com passadas surdas (MB, p. 61).

Far out across the plain a leopard screamed, and in the dense reeds behind him some great beast moved on padded feet.

(59a) Sabia que o demonio instalado no cerebro astuto e cruel do gigantesco paquiderme haveria de leva-lo a caçar em todos os esconderijos da floresta aqueles que escapassem á violência da primeira arremetida (MB, p. 89).

She knew that the devil in the cunning, cruel brain of the great beast might send it hither and thither hunting through the forest for those who escaped its first charge.

(60a) Stimbol que fôra o espectador dessa scena, suppondo que o homem e o macaco estivessem roncando ameaças um para o outro, estava certo de que ia presenciar nova lucta (GR, p. 37).

Stimbol, who had been watching, was under the impression that the man and the beast were growling at one another and that a new duel impended.

Em algumas outras ocorrências nos textos fontes, onde há a referência a beast, a concisão da língua inglesa força o tradutor a expandir a ideia: 
(61a) Tarzan não sentia grande affeição por Bolgani, o gorilla. Desde creança, o peludo e gigantesco animal de fórma humana fôra o inimigo natural do homemmacaco (GR, p. 34).

In the heart of Tarzan was no great love for Bolgani the gorilla. Since childhood the shaggy, giant man-beast had been the natural foe of the ape-man. His first mortal combat had been with Bolgani.

(62a) Chegaram da selva o rugido de um leão e o urro de um elephante, mas a "boma" que protegia o acampamento era alta e de agudos espinhos, e perto delia havia guardas e fogueiras, para espantar as féras, por isso Tollog não deu attenção áquelles rumores familiares da noite (GR, p. 21).

From the jungle came the roar of a lion and the trumpeting of a bull elephant, but the boma was high and sharp with thorns and there were guards and beast-fire, so Tollog gave no thought to these familiar noises of the night.

Na passagem acima (62a), observa-se ainda o termo "boma". Segundo o OED, é um vocábulo da África oriental e meridional que designa um cercado de proteção contra feras, especialmente para animais ${ }^{152}$. Em português, o Dicionário Houaiss de Língua Portuguesa, edição impressa ${ }^{153}$, não traz o verbete, mas a versão digital de Caldas Aulete ${ }^{154}$ define como: "recinto ao redor das palhotas dos funcionários; fortim (na África Oriental Portuguesa)"; e sua edição de 1925, como "fortim (na África oriental portugueza)". Interessante notar as aspas que o tradutor, Rangel, coloca na palavra talvez para ressaltar o seu caráter inusitado, mesmo sendo uma palavra dicionarizada na época. As aspas não ocorrem na obra de tradução de Bandeira:

(63a) Veio o crepusculo e depois do crepusculo a noite. Uma fogueira ardia dentro do cercado de espinheiros que protegia o acampamento (MB, p. 85).

Dusk came and after dusk came night. A great fire blazed within the little thorn boma about the camp.

(64a) E não tiveram muito que esperar. Um vulto escuro e corpulento pulou dos galhos de uma arvore no interior da boma (MB, p. 187).

Nor had they long to wait. A dim, bulky form dropped lightly from the branches of a tree into the camp.

No primeiro exemplo (63a), o tradutor prefere utilizar a definição e no segundo (64a) ele adota o termo, mesmo ele não constando do texto fonte. Nesse caso, um termo mais neutro, como acampamento, não teria o mesmo valor expressivo. $\mathrm{O}$ uso de palavra tão pouco corrente dá um toque de exotismo e confere autenticidade ao texto. No

\footnotetext{
${ }^{152}$ Noun: (in eastern and southern Africa) an enclosure, especially for animals - origin Kiswahili.

153 Edição de 2014.

154 http://www.aulete.com.br/boma\#ixzz3GiQx2gko Acesso 20/10/2014.
} 
próximo excerto (65a), dois tipos de boma são mencionados; eles correspondem às imagens abaixo:
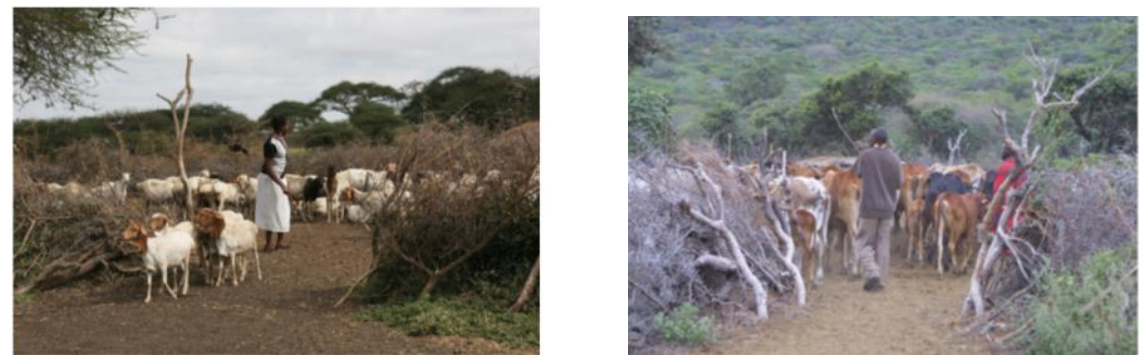

Figura 31: Tipos de boma na África de hoje ${ }^{155}$

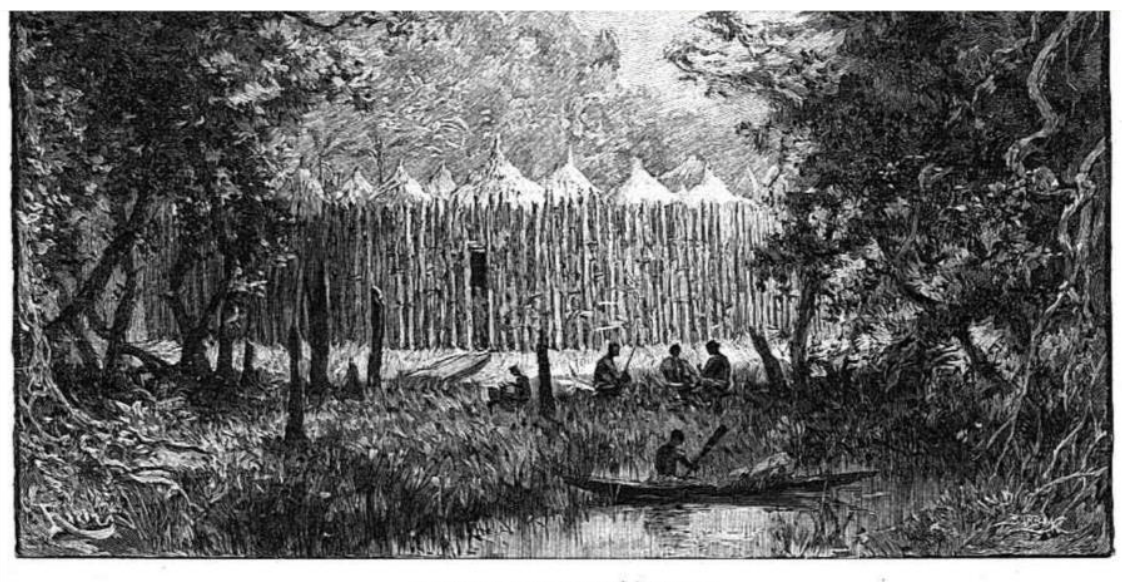

UK S DOYA $\approx$ DANS LES BOTS ' (PAGE 258).

Figura 32: Ilustração que acompanha o artigo da expedição a Katanga do explorador Christian Bonchamps publicada na revista Tour du Monde, Paris, $1892{ }^{156}$.

(65a) Movido por essas solicitações vagas todo-poderosas, o homem-macaco velava uma noite na pequena boma de espinhos que protegia de algum modo a comitiva das depredações dos grandes carnívoros da mata. [...]Por fim levantou-se, silencioso como uma aparição, e aproveitando o momento em que a sentinela waziri lhe dava as costas, galgou rapido a paliçada da boma em face dos olhos chamejantes, saltou sem bulha á galhada de uma grande arvore e desapareceu (MB, p. 16).

Moved by these vague yet all-powerful urgings the ape-man lay awake one night in the little thorn boma that protected, in a way, his party from the depredations of the great carnivora of the jungle. [...] then he rose, noiseless as a wraith, and

\footnotetext{
${ }^{155}$ Fonte: http://lionguardians.wildlifedirect.org/files/2008/05/img 3696.jpg Acesso 20/10/2014.

${ }^{156}$ Fonte: http://collin.francois.free.fr/Le tour_du_monde/Frame7 textes/TdM_frame7.htm Acesso 20/10/2014.
} 
while the Waziri's back was turned, vaulted the boma wall in the face of the flaming eyes, swung silently into a great tree and was gone.

A escolha pelo tradutor da palavra "paliçada" corresponde mais à figura acima e se justifica na medida em que não se trata de uma construção permanente que "parede" ou "muro" poderia sugerir.

Ainda no contexto da selva africana, encontram-se nos textos fontes termos característicos da exuberância da vegetação, que são de difícil correspondência em português. O sentido teria de ser reproduzido utilizando palavras de sentido geral com acréscimos para explicitar a ideia. No caso abaixo, a tradução, além de simplificar a narrativa, cria uma imagem do local diferente da do original: underbrush, que segundo o $O E D$, é formado por vegetação rasteira e pequenos arbustos no solo sob as árvores de uma floresta. A opção do tradutor é "grotão", que se refere a uma grande depressão no solo ou uma região longínqua, esta num sentido mais figurado.

(66a) Mas ao chegar ao termo do grotão viu que o trabalho fora perdido. $\mathrm{O}$ grifo dera volta e havia-se postado lá (ML, p. 59).

Where the underbrush was heaviest, where fallen trees blocked the way, he led the footsteps of the creature below them; but all to no avail. When they reached the opposite side of the gorge the GRYF was with them.

Em outra obra, o tradutor descreve esse tipo de vegetação de três maneiras diferentes. No primeiro trecho, a descrição do portagonista atento ao som do caminhar da fera aproximando leva o tradutor a especificar a vegetação seca:

(67a) Esperava escutar, a cada instante, as pisadas macias e o roçagar de um grande corpo felpudo nos galhos seccos do chão. Os minutos arrastavam-se lentíssimos. Passou-se assim uma hora (GR, p. 176).

Momentarily he expected to hear the fall of padded feet, the sound of a great, furred body approaching through the underbrush. The slow minutes dragged.

(68a) Ao chegar-se mais perto do scenario da perseguição de Bolgani, o gorilla, ouviu o farfalho estalidante do matto rasteiro e vozes de sêres humanos (GR, p. $33)$.

As he approached more closely the scene of the pursuit of Bolgani the gorilla, he heard the crashing of underbrush and the voices of men.

Neste último trecho (68a), exemplificando a tradução de underbrush, o tradutor recorre a uma formação lexical, não dicionarizada, acrescentando um sufixo a "cipoal". As palavras com terminação em -alha não são muito comuns e podem carregar uma conotação pejorativa como: politicalha, gentalha, parentalha. "Cipoalha" pode dar uma 
ideia de crescimento desordenado da vegetação, que tornaria ainda mais difíceis os movimentos de Stimbol, personagem urbana oriunda de Nova York e sem familiaridade com a selva, em contraste com a agilidade de Tarzan.

(69a) Foi esta a scena vista simultaneamente por Stimbol e Tarzan - o primeiro, a tropeçar desasadamente na cipoalha do solo, e Tarzan, semi-deus da floresta, pendendo harmoniosamente de um ramo, entre a folhagem, a meia altura do chão (GR, p. 34).

It was upon this sight that Stimbol and Tarzan came simultaneously-Stimbol stumbling awkwardly through the underbrush, Tarzan of the Apes, demi-god of the forest, swinging gracefully through the foliage of the middle terraces.

Além de underbrush, as três obras trazem outro termo sem correspondente em português que exige criatividade do tradutor, com resultados bastante distintos: terrace. Na passagem acima o sintagma adjetivo + substantivo (middle terraces) é traduzido por uma locução adverbial de lugar. Essa associação de terrace com a vegetação, não se encontra dicionarizada em inglês. Dentre as acepções do $O E D$ para o termo, as mais frequentes são as relacionadas à arquitetura ${ }^{157}$, à agricultura, mais especificamente ao cultivo em regiões escarpadas ${ }^{158}$ e a formações geológicas ${ }^{159}$. No caso a expressão não poderia estar relacionada a uma inclinação do terreno, uma vez que Tarzan "graciosamente se balança através da folhagem". A pesquisa não encontrou esse uso de terrace em outras obras que transcorrem nas selvas como The jungle book, de Kipling, e Heart of darkness de Conrad, donde se depreende que se trata de uma criação de Burroughs.

Pela narrativa conclui-se que terrace é o conjunto de árvores que se divide em três níveis de altura (low, middle e upper). Abaixo, a capa do pirmeiro livro de Tarzan, de publicação americana, pode oferecer uma imagem de como o autor concebia o habitat de Tarzan:

\footnotetext{
${ }^{157}$ A raised level place for walking, with a vertical or sloping front or sides faced with masonry, turf, or the like, and sometimes having a balustrade; esp. a raised walk in a garden, or a level surface formed in front of a house on naturally sloping ground, or on the bank of a river. A row of houses of houses of uniform style, on a site slightly, if at all, raised above the level of the roadway.

${ }^{158}$ Cultivation terrace.

${ }^{159}$ Geol. a horizontal shelf or bench on the side of a hill, or sloping ground.
} 


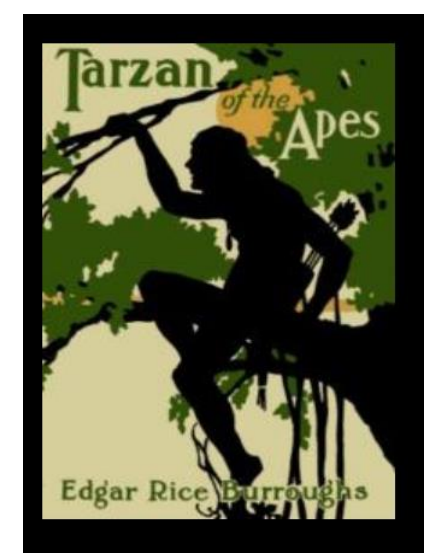

Figura 33: Capa original do primeiro livro da série ${ }^{160}$

Os quatro primeiros fragmentos, a seguir, apesar de serem da mesma obra ( $O$ tesouro de Tarzan) e, portanto, do mesmo tradutor, apresentam soluções muito diversas para essa questão:

(70a) Por algum tempo entregou-se á pura exuberancia do espirito animal, jogando-se perigosamente de um a outro gigante da mata. Depois trepou aos ramos oscilantes e menores da parte mais alta da chapada, onde a lua lhe vinha bater em cheio (MB, p. 17).

For a time in sheer exuberance of animal spirit he raced swiftly through the middle terrace, swinging perilously across wide spans from one jungle giant to the next, and then he clambered upward to the swaying, lesser boughs of the upper terrace where the moon shone full upon him.

Acima, o tradutor elimina a diferenciação de altura e passa do sentido geral do termo em inglês para o mais específico e do coletivo para o individual, primeiramente utilizando uma expressão com sentido figurado (gigante) e, a seguir, com a utilização do nome popular, "chapada", da árvore brasileira Sweetia dasycarpa. Pouco conhecida do leitor não especializado, essa escolha pode levá-lo a entender que se trata da acepção mais comum do termo relacionado à formação de terreno.

Neste trecho, a ideia de níveis de altura diferentes, por onde Tarzan se locomovia, é substiuída pela ausência de luz que há em uma vegetação cerrada.

(71a) Dentro em pouco as emanações do corpo de Bara deram a sentir a Tarzan que a sua presa andava perto. $O$ homem-macaco afundou de novo na escuridão das arvores, de onde poderia apanhar pelo ouvido e pelo olfato o primeiro sinal de contacto com a corça (MB, p. 18). 
Presently the body scent of the deer told Tarzan that his prey was close at hand. It sent him into the trees again - into the lower terrace where he could watch the ground below and catch with ears and nose the first intimation of actual contact with his quarry.

Abaixo, o tradutor considera a mudança de altura, mas ignora a questão da vegetação (72a) e na seguinte (73a), novamente recorre a vocábulos referentes às plantas mais específicos, porém de menor porte que no primeiro trecho analisado. Assim, o ambiente nesses casos é ora entendido como conjunto de grandes árvores, ora de vegetação rala de galhos e cipós:

(72a) Segundos depois, patenteou-se a Tarzan a causa do medo de Bara, com a aproximação do tropel inconfundivel de cavaleiros. Carregando a sua presa para um sitio mais alto, o homem-macaco instalou-se confortavelmente no esgalho de uma arvore, donde podia observar á vontade a trilha em baixo, e cortando uma posta suculenta do lombo da corça, enterrou os dentes fortes e brancos na carne macia, saboreando o fruto da sua força e astúcia (MB, p. 131).

Nor was it long before the cause of Bara's fright became evident to Tarzan, for presently came the unmistakable sounds of approaching horsemen. Dragging his kill after him the ape-man ascended to the middle terrace, and settling himself comfortably in the crotch of a tree where he could still view the trail beneath, cut a juicy steak from the deer's loin, and burying his strong, white teeth in the hot flesh proceeded to enjoy the fruits of his prowess and his cunning.

(73a) Assim os abissinios marcharam para o sul e Tarzan dos Macacos seguiu-lhes na pista, lançando-se silenciosamente, pendurado nos galhos e cipós, de uma arvore a outra (MB, p. 132).

So the Abyssinians and the Belgian marched southward and Tarzan of the Apes swung silently after them through the swaying branches of the middle terrace.

Em $O$ rei da jângal, Rangel se preocupa sempre em estabelecer a diferença de altura da vegetação, conforme pode-se observar em passagem já mencionada e nas seguintes (74a e 75a):

(74a) Subito começou grande estardalhaço nas arvores. Os Manuzinhos e seus irmãos, irmans e primos vinham em louco alvoroço a meia altura das arvores, a guinchar, palrar e xingar.

— Vão pelas pontas altas dos ramos - instou Tarzan. - Nessa altura elles não os podem alcançar. Digam-lhes que um dos seus está amarrado aqui. Digam-lhes que venham soltar-me.

- Temos medo!

— Elles não alcançarão vocês nas pontas altas! Vão, que depois ficarão sendo seus amigos (GR, p. 26). 
Suddenly there came a great scampering through the trees. Little Manu and his brothers, his sisters and his cousins came trooping madly through the middle terrace, squealing, chattering and scolding.

"Go and call to them from the upper terraces," urged Tarzan. "They cannot reach you there. Tell them that one of their people lies helpless here. Tell them to come and release me."

"We are afraid."

"They cannot climb to the upper terraces," said an old monkey. "I will go".

(75a) Cansado de jogar fructas seccas em Numa, Tarzan seguiu pelas arvores, a meia altura das mesmas e repousou á noite já bem longe dalli; de manhan, sentindo o cheiro de Bara, a corça, elle a caçou e comeu (GR, p. 91).

Tired of throwing ripe fruit at Numa, Tarzan swung away through the middle terraces of the forest, lay up for the night far away and in the morning, scenting Bara the deer, made a kill and fed.

Por fim, o termo aparece três vezes no livro traduzido por Lobato, que prefere omiti-lo sistematicamente:

(76a) - Para trás agora, Pan-at-lee! gritou Tarzan, e refizeram com a maior presteza o caminho, vindo de novo ter ao ponto de partida. Inutil. O grifo chegara primeiro (ML, p. 59).

"Back again," said Tarzan, and, turning, the two retraced their high-flung way through the upper terraces of the ancient forest of Kor-ul-GRYF. But the result was the same-no, not quite; it was worse, for another GRYF had joined the first and now two waited beneath the tree in which they stopped.

\subsection{2. b) Além da selva}

Além do cenário da selva africana comum às três histórias, cada uma delas também transcorre em outros lugares. Em $O$ tesouro d e Tarzan, o herói sai em busca de ouro nas ruínas de uma cidade que parece ser Atlândida; em Tarzan, o terrivel, ele chega a uma região perdida na pré-história para salvar Jane; e, finalmente, em $O$ rei da jângal, ele descobre uma cidade medieval em plena África, habitada por cavaleiros cruzados. Na caracterização de cada um desses destinos, Burroughs recorre a um léxico específico.

Em duas histórias analisadas, os antagonistas são árabes nômades em busca de escravos e marfim. A caracterização desse grupo é mais marcada em Lord of the jungle, em cuja narrativa encontram-se estrangeirismos que remetem à cultura árabe. Em The 
jewels of Opar, o léxico relacionado aos árabes pertence ao inglês padrão, à exceção dos nomes próprios, como Achmet Zek e AJbdul Murak:

(1b) Arabes e negros corriam excitados de todas as partes do acampamento para a tenda de seda de Mohammed Beyd, e quando Werper entrou, encontrou grande numero deles em volta do corpo, já frio e inteiriçado (MB, p. 170).

Excited Arabs and blacks were running from all parts of the camp toward the silken tent of Mohammed Beyd, and when Werper entered he found a number of the raiders crowded about the corpse, now cold and stiff.

Em Lord of the jungle, por sua vez, Burroughs lança mão de um grande número de palavras evocativas, sempre em itálico, como se pode observar nesta descrição do acampamento, que remete mais à cultura árabe que o exemplo acima. Todavia, o tradutor não as endossa, optando pela omissão ou por termos genéricos.

(2b) O sheik Ibn Jad, de el-Guad, achava-se sentado de pernas cruzadas no compartimento aberto, destinado aos homens, de sua barraca e a seu lado estava sentado seu irmão Tollog e um joven beduino de nome Zeyd, o qual sem duvida se sentia menos attrahido pela companhia do sheik do que pela proximidade do commodo reservado ás mulheres, commodo que se achava apenas separado daquella especie de sala por uma cortina alta e larga, pendente da travessa central da barraca, o que possibilitava ver-se momentaneamente, ás vezes, a encantadora Ateja, filha de Ibn Jad. Tambem podia-se entrever Hirfa, a mulher deste, vista esta que em nada accelerava o rythmo do coração de Zeyd (p. 11).

The Sheikh Ibn Jad of the fendy el-Guad squatted in the open men's compartment of his beyt es-sh'ar, and beside him in the mukaad of his house of hair sat Tollog, his brother, and a young Beduin, Zeyd, who, doubtless, found less attraction in the company of the sheikh than in the proximity of the sheikh's harem whose quarters were separated from the mukaad only by a breast-high curtain suspended between the waist poles of the beyt, affording thus an occasional glimpse of Ateja, the daughter of Ibn Jad. That it also afforded an occasional glimpse of Hirfa, his wife, raised not the temperature of Zeyd an iota.

Conforme discutido em referências anteriores, Rangel opta por traduzir beyt, que equivale à casa em línguas semíticas, por "barraca". Na passagem acima, a expressão house of hair, que são tendas feitas de pelo de cabra, típicas dos beduínos, é omitida na tradução. Em toda a narrativa em português, o termo mukaad é ignorado, assim como fendy:

(3b) O sheik Ibn Jad, de el-Guard (GR, p. 11)

The Sheikh Ibn Jad of the fendy el-Guad.

(4b) - Já ouvi de uma pessoa de Hazim dizer que um sabio Moghreby foi alli ter, em uma de suas viagens, e consultando os signaes cabalisticos de seu livro de magia, descobriu que em verdade o thesouro alli está (GR, p.13). 
"I had it from one of the fendy Hazim that a wise Moghreby came by there in his travels and consulting the cabalistic signs in his book of magic discovered that indeed the treasure lay there".

Outra escolha por termos neutros que ocorre em todo o texto é relacionada à referência a harém. Como não se trata de problema de falta de correspondente, concluise que Rangel tenha considerado inadequado ao público jovem uma palavra que tem na cultura ocidental uma conotação sexual. As ocorrências do vocábulo (oito no texto fonte) ora são traduzidas por "compartimento das mulheres" como no exemplo (5b) e (6b), ora totalmente modificada em uma versão mais pudica, como em (7b):

(5b) E, dizendo-o, Ibn Jad levantou-se e entrou no compartimento interior (GR, p. 16).

Ibn Jad arose and entered the quarters of his harem.

(6b) O sheik levantou-se e Tollog imitou-o. O primeiro entrou no outro compartimento da barraca, e o ultimo dirigiu-se em silencio, atravez da escuridão da noite, para o lado onde ficava a "hejra" de sua victima (GR, p. 20).

"Good! Now go. The people sleep." The sheikh rose and Tollog, also. The former entered the apartment of his harem and the latter moved silently through the darkness of the night in the direction of the hejra where his victim lay.

(7b) - Meu pae quer que me case com elle, mas não confio nesse homem, e não poderei pertencer a uma pessoa que não me inspira amor nem confiança (GR, p. 17).

"My father wishes me to be of the harem of Fahd, but I mistrust the man, and I could not belong to one whom I neither loved nor trusted".

Bandeira, em sua tradução, não compartilha com o escrúpulo e Rangel e não modaliza o tom, no caso, mais de degeneração dos costumes e da expectativa de horror que sofrerá uma mulher ocidental poderá sofrer em tal situação:

(8b) O que ainda restava de bom na alma de Albert Werper, revoltava-se ao pensamento de vender uma mulher branca para o cativeiro e a degradação de um harem muçulmano (MB, p. 10).

What good remained in Albert Werper revolted at the thought of selling a white woman into the slavery and degradation of a Moslem harem.

(9b) Ela ouvira falar de muitas mulheres, entre as quais mulheres brancas,vendidas por bandidos como Achmet Zek para a escravidão em harens negros ou levadas para o extremo norte e submetidas á existencia igualmente hedionda de algum serralho turco (MB, p. 62). 
She had heard of many women, among whom were white women, who had been sold by outlaws such as Achmet Zek into the slavery of black harems, or taken farther north into the almost equally hideous existence of some Turkish seraglio.

(10b) Disse-me ele que a ela o tinha na conta de protetor e o canalha valeu-se de tal, para ganhar-lhe, a confiança e assim ser mais facil leva-la para o norte afim de vende-la ao harem de algum sultão negro (MB, p. 159).

He has told me that you think him your protector, and he has played upon this to win your confidence that it might be easier to carry you north and sell you into some black sultan's harem.

Outra palavra de origem árabe, askari, não grifada no texto fonte, talvez por ser dicionarizada em inglês com o significado de "soldado" ou "policial", não é mantida por Rangel:

(10b) - Não o sabemos. Elle caçava com um dos nossos. Houve uma grande tempestade. Nenhum deles voltou (GR, p. 93).

We do not know. He hunted with a single askari. There was a great storm. Neither of them ever returned.

Bandeira, por sua vez, reproduz o termo duas vezes sem grifo ${ }^{161}$ :

(11b) No despojo heterogeneo do bando, Achmet Zek arranjou um capacete de cortiça e uma sela europeia, e de entre os seus homens e escravos negros um séquito de carregadores, askaris e armadores de tenda, de molde a formar um modesto safari para um caçador de caça grossa (MB, p. 11).

From a heterogeneous collection of loot, Achmet Zek procured a pith helmet and a European saddle, and from his black slaves and followers a party of porters, askaris and tent boys to make up a modest safari for a big game hunter.

(12b) Agora arranje-me seis carregadores e seis askaris - os mais fortes e mais bravos do safari - e eu marcharei na pista do inglês para descobrir onde ele tem o ouro escondido (MB, p. 15).

Now, give me six porters and six askaris - the strongest and bravest of the safari - and I will march after the Englishman and discover where his gold is hidden."

Mesmo omitindo ou atenuando o sentido dos termos de evocação árabe, Rangel mantém alguns para conferir exotismo e autenticidade ao texto. Normalmente, essas referências aparecem entre aspas:

(13b) — Deixe-me acabar com êlle — disse Fahd desembainhando sua "khusa" (GR, p. 10).

"I will finish him," said Fahd, drawing his khusa.

\footnotetext{
${ }^{161}$ As palavras aqui grifadas em negrito servem somente para destacar a corespondência de termos e não se encontram nos originais.
} 
No próximo exemplo, o tradutor opta por manter um estrangeirismo entre aspas e traduz outros três:

(14b) Que viu o elephante chegar e entrar no acampamento, matar Yemeny e precipitar-se para o lado da "hejra" onde o christão estava. Nesse logar arrancou a "hejra" e projectou Tollog para o ar (GR, p. 24).

He said that el-fil came and entered the menzil, killing Yemeny and rushing to the hejra where the Nasrany lay bound, ripping it aside, throwing Tollog high into the air.

Nasrany é sempre traduzido ao longo da narrativa, mas com relação a menzil o tratamento não obedece nenhum padrão. Logo no início do livro, na primeira menção ao termo, o tradutor o coloca entre aspas e ainda intervém em favor do leitor colocando sua tradução entre parênteses:

(15b) Na floresta, os beduinos Fahd e Motlog caçavam ao norte do «menzil» (acampamento) do sheik Ibn Jad, de el-Guad, em Beni Salem (GR, p. 8).

In the forest Fahd and Motlog, of the tribe el-Harb, hunted north from the menzil of Sheikh Ibn Jad of the Beny Salem fendy el-Guad.

Depois do esclarecimento em parênteses era de se esperar que o tradutor adotasse o estrangeirismo entre aspas, porém não é o que sucede:

(16b) - Esse urro de animal feroz partiu do meio do acampamento e no emtanto aqui só existem homens e alguns poucos animaes domésticos (GR, p. 18).

"It came from the midst of the menzil, and it was the voice of a beast, where there are only men and a few domestic animals".

Outro estrangeirismo que aparece sete vezes no texto fonte traduzido por Bandeira, é kopje. Diferentemente daquelas palavras que evocam a cultura árabe, esta tem origem no holandês kop e por isso designa colina, outeiro. Dicionarizada no $O E D$, passou para o inglês através da língua flamenga falada na África do Sul. Bandeira reproduz askaris, mas traduz kopje por "cabeço", em quase todas as ocorrências à exceção de uma que opta "morro".

(17b) A planicie alastrada de penedos que se estendia da orla do vale a um cabeço de granito, situado fora das muralhas da cidade e onde ficava a entrada do subterrâneo que conduzia á caverna do tesouro, facilitava muito ao belga seguir despercebido Tarzan até Opar (MB, p. 25).

The boulder-strewn plain between the valley's edge and the mighty granite kopje, outside the city's walls, where lay the entrance to the passage-way leading to the treasure vault, gave the Belgian ample cover as he followed Tarzan toward Opar. 
(18b) Deu com a passagem estreita que conduzia ao interior do cabeço por degraus de granito já muito gastos. (p. 26).

He found the narrow cleft leading downward into the heart of the kopje along well-worn, granite steps.

(19b) Enquanto esperava, transportaria ele proprio para o alto do morro a maior quantidade possivel do precioso metal (p. 26).

In the meantime he would carry as much of the precious metal to the summit of the kopje as he could.

(20b) Satisfeito, Tarzan voltou sobre os seus passos, buscando a saida do subterrâneo (MB, p. 26).

Satisfied, Tarzan turned and retraced his steps toward the summit of the kopje.

Nesse último trecho (20b) o tradutor inverte o movimento. Ao invés de Tarzan ir em direção ao plano mais alto, procurando a luz, no texto traduzido, o herói busca deixar o plano mais baixo, a escuridão, para trás.

Ainda com relação à topografia, o texto traduzido por Lobato não tem estrangeirismos, mas um bom número de termos específicos aos quais o tradutor aplica sua criatividade. Em Tarzan o terrivel, o herói saindo da selva encontra-se num terreno muito acidentado. Nesse cenário, muitos são os termos usados para descrever a paisagem, frequentemente acrescidos de um determinante, caracterizando o aspecto quase intransponível da região. Os acidentes geográficos mais frequentes, no texto fonte são: cliff oitenta e duas vezes e morass, vinte e quatro. São variadas as soluções encontradas pelo tradutor.

A começar por cliff que, segundo a definição do $O E D$, é uma parede de rocha íngreme, especialmente à beira do mar. A pesquisa no Compara revelou que a tradução mais usual é "penhasco", seguida por "rochedo", "falésia" e "precipício", todavia, Lobato não opta por nenhum desses vocábulos à exceção de "rochedo", que aparecem duas vezes no texto, uma como tradução para cliff (21.b) e outra para gorge (22.b), que em inglês se refere a um vale estreito e profundo, uma garganta:

(21b) Mas não era coisa facil. Á claridade da lua pôde ver a linha de rochedos a pique interpostos entre o lago e o templo, formando barreira intransponivel (ML, p. 132).

In the moonlight he could see the sheer cliff rising from the water for a great distance along the shore - far beyond the precincts of the temple and the palace - towering high above him, a seemingly impregnable barrier against his return. 
(22b) - E para lá daqueles rochedos vivem os Waz-don, a gente que não reconhece Ko-tan como chefe, observou Om-at apontando (ML, p. 22).

"And here in these gorges live the Waz-don," exclaimed Om-at, "who do not acknowledge that Ko-tan is the ruler over all the Land-of-man".

No exemplo a seguir (23b), a imagem que o tradutor sugere com "recife" remete a uma formação geralmente associada ao oceano. Esse vocábulo determinado por um sinônimo menos comum para fileira, "renque" e complementadospor uma locução de construção meandrosa, resulta em descrição menos objetiva que o original, curiosamente, elaborada por um tradutor que advoga um texto para os jovens "com o mínimo possível de literatura" (LOBATO, 1957b, p. 339):

(23b) A noite caíra sobre a misteriosa Pal-ul-don, com a lua no alto a clarear lacteamente aquele alto renque de recifes já de si alvadios (ML, p. 25).

Night had fallen upon unchartered Pal-ul-don. A slender moon, low in the west, bathed the white faces of the chalk cliffs presented to her, in a mellow, unearthly glow.

Por fim, neste último exemplo (24b), o quadro "pintado" pelo tradutor difere um pouco do original, pois não descreve penhascos fendidos por gargantas repletas de vegetação.

(24.b) De fato; transposta uma chanfradura da pedra, um vale imenso se desdobrava diante dos olhos do observador - todo verdura esmeraldina, num engaste circular de rochas a pique (ML, p. 22).

About the valley the cliffs were occasionally cleft by deep gorges, verdure filled, giving the appearance of green rivers rioting downward toward a central sea of green.

Conforme já mencionado, o tradutor não mantém a mesma tradução para cliff. Nesta ocorrência (25b) utiliza um termo neutro "montanha":

(25b) No terceiro dia detiveram-se diante duma covanca natural, escavada na montanha ao lado duma das torrentes que dela desciam para alimentação da palude. Ali se abrigaram os tres provisoriamente, (ML, p. 18).

On the third day they came upon a large natural cave in the face of a low cliff at the foot of which tumbled one of the numerous mountain brooks that watered the plain below and fed the morasses in the lowlands at the country's edge.

Pode-se observar acima, também, a tradução para o segundo termo mais frequente, morass, que designa uma área pantanosa e é mais literário que os equivalentes marsh e swamp, que aparecem somente três vezes cada no texto fonte. O 
tradutor preferencialmente opta por "palude" e o adjetivo "paludoso", mas também usa "pantanal", cinco vezes e "brejal", duas vezes, como aparecem no mesmo excerto abaixo:

(26b) Deixando a vila encaminhou-se para sudoeste e cruzou, depois de terriveis provações, uma vasta estepe desertica, revestida em toda a extensão de espinheiros densos; penetrou a seguir num distrito onde provavelmente jamais pisara o homem branco e que mesmo entre as tribus vizinhas era lendário. Montanhas escarpadas, platôs donde desciam torrentes rumorosas, vastas planicies e não menos vastos pantanais apresentaram-se diante dos seus olhos - mas tudo lhe ficou inacessivel até que descobriu o ponto unico de passagem através do brejal imenso - uma estreita senda infestada de toda sorte de repteis venenosos. Muitas vezes á noite divisou sombras de monstros semiimersos na palude, que tanto poderiam ser gigantescos repteis, como hipopotamos, rinocerontes ou elefantes (ML, p. 9).

Leaving the village he had made his way toward the southwest, crossing, after the most appalling hardships, a vast waterless steppe covered for the most part with dense thorn, coming at last into a district that had probably never been previously entered by any white man and which was known only in the legends of the tribes whose country bordered it. Here were precipitous mountains, well-watered plateaus, wide p lains, and vast swampy morasses, but neither the plains, nor the plateaus, nor the mountains were accessible to him until after weeks of arduous effort he succeeded in finding a spot where he might cross the morasses-a hideous stretch infested by venomous snakes and other larger dangerous reptiles. On several occasions he glimpsed at distances or by night what might have been titanic reptilian monsters, but as there were hippopotami, rhinoceri, and elephants in great numbers in and about the marsh he was never positive that the forms he saw were not of these.

A descrição em inglês mostra-se mais detalhada que a tradução ligeiramente condensada, todavia, a imagem que evoca é semelhante. Isso ocorre em todo o texto traduzido. Lobato não se prende ao texto fonte e, frequentemente, dá sua própria interpretação:

(27b) Antes de alcançar a planície uma arvore vanguardeira e isolada o seduziu (ML, p. 11).

At its opposite side rose lofty trees - a great forest which suggested to his practiced eye a mighty jungle.

Lofty é usado literariamente como sinônimo de alto/a. Na passagem acima (27b), as altas árvores se transformam em uma só que se destaca, que está na vanguarda. Abaixo, a tradução tem mais a ver com o ângulo de inclinação da montanha e não com sua altura:

(28b) Puseram-se em marcha pela meia encosta da montanha escarpada, ora ameaçados pelos seus selváticos habitantes, ora vislumbrando, dentro das sombras da noite, estranhas formas de monstros desconhecidos (ML, p. 18). 
For several days their way led through the foothills parallel to the lofty range towering above. Often were they menaced by the savage denizens of this remote fastness, and occasionally Tarzan glimpsed weird forms of gigantic proportions amidst the shadows of the nights.

\subsubsection{A descrição da ação}

As narrativas de Tarzan são uma sucessão de acontecimentos onde predomina a ação e cuja descrição coloca um problema inicial para o tradutor: os verbos. A língua inglesa possui verbos que transmitem de maneira precisa a direção do movimento, com ou sem preposição ou advérbio, e também adjetivos formados a partir desses verbos. Outro aspecto típico da sintaxe inglesa é o de transmitir a ideia de movimento com um verbo de sentido mais geral acrescido de preposição. Para reproduzir todo o material semântico em português faz-se necessário recorrer a outros recursos como acréscimos para designar a maneira exata como se dá o movimento, enquanto a direção do movimento pode ser dada por preposição e/ou adjunto averbial.

5.2.3. a) Tarzan se locomove na selva pelos galhos das árvores, como um símio. Esse movimento foi difundido pelo cinema e pelas histórias em quadrinhos, conforme ilustrado abaixo:
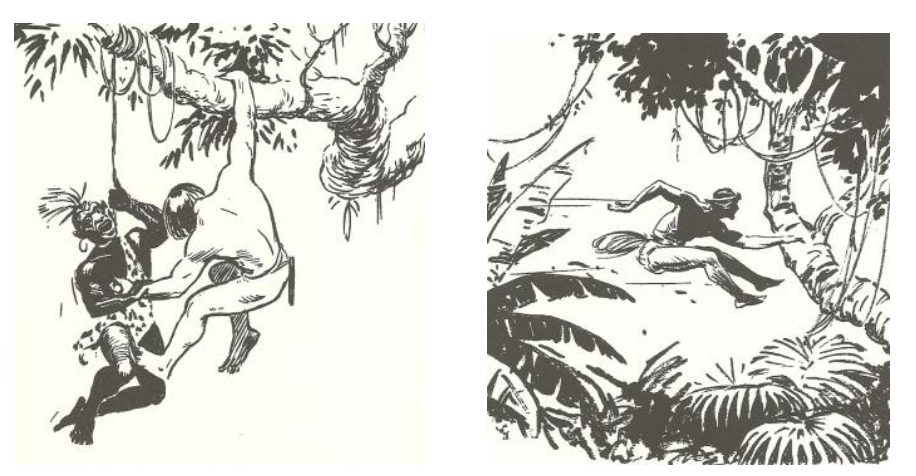

Figura 34: Tarzan de galho em galho. Ilustração de Hal Foster ${ }^{162}$

Esse movimento é descrito, principalmente, pelo verbo swing ${ }^{163}$, definido pelo OED como mover ou provocar o movimento para a frente e para trás e de um lado ao outro enquanto, ou se suspenso. A mesma ideia se repete em sway ${ }^{164}$ só que acrescida do sentido de mover devagar e ritmicamente. São várias as soluções encontradas para

\footnotetext{
${ }^{162}$ Tarzan, Editora Zahar, 2014.

163 move or cause to move back and forth or form side to side while or if suspended.

${ }^{164}$ move or cause to move slowly or rhythmically backwards and forward from side to side.
} 
essas ocorrências, que serão analisadas a seguir. A tradução mais frequente é pelo verbo "balançar". No trecho a seguir, observa-se a meneira como Lobato reescreve o texto. Quanto ao verbo swing, a ideia de estar suspenso está implícito fica subentendido em "cipós":

(1a) Tarzan desceu e meteu-se pela grota, insinuando-se por entre os troncos com a agilidade dos simios, galgando paus caídos, balançando-se em cipós, sempre acompanhado nos calcanhares pela jovem. (ML, p. 136).

He started back again through the trees, swiftly, swinging monkey-like from limb to limb, following a zigzag course that he tried to select with an eye for the difficulties of the trail beneath. Where the underbrush was heaviest, where fallen trees blocked the way, he led the footsteps of the creature below them; but all to no avail.

Abaixo, o tradutor opta pelas preposições "de" e "a" para dar a ideia de deslocamento. O sentido de retorno do Tarzan ao habitat, expressado no advérbio back, não é reproduzido:

(2a) Balançando-se dos cipós de uma arvore a outra, o homem-macaco fez um largo rodeio na floresta e foi sair no rio em outro ponto, onde satisfez a sede (MB, p. 78).

Swinging back through the jungle in a wide circle the ape-man came to the river at another point, drank.

Abaixo, os tradutores optam por verbos que descrevem movimento para a frente, "lançar-se", para baixo, "saltar", "pular" e "precipitar", e para cima "guindar", porém não pendular:

(3a) [...] saltou sem bulha á galhada de uma grande arvore e desapareceu (MB p. 17).

[...] swung silently into a great tree and was gone.

(4a) Werper viu o homem-macaco lançar-se com agilidade pela rocha acima. (MB, p. 25).

He saw the giant ape-man swing himself nimbly up the face of the great rock.

(5a) Assim que Tarzan se poz em pé, o resto do bando feroz e peludo pulou no chão da clareira (GR, p. 28).

As Tarzan came to his feet the balance of the fierce and shaggy band swung into the clearing.

(6a) Com esta advertencia final o homem-macaco guindou-se aos ramos baixos de uma arvore próxima e desappareceu entre a folhagem (GR, p. 52). 
With this final admonition the ape-man swung into the lower branches and was gone.

Nas passagens abaixo, o verbo acrescido da preposição off é bastante dinâmico e sugere deixar o lugar, ação que em parte está contida em "lançar" e "precipitar". Para complementar a perda, um dos traduores opta pelo acréscimo de adjunto adverbial "em fora":

(7a) [...] o homem-macaco limpou as palmas das mãos nas coxas nuas e lançou-se no encalço de Numa (MB, p. 20).

[...] the ape-man wiped his greasy palms upon his naked thighs and swung off in pursuit of Numa.

(8a) Seus pequenos olhos brilharam com um rubro clarão feroz e, no mesmo instante, abalou floresta em fóra, em trote rapido (GR, p. 19).

His little eyes gleamed redly wicked as, a moment later, he swung off through the forest at a rapid trot.

(11a) O homem-macaco riu-se e precipitou-se por entre as arvores na direcção indicada pelos Manus. Não se afastara muito quando começou a sentir fracamente o cheiro deixado pelos pretos; foi acompanhando esse cheiro até ouvir, em dado momento, suas vozes ao longe (GR, p. 92).

The ape-man laughed and swung off through the trees in the direction Manu had indicated. He had not gone far when the scent spoor of blacks came faintly to his nostrils and this spoor he followed until presently he could hear their voices in the distance.

Neste trecho, novamente em inglês, o verbo indica o tipo de movimento e os advérbios a direção. A escolha do tradutor é de utilizar um verbo de sentido mais geral acrescido de locução adjetiva.

(12a) Querendo certificar-se de que suas ordens eram seguidas, Tarzan tomou grande deanteira, indo esperal-os na forquilha de uma arvore pensa sobre a vereda por onde Stimbol devia passar (GR, p. 49).

Tarzan, wishing to assure himself that his instructions were being carried out, had swung far ahead and was waiting in the crotch of a tree that overhung the trail along which Stimbol must pass.

Entretanto, A transmissão do conteúdo semântico de verbo+preposição do texto fonte nem sempre é preocupação do tradutor. Abaixo, a escolha recai sobre um verbo de sentido muito geral: 
(13.a) Cansado de jogar fructas seccas em Numa, Tarzan seguiu pelas arvores, a meia altura das mesmas e repousou á noite já bem longe dalli; de manhan, sentindo o cheiro de Bara, a corça, elle a caçou e comeu (GR, p. 91).

Tired of throwing ripe fruit at Numa, Tarzan swung away through the middle terraces of the forest, lay up for the night far away and in the morning, scenting Bara the deer, made a kill and fed.

Nesta ocorrência a imagem provocada pela tradução difere muito da do original, que descreve os galhos da mata se debruçando sobre o jardim, possibilitando o acesso a Tarzan.

(14a) Melhor seria galgar o muro, coisa simplicissima para um homem-macaco. Alcançou desse modo a zona do templo pelo lado oposto á que tomara na fuga. (ML, p. 114).

He judged that it would not do to attempt again to pass the guard, especially so late at night as it would be likely to arouse comment and suspicion, and so he swung into the tree that overhung the garden wall and from its branches dropped to the ground beyond.

Nas passagens a seguir, encontram-se quatro traduções diferentes para o mesmo verbo em inglês. O Dicionário de Sinônimos e Antônimos Houaiss relaciona os três primeiros - vacilar (15.a), balouçar (16.a) e oscilar (17.a) - como sinônimos no sentido de movimento pendular, que não se expressa com "bambolear" (18.a). Observa-se que nesse trecho o verbo em inglês esse sentido foi intensificado pelo acréscimo da locução adverbial to and fro:

(15a) Tarzan vacilou como o pinheiro augusto que o machado cerceia pela base. Ia cair (ML, p. 42).

For a moment he stood swaying and then like a great pine beneath the woodsman's ax he crashed to earth.

(16.a) Podia deitar-se a fio comprido num galho balouçante, estendendo os membros gigantes e banzando na doce paz de uma despreocupação completa, sem um só cuidado ou apreensão a solapar-lhe a energia nervosa ou roubar-lhe a paz do espirito (MB p, 75).

He could lie at full length along a swaying branch, stretching his giant limbs, and luxuriating in the blessed peace of utter thoughtlessness, without an apprehension or a worry to sap his nervous energy and rob him of his peace of mind. Recalling only dimly any other existence, the ape-man was happy.

(17a) Bem á sua frente, confusamente vislumbrada por entre os troncos e os ramos, estava a molle oscillante de um gigantesco elephante (GR, p. 9);

Directly before him, seen dimly between the boles and through the foliage, swayed the giant bulk of el-fil. 
(18a) Seu desconforme corpanzil bambaleava-se indolente para um e outro lado, quando Tantor, o elephante, preguiçava á sombra do rei das florestas. Naquelles seus dominios elle sentia-se quasi omnipotente (GR, p. 7).

His great bulk swaying to and fro as he threw his weight first upon one side and then upon the other, Tantor the elephant lolled in the shade of the father of forests. Almost omnipotent, he, in the realm of his people.

b) As narrativas em inglês, pelo fato de a história ser ambientada na selva, apresenta muitos verbos específicos relacionados ao movimento de animais. Nas duas primeiras ocorrências (1b e $2 \mathrm{~b}$ ), o verbo slink ${ }^{165}$, que significa mover-se suave e silenciosamente deslizando, é traduzido pelo mesmo tradutor de duas maneiras. $\mathrm{Na}$ primeira ocorrência, ele adiciona um advérbio para reproduzir o conteúdo semântico, mesmo assim nota-se a perda da maneira precisa como a fera caminha: com passos deslizantes, além de furtivamente, suavemente.

(1b) Tarzan viu a grande cabeça abaixar-se, achatar-se para a frente, o corpo agachar-se, a comprida cauda tremer e a fera avançar cautelosamente nessa atitude para o arvoredo do lado oposto (MB, p. 18).

Tarzan saw the great head lower and flatten out, the body crouch and the long tail quiver, as the beast slunk cautiously toward the trees upon the opposite side.

(2b) Uma trilha de elefante, larga e bem batida, levava a clareira á floresta. Numa esgueirou-se paralelamente a ela, enquanto Tarzan deslisava entre o arvoredo como a sombra de um fantasma (MB, p. 20).

A broad, well-beaten elephant path led into the forest from the clearing. Parallel to this slunk Numa, while above him Tarzan moved through the trees, the shadow of a wraith.

Assim como slink o verbo sneak ${ }^{166}$ também subentende o sentido de um movimento subreptício, sem, contudo, insinuar o jeito de caminhar. O advérbio off acrescido a sneak enfatiza a ideia de algo repentino, atribuindo-lhe mais dinanismo. Sem correspondência em português, o tradutor opta por um verbo de sentido mais geral:

(3b) Ficou um momento sem saber o que pensar; dentro em pouco, porém, chegou á conclusão de que Werper, assustado pela aproximação do felino, fugira aterrorizado (MB, p. 71).

For a moment he was puzzled; but presently came to the conclusion that Werper had been frightened by the approach of the lion, and had sneaked off in terror.

\footnotetext{
165 move smoothly and quietly with gliding steps.

${ }^{166}$ move in a furtive or stealthy manner.
} 
A mesma sensação de movimento repentino e rápido se encontra em $\operatorname{dart}^{167}$. No trecho abaixo (4b), o tradutor recorreu ao adjunto adverbial, com perda de conteúdo semântico, pois novamente exclui o sentido correr para um rumo definido:

(4b) Uma figura passou num relance diante de Werper (MB, p. 46).

A figure darted past Werper.

Muitos são os exemplos encontrados nos três livros e, frequentemente, os tradutores optam por um verbo o mais próximo possível do sentido em inglês e fazem acréscimos para expandir a ideia, todavia, em muitos casos, parece não haver a preocupação nesse sentido. No trecho abaixo (5b), o verbo "insinuar" amplia a ideia de thorugh ao significar "infiltrar-se com cautela"; entretanto, o modo de se movimentar rastejando é apagado.

(5b) Tarzan insinuou-se sem medo pela estreita abertura (ML, p. 99).

On hands and knees, he crawled through the small aperture.

A mesma sensação de movimento repentino e rápido se encontra em dart $^{168} \mathrm{e}$ em rush $^{169}$. No trecho abaixo (4.b), o tradutor recorreu ao adjunto adverbial, com perda de conteúdo semântico, pois novamente exclui o sentido correr para um rumo definido. Em (5b) a tradução com um verbo bem corriqueira perde em expressividade.

(4b) Uma figura passou num relance diante de Werper (MB, p. 46).

A figure darted past Werper.

(5b) Deu um passo em direção a uma das entradas, e então estacou, com os olhos arregalados de espanto e terror, pois quasi no mesmo instante uma duzia de portas abriram-se e uma horda de homens terríveis correram para ele (MB, p. 34).

He took a step toward one of the exits, and then he halted, wide-eyed in astonishment and terror, for almost at the same instant a dozen doors opened in the courtyard wall and a horde of a horde of frightful men rushed in upon him.

Muitos são os exemplos encontrados nos três livros e, frequentemente, os tradutores optam por um verbo o mais próximo possível do sentido em inglês e fazem acréscimos para expandir a ideia, todavia, em muitos casos, parece não haver a preocupação nesse sentido. Nos exemplos a seguir, pode-se observar a escolha por

\footnotetext{
${ }^{167}$ run suddenly and rapidly in a particular direction.

168 run suddenly and rapidly in a particular direction.

169 enter hastly.
} 
verbos bastante neutros em expressividade. No trecho (6b) abaixo, o verbo "insinuar" amplia a ideia de through ao significar "infiltrar-se com cautela"; entretanto o modo de se movimentar rastejando é ignorado.

(6b) Tarzan insinuou-se sem medo pela estreita abertura (ML, p. 99).

On hands and knees, he crawled through the small aperture.

Em outro momento o tradutor encontra uma solução mais inventiva do que a citada acima. A locução adverbial "às furtadelas" tem grande valor expressivo, descrevendo uma ação realizada de maneira sorrateira e disfarçada:

(7b) Ao largo, na planície, pastavam numerosos rebanhos de ruminantes selvagens. O homem-macaco rastejou ás furtadelas em direção a um bando de zebras gordas e luzentes (MB, p. 73).

Toward a sleek, fat bunch of zebra he wormed his stealthy way. No intricate process of reasoning caused him to circle widely until he was down wind from his prey -he acted instinctively. He took advantage of every form of cover as he crawled upon all fours and often flat upon his stomach toward them.

Em outros dois trechos, que também descrevem o movimento furtivo de animais, Bandeira faz escolhas que criam imagens totalmente diferentes. Na primeira, o potencial expressivo acha-se não somente no sentido formado por dois adjetivos, mas também na aliteração da letra /s/. Já na segunda, a locução "pés de lã", além da perda de sonoridade, cria a imagem do animal usando pantufas:

(8b) O que seria que atraira a atenção de Numa e o desviara sorrateiro e silencioso da cena na sua derrota? (MB, p. 20).

What was it that had attracted Numa's attention and taken him soft-footed and silent away from the scene of his discomfiture?

(9b) Aproximando-se por uma galhada pendente, o antropoide saltou dentro da boma. Com pés de lã, sem fazer a menor bulha nem mexer uma folha, um capim, chegou-se para perto do homem adormecido, e curvando-se sobre ele pôs-se a examinar-lhe os enfeites (MB, p. 143).

Creeping out upon an overhanging branch the anthropoid dropped to the ground within the boma. He approached the sleeper upon padded feet which gave forth no sound, and with an uncanny woodcraft that rustled not a leaf or a grass blade.

Nesta passagem (10b), novamente o verbo de sentido bem preciso, que cria a imagem do tipo de terreno, acrescido de adjunto adverbial, tem o sentido de avançar tropegamente e de maneira errante. 
(10b) Todo encharcado, a tremer de frio e cheio de furor, Stimbol caminhava na escorregadia e lamacenta vereda. Elle não sabia que seu safari ficara a regular distancia para traz delle, pois o americano fôra sempre andando, ao passo que os pretos, emquanto durara a tormenta, se refugiaram sob as arvores (GR, p. 50).

Soaked with water, cold, furious, Stimbol slopped along the slippery, muddy trail. He did not know that his safari was some little distance behind him, for he had forged ahead during the storm while they had taken refuge beneath the trees.

Outro exemplo bem típico da língua inglesa (11b), um verbo de ação acrescido de advérbio e preposição indicando a direção e também a dinâmica. Uma das acepções do verbo press é de mover-se exercendo pressão ou força. Assim, a cena descrita seria a dos macacos entrando com alguma dificuldade clareira adentro, diferente daquela sugerida pela tradução.

(11b) Ao mesmo tempo em que outros macacos do bando, vendo que M'walat nada soffrera, se aproximavam da clareira, o ultimo se inclinava e, com os fortes dentes cortava a correia de couro de camelo que prendia os pulsos do homemmacaco, fazendo a mesma cousa com a que lhe atava os pés (MB, p. 28).

As the other members of the band pressed forward into the clearing, seeing that M'walat was not harmed, the latter stooped and with powerful teeth severed the camel leather thongs that secured the wrists of the ape-man, and similarly he freed his ankles.

Mais três verbos que descrevem com precisão a maneira de andar (stumble, stride e blunder) são traduzidos por outros bem genéricos ("ir", "marchar" e "caminhar"). Nas duas passagens a seguir, Tarzan está nos subterrâneos da cidade de Opar, em busca do tesouro. Apesar de haver contradição no relato original, que compara o jeito de caminhar facilmente na escuridão como se estivesse em seu habitat, o verbo e a preposição em inglês, blunder through, ressaltam que a falta de luz fazia com que Tarzan fosse tateando e acabasse por cair em um fosso.

(12b) Caminhava nas trevas, como se estivesse atravessando uma planicie aberta ao sol do meio-dia, e subito aconteceu o que tinha de acontecer em tais circunstancias. Chegando á beira do poço, deu um passo para a frente no vacuo, perdeu o equilibrio e precipitou-se nas profundezas do abismo. De lança na mão caiu na agua, mergulhando até o fundo da cisterna (MB, p. 43).

He blundered on through the darkness as though he were traversing an open plain under the brilliance of a noonday sun, and suddenly there happened that which had to happen under the circumstances of his rash advance. move clumsily or if as unable to see. He reached the brink of the well, stepped outward into space, lunged forward, and shot downward into the inky depths below. Still clutching his spear, he struck the water, and sank beneath its surface, plumbing the depths. 
Do mesmo capítulo, a passagem (13b), narra como Tarzan, encontra inesperadamente e num golpe de sorte a sala do tesouro.

(13b) Sem saber, o homem-macaco tinha ido parar na esquecida sala das joias de Opar. (MB, p. 44).

Unwittingly, the ape-man had stumbled upon ${ }^{170}$ the forgotten jewel-room of Opar. stumble - trip or momentarily lose balance.

Em (14b) a tradução não reproduz os passos largos e a maneira decidida de andar numa direção específica.

(14b) Com a majestade senhoril de Numa, o leão, Tarzan marchou em direção ás feras (MB, p. 74).

With all the lordly majesty of Numa, the lion, he strode straight toward the growling beasts.

Outro verbo de movimento que ocorre com bastante frequência nos três originais é wheel, com a acepção de virar rapidamente em direção oposta e/ou virar sobre o próprio eixo. Em português o acréscimo "sobre as patas traseiras" se fez necessário para descrever o mesmo movimento do verbo em inglês, como em (15b) e (16b.):

(15b) Por um instante os animais ficaram imoveis. A lançada cruel arrancou um grito subito de dor e de susto á femea; e ambos depois giraram sobre as patas traseiras e partiram á desfilada (p. 73).

For an instant the two animals stood motionless. The tearing of the cruel barb into her side brought a sudden scream of pain and fright from the mare, and then they both wheeled and broke for safety.

(16b) Não ha dois leões com idênticas características, nem o mesmo leão procede invariavelmente da mesma maneira em circunstancias semelhantes. Fosse surpresa, medo ou cautela que influiu no felino agachado e prestes a saltar sobre o homem, - o fato é que não prosseguiu no seu designio original, e em vez de atacar o adversario, rodou nas patas e desapareceu no mato no momento em que Tarzan se levantou para enfrenta-lo (MB, p. 71).

No two lions have identical characteristics, nor does the same lion invariably act similarly under like circumstances. Whether it was surprise, fear or caution which prompted the lion crouching ready to spring upon the man, is immaterial - the fact remains that he did not carry out his original design, he did not spring at the man at all, but, instead, wheeled and sprang back into the reeds as Tarzan arose and confronted him.

No trecho acima, vale notar que sprang back descreve um movimento mais enérgico, mas a tradução para "desapareceu" é desprovida de força expressiva.

\footnotetext{
${ }^{170}$ find (us.something) by lucky chance.
} 
Em outros trechos, onde esse movimento giratório é descrito com wheel about, que o ato de virar sobre o eixo implica a maneira abrupta da manobra, uma tradução frequente acarreta perda pela escolha de um verbo de sentido mais geral como "voltouse" e "virou-se":

(17b) Por espaço de segundos Tantor ficou a olhar em volta, raivoso, em desafio, e em seguida baixou a tromba, com ella tomou Tarzan do solo, ergueu-o bem alto sobre a cabeça, e, virando-se para traz, atravessou rapidamente o "menzil", em direcção á matta (GR, p. 21).

For an instant Tantor stood looking about, angrily, defiantly, then he reached down and lifted Tarzan from the ground, raised him high above his head, wheeled about and trotted rapidly across the "menzil" toward the jungle.

(18b) Tantor barriu outra vez e, voltando-se para o outro lado, desappareceu na selva. Durante algum tempo o homem-macaco ficou ouvindo distanciar-se as passadas de seu velho amigo (GR, p. 25).

Tantor trumpeted again and, wheeling about, disappeared in the jungle. For a long time the ape-man lay listening to the retreating footfalls of his old friend.

(19b) - Não sou nem escravo nem inimigo, replicou Tarzan. Vim diretamente de Jad-ben-Otho - e espalmou as mãos para mostrar que era de fato duma raça estranha; tambem voltou-se para provar que não tinha cauda (ML, p. 71).

"I come neither as a slave nor an enemy," replied Tarzan. "I come directly from Jad-ben-Otho. Look!" and he held out his hands that the Ho-don might see how greatly they differed from his own, and then wheeled about that the other might see that he was tailless.

Novamente o advérbio away adiciona sentido ao verbo, aqui enfatizando a ideia de deixar o lugar, por isso a opção de acréscimo com outro verbo:

(20b) E, antes que ella pudesse responder, Blake volveu-se e afastou-se; as trombetas haviam soado; e elle trotou lentamente para o logar, na extrema do campo, onde ficavam os pavilhões dos cavalleiros de Nimmr (GR, p. 142).

Before she could reply he had wheeled away, the trumpets had sounded, and he was cantering slowly toward the end of field where the tilts of the Knights of Nimmr stood.

Por fim, na passagem a seguir, o tradutor simplesmente reformula o parágrafo omitindo parte da cena em que está descrito o movimento:

(21b) Werper apalpou a bolsa, tacteando a forma e o tamanho de cada pedrinha. Sentiu o peso do saquinho, primeiro numa das mãos, depois na outra. Por fim despejou o conteúdo na mesa e á luz mortiça da candeia um punhado de gemas faiscantes rolou sobre a madeira tosca (MB, p. 66). 
He hefted the bag, first in one palm, then in the other, and at last he wheeled his chair slowly around before the table, and in the rays of his small lamp let the glittering gems roll out upon the rough wood.

\subsubsection{Além do item lexical}

Após terem sido analisados termos específicos em inglês que são de difícil correspondência em português e sua tradução nos textos alvo, esta seção pretende abordar unidades de tradução mais extensas, envolvendo construções linguísticas de diferentes tipos: expressões idiomáticas, frases feitas, clichês, linguagem figurada etc., que podem apresentar um problema para a tradução, pois poucas vezes há correspondência na língua alvo, e quando há, é necessário que se conheça bem o seu uso na língua fonte e escolher aquele que melhor expresse a ideia, na cultura de chegada. $\mathrm{Na}$ tomada de decisão o tradutor transforma-se em um mediador entre culturas, tendo em mente o seu público alvo.

Burroughs alterna recursos que frequentemente espelham a linguagem coloquial com um nível mais formal, recorrendo a sinônimos mais eruditos, à intertextualidade e à alusão para dar ênfase e/ou acentuar um estilo narrativo. Nas obras traduzidas no Brasil, como os livros da série Tarzan, que eram direcionadas a um público menos letrado e jovem, espera-se no texto alvo uma linguagem mais próxima da fala "comum". Destarte, a análise prosseguirá elencando particularidades nos textos alvos que possam insinuar as estratégias adotadas pelos tradutores para corresponder à proposta editorial $\mathrm{e}$ em que medida elas diferem entre os três textos do corpus.

\subsection{4. a) O tesouro de Tarzan, tradução de Manuel Bandeira}

Na primeira leitura dessa obra, o que causa mais estranhamento é a tradução dos cognatos. Com frequência o tradutor se vê preso ao texto fonte com relação ao léxico, principalmente em razão das palavras de origem latina com sentido parcial no português ou de emprego totalmente diferente. Os motivos dessas escolhas podem ser tanto resultado de desconhecimento das sutilezas da língua inglesa, como fruto de desatenção, ou, até mesmo, para economizar tempo pesquisando outra solução. Com relação às não coincidências dos aparentes homônimos destacamos:

(1a) - É que a sra. não os conhece. Sob aquele exterior selvagem, e a despeito de suas naturezas calejadas e criminosas, existe em cada um deles uma camada indescrutivel de emotividade romantica - encontradiça em toda a parte de 
individuos dessa mesma laia. É o romanesco que atrai os homens a essa vida de crime e banditismo (MB, p. 166).

"You do not know them," he replied. "Beneath their rough exteriors, despite their calloused and criminal natures, there exists in each a well-defined strain of romantic emotionalism - you will find it among such as these throughout the world. It is romance which lures men to lead wild lives of outlawry and crime. The ruse will succeed - never fear".

Segundo o Oxford English Dictionary, a palavra callous tem sua origem na palavra latina callosus, significando pele endurecida, porém no Middle English tardio assumiu o sentido abstrato de insensível, empedernido. A tradução "natureza calejada" aproxima-se da linguagem figurada e da licença poética e distancia-se da linguagem coloquial bastante presente na literatura de entretenimento.

No trecho a seguir a tradução do adjetivo não apresenta problema, pois os adjetivos se equivalem nas duas línguas, com o sentido de exercer uma atração quase impossível de se obter:

(2a) Havia no seu espirito uma sugestão tantalizante de que algo lhe escapava de que ele devia saber muitas coisas que não sabia naquele momento (p. 45).

There was a tantalizing suggestion always present in his mind that something was eluding him -that he should know many things which he did not know.

O substantivo suggestion, por sua vez, tem acepções que nem sempre correspondem ao português "sugestão". Segundo Agenor Soares dos Santos (1983, p. 458): "Suggestion é sugestão [mas] tem alguns matizes em que o cognato português não se usa" e um deles se aplica no contexto acima em que "indício" ou "sinal" expressaria melhor a ideia.

No exemplo abaixo o problema não está no substantivo, mas no verbo:

(3a) Na sua primeira mocidade teria matado o feiticeiro sem o mais leve remorso; a civilização, porém, tinha exercido sobre ele, como sobre as nações e raças a que se estende, o seu efeito amolecedor, embora em Tarzan não chegasse a faze-lo covarde ou efeminado (MB, p. 22).

In his youth he would have slain the witch-doctor without the slightest compunction; but civilization had had its softening effect upon him even as it does upon the nations and races which it touches, though it had not yet gone far enough with Tarzan to render him either cowardly or effeminate.

Novamente o termo pode ser entendido pelo seu sentido concreto ou figurado em inglês. Em português, "amolecer" remete a uma ação física. O gerúndio derivado do verbo soften, além de significar fazer ou tornar menos duro, também quer dizer tornar 
mais brando, enternecer, sensibilizar, ou como o contemporâneo Dicionário Houaiss sugere "amolentador", termo que, no entanto, não está registrado no dicionário de 1925.

Em dois momentos o tradutor cai na armadilha do falso cognato. A acepção mais corrente do adjetivo inglês massive é a de expressar tamanho avantajado; "maciça", por sua vez significa compacto, sólido:

(4a) De repente a cortina sussurrante da vegetação abriu-se a alguns passos do adormecido e a cabeça maciça de leão apareceu (MB, p. 70).

The rustling curtain of vegetation parted a few paces from where the sleeper lay, and the massive head of a lion appeared.

(5a) Werper viu a cabeça maciça virar-se na direção do arabe, e o seu coração quasi cessou de bater, esperando o resultado da interrupção (MB, p. 102).

The Belgian saw the massive head turn in the direction of the raider and his heart all but ceased its beating as he awaited the result of this interruption.

O caso acima é o mesmo do que será analisado a seguir: palavras que percorrem caminhos divergentes desde sua origem comum. Muitas vezes o sentido do cognato é definido pelo seu uso combinado a outro termo (collocation). O adjetivo "ordinário" significa também "comum", como em inglês, ou seja, que não apresenta condição particular. Todavia, quando associado à pessoa predomina a acepção pejorativa de "baixo, grosseiro, mal-educado", como define Houaiss. Em busca no corpus do Compara, as traduções para an ordinary mortal variavam entre "um simples mortal" e "um mero mortal".

(6a) Um branco não seria capaz de seguir vinte passos um rasto feito doze horas antes, um negro te-lo-ia perdido ao cabo da primeira milha; mas Tarzan dos Macacos tinha sido forçado em sua infancia a desenvolver sentidos que um mortal ordinario quasi nunca usa (MB, p. 96).

A white man could not have followed it twenty paces twelve hours after it had been made, a black man would have lost it within the first mile; but Tarzan of the Apes had been forced in childhood to develop senses that an ordinary mortal scarce ever uses.

No trecho a seguir, novamente, o problema está na combinação do adjetivo com o substantivo (collocation):

(7a) A medida que Tarzan dos Macaco avançava através da floresta, os sons discordantes da batalha entre os abissínios e os leões chegavam-lhe cada vez mais distintamente aos ouvidos, não deixando nenhuma duvida sobre a situação critica em que se encontrava o elemento humano empenhado no conflito (MB, p. 191). 
As Tarzan of the Apes hurtled through the trees the discordant sounds of the battle between the Abyssinians and the lions smote more and more distinctly upon his sensitive ears, redoubling his assurance that the plight of the human element of the conflict was critical indeed.

Em inglês discord tem o mesmo sentido de discordar do português, mas a equivalência para por aí. A palavra tem na língua inglesa a acepção de contraste, diferença e oposição e associada a sons significa som desagradável, confuso, cujo termo musical correspondente seria som dissonante.

Em outros momentos, apesar de não haver divergência de sentido com relação aos cognatos, essa maneira "literal" de traduzir soa artificial e pouco fluente.

(8a) Relanceou os olhos em torno, como a procurar a forma tangível de uma excusa legítima para o seu crime; mas nada encontrou senão o corpo do homem que matara tão sem motivo (MB, p. 6).

What was he to do? He glanced about as though searching for the tangible form of a legitimate excuse for his crime; but he could find only the body of the man he had so causelessly shot down.

(9a) O belga consumia dois dias em completar os preparativos. Finalmente partiu com o seu safari, acompanhado por um só guia waziri que Lord Greystoke lhe emprestou. (MB, p. 14)

The Belgian consumed two days in completing his preparations, but finally got away with his safari, accompanied by a single Waziri guide whom Lord Greystoke had loaned him.

(10a) Ia a esmo - para diante, para diante, gozando da liberdade sem peias dos movimentos, na esperança de deparar com algum vestigio de Chulk ou dela, incentivo secundario (MB, p. 175).

His direction was aimles -he merely raced on and on through the jungle, the joy of unfettered action his principal urge, with the hope of stumbling upon some clew to Chulk or the she, a secondary incentive.

(11a) Ignorante do verdadeiro carater do homem, Jane Glayton nada desconfiou dos planos dele ou da especiosa explicação das relações anteriores com o arabe. Por isso aceitou com entusiasmo o oferecimento de Werper, partindo com ele rumo ao acampamento onde tão recentemente estivera prisioneira (MB, p. 154).

Unsuspicious of the man's true character, Jane Clayton saw nothing peculiar in his plans, or in his specious explanation of his former friendship for the raider, and so she grasped with alacrity the seeming hope for safety which he proffered her, and turning about she set out with Albert Werper toward the hostile camp in which she so lately had been a prisoner.

Por vezes a tradução tem um resultado tão artificial que se torna difícil a visualização da cena e o sentido só pode ser entendido devido ao contexto: 
(12 a) Os arabes carregaram repetidas vezes, formando afinal uma circunferencia estacionaria perto da pequena fortaleza e fora do alcance das flechas dos defensores (MB, p. 40).

Again and again the Arabs charged, at last forming a stationary circle about the little fortress, and outside the effective range of the defenders' arrows.

(13a) Tarzan encontrou dificuldade em manter o espirito dos companheiros aplicado ao fim que tinham em vista, pois o espirito de um macaco carece de força de concentração sustentada (MB, p. 116).

Tarzan found difficulty in keeping the minds of his fellows set upon the purpose of their adventure, for the mind of an ape lacks the power of long-sustained concentration.

A literalidade na tradução também acontece com relação às expressões idiomáticas. Bandeira, na expressão que significa o período mais escuro e quieto da noite, parece não reconhecer de que se trata de linguagem figurada, que não pode ser entendida no sentido de cada palavra de maneira isolada, mas na sua relação com outras:

(14a) Foi coisa muito demorada varar a floresta pela noite morta atras do belga (MB p. 190).

It was slow work pushing through the jungle in the dead of night behind the slowmoving Belgian.

Conforme mencionado anteriormente, os textos de Burroughs, mesmo não sendo considerados de valor literário, apresentam elementos que elevam o registro da linguagem. Bandeira, nesse caso, prefere não lançar mão do recurso expressivo e opta por termos literais, com o primeiro com um substantivo, que designa a total ausência de luz, mas que também remete ao inferno.

(15a) Riscando uma porção de fosforos, o belga conseguiu acha-la, e quando, um momento depois, os raios mortiços espancaram as trevas em torno, ele deu um suspiro nervoso de alivio, pois a escuridão impenetrável acentuara os terrores da sua situação (MB, p. 29).

A moment later, the sickly rays relieved the Stygian darkness about him, he breathed a nervous sigh of relief, for the impenetrable gloom had accentuated the terrors of his situation.

Na expressão, de forte evocação poética, o adjetivo Stygian refere-se ao rio subterrâneo da mitologia grega, "Styx", por onde eram transportadas as almas penadas. 
Linguagem figurada, que assume relevo para significar "muito escuro", foi utilizada por muitos poetas, incluindo John Milton em Paradise Lost:

\section{Book I}

With stench and smoak: Such resting found the sole Of unblest feest. Him followed his next Mate, Both glorying to have scap't the Stygian flood As Gods, and by thir own recover'd strength, Not by sufferance of supernal power. [240] ${ }^{171}$

Interessante notar que tanto o texto fonte quanto o texto alvo oscilam entre o formal e o coloquial, mas a tradução não obedece a uma correlação no registro de linguagem. Nas passagens a seguir, o tradutor apela para expressões coloquiais quando o original tem um tom mais neutro.

(16a) Mugambi aguardou. Estava com a pulga na orelha (MB, p. 64).

Mugambi waited. His suspicions were aroused.

(17a) Na manhã seguinte Abdul Murak ficou danado da vida ao descobrir que o latagão do preto fugira durante a noite (MB, p110).

The following morning Abdul Mourak was enraged and chagrined to discover that this huge, black prisoner had escaped during the night.

(18a) - Está louco? perguntou. — Imagina então que as sentinelas darão credito a semelhante balela? (MB, p. 166).

"Are you quite mad?" she asked. "Do you imagine that the sentries will credit any such ridiculous tale?"

(19a) Quando Werper balbuciou uma geringonça ridicula qualquer em resposta, a curiosidade do homem não se conteve mais e ele adiantou-se perguntando que lingua era aquela que estavam falando (MB, p. 160).

When Werper mumbled some ridiculous jargon in reply his curiosity broke bounds, and he stepped forward, demanding to know what language it was that they spoke.

Entretanto, os exemplos em sentido contrário, de termos menos eruditos no texto fonte para termos mais literários no alvo, são mais frequentes:

${ }^{171}$ Fonte: $\underline{\text { https://www.dartmouth.edu/ milton/reading_room/pl/book_1/text.shtml }}$ 
(20a) [...] grandes blocos de granito desprendidos do teto rolaram no corredor angusto, entupindo-o, e os muros penderam para dentro sobre o entulho (MB, p. 29).

[...] the tortured sides of the narrow passageway split and crumbled, great blocks of granite, dislodged from the ceiling, tumbled into the narrow way, choking it, and the walls bent inward upon the wreckage.

(21a) O peso do corpo do homem fe-la esbarrondar-se por terra (MB, p. 130).

The weight of the man's body carried the deer to the ground.

(22a) Tentar arranca-lo do meio dos cavalos armados era coisa que Tarzan não faria senão em ultimo recurso, pois o animal selvagem age sempre com astucia e cautela, a menos que seja açulado pela dor ou pela colera (MB, p. 132).

To endeavor to snatch him from the midst of the armed horsemen, not even Tarzan would attempt other than in the last extremity, for the way of the wild is the way of caution and cunning, unless they be aroused to rashness by pain or anger.

(23a) Achmet Zek esporeou o cavalo e precipitou-se sobre os abissínios. Atrás dele galopou, agitando as carabinas acima das cabeças, urrando e praguejando, a horda variegada dos seus fascinoras (MB, p. 133).

Achmet Zek put spurs to his horse and dashed down upon the Abyssinians, and after him, waving their long guns above their heads, yelling and cursing, came his motley horde of cut-throat followers.

(24a) Os dedos do belga tentavam agarrar o gasnete do arabe (MB, p. 162).

The Belgian's fingers were feeling for his throat.

(25a) Werper entrou, encontrou grande numero deles em volta do corpo já frio e inteiriçado (MB, p. 170).

Werper entered he found a number of the raiders crowded about the corpse, now cold and stiff.

(26a) Quando finalmente atravessaram o jardim talado e pararam em frente ás ruinas carbonizadas da casa do patrão, viram transformados em convicções á luz da evidencia, os seus peores receios (MB, p. 57).

When, at last they crossed the trampled garden and stood before the charred ruins of their master's bungalow, their greatest fears became convictions in the light of the evidence about them.

(27a) Um filhote nedio recompensou a meia-hora de tocaia e o bote subito e selvagem (MB, p. 173).

A fat yearling rewarded a half hour of stealthy creeping and a sudden, savage rush.

(28a) Gritando de pavor, o soldado enfiou o fracos dedos na juba enorme, tentando afastar de si a queixada hiante (MB, p. 186). 
Shrieking out his terror, the soldier clawed with puny fingers at the shaggy breast in vain endeavor to push away the grinning jaws.

(29a) Os leões penetraram no acampamento - conheço pelo rincho dos cavalos. Estás ouvindo? O grito de um homem nas vascas da morte! (MB, p. 191).

The lions are attacking them--they are in the camp. I can tell from the screams of the horses - and there! - That was the cry of a man in his death agonies.

(30a) A caça foi um sucesso, e dez dias depois da abertura, um safari carregado de opimos despojos se punha de volta á planicie waziri. (MB, p. 196)

In itself the hunt was a success, and ten days after its inauguration, a well-laden safari took up its return march toward the Waziri plain.

No nível sintático o texto traduzido, em algumas passagens, apresenta construções expressivas. A estilística da frase advoga que a criatividade reside na "dupla escolha do padrão sintático e do léxico" (MARTINS, 2003, p. 129). Muitos trechos na tradução de Bandeira apresentam opções que remontam à manifestação poética.

O longo período abaixo se distancia do estilo modernista da frase curta, entrecortada e incisiva, muitas vezes encontrado na obra de Bandeira, mas são exatamente essas orações, que se sucedem coesas pelo campo semântico, que exprimem a calmaria e a quietude do momento.

(31a) Sonhara com o poder, com prazeres e luxos que haviam ficado sempre fora do seu alcance, e nesses devaneios levantou o olhar da mesa, fitando-o no vazio, como faz sonhador absorto que contempla em pensamento o alvo longinquo acima do horizonte mesquinho das trivialidades terrestres (MB, p. 67).

He dreamed of joys and luxuries and power which always had been beyond his grasp, and as he dreamed his gaze lifted from the table, as the gaze of a dreamer will, to a far distant goal above the mean horizon of terrestrial commonplaceness.

Na passagem abaixo, tem-se a impressão de uma câmera de cinema que vai fechando o quadro até penetrar na mente da personagem. A inserção da pergunta retórica faz com que o narrador se confunda com Tarzan, não obstante o uso da terceira pessoa. Além disso, referir-se a si mesmo pelo nome caracteriza a mente simples e infantil do protagonista que neste momento havia voltado à condição animal devido a uma batida na cabeça.

(32a) Um sorriso de escarnio arreganhou os dentes de Tarzan ao refletir no ato do homem - o abandono de um camarada no momento de perigo e sem aviso. Ora bem, se Werper era desses, Tarzan não queria mais saber dele. Fora-se? Pois que ficasse por lá - pouco importava a Tarzan e Tarzan não daria um passo para descobri-lo (MB, p. 71). 
A sneer touched Tarzan's lips as he pondered the man's act - the desertion of a comrade in time of danger, and without warning. Well, if that was the sort of creature Werper was, Tarzan wished nothing more of him. He had gone, and for all the ape-man cared, he might remain away-Tarzan would not search for him.

Os dois excertos abaixo apresentam repetição intencional, que Norma Goldstein (2005, p. 14) aponta como um dos quatro traços marcantes da poética de Bandeira nos seus três primeiros livros, ao lado da antítese, das imagens sensoriais e da ternura pelo tema. Nesta primeira passagem, a reiteração da palavra "esquecido", realçada pelo uso de travessão e aliada às orações coordenadas do período seguinte, realçam e intensificam o momento de espanto da heroína.

(33a) Jane arregalou os olhos de espanto incredulidade, ao contemplar aquela aparição que parecia surgir do imperio dos mortos. O leão foi esquecido esquecido o próprio perigo - esquecido tudo, salvo o milagre espantoso daquela ressurreição. Com os lábios entreabertos, as mãos espalmadas contra o peito ofegante, a moça inclinava-se para a frente, olhando como fascinada pela visão do companheiro que julgava morto (MB, p. 192).

Wide went her eyes in wonder and incredulity, as she beheld this seeming apparition risen from the dead. The lion was forgotten - her own peril everything save the wondrous miracle of this strange recrudescence. With parted lips, with palms tight pressed against her heaving bosom, the girl leaned forward, large-eyed, enthralled by the vision of her dead mate.

Se no trecho acima o efeito estilístico realiza-se na repetição lexical, neste a seguir a repetição é estrutural. As orações coordenadas alternativas dão realce à personalidade paradoxal da sacerdotisa. A inversão da oração inicial põe em relevo a ambiguidade da personagem e a segmentação da oração pelo pronome "essa" põe em relevo ambas as partes e salienta o valor do sujeito como tema.

(34a) Estranha criatura era essa La de Opar, dividida assim entre emoções que se contrariavam. Ora sacerdotisa cruel e sedenta de sangue servindo ao culto de um deus barbaro, ora mulher de coração amolecido em compaixão e ternura. Já encarnando o ciume e a vingança, já soluçando compassiva e generosa; lubrica e virginal ao mesmo tempo; mas sempre mulher. Assim era La (MB, p. 93).

A strange anomaly was La of Opar - a creature of circumstance torn by conflicting emotions. Now the cruel and bloodthirsty creature of a heartless god and again a melting woman filled with compassion and tenderness. Sometimes the incarnation of jealousy and revenge and sometimes a sobbing maiden, generous and forgiving; at once a virgin and a wanton; but always - a woman. Such was La.

Também na oração a seguir a ordem direta é alterada a fim de produzir efeito estilístico. Assim, o sujeito posposto ao verbo atrai a atenção para a personagem. No 
período, há outra inversão que causa estranheza na primeira leitura. Ao deslocar o complemento do objeto indireto - ao transporte inseguro proporcionado pelo pônei árabe - e antepô-lo ao direto - o balanço nos cipós da mata - o tradutor realça a natureza símia de Tarzan.

(35a) Aí ouviu ele os disparos dos duelistas, e preferindo ao transporte inseguro proporcionado pelo pônei arabe, o balanço nos cipós da mata, atirou-se ás arvores (MB, p. 138).

Here he heard the occasional shots of the duelists, and choosing the safer and swifter avenue of the forest branches to the uncertain transportation afforded by a half-broken Abyssinian pony, took to the trees.

Algumas escolhas do tradutor revelam-se ideológicas, como por exemplo, as referências às mulheres que são modalizadas na tradução. Nesta passagem, a hierarquia entre marido e mulher estabelecida no original é amenizada por uma relação mais romântica:

(36a) Nenhum homem ou animal que vagasse no continente selvagem podia rivalizar em astucia e força com o seu querido esposo (MB, p. 63).

No man nor beast who roamed the savage continent could boast the cunning and the powers of her lord and master.

No trecho abaixo, em um contexto em que animais e humanos coexistem em condições de quase igualdade, Tarzan em sua persona selvagem, se refere à sacerdotisa como "esta fêmea" (this she). Esta demonstração do desprezo de Tarzan pela mulher que diz amá-lo não é reproduzida na tradução:

(37a) Vamos embora. Senão ela te mata e não me deixa sair daqui (MB, p. 49).

This SHE would kill you and keep me for herself.

Alguns sinais tipográficos são recursos utilizados na tradução que podem expor a estratégia do tradutor. Nos três excertos a seguir, os três termos foram transpostos exatamente do inglês para o texto em português entre aspas, o que marca uma presença do tradutor, pois confere um aspecto estrangeiro do texto que não se acha presente no original. Nenhum dos termos - bluff, ring, maelstrom - se achava dicionarizados na época e atualmente encontram-se somente dos dois primeiros como empr'stimo, mas uma tradução por alguma correspondente seria possível.

(38a) Não passava aquilo uma exibição de um "bluff" da mata. (MB, p. 76). 
It was purely an exhibition of jungle bluff.

(39a) Tarzan acompanhava de palanque aquela batalha real com o mais vivo interesse, pois os bichos mais inteligentes da mata interessavam-se muito por tais encontros. Estes são para eles o que são para nós o "ring", o teatro e o cinema (MB, p. 77).

From the safety of his perch Tarzan watched the royal battle with the keenest interest, for the more intelligent of the jungle folk are interested in such encounters. They are to them what the racetrack and the prize ring, the theater and the movies are to us.

(40a) O homem-macaco tornou-se o centro de um "maelstrom" horroroso de safanões, golpes e dentadas (MB, p. 82).

Instantly the ape-man became the center of a whirling, striking, biting maelstrom of horror.

O vocábulo a seguir não se achava e não se acha dicionarizado e tampouco foram encontradas ocorrências no programa Compara, o que leva a crer que se trata de um neologismo muito a gosto dos modernistas. Outra hipótese seria a de um erro tipográfico, pois conforme já mencionado, era frequente em publicações de menor custo da época.

(41a) Os sacerdotes agruparam-se argumentando e discutindo. Batiam com os punhos nos peitos; levantavam as mãos e os olhos para o deus sinistro; remoneavam entre si (MB, p. 94).

The priests gathered together in a little knot arguing and discussing. They pounded upon their breasts with their fists; they raised their hands and eyes to their fiery god; they growled and barked among themselves.

\subsection{4. b) Tarzan, o terrível, tradução de Monteiro Lobato}

Conforme já observado o traço mais característico da tradução de Lobato é a condensação, que pode ter sido motivada tanto pela padronização da coleção, como pela maneira com que Lobato entendia o ato de traduzir. Muito já se falou sobre a convergência do pensamento de Lobato com relação à tradução e à sua própria literatura. A percepção de que as obras deveriam ser simples e fluentes, "estilo água de pote", tinha como objetivo tornar mais fácil o acesso do leitor à obra, assim o que mais se destaca na sua tradução são as escolhas diferentes em nível estrutural. Normalmente essas diferenças não denotam mudança ao nível das ideias, mas geram dois textos distintos, pois a estrutura do texto definirá a sua própria identidade. 
Essa estratégia tradutória ocorre de diferentes maneiras. Uma delas é a opção por quebrar um período longo em orações justapostas, condensando a descrição:

(1b) Na aparência sem tantas cautelas, seguia na sua frente a caça, e embora caminhasse tão em silencio como o leão não evitava as manchas de luar. Era um animal de atitude erecta, firme sobre dois pés e de corpo glabro; tinha os braços musculosos e bem feitos, as mãos com longos dedos e as pernas tambem de boas proporções; já os pés se afastavam do tipo clássico dos pés humanos — os dedos grandes protuberavam em excesso e afastavam-se uns dos outros (p. 7).

Apparently less cautious was the hunted thing moving even as silently as the lion a hundred paces ahead of the tawny carnivore, for instead of skirting the moonsplashed natural clearings it passed directly across them, and by the tortuous record of its spoor it might indeed be guessed that it sought these avenues of least resistance, as well it might, since, unlike its grim stalker, it walked erect upon two feet-it walked upon two feet and was hairless except for a black thatch upon its head; its arms were well shaped and muscular; its hands powerful and slender with long tapering fingers and thumbs reaching almost to the first joint of the index fingers. Its legs too were shapely but its feet departed from the standards of all races of men, except possibly a few of the lowest races, in that the great toes protruded at right angles from the foot.

(2b) Tinham caudas ambos, mas só um apresentava o corpo revestido de pêlos, e quanto á linguagem era certo possuirem-na bastante desenvolvida. E tambem conheciam a escrita. Esses indices de alto desenvolvimento biologico em seres ainda dotados de apendice caudal acirravam o empenho de Tarzan em senhorearse daquele dialeto, unico meio de penetrar mais a fundo no mistério. Daí sua aplicação (ML, p. 19).

Here were men with the tails of monkeys, one of them as hair covered as any furbearing brute of the lower orders, and yet it was evident that they possessed not only a spoken, but a written language. The former he was slowly mastering and at this new evidence of unlooked-for civilization in creatures possessing so many of the physical attributes of beasts, Tarzan's curiosity was still further piqued and his desire quickly to master their tongue strengthened, with the result that he fell to with even greater assiduity to the task he had set himself.

Além de intervir na sintaxe, o tradutor muda o foco narrativo, sumarizando uma longa ideia em afirmações do seu ponto de vista (nos excertos abaixo em negrito), colocando-se como um narrador intruso, que analisa e comenta sem neutralidade:

(3b) Parecia uma luta cegamente brutal onde a inteligencia ou a manha nada tivesse que ver e, no entanto cada musculo do homem-macaco obedecia a ordens dum cerebro de longa experiencia e treino em tal sorte de lutas. Suas poderosas pernas, aparentemente embaraçadas pelas patas trazeiras da fera, escapavam-lhe das garras aduncas sempre no instante preciso. Parecia aquilo um milagre (ML, p. 17).

Seemingly the attack was one of mad, senseless ferocity unguided by either reason or skill. Nothing, however, could have been farther from the truth than such an assumption since every muscle in the ape-man's giant frame obeyed the dictates of the cunning mind that long experience had trained to meet every exigency of such 
an encounter. The long, powerful legs, though seemingly inextricably entangled with the hind feet of the clawing cat, ever as by a miracle, escaped the raking talons and yet at just the proper instant in the midst of all the rolling and tossing they were where they should be to carry out the ape-man's plan of offense. So that on the instant that the cat believed it had won the mastery of its antagonist it was jerked suddenly upward as the ape-man rose to his feet, holding the striped back close against his body as he rose and forcing it backward until it could but claw the air helplessly.

(4b) Dois meses de pesquisas naquele Mundo Fechado não revelaram nenhum indicio de que lady Jane houvesse penetrado nele; mas das suas investigações pelas tribus circundantes Tarzan se convencera de que, se ela vivia, só naquela zona poderia achar-se, porque só pelo pantanal a fuga teria sido possivel. Mas como pudera ela atravessar o pantanal? Impossivel conceber isso - e no entanto algo lhe sussurrava que Jane o atravessara e só naquele distrito podia ser encontrada. A area desconhecida dos homens era imensa e bloqueada de montanhas inacessiveis, com torrentes impetuosas que até a uma criatura como Tarzan assustavam - e havia alem desses óbices a defesa tremenda dos grandes carnivoros rondantes (ML, p. 10).

The true lions of this new Old World differed but little from those with which he was familiar; in size and conformation they were almost identical, but instead of shedding the leopard spots of cubhood, they retained them through life as definitely marked as those of the leopard. Two months of effort had revealed no slightest evidence that she he sought had entered this beautiful yet forbidding land. His investigation, however, of the cannibal village and his questioning of other tribes in the neighborhood had convinced him that if Lady Jane still lived it must be in this direction that he seek her, since by a process of elimination he had reduced the direction of her flight to only this possibility.

(5b) - Aqui vejo impressos no chão todos os hieroglifos do drama (ML, p. 39).

[...] "look, you can see where his four paws left their impress in the turf as he checked his charge upon the very verge of the abyss".

No trecho a seguir, o narrador interrompe o fluxo da história e fala na primeira

pessoa do plural apelando para a memória do leitor sobre a invencibilidade de Tarzan:

(6b) Tarzan aproximou-se, afastou a pele de leão, espiou. Era o momento em que O-lo-a se debatia nas unhas de Bu-lot, cuja perna Pan-at-lee agarrava. Tarzan viu $\mathrm{Bu}$-lot jogar ao chão a princesa e, louco de colera erguer a faca para destruir Panat-lee. Sua mão, porém, foi detida no ar. O resto já sabemos. Quando Bu-lot caíu, as duas mulheres imediatamente reconheceram seu salvador (ML, p. 133).

At the moment that Tarzan lifted the hangings, the warrior threw $O$-lo-a viciously to the ground and seizing Pan-at-lee by the hair drew his knife and raised it above her head. Casting the encumbering headdress of the dead priest from his shoulders the ape-man leaped across the intervening space and seizing the brute from behind struck him a single terrible blow. As the man fell forward dead, the two women recognized Tarzan simultaneously.

A mudança do foco narrativo também ocorre em outras passagens do discurso direto para o discurso indireto, onde o tradutor narra o que uma personagem falou: 
(7b) Um velho guerreiro declarou que ninguem melhor que Om-at poderia responder, visto como ele estava na propria caverna de Pna-at-lee. Quanto ao pai e irmãos, tinham sido destacados para atalaia longe dali. Uma coisa, entretanto, prosseguiu o velho, causava especie aos querreiros da tribu, e era que Om-at, novo chefe de Kor-ul-ja, tivesse junto de si a um HO-don, a raça eternamente inimiga e tambem áquele homem sem cauda. Era necessario que o novo chefe entregasse os intrusos ao povo para que fossem justiçados (ML, p. 34).

An old warrior spoke. "Pan-at-lee should be in her cave. Who should know that better than you who are there now? Her father and her brothers were sent to watch Kor-ul-lul; but neither of these questions arouse any tumult in our breasts. There is one that does: Can Om-at be chief of Kor-ul-JA and yet stand at bay against his own people with a Ho-don and that terrible man at his side-that terrible man who has no tail? Hand the strangers over to your people to be slain as is the way of the Waz-don and then may Om-at be gund".

(8b) Dois jovens guerreiros chegaram até á abertura ocupada por Om-at e ofereceram-se para tambem acompanha-lo na pesquisa. Era já uma demonstração de que de fato o aceitavam como chefe (ML, p. 36).

Two young warriors climbed closer to the ledge upon which Om-at stood. They were In-sad and O-dan. It was the latter who spoke.

"Gund of Kor-ul-JA," he said, "we would go with you to search for Pan-at-lee".

Em outros momentos, o tradutor se coloca no texto como um narrador onisciente. Ele não fala na primeira pessoa, mas acrescenta o pensamento de Tarzan, em forma de perguntas:

(9b) Na floresta orientou-se e tomou rumo da aldeia de OM-at. Para isso seguiu uma trilha que beirava o rio. Era certo ponto em que a correnteza chofrava a base da escarpa, teve de passar a nado para a margem oposta, visto que a trilha acabava ali. Ao pisar na margem oposta o seu faro deu-lhe aviso duma pista. A pista de Pan-at-lee! Sim, naquela margem pairava o odor da criatura que tão ardorosamente Om-at vinha procurando. Morta? Viva? Viva, talvez, pensou Tarzan, e o meio de o verificar seria seguir até o fim aquele rastro (ML, p. 48)

Below the village Tarzan returned to the foot of the cliff searching for a point where he could make the ascent to the ridge and thus back to the village of Om-at, the Kor-ul-JA. He came at last to a place where the river ran so close to the rocky wall that he was forced to swim it in search of a trail upon the opposite side and here it was that his keen nostrils detected a familiar spoor. It was the scent of Panat-lee at the spot where she had emerged from the pool and taken to the safety of the jungle. Immediately the ape-man's plans were changed. Pan-at-lee lived, or at least she had lived after the leap from the cliff's summit.

(10b) A fome era a explicação daquilo. O imenso estomago do triceratops estava a pedir carne. Tarzan tinha de solta-lo para que se alimentasse - e como fazer para o apanhar de novo? (ML, p. 68). 
[...] doubtless due to the fact that its huge belly was crying out for food. The apeman wondered if the Tor-o-dons had any means of picketing their beasts for the night, but as he did not know and as no plan suggested itself, he determined that he should have to trust to the chance of finding it again in the morning.

Novamente, a ausência de neutralidade do tradutor/narrador se evidencia por uma afirmação que insinua o sentimento de Tarzan, realçada ainda pelo ponto de exclamação:

(11b) A-lur já estava à sua frente. Que estranha arquitetura! Composta de inumeras construções escarvadas na rocha calcarea abundante ali, dava a impressão de icebergs sobre um oceano de verdura (ML, p. 70).

As Tarzan neared the city his interest became centered upon the architecture of the outlying buildings which were hewn from the chalklike limestone of what had once been a group of low hills, similar to the many grass-covered hillocks that dotted the valley in every direction.

É comum autores fazerem alusão a textos conhecidos da literatura ou da cultura de partida. Os tradutores ao reconhecerem essas referências decidem se elas são importantes, ou não, para o texto podendo substituí-las por equivalente da cultura alvo, ou se simplesmente ignorá-las. Nesse sentido, quando Burroughs, novamente nesta outra obra, lança mão da alusão poética já mencionada, com a palavra Stygian para dar ênfase à escuridão Lobato, como Bandeira, na opta por adjetivos mais literais:

(12b) Tarzan atirara-se lá de cima e envolto na mais profunda escuridão continuava a repetir o apelo: Jane. Jane, onde estás? Não obtinha resposta, mas já seu faro alertissimo sentia no ambiente o olor da companheira. Aquela impetuosa impaciência, entretanto, estragara tudo (ML, 116).

Again and again he called, Jane, Jane, groping with outstretched hands through the Stygian blackness of the room, his nostrils assailed and his brain tantalized by the delicate effluvia that had first assured him that his mate had been within this very room. And he had heard her dear voice combatting the base demands of the vile priest.

Outra referência no texto fonte, esta de cunho mais popular, remete a uma canção bastante conhecida, composta por Ben Ryan, em 1926. Entretanto, o tradutor simplesmente a omite e não busca nenhuma alusão análoga em português que estabelecesse a mesma ligação cultural:

(13b) - Jane, sou eu! disse num sussurro (ML, p. 167)

"Jane," he called, "heart of my heart, it is I". 
No trecho a seguir tanto o texto fonte quanto a tradução estabelecem uma a intertextualidade com uma obra de Alexandre Dumas. Na tradução ela é mais explícita, repetindo o bordão dos três mosqueteiros ${ }^{172}$; no texto fonte, por sua vez, é o gesto dos mosqueteiros que é replicado:

(14b) - Pois iremos então os tres juntos, propôs Tarzan.

- E juntos lutaremos, acrescentou Ta-den.

— Todos por um e um por todos! gritou Om-at. Pela vida e pela morte! (p. 21).

"We three, then, shall travel together," said Tarzan.

"And fight together," added Ta-den; "the three as one," and as he spoke he drew his knife and held it above his head.

"The three as one," repeated Om-at, drawing his weapon and duplicating Taden's act. "It is spoken!"

Já em outros momentos, quem emprega esse recurso é o tradutor. No trecho abaixo insere na tradução um verso de Victor Hugo, que não consta do original: "Souvent femme varie, bien fol est qui s'y fie" ${ }^{173}$, significando que não se deve confiar nas mulheres, pois frequentemente mudam de opinião.

(15b) - Detesta-me, estou vendo, disse ainda ele. Mas isso passa, e acabará amando-me. Femme souvent varie (ML, p. 158).

"You do not like me?" he asked. "Ah, well; it is too sad. But some day you will love me," and again the hideous laughter.

O tradutor também faz referência a um clássico da literatura infantil, que não se encontra no texto original:

(16b) Havia pelo aposento numerosas peles. Um dos guerreiros escolheu uma, a menor, e sempre na ponta dos pés aproximou-se do estrado da bela adormecida (ML, p. 179).

Upon the floor of the chamber were numerous pelts and as the leader of the trio came close to the sleeping woman he stooped and gathered up one of the smaller of these.

Para Lobato, a tradução parece estar em consonância com sua concepção de uma literatura com linguagem e temas que fossem brasileiros. Assim, além da mudança de perspectiva narrativa, a tradução promove uma "atualização" do texto. Nesta primeira

\footnotetext{
${ }^{172} \mathrm{Na}$ tradução em inglês que consta do Projeto Guttenberg: "All for one and one for all, united we stand divided we fall".

${ }^{173}$ Marie Tudor, III, ato I, cena 2.
} 
passagem o texto fonte é marcado por uma referência ao contexto estrangeiro, que no período ainda não sofria a influência de costumes americanos como nos dias de hoje. Lobato que desde sua primeira publicação prezava o ambiente rural, aproxima o texto da realidade do país:

(17b) Pan-at-lee encaminhou- se para a sua aldeia com a simplicidade e despreocupação duma lavradora que se dirige para a roça (ML, p. 64).

She moved therefore through her savage land with no greater show of concern than might mark your sauntering to a corner drug-store for a sundae.

Contudo, neste outro exemplo, o tradutor opta pelo nome da capital inglesa, talvez, para relembrar o leitor da origem civilizada do herói:

(18b) Com a mesma segurança com que andaria pelas ruas de Londres, Tarzan tomou pela via principal de A-lur (ML, p. 71).

With the same assurance that you might venture upon the main street of a neighboring city Tarzan strode into the Ho-don city of A-lur.

Lobato preconizava um uso de uma linguagem mais coloquial aproximando o texto do leitor. Orientado por esse princípio, o tradutor recorre a algumas estratégias. Uma delas é a inserção de expressões idiomáticas:

(19b) - Alto! exclamou Tarzan. Mexer em religião é mexer em ninho de vespa. Falemos de assuntos menos excitante do que politica e religião (ML, p. 24).

"Enough!" he snapped. "Let us be true to our oaths of friendship that we may be honorable in the sight of God in whatever form we conceive Him".

Ele também opta por vocábulos do português do Brasil ${ }^{174}$, seguindo sua convicção da necessidade de linguagem simples e mais brasileira, que diferisse das publicações portuguesas:

(20b) - Mas quem é afinal de contas o meu acusador e juiz? disse Tarzan pondo de lado a pendenga (ML, p. 92).

"But who," said Tarzan, "is my accuser and who is my judge?"

Abaixo, acha-se outro exemplo de palavras, que apesar de etimologicamente datarem do século 16, é dicionarizada no começo do século como sendo de cunho popular.

${ }^{174}$ Segundo Dicionário Caldas Aulete, 1926. 
(21b) Grata á lança que lhe permitiu semelhante regabofe, amimou-a carinhosamente.

Never, thought Lady Greystoke, had aught more delicious passed her lips. She patted her spear affectionately.

Com frequência, o tradutor lança mão de sinônimos menos eruditos. Observa-se abaixo que thin lips remete à maldade, "beiço" sugere lábios fartos e, numa concepção lambrosiana, está bastante associado à expressão de glutonia e lascívia.

(22b) Lu-don correu a lingua pelos beiços (ML. p. 181).

Lu-don, the high priest, licked his thin lips.

Outros recursos além da palavra revelam, também, a presença do tradutor no seu texto. É o que se verifica nos trechos a seguir. As aspas na ocorrência abaixo têm um uso ideológico, ressaltando uma condição:

(23b) - É a minha cidade, respondeu o pitecantropo glabro, não a de Om-at. Os Waz-dons não têm cidades; vivem nas árvores das florestas e nas cavernas das montanhas - não é verdade "homem negro"? concluiu voltando-se para o gigante peludo (ML, p. 20)

"It is mine," replied the hairless one; "but not Om-at's. The Waz-don have no cities - they live in the trees of the forests and the caves of the hills-is it not so, black man?" he concluded, turning toward the hairy giant beside him.

Tanto em inglês quanto em português, a escolha da fonte em itálico confere destaque. Na história dois povos falam línguas distintas, inventadas por Burroughs, mas que se limitam no texto à referência da inteligência de Tarzan de aprendê-las rapidamente e bem como alguns termos e nomes próprios. Lobato utilizou o itálico somente me um desses vocábulos em vez de utilizar aspas, para evidenciar o caráter estrangeiro, que em inglês não é ressaltado:

(24b) - Bem, disse Om-at, sou eu agora o gund. Todos me devem obediencia (ML, p 34).

"Then Om-at is gund," he said with finality.

(25b) - Trouxemo-lo vivo gund, dizia um deles, porque nunca vimos Ho-don deste tipo (ML, p. 46).

"We brought him to you alive, Gund," he heard one of them saying, "because never before was Ho-don like him seen. 
A informação entre parênteses é uma intervenção flagrante do tradutor, que põe em evidencia uma informação ou porque lhe pareça digna de nota, ou porque o texto foi muito condensado. Neste primeiro caso a explicação entre parênteses é desnecessária, pois durante a cena já havia sido explicitada a condição dos dois jovens.

(26b) - Bem, disse Om-at. Ta-den, In-sad (um dos jovens guerreiros) e eu tomaremos a frente; depois virá Tarzan; O-dan (o outro jovem guerreiro) nos seguirá na retaguarda, retirando os espeques. Não podemos deixa-los nos furos por causa dos nossos inimigos.

"All right," agreed Om-at; "Ta-den, In-sad, and I will go first, you follow and $O$ dan bring up the rear and collect the pegs-we cannot leave them here for our enemies".

Nos dois trechos seguintes observa-se a tradução resumida do trecho, destacando com parênteses parte da informação.

(27b) Julgaram a principio que fossem vedetas de alguma força enviada por Ludon; mas criaturas incapazes do desempenho de qualquer função guerreira (Os homens de armas de Pal-ul-don secretamente desprezavam os sacerdotes emasculados) (ML, p. 145).

As the three canoes reached the portage on their return journey the warriors who were dragging them from the water were suddenly startled by the appearance of two priests, carrying a light canoe in the direction of Jad-in-lul. At first they thought them the advance guard of a larger force of Lu-don's followers, although the correctness of such a theory was belied by their knowledge that priests never accepted the risks or perils of a warrior's vocation, nor even fought until driven into a corner and forced to do so. Secretly the warriors of Pal-ul-don held the emasculated priesthood in contempt and so instead of immediately taking up the offensive as they would have had the two men been warriors from A-lur instead of priests, they waited to question them.

(28b) Mas Tarzan, sorrindo, tomou a preciosa lança de silex fabricada por sua companheira (que carinhosamente ele levava como um trofeu) e avançou para o triceratops com os gritos de domesticação dos Tor-odons na bôca (ML, p. 192).

He still carried the spear that Jane had made, which he had prized so highly because it was her handiwork that he had caused a search to be made for it through the temple in A-lur after his release, and it had been found and brought to him. He had told her laughingly that it should have the place of honor above their hearth as the ancient flintlock of her Puritan grandsire had held a similar place of honor above the fireplace of Professor Porter, her father.

Nesta passagem, o tradutor explicita o que está implícito no texto fonte:

(29b) Em seguida á fatura da lança Lady Clayton metue-se á tarefa de enriquecer o seu arsenal. [...] O corte de paus da necessaria grossura para a construção do 
abrigo (feito com o machado de silex tambem por ela afeiçoado) consumia-lhe horas e horas de trabalho duro (ML, p. 154).

She felt that she must have, in addition to a good spear, a knife, and bow and arrows. [...] The cutting of the long poles for her home occupied all of the daylight hours that were not engaged in the search for food.

A evidente interferência em favor do leitor pode revelar que o tradutor desconsidera sua capacidade de inferência, como no exemplo abaixo:

(30b) Quando o sol se ergueu (pois tudo aquilo ocorrera ainda pela madrugada), as forças de Ja-don ainda se mantinham firmes (ML, p. 183).

The sun rose to see the forces of Ja-don still held at the palace gate.

A pontuação também é significativa na medida em que sugere uma emoção ou estado de espírito, além de ter seu valor ligado à sintaxe. As reticências nestas passagens a seguir sugerem a suspensão do fluxo de pensamento no esforço de sugerir a busca pela memória, como no primeiro exemplo, ou sugerir resignação, como no segundo:

(31b) Pôs-se a refletir. Aquele guerreiro... Ele o conhecia. Já o vira. Mas onde? Quando? Subito recordou-se (ML, p. 184).

He wondered how they had stolen her from Ja-lur, and then suddenly there flashed to his mind the features of the warrior whom he had just seen with her. They were strangely familiar. He racked his brain to recall where he had seen the man before and then it came to him.

(32b) Nisto ouviu a barulheira dos gongos. "Já deram o alarma, pensou. O combate está travado - e eu, o comandante daqueles homens, aqui..." (ML, p. 184).

Presently he heard the clanging of a gong from the corridor without and very faintly the rush of feet, and shouts. He guessed that his warriors had been discovered and a fight was in progress. He fretted and chafed at the chance that had denied him participation in it.

Os tipos de ocorrência na tradução de Lobato apontam para intervenções oriundas de sua maneira particular de recontar a história com suas palavras. Consequentemente, o texto alvo, além de sofrer cortes, recebe acréscimos. No trecho abaixo, o contexto já estabelece que o objeto da observação é um leão, mas o tradutor reforça a menção com uma expressão coloquial:

(33) - Tivesse eu um irmão e não o conheceria melhor do que a estes gatos de juba (ML, p 39).

"Had I a brother I could not know him better," replied Tarzan. 
Nesta passagem a exclamação da personagem sugere a intensidade do alívio ausente no texto fonte:

(34b) - Começo a respirar! exclamou Jane aliviada. Ganho tempo, ganho tempo (ML, p. 123).

"Delay!" she murmured; "blessed delay!"

Um outro aspecto do pensamento de Lobato era o de enriquecer a cultura nacional pelo contato com culturas estrangeiras, principalmente a americana. Ainda que não visasse uma renovação linguística, algumas ocorrências de palavras estrangeiras ainda não dicionarizadas à época, mas já de uso corrente, aparecem nas traduções:

(35b) Engalfinhados que estavam, cairam ambos. Tarzan, porém, cuja mobilidade era assombrosa, soube girar sobre si antes de chegar ao chão, de tanto lhe custou um handicap; a faca escapou-lhe dos dedos saltando longe (ML, p. 51).

The two fell heavily, but so agile was the ape-man and so quick his powerful muscles that even in falling he twisted the beast beneath him, so that Tarzan fell on top and now the tail that had tripped him sought his throat as had the tail of Intan, the Kor-ul-lul. In the effort of turning his antagonist's body during the fall Tarzan had had to relinquish his knife that he might seize the shaggy body with both hands and now the weapon lay out of reach at the very edge of the recess.

\subsection{4. c) Tarzan, o rei da jângal, tradução de Godofredo Rangel}

Das três obras do corpus, a tradução de Godofredo Rangel é a que mais segue a estrutura narrativa, a cronologia dos acontecimentos e a que apresenta maior correspondência nos diálogos. Até mesmo a linguagem figurada com alusão à mitologia é traduzida literalmente por Rangel, mesmo que soe estranha para o público alvo.

Na passagem a seguir, a expressão em questão remete à Ciméria, região ao norte do mar Negro, cujo povo invadiu a Ásia Menor no século 7 A.C.; todavia, o seu sentido figurado é relativo a um país imaginário frio e enevoado que, segundo Homero, se situava perto da morada dos mortos. O tradutor mantém a referência, que não é comum na cultura alvo, mas ao utilizar "sombra" enfatiza o aspecto do túnel escuro e perde o jogo que ao desconhecimento por parte do resto do mundo da cidade medieval em meio a selva africana, sugerida pela palavra oblivion:

(1c) Nem seu proprio mysterio impressionador dissipava a monotonnia das paredes immutaveis que por breve instante surgiam silenciosas á luz frouxa do archote e silenciosas remergulhavam, para traz, na sombra cimmeria, para serem substituidas por outros trechos de paredes invariavelmente iguaes (GR, p. 69). 
Even the haunting mystery of the long tunnel failed to overcome the monotony of its unchanging walls that slipped silently into the torch's dim ken for a brief instant and as silently back into the Cimmerian oblivion behind to make place for more wall unvaryingly identical.

Especificamente nesta obra do corpus, Burroughs procura ressaltar linguisticamente as consequências desse isolamento em que os cavaleiros medievais se encontram há séculos, lançando mão de formas arcaicas do inglês, todavia, o tradutor adota sempre o português padrão, apagando as marcas deixadas pelo autor:

(2c) - Não deixe seu escudo impedir que você veja a espada delle, James aconselhou Richard. - Tenha sempre o olhar nos olhos delle, para saber onde elle vae golpear e em seguida intercepte o golpe com o escudo, pois sir Malud é lento no ataque e sempre seu olhar annuncia onde a lamina vae ferir. Conheço-o perfeitamente, pois temos combatido muitas vezes (GR, p. 103).

"Hide not his sword from thine eyes with thy buckler, James," cautioned Richard. "Ever keep thine eyes upon his eyes until thou knowest whereat he striketh, then, with thy buckler ready, thou mayst intercept the blow, for he be over-slow and always his eyes proclaim where his blade will fall. Full well I know that, for often have I exercised against him".

(3c) Sir Richard olhou-o e sorriu.

— Está sempre a galhofar, mesmo em face da morte - disse. — Parecem-se a você todos os homens de seu extranho paiz? (GR, p. 103).

Sir Richard looked up and smiled. "Thou wilt always joke, even in the face of death," he said. "Are all the men of this strange country thou tellest of alike?"

(4c) - Eram exercícios apenas e o caso amanhan é differente, pois Malud desejará que seja uma lucta de morte, para lavar com sangue o ultraje que recebeu (GR, p. 104).

"Ah, we did but practice, but on the morrow it will be different, for Malud engages thee to the death, in mortal combat my friend, to wash away in blood the affront thou didst put him".

Outro recurso do autor para marcar a diacronia entre os falares são as expressões idiomáticas, os coloquialismos de cada época e cultura americana e anglo-saxônica. Nos diálogos abaixo o americano e o cavaleiro estão fazendo um brinde e o desentendimento dá um toque de humor, que leva o tradutor a buscar uma linguagem bastante informal. O sentido figurado de "quebrar a munheca" é o de beber muito, embriagar-se; a interjeição $O d$ é um eufemismo para God e normalmente vem associada a blood e body, cujo arcaísmo não é reproduzido na tradução que é mais neutra.

(5c) - Tambem "quebro a munheca" em sua saude - respondeu Blake. 
- Curiosa saudação! - observou sir Richard - Calculo, todavia, que os costumes inglezes devem ter mudado muito desde os tempos de Ricardo Coração de Leão, quando meus nobres antepassados partiram para a grande cruzada, em companhia do rei. "Quebro a munheca"! É estupendo! (GR, p. 76).

"Here's looking at you!" replied Blake.

"A quaint saying," remarked Sir Richard. "Methinks the ways of England must be changed since the days of Richard the Lion Hearted when my noble ancestor set forth upon the great crusade in the company of his king. Here's looking at you! 'Ods bodikins!

- É incrivel! Talvez tenha razão, sir Malud! - prorompeu (sic) o principe. Nenhum inimigo? Seria possivel que os cavalleiros de Nimmr aqui residissem sete seculos e meio sem que alguma horda de infieis cercasse o seu reducto? (GR, p. $80)$.

"Ods blood! Methinks thou art right, Sir Malud," cried the prince. "No enemy indeed! Why else then have the knights of Nimmr lain here seven and a half centuries if there be no horde of infidels surrounding our stronghold?"

Abaixo, também, o coloquialismo de old scout é mais atenuado na tradução:

(6c) -Você é uma perola, Richard! - disse, pousando affectuosamente a mão no hombro do amigo (GR, p. 104).

"You're a good old scout, Richard," he said, placing a hand affectionately upon the other's shoulder.

Na continuação da conversa, o americano confessa não poder responder à pergunta do príncipe com o coloquial search me (eu não sei!), sentido totalmente diferente daquele entendido pelo tradutor. Às vezes, o tradutor parece compensar o fato de não diferenciar o modo de falar entre os dois utilizando expressões e termos muito mais informais do que os do texto fonte, como nos dois exemplos abaixo:

(6c) - Isso chega a ser "gozado"! - comentou Blake.

"Search me," said Blake.

(7c) - Raios me partam se não quero! (GR, p. 80).

"I'll tell the world I would!" he said.

Nesta outra passagem, a tradução tem um sentido diferente do original:

- Entendo bastante o seu falar exotico para apprehender-lhe a significação, Blake, mas garanto-lhe que você não me illude. O olhar da princeza raro se aparta dos seus, por occasião dos exercicios de manejos de armas; e, quanto aos seus, ao fixal-a... - Já reparou o olhar de um cão a adorar o seu dono?

- Ora deixe-se de lérias! — disse Blake (GR, p. 104). 
"Enough of thy outlandish speech I grasp to gather thy meaning, James, but thou canst not confuse me upon the one subject nor deceive me upon the other. The eyes of the princess seldom leave thee whilst thou art at practice upon the lists and the look in thine when they rest upon her-hast ever seen a hound adoring his master?"

"Run along and sell your papers," admonished Blake.

Neste diálogo de Blake com o príncipe Gobred a informalidade do americano é acentuada pelo exagero de coloquialismos e expressões idiomáticas do americano (GR p. 128), resultando numa cena improvável, uma vez que na realidade o americano não mostraria tanto desrespeito pela investidura do cargo.

(9c) - Se não o fossem, elles veriam o russo - explicou Blake.

- "Veriam o russo"! - repetiu o principe. - Isso é alguma especie de castigo?

- Vossa alteza o disse, principe!

- Naturalmente que eu o disse! retrucou, severo, Gobred.

"If they're not they get the raspberry," explained Blake.

"'Get the raspberry'!" repeated Gobred. "'Tis some form of punishment, methinks."

"You said it, Prince!"

"Of a surety I said it, Sir James!" snapped Gobred with asperity.

Nesta passagem, Rangel, primeiramente, faz uma tradução literal da expressão to hit the nail on the head, desnecessária, uma vez que lança mão de um equivalente do ditado em português:

(10c) - O que eu quiz dizer, principe, é que vossa alteza bateu na cabeça do prego, isto é, deu no vinte, ou melhor, que adivinhou de prompto. "Ver o russo" é o unico castigo admissivel em casos taes, para os cavalleiros do Circo Quadrado ou para os cavalleiros do Diamante.

"I mean, Prince, that you hit the nail on the head-you guessed it the first time. You see the raspberry is about the only form of punishment that the Knights of the Squared Circle, or the Knights of the Diamond can understand."

Na ocorrência abaixo o vocábulo inglês dotty, para excêntrico ou meio louco, é mais informal que "desbriados", ou seja, "sem brio".

(12c) - Alguns são meio desbriados, mas uma boa penca dos mesmos são valentes. Sir Dempsey, por exemplo, é um nobre cavalleiro do Circo Quadrado 
"Some of them are dotty, but a lot of them are regulars. Take Sir Dempsey, for instance, a knight of the Squared Circle.

O termo "piolheira", conforme dicionarizado em 1925, significa porcaria, conjunto de coisas miseráveis e se aproxima do sentido em inglês, sendo que louse é piolho e to be lousy na linguagem informal refere-se a lugar infestado de pessoas indesejadas:

(13c) - Existem actualmente outras ordens de cavallaria?

- Temos uma piolheira dellas!

- Como? - gritou Gobred.

- Todos são cavalleiros actualmente - explicou Blake.

"Be there other orders of knighthood these days?" demanded Gobred.

"We're lousy with them!"

"What!" cried Gobred.

"We're all knights these days," explained Blake.

Interessante observar como o tradutor transfere o trocadilho, utilizando palavras homófonas, para o termo "servo", que em inglês se encontra nas diferentes acepções de yeoman: a de homem-livre proprietário de terra e a de homem do mar.

(14c) - Cavalleiros ! Então não existem servos? E’ phantastico!

— Cervos? Sim, mas só em logares sylvestres e jardins zoologicos. Praticamente pode-se dizer que todos somos cavalleiros.

"All knights! Be there no serfs nor yeomen? 'Tis incredible!"

"Well, there are some yeomen in the navy, I think; but all the rest of us, pretty much, are knights".

Conforme já mencionado neste capítulo, Burroughs, em Lord of the jungle, utiliza estrangeirismos que remetem à cultura árabe, mas que às vezes são omitidos na tradução, outras vezes substituídos por correspondentes do vernáculo menos expressivos e, se reproduzidos, aparecem entre aspas. A tradução de palavras estrangeiras não segue nenhum padrão. Nesta passagem o termo bwana, de origem africana, é transposto para o texto alvo, sem nenhuma marca ou mudança na ortografia. Observe-se que o termo foi encontrado em dicionários da época. 
(15c) O preto aproximou-se e estacou ante os dois brancos.

— O senhor me chamou, Bwana? - perguntou.

- Reuna a todos os homens - ordenou Stimbol - e traga-os aqui dentro em cinco minutos, para nos entendermos com elles - traga-os todos, até o ultimo.

— Sim, Bwana (GR, p. 41).

The black approached and stopped before the two white men. "You called me, Bwana?" he asked.

"Gather up every one in camp," directed Stimbol. "Have them up here in five minutes for a palaver - every last man-jack of them."

"Yes, Bwana".

(16c) - Então os homens resolveram quaes são os que vão acompanhar o senhor Stimbol? - perguntou elle.

- Nenhum quer acompanhar o velho Bwana - respondeu o intermediário. Todos desejam ir com o Bwana moço (GR, p. 45).

"Well, have the men decided who will accompany Mr. Stimbol?" he asked.

"No one will accompany the old bwana," replied their spokesman. "All will go with the young bwana".

Além dessas palavras evocativas, o autor recorre à mesma forma arcaica usada nas falas dos cavaleiros para caracterizar uma fala distinta. Essa fala marcada não ocorre em Tarzan and the jewels of Opar, em cuja história os antagonistas são também os árabes, mas em Tarzan, lord of the jungle é bem marcada:

$(17 \mathrm{c})$ - Para onde vae? para a sua terra?

- Sim, para el-Guard (p. 82).

"Whither goest thou—to thine own country?"

"Yes, to Beled el-Guad, a Beny Salem fendy of el-Harb".

(18c) Ibn Jad, de carranca fechada, ficou sentado a reflectir, mas dahi a instantes voltou-se para Tarzan com um sorriso. Concebera uma idéa astuciosa.

- Sem duvida o pobre Zeyd suppunha estar a dizer a verdade, e o motivo de o suppor era o mesmo que o levou a querer matar seu sheik. Quero dizer que sempre teve o cerebro fraco, mas eu nunca julguei que fosse um louco perigoso. Elle o enganou, Tarzan dos Macacos, e isto eu posso provar com todos os meus companheiros, assim como com o christão que aqui se acha; todos lhe dirão que procurei obedecer a suas ordens e sahir de seus territorios. Que outra cousa fiz senão viajar pelo norte, de volta para a minha terra? 
- Se pretendia obedecer-me porque me conservou prisioneiro e mandou seu irmão matar-me á noite? - perguntou Tarzan.

— Está novamente a julgar-me mal — disse Ibn Jad em tom sentido. — Meu irmão foi cortar as cordas que o prendiam e soltal-o, mas o senhor atirou-se sobre elle. Depois veio o elephante e levou-o comsigo.

- Nesse caso, porque seu irmão levantou a faca e gritou: Morra, christão? perguntou o homem-macaco. - Quando um homem assim fala está a mostrar bondade?

— Eu apenas gracejava — murmurou Tollog.

Ibn Jad sat in thought, his brows contracted in a dark scowl, but presently he looked up at Tarzan with a crooked smile. "Doubtless the poor youth thought that he spoke the truth," he said. "Just as he thought that he should slay his sheikh and for the same reason. Always hath his brain been sick, but never before did I think him dangerous.

"He hath deceived thee, Tarzan of the Apes, and that I can prove by all my people as well as by this Nasrany I have befriended, for all will tell thee that I am seeking to obey thee and leave thy country. Why else then should I have traveled north back in the direction of my own beled?"

"If thou wishedst to obey me why didst thou hold me prisoner and send thy brother to slay me in the night?" asked Tarzan.

"Again thou wrongst Ibn Jad," said the sheikh sadly. "My brother came to cut thy bonds and set thee free, but thou settest upon him and then came el-fil and carried thee away."

"And what meant thy brother when he raised his knife and cried: 'Die, Nasrany!" demanded the ape-man. "Sayeth a man thus who cometh to do a kindness?"

"I did but joke," mumbled Tollog.

Já foi comentado o uso de artifícios ortográficos na tradução de Rangel de aspas e da fonte em itálico para evidenciar o caráter estrangeiro de uma palavra. Também as reticências apontam para uma interpretação do tradutor. No diálogo essa pontuação ajuda a reconstruir a hesitação da personagem reforçada pelo verbo "gaguejar":

$(19 \mathrm{c})$ - Oh!... Sim... Mas... . E’ você? — gaguejou Stimbol.

"Who the-oh, it's you is it?" exclaimed Stimbol. "Here's the wild man, Blake".

Nesta conversação, por sua vez, as reticências realçam o corte da frase do americano pela interferência de Tarzan. A rudeza demonstrada com relação a um dos homens é acentuado pelo tratamento formal de "senhor", ausente no texto fonte:

(20c) - E quaes os seus planos, para depois da separação? 
- Pretendo internar-me um pouco mais para o oeste e em seguida dar uma volta por... - começou Stimbol.

- Estou-me dirigindo ao senhor Blake - interrompeu-o Tarzan. — Quanto ao senhor, já firmei minha resolução.

— E qual é ella, com mil...

— Cale-se! - advertiu o homem-macaco. - Continue, sr. Blake (Gr, p. 45).

"And after you separate—what are your plans?"

"I intend to push in a little farther west and then swing_- commenced Stimbol.

"I was speaking to Blake," interrupted Tarzan; "my plans concerning you are already made".

"Well, who the-"

"Silence!" admonished the ape-man. "Go ahead, Blake!"

Dentre os sinais gráficos que se observam nos textos alvos, o que mais denota a presença do tradutor talvez seja o parênteses, exatamente por incluir uma explicação, uma reflexão, um comentário marginal ou uma informação extra em benefício do leitor. Nos excertos abaixo esse recurso é utilizado por Rangel, mas, a julgar pelo contexto, parecem dispensáveis. A ocorrência abaixo já foi comentada anteriormente e mostra a redundância de realce, pois o tradutor além de usar aspas explica o termo em parênteses:

(21b) Na floresta, os beduinos Fahd e Motlog caçavam ao norte do «menzil» (acampamento) do sheik Ibn Jad, de el-Guad, em Beni Salem (GR, p. 8).

In the forest Fahd and Motlog, of the tribe el-Harb, hunted north from the menzil of Sheikh Ibn Jad of the Beny Salem fendy el-Guad.

No trecho a seguir, apesar de termos como mandioca como macaxeira, aipim serem mais corriqueiros, o vocábulo "cassava" já era vernáculo e encontrava-se dicionarizado em 1925, com esta mesma grafia ${ }^{175}$, parecendo desnecessária a explicação:

(22c) Mataram uma cabra e muitos frangos, e em abundancia para todos houve fructas, pão de cassava (especie de mandioca) e uma bebida fermentada fabricada pelos nativos. Tambem houve dança e musicas.

A goat was killed and many chickens, and there were fruit and cassava bread and native beer in plenty for all. There was music, too, and dancing.

${ }^{175}$ Variação do haitiano Cazabi. http://www.aulete.com.br 


\section{CONCLUSÃO}

This is the hour of pride and power Talon and tush and claw

Oh, hear the call - Good hunting all That keep the jungle law!

The Jungle Book, Rudyard Kipling

O levantamento das obras em prosa traduzidas na década de 1930 revelou um panorama instigante de literatura de entretenimento - ficção científica, romances de aventura, romances "água-com-açúcar", histórias policiais e livros de autoajuda - e de outras línguas além do francês. Tratava-se de um momento de grandes mudanças sociais e políticas em que um público consumidor de cultura de massa começava a se formar. Surpreendeu, ainda, os nomes dos tradutores que se dedicaram a traduzir essas obras, em sua grande maioria, ligados ao meio literário e consagrados escritores e poetas.

Esses livros, apesar de não apresentarem valor estético, segundo os conceitos da crítica literária, são obras representativas de um momento histórico e foram importantes para a formação de um público leitor e, por isso, merecedoras de atenção. Destarte, partindo da hipótese de que na tradução as condições de recepção e o momento histórico são fatores importantes no resultado do livro traduzido, e de que o gênero literário impõe condicionantes que tendem a limitar o caráter autoral e criativo da atividade, a investigação foi realizada trilhando o caminho apontado pela história cultural.

Nos primeiros capítulos, verificou-se a importância do momento histórico e das consequências das ações do governo de Getúlio Vargas no campo editorial e no desenvolvimento da indústria livreira, que fomentou a tradução literária e observou-se a atuação dos tradutores nesse contexto. A seguir, à luz da virada cultural dos estudos da tradução foram discutidas as teorias que embasam o estudo, principalmente as de Even- 
Zohar e Gideon Toury, contudo, sem descartar as discussões de como o tradutor marca sua presença no texto e de como ele negocia as condicionantes importas pelo gênero.

Ao final desse percurso, constatou-se primeiramente que a nova perspectiva mercadológica que se instaurou no período influenciou a escolha dos títulos a serem traduzidos, visando uma novo público consumidor de cultura de massa. Em um ambiente dominado por uma elite intelectual, a indústria livreira foi buscar entre escritores e poetas os tradutores para essas novas publicações. Também, observou-se a preferência de textos em inglês sobre os em francês, que dominavam as traduções nos anos anteriores. Dentre as obras publicadas, as histórias de Tarzan gozavam de grande sucesso no Brasil e o herói, submetido a um processo de iconização pelo cinema, já fazia parte do repertório imagético do leitor.

Como o trabalho parte do âmbito geral, o contexto, e vai se estreitando gradativamente até o específico, ele foi finalizado com as análises das traduções de três livros da série Tarzan, ainda sem perder de vista a relação entre os tradutores e o seu meio e seu tempo.

A análise dos paratextos evidenciou a forte mediação editorial estabelecendo parâmetros de uniformização do aspecto material do livro conferindo-lhe identidade visual e conteudística, uma vez que o corpus faz parte de uma coleção. A padronização dos livros da coleção também ocorre com relação à temática, em consonância com o público a que ela se dirige, o jovem.

Os três livros do corpus - O tesouro de Tarzan, Tarzan o terrível e Tarzan o rei da jângal - sofrem uma redução textual, criando-se homogeneidade nas dimensões dos volumes. Todavia, notou-se que os textos fontes são muito mais longos que os textos alvos e que a manipulação da estrutura textual é de maior monta na tradução de Lobato, que conta com um número de palavras muito inferior aos da tradução dos outros dois títulos. Concluiu-se que além das exigências editoriais outro fator pode ter contribuído para esse corte drástico: a ideia do famoso autor e editor de deixar a leitura mais fluente. Um ponto em comum entre as traduções de Bandeira, Lobato e Rangel é a omissão do "aparato descritivo", ou por não considerarem essencial para o entendimento da história ou por terem em mente o leitor menos competente, para quem o importante é ação.

A ambientação das histórias de Tarzan gera um campo semântico específico, com algumas palavras-chaves analisadas. Em um primeiro momento, a análise desses termos presentes nos três livros revelou uma necessidade de ampliação do léxico 
evitando repetições. A busca de sinônimos pode ser determinada pelo fato de que, diferentemente do inglês, o português estilisticamente não aceita tantas repetições de palavra, a não ser em casos específicos, daí a necessidade de se buscarem equivalentes de sentido parecido.

Além da selva africana, as três narrativas transcorrem em lugares diferentes, e para fins de ambientação, Burroughs recorre não só a um léxico específico, como marca as falas de alguns personagens. Em duas histórias os árabes são os antagonistas, mas somente em uma a diferença a linguagem dos árabes é marcada pela diacronia e a cultura por estrangeirismos. Também, nessa mesma narrativa, cavaleiros medievais falam inglês arcaico. Contudo, os diferentes falares são apagados na tradução, de Rangel, e somente alguns termos evocativos são mantidos,

Observou-se que as escolhas também são ideacionais e podem ser motivadas pela sensibilidade e pelo conhecimento linguístico do tradutor. O grande número de falsos cognatos na tradução de Bandeira aponta para uma competência no seu inglês inferior às de Lobato e Rangel.

Durante a análise notou-se que os tradutores se "insinuam" no texto por meio de aspas, parênteses e acréscimos. Além disso, eles promovem uma atualização da linguagem ao adotarem coloquialismos, gírias e expressões idiomáticas da época. Ao final da análise das três obras, observou-se que a tradução é resultante de várias instâncias e observou-se o impacto do gênero e do contexto na presença discursiva do tradutor. A análise da tradução de três livros da série Tarzan revelou a preocupação com o projeto editorial das coleções e com o seu público leitor. 


\section{BIBLIOGRAFIA}

\section{OBRAS DO CORPUS}

BURROUGHS, Edgar Rice. O tesouro de Tarzan (Trad. Manuel Bandeira). São Paulo: Companhia Editora Nacional, 1949.

. Tarzan and the jewels of Opar. Project Gutenberg Etext

http://www.cs.cmu.edu/ rgs/tar5-table.html. Acesso 15/08/2012.

Tarzan, o invencível (Trad. Monteiro Lobato). São Paulo:

Companhia Editora Nacional, 1935.

. Tarzan, the invincible. Project Gutenberg Etext

http://www.cs.cmu.edu/ rgs/tar5-table.html. Acesso 15/08/2012.

. Tarzan, o rei da jângal (Trad. Godofredo Rangel). São Paulo:

Companhia Editora Nacional, 1935.

. Tarzan, lord of the jungle. Project Gutenberg Etext.

http://gutenberg.net.au/ebooks06/0600681h.html Acesso 05/05/2014.

\section{REFERÊNCIAS BILBIOGRÁFICAS}

ABREU, Anna Lúcia Segadas Vianna. Pollyanna: domesticação e estrangeirização na tradução de Monteiro Lobato. Cadernos do CNLF, Vol. XIV, No 2, t. 2. p. 1543-1554. Disponível em: http://www.filologia.org.br/xiv_cnlf/tomo_2/1543-1554.pdf. Acesso em 02/04/2014.

ADAMO, Sergia. "Microhistory of translation". In: BASTIN, George \& BANDIA, Paul. Charting the future of translation history. Ottawa: University of Ottawa Press, 2006.

AMORIM, Lauro M. "Os lugares discursivos do tradutor e do adaptador e os meandros da visibilidade”. Tradução em Revista 2, 2005 pp. 19-35. 
ANDRADE, Carlos Drummond. Poemas ingleses de Guerra. In: SIMON, Iumna Maria (Org.). Território da tradução. Remate de males. n. 4. Revista do Departamento de Teoria Literária. IEL - UNICAMP/FUNCAMP. Campinas: 1984.

. Godofredo Rangel: um delicado. Obras Completas. Rio de Janeiro:

Companhia Aguilar, 1964. P. 713-716.

ANDRADE, Mário de. Tradutores Poetas. In: SIMON, Iumna Maria (Org.). Território da tradução. Remate de males. n. 4. Revista do Departamento de Teoria Literária. IEL UNICAMP/FUNCAMP. Campinas: 1984. . Vida literária. São Paulo: Edusp, 1993.

; BANDEIRA, Manuel. Itinerários: cartas a Alphonsus de Guimarães Filho. São Paulo: Livraria Duas Cidades, 1974.

AROSA, Dayse Mary Ventura. Anos de nacionalismo: a língua e a tradução dos anos 1930/1940. In: Tradução em Revista 5, Rio de Janeiro: Puc-Rio, 2008.

Disponível em: http://www.maxwell.lambda.ele.puc-rio.br

Acesso 12/02/2014.

ARROYO, Leonardo. Literatura infantil brasileira. São Paulo: Melhoramentos, 1990.

ATHANÁZIO, Enéas. O amigo escrito. Florianópolis: Secretaria de Estado da Cultura e do Esporte / Secretaria de estado da Casa Civil, 1988.

. Godofredo Rangel. Curitiba: Gráfica Editora 73, 1977.

Minarete, 2002.

. As antecipações de Lobato e outros escritos. Santa Catarina:

AZENHA Jr, João. A tradução para a criança e para o jovem: a prática como base da reflexão e da relação profissional. Pandemomium germanicum. Revista de estudos germanísticos. V. 9. Departamento de Letras Modernas - FFLCH/USP. São Paulo, 2005. pp. 367-392.

. Dependências, assimetrias e desafios na tradução para a criança e o jovem no Brasil. Vozes Olhares Silêncios: diálogos transdisciplinares entre a linguística aplicada e a tradução. Universidade Federal da Bahia. Salvado, 2008. pp. 97-114.

BACIU, Stefan. Manuel Bandeira de corpo inteiro. Rio de Janeiro: José Olympio, 1966.

BAKER. Mona. Towards a methodolgy for investigating the style of literary translators. Target. 12:2. pp 241-266. John Benjamins, 2000. . In other words. London \& New York: Routledge, 1992. 
BANDEIRA, Manuel. Itinerário de Pasárgada. 3 ed. São Paulo: Editora do Autor, 1966.

Editora Nacional, 1946.

. Noções de história das literaturas. vol II. São Paulo: Companhia . Crônicas inéditas. vol 2. São Paulo: Cosac Naif, 2009.

BASSNETT, Susan; LEFEVERE, André. Constructing cultures: essays on literary translation. Clevedon, Buffalo, Toronto, Sydney: Multilingual Matters, 1998. . Translation, history and culture. London: Pinter, 1990.

BLOOM, Harold. The western canon. New York: Riverhead Books, 1995.

BOSI, Alfredo. História concisa da literatura brasileira. 46 ed. São Paulo: Cultrix, 2002.

BRAIT, Beth. Estilo. In: (Org.) Bakhtin, conceitos-chave. São Paulo: Contexto, 2005. . A personagem. 7 ed. São Paulo: Ática, 2000.

BURROUGHS, Edgar Rice . Tarzan, o filho das selvas. (Trad. Thiago Lins). São Paulo: Zahar, 2014.

CAMPOS, Giovana Cordeiro; OLIVEIRA, Maria Clara Castellões. O pensamento e a prática de Monteiro Lobato como tradutor. Ipotesi, Juiz de Fora, v. 13, n. 1, p. 67 - 79, jan./jul. 2009. http://www.revistaipotesi.ufjf.br/ipotes21.html Acesso 21/03/2014.

CANDIDO, Antonio. Literatura caligráfica. In: RANGEL, GODOFREDO. Falange gloriosa. São Paulo: Melhoramentos, 1955.

.CASTELLO, José Aderaldo. Modernismo: história e antologia. 15 ed. Rio de Janeiro: Bertrand Brasil, 2006.

CARNEIRO, Maria Luiza Tucci. Livros proibidos, idéias malditas. 2 ed. São Paulo: Atleliê Editorial, 2002.

CASSAL, Sueli Tomazini Barros. Amigos escritos. São Paulo: Imprensa Oficial do Estado, 2002.

CAVALHEIRO, Edgard. Monteiro Lobato. Vida e obra. vol I e II. São Paulo: Companhia Editora Nacional, 1955.

CECANTTINI, João Luís; PEREIRA, Rony Farto. Narrativas juvenis. Assis: Editora UNESP, 2008. 
CHEYFITZ, Eric. The poetics of imperialism: translation and colonization from The tempest to Tarzan. Philadelphia: University of Pennsylvania Press, 1991.

CALDAS AULETE. Diccionario contemporaneo da língua portugueza. 2 ed. Lisboa: Parceria Antonio Maria Pereira, 1925.

CARONE, Edgar. A segunda república (1930-1937). São Paulo: Difel, 1978.

CAVALHEIRO, Edgard. Monteiro Lobato, vida e obra. São Paulo: Companhia Editora Nacional, 1955.

COELHO, Nelly Novaes. Literatura Infanitl: história teoria e análise. São Paulo/Brasília: Edições Quiron, 1981.

CORÇÃO, Gustavo. In: MARITAIN Jacques. Reflexões sobre os Estados Unidos (Trad. Manuel Bandeira). Rio de Janeiro: Editora Fundo de Cultura, 1959.

CRYSTAL, David. The Cambridge encyclopedia of the English language. 3 ed. Cambridge: Cambridge University Press, 1997.

CUNHA, Celso Ferreira da. Gramática da língua portuguesa. Rio de Janeiro: FENAME, 1980.

DE CICCO, Cláudio. Hollywood na cultura brasileira. São Paulo: Convívio, 1979.

D'HULST, Lieven. "Why and how to write translation histories?" In: MILTON, John (Org.). Emerging views on translation history in Brazil. Crop. n. 6. São Paulo: Humanitas, 2001. p.21-32.

DOURADO, Autran. Prefácio. In:RANGEL, GODOFREDO. Falange gloriosa. Rio de Janeiro: Casa Rui Barbosa, 2000.

DUTRA, Eliana de Freitas. Cultura. In: SCWARCZ, Lilia Moritz (Org.) A abertura para o mundo 1889-1930. vol 4. Rio de Janeiro: Fundación Maprfre, 2013.

DULLES, John W. F. Getúlio Vargas. Rio de Janeiro: Renes, 1967.

EL FAR, Alessandra. Páginas de sensação. São Paulo: Companhia das Letras, 2004.

EUZÉBIO, Eliane. O poder das ideias. As traduções com objetivos políticos de Carlos Lacerda. Dissertação de mestrado. Departamento de Letras Modernas. FFLCH-USP. São Paulo 2007.

EVEN-ZOHAR, Itamar. The position of translated literature within the literary polysystem. In: LEFEVERE, André. Translation, rewriting and the manipulation of literary fame. London \& New York: Routledge, 1992. 
FIGUEIREDO, Eurídice. Identidade nacional e identidade cultural. In:

Conceitos de literatura e cultura. Juiz de Fora: UFJF/EdUFF, 2005.

IVO, Lêdo, Confissões de um poeta. 2 ed. São Paulo: Global, 1985.

GENETTE, Gérard. Pratextos editoriais. (Trad. Álvaro Faleiros). São Paulo: Ateliê Editorial, 2009.

GÓES, Fernando. Maravilhas do conto brasileiro. São Paulo: Cultrix, 1958.

GUIMARÃES, Hélio S. Os Leitores de Machado de Assis. São Paulo: Nankin, 2004.

GUIRAUD, Pierre. A estilística. São Paulo: Mestre Jou, 1970.

HALLEWELL, Laurence. O livro no Brasil. São Paulo: Edusp, 1985.

HERMANS, Theo. The translator's voice in translated narrative. Target. 8:1. 1996. John Benjamins B. V., Amsterdam. pp. 24-48.

HOUAISS, Antonio. Dicionário da língua portuguesa. Rio de Janeiro: Objetiva, 2001. Dicionário de sinônimos e antônimos. Rio de Janeiro: Objetiva, 2003.

do Livro, 1967. . Elementos de bibliologia. vol 2. Rio de Janeiro: Instituto Nacional

KOSHIYAMA, Alice Mitika. Monteiro Lobato: intelectual, empresário, editor. São Paulo: T. A. Queiroz, 1982.

LACASSIN, Francis. Tarzan ou le chevalier crispé. Paris: Union Générle d'Éditions, 1971.

LAJOLO, Marisa; ZILBERMAN, Regina. A formação da leitura no Brasil. 3 ed. São Paulo: Ática, 1996. . O preço da leitura. 1 ed. São Paulo: Ática, 2001.

2014. (Org.). Monteiro Lobato, livro a livro: obra adulta. São Paulo: Unesp,

LIMA, Yone Soares de. A ilustração na produção literária de São Paulo. São Paulo: IEB, 1985.

LEFEVERE, André. Translating literature. New York: The Modern Language Association of America, 1992.

LOBATO, Monteiro. A barca de Gleyre. vol 1. São Paulo: Brasiliense, 1957 a. A barca de Gleyre. vol 2. São Paulo: Brasiliense, 1957 b. 
. Mundo da lua e miscelânea. São Paulo: Brasiliense, 1957c.

. Ideias de Jeca Tatu. 8 ed. São Paulo: Brasiliense, 1957d.

. Cartas escolhidas. 8 ed. São Paulo: Brasiliense 1957e.

. Conferências artigos e crônicas. São Paulo: Brasiliense, 1972.

LUFT, Celso Pedro. Dicionário prático de regência verbal. São Paulo: Ática, 2003.

MACHADO, Irene. Gêneros discursivos. In: Beth BRAIT (Org.). Bakhtin, conceitoschave. São Paulo: Contexto, 2005.

MAINGUENEAU, Dominique. Pragmática para o discurso literário. São Paulo: Martins Fontes, 1996.

MARTINEZ, Sabrina Lopes. Monteiro Lobato: Tradutor ou adaptador. Tradução em Revista, Rio de Janeiro, n. 4, p.1-17, 2008. Disponível em:

http://www.maxwell.lambda.ele.pucio.br/trad_em_revista.php?strSecao=input. Acesso em02/04/2014.

MARTINS, Wilson. História da inteligência brasileira. vol. VI. São Paulo: Cultrix, 1978.

Queiroz Filho: 1996.

. História da inteligência brasileira. 2 ed. vol VII. São Paulo: T. A.

MÁXIMO, Gustavo. Duas Personagens em uma Emília nas Traduções de Monteiro Lobato. Dissertação de Mestrado, IEL - UNICAMP, São Paulo, 2004.

MEIRELES, Cecília. Problemas da literatura infantil. Rio de Janeiro: Nova Fronteira, 1985.

Queiroz, 1996.

. História da inteligência brasileira. vol VII. 2 ed. São Paulo: T A

MENDES, Denise Rezende. Monteiro Lobato o tradutor. Dissertação de mestrado.

Departamento de Letras Estrangeiras Modernas da Universidade Federal de

Juiz de Fora, 2002.

MICELI, Sergio. Intelectuais à brasileira. São Paulo: Companhia das Letras, 2001.

MILTON, John. O poder da tradução. São Paulo: Ars Poética, 1993.

O clube do livro e a tradução. Bauru: EDUSC, 2002.

. Monteiro Lobato e tradução: "um país se faz com homens e livros".

DELTA - Documentação de Estudos em Teórica de Linguística e Aplicada, São Paulo, n. 19, p. 117, 2003. Disponível em: 
http://www.scielo.br/scielo.php?script=sci_text\&pid=S0102-44502003000300008 Acesso em 02/04/2014.

. The importance of economic factors in translation publication: an example from Brazil. IN: PYM, Anthony; SHLESINGER Miriam; SIMEONI, Daniel (Org.). Beyond descriptive translation studies: investigations in homage to Gideon Toury. Amsterdam Philadelphia: John Benjamins Publishing Company, 2008.

."The resistant political translations of Monteiro Lobato. Massachusetts review, 27 (3), p. 486-511, 2006.

MOISÉS, Massaud. A criação literária: prosa. 15 ed. São Paulo: Cultrix, 1967.

MORAES, Marcos Antonio de (Org.). Correspondência: Mário de Andrade \& Manuel Bandeira. São Paulo: Edusp, 2000.

MORIN, Edgar. Cultura de massa no século XX. Rio de Janeiro: Forense, 1967.

MOURA, Agenor Soares de. À margem das traduções. São Paulo: ARX, 2003.

NODELMAN, Perry. Words about pictures. Athens, Georgia: University of Georgia Press, 1988.

NOWINSKA, Madaglena. Tradução e sensibilidade: Die Judenbuche de Annette von Droste-Hülsshoff e suas traduções. São Paulo 2012. Tese (Doutorado em Letras). Faculdade de Filosofia, Letras e Ciências Humanas da Universidade de São Paulo.

OLYMPIO. José. Anuário literário brasileiro. Rio de Janeiro: Pongetti, 1937.

PAES, José Paulo. Tradução, a ponte necessária. São Paulo: Ática: 1990.

PAGANO, Adriana Silvina. "As pesquisas historiográficas em tradução". In: PAGANO A. (Org.). Metodologias de pesquisa em tradução. Belo Horizonte: FALE-UFMG, 2001.

PALOTTA, Míriam Giberti Páttaro. Reflexões sobre a prática da tradução para Monteiro Lobato: análise da obra Fábulas. XI Congresso Internacional da ABRALIC Tessituras, Interações, Convergências 13 a 17 de julho de 2008 USP - São Paulo.

PAIXÃO, Fernando (Ed.). Momentos do livro no Brasil. São Paulo: Ática, 1997. PÉCAUT, Daniel. Intelectuais e classes dirigentes no Brasil. São Paulo: Ática, 1998.

PEIXOTO, Afrânio. In: BEERS, Clifford W. Um espírito que achou a si mesmo (Trad. Manuel Bandeira). São Paulo: Companhia Editora Nacional, 1934.

PERRONE-MOISÉS, Leyla. Altas literaturas. São Paulo: Companhia das Letras, 1998. POWERS, Alan. Era uma vez uma capa. (Trad. Otacílio NUNES). São Paulo: Cosac Naify, 2008. 
RAMOS, Vera Lúcia. A sivilização-civilização de Huckberry Finn: uma proposta de tradução. Dissertação para obtenção de título de mestre. 2008. Faculdade de Filosofia, Letras e Ciências Humanas. Universidade de São Paulo.

RENAULT, Abgar. Notas à margem de algumas traduções de Manuel Bandeira. IN: Homenagem a Manuel Bandeira. São Paulo: Universidade Federal Fluminense e METAL LEVE, 1986.

RODALE, J. I. The synonym finder. New York - Boston: Warner Books, 1986.

RÓNAI, Paulo. A tradução vivida. Rio de Janeiro: Nova Fronteira, 1981.

SALIBA. Elias Thomé. Cultura. In: SCWARCZ, Lilia Moritz (Org.) A abertura para o mundo 1889-1930. vol 3. Rio de Janeiro: Fundación Maprfre, 2012.

SANT'ANNA MARTINS, Nilce. Introdução à estilística. 3 ed. São Paulo: T. A. Queiroz, 2003.

SANTOS, Agenor Soares dos. Guia prático de tradução inglesa. São Paulo: Cultrix, 1983.

SANTOS, Katia Regiane Gonçalves dos. Pollyanna vista pelos olhos de Monteiro Lobato. TradTerm, 17, São Paulo, 2010, p. 187-193.

SEVCENKO. Nicolau. A capital irradiante: técnica, ritmos e ritos do Rio. IN: ; NOVAIS, Fernando A. (Org.). História da vida privada no Brasil . vol

3. São Paulo: Companhia das Letras, 1998.

SILVA, Márcia Cabral da. Uma história da formação do leitor no Brasil. Rio de Janeiro: EdUERJ, 2009.

SILVA, Diamantino da; LOSSO, Umberto; SAKAMOTO, Kendi. No tempo das matinês. Emoções no cinema de bairro. São Paulo: Laços, 2007.

SILVEIRA, Brenno. A arte de traduzir. São Paulo: Melhoramentos, 1954.

SIMON, Iumna Maria (Org.). Território da tradução. Remate de males. n. 4. Revista do Departamento de Teoria Literária. IEL - UNICAMP/FUNCAMP. Campinas: 1984.

TÁCITO, Hilário. Prefácio. IN; RANGEL, Godofredo. Vida ociosa. Rio de Janeiro: Casa da Palavra, 2000.

The New Oxford English Dictionary. Oxford: Clarendon Press, 1998.

TODOROV, Tzvetan. As estruturas narrativas (Trad. Leyla Perrone-Moisés). São Paulo: Perspectiva, 1970.

TOLEDO, Maria Rita de A. A indústria de livros, a materialidade do impresso e o campo educacional: reflexões sobre a organização do acervo histórico da Companhia 
Editora Nacional.

http://www.sbhe.org.br/novo/congressos/cbhe3/Documentos/Individ/Eixo1/019.pdf.

Acesso 04/09/2012.

TOOGE, Marly, D’Amaro B. Traduzindo o Brasil. São Paulo: Humanitas, 2011.

TOURY, Gideon. The nature and role of norms in translation. In: VENUTTI, Lawrence (Org.) The translation studies reader. 3 ed. London \& New York: Routledge, 2003.

. Descriptive translation studies and beyond. Benjamins Translation

Library vol 4. Amsterdam/Philadelphia: John Benjamins Publishing Company, 1995.

TYMOCZKO, Maria. Connecting the two infinite orders: research methods in translation studies. In: HERMANS, Theo (Org.) Transcutlural transgressions: research models in translation studies II. Manchester: St. Jerome, 2002.

1999.

. Translation in a postcolonial context. Manchester: St Jerome,

VERÍSSIMO, Érico. Um certo Henrique Bertaso. São Paulo: Companhia das Letras, 2005.

. Solo de clarineta. vol 1. Porto Alegre: Globo, 1987.

VIEIRA, Adriana Silene. Monteiro Lobato translator (Trad. John Milton). In: MILTON, John (ed.). Emerging views on translation history in Brazil. Crop. n. 6. p.143-169. São Paulo: Humanitas 2001.

VIEIRA, Else R. P. Por uma teoria pós-moderna da tradução. Belo Horizonte, 1992. Tese (Doutorado em Letras) - Faculdade de Artes e Letras. Universidade Federal de Minas Gerais.

WANDERLEY, Jorge. A tradução do poema entre poetas do Modernismo: Bandeira, Guilherme de Almeida, Abgar Renault, PUC-RJ, 1988. Tese de doutoramento.

WILLIAMS, Jenny; CHESTERMANN, Andrew. The map: a beginner's guide to doing research in translation studies. Manchester, UK \& Northampton, MA: St Jerome, 2002.

WYLER, Lia. Línguas, poetas e bacharéis: uma crônica da tradução no Brasil. Rio de Janeiro: Rocco, 2003.

116.

O que é censura? D.E.L.T.A., n. 19, especial. 2005. PUC-SP.pp. 109- 


\section{BIBLIOGRAFIA COMPLEMENTAR}

ANDRADE, Mário de. Aspectos da literatura brasileira. São Paulo: Martins/INL, 1972.

BANDEIRA, Manuel. Poesia e prosa. 1 ed. vol I. Rio de Janeiro: José Aguilar, 1958 a. . Poesia e prosa. 1 ed. vol II. Rio de Janeiro: José Aguilar, 1958 b. . Estrêla da vida inteira. 1 ed. Rio de Janeiro: José Olyimpio, $1966 b$. . Andorinha, andorinha. São Paulo: Círculo do Livro, 1978. . Crônicas da província do Brasil. São Paulo: Cosac Naify, 2008.

BASSNETT, Susan. "Researching translation studies". In: BUSH, Peter; MALMKJAER, Kirsten. Rimbaud's rainbow. Amsterdam \& Philadelphia: John Benjamins, 1998a. . Comparative literature. 4 ed. Great-Britain: Blackwell, 1998 b.

CANDIDO, Antonio. Literatura e sociedade. Rio de Janeiro: Ouro sobre Azul, 2010. . A educação pela noite. 2 ed. São Paulo: Ática, 1989.

CARA, Salete de Almeida. Manuel Bandeira. São Paulo: Nova Cultural, 1990.

CEVASCO, M. Elisa. 10 lições sobre estudos culturais. São Paulo: Boitempo, 2003.

DINIZ JUNIOR, Ebal Martins. Atravessando o espelho: transfigurando o autor na tradução literária. Tese de doutoramento. 2002. Faculdade de Filosofia, Letras e Ciências Humanas da Universidade de São Paulo.

KRAKAUER, Siegfried. O ornamento da massa. São Paulo: Cosac Naif, 2009.

LEFEVERE, André. Translation, rewriting and the manipulation of literary fame. London \& New York: Routledge, 1992a. . Translating literature: practice and theory in a comparative context. New York: The Modern Language Association of America, 1992b.

NEGREIROS, Gil Roberto Costa. Marcas de oralidade na poesia de Manuel Bandeira. Paulistana, 2009.

PELEGRINO, Laureano. Tradutores e editores: resistência, restrições, relações. Dissertação de mestrado. 2002. FFLCH-USP.

PYM, Anthony. Method in translation history. Manchester: St. Jerome, 1998. 
VENUTI, Lawrence (Org.). Translation studies reader. London \& New York: Routledge, 2003.

. Translatior's invisibility. London \& New York: Routledge, 2002.

ZANGER, Jules. Dorothy and Tarzan: notes towards a theory of national phantasy. IN: LANGFORD, Michelle. Contours of the Fantastic: Selected Essays from the Eighth International. Wesport, CT: Greenwood Press, 1990.

ZUMTHOR, Paul. Performance, recepção e leitura. São Paulo: Cosac Naif, 2007. 
